FACULDADE DE DIREITO

\author{
ANA MARIA PEDREIRA
}

\title{
RESPONSABILIDADE DO ESTADO POR OMISSÃO - \\ Prevenção, Precaução e Controle como meios de evitar a ocorrência do dano
}

São Paulo

2013 


\section{RESPONSABILIDADE DO ESTADO POR OMISSÃO - Prevenção, Precaução e Controle como meios de evitar a ocorrência do dano}

Dissertação de mestrado apresentada ao Departamento de Direito do Estado, para obtenção do título de Mestre em Direito.

Área de concentração: Direito do Estado - Direito Administrativo

Orientador: Professor Doutor Edmir Netto de Araújo 
Serviço de Biblioteca e Documentação Faculdade de Direito da Universidade de São Paulo

\section{Pedreira, Ana Maria.}

P399r Responsabilidade do Estado por omissão: prevenção, precaução e controle como meios de evitar a ocorrência do dano / Ana Maria Pedreira. - - São Paulo: USP / Faculdade de Direito, 2013.

$254 \mathrm{f}$.

Orientador: Prof. Dr. Edmir Netto de Araújo.

Dissertação (Mestrado), Universidade de São Paulo, USP, Programa de Pós-Graduação em Direito, 2013.

1. Responsabilidade do Estado. 2. Omissão. 3. Controle Administrativo. 4. Administração Pública. I. Araújo, Edmir Netto de. II. Universidade de São Paulo, Faculdade de Direito, Programa de Pós-Graduação em Direito. III. Título. 


\section{AGRADECIMENTOS}

Ao querido Professor Dr. Edmir Netto de Araújo, depositário da minha eterna gratidão, não apenas pela orientação firme e serena, sabendo sempre transformar a relação entre orientador e orientado em amizade sincera, mas pelo carinho que dispensa a todos os seus alunos sem distinção.

Ao estimado Professor Dr. José Cretella Neto, pelo exemplo de dedicação, lealdade e disciplina, assim como pela confiança e incentivo incessantes. Com sua generosidade, suas críticas sinceras e construtivas, me ensinou muito do que sei.

Ao querido Padre Leocir Pessini, para quem não existe obstáculo intransponível e que, com sua sabedoria, sempre encontra as palavras certas para acalmar um coração angustiado.

Ao Professor Mario Miranda Filho, mestre e filósofo que me guia pelo fascinante mundo da Filosofia, pela contribuição inestimável para a elaboração desta dissertação.

Ao meu filho Lucas, razão de tudo, luz que ilumina minha vida e que, apesar da tenra idade, sabe me compreender.

Aos meus amigos queridos Irene Patricia Nohara, João Honório de Souza Franco e todos aqueles que me apoiam e me incentivam a continuar. A amizade sincera é o maior tesouro do ser humano.

Agradeço a Deus por todas as bênçãos, mas principalmente pela dádiva de tê-los em minha vida. 


\section{FOLHA DE APROVAÇÃ̃O}

\section{Ana Maria Pedreira}

\section{RESPONSABILIDADE DO ESTADO POR OMISSÃO - Prevenção, Precaução e}

Controle como meios de evitar a ocorrência do dano

Dissertação apresentada à Faculdade de Direito da Universidade de São Paulo para obtenção do título de Mestre em Direito.

Área de Concentração: Direito do Estado - Direito Administrativo

Aprovada em:

\section{Banca Examinadora}

Prof. Dr. Edmir Netto de Araújo

Instituição: Assinatura:

Prof. Dr.

Instituição: Assinatura:

Prof. Dr.

Instituição: Assinatura:

Prof. Dr.

Instituição: Assinatura:

Prof. Dr.

Instituição: Assinatura: 


\section{RESUMO}

\section{PEDREIRA, Ana Maria. RESPONSABILIDADE DO ESTADO POR OMISSÃO -}

Prevenção, Precaução e Controle como meios de evitar a ocorrência do dano. 2013. 254f. Dissertação (Mestrado) - Faculdade de Direito, Universidade de São Paulo, São Paulo, 2013.

O tema Responsabilidade do Estado é, seguramente, um dos mais estimulantes e de grande atualidade dentro do universo da ciência do Direito, principalmente porque envolve inúmeros aspectos de abordagem. Nos limites desta temática de tão ampla magnitude que abarca não apenas a responsabilidade da Administração como, também, a do Estado Juiz e a do Estado Legislador, a responsabilidade por comportamentos omissivos atrai e desperta o interesse dos estudiosos pelas diversas ponderações que admite. A presente dissertação, com o intuito de impedir que haja confusão conceitual e apreciação superficial sobre o assunto, se limitará à análise da responsabilidade da Administração por comportamentos omissivos, com vistas à aplicação efetiva dos princípios da prevenção e da precaução como uma inovadora possibilidade de se evitar a ocorrência do dano. Também o Controle da Administração Pública, descortinado no capítulo quatro, sugere tal mecanismo como instrumento efetivo e eficaz, o qual encontra-se à disposição da Administração Pública para ser utilizado com o objetivo de evitar que o terceiro suporte as consequências do dano sem a devida reparação, obrigando o Estado ao cumprimento de seu dever de indenizar. Na realidade, o debate acerca da responsabilidade da Administração por comportamentos omissivos traz consigo amplo campo de confrontação das diferentes teorias, sobretudo no que diz respeito à aplicação da teoria objetiva de responsabilização que, a cada dia, vem alcançando maior acolhida no ordenamento jurídico brasileiro. Trata-se, contudo, de uma apreciação no âmbito da responsabilidade extracontratual do Estado, visto que não se pretende aqui envolver o estudo das atividades estatais de natureza contratuais. Assim, com relação às considerações preliminares, para melhor compreensão desse desafio, esta dissertação será dividida em quatro capítulos. O primeiro deles cuidará de apresentar breves considerações gerais sobre a responsabilidade do Estado, inclusive sua evolução histórica. No segundo capítulo, fazer-se-á uma análise específica e limitada à responsabilidade do Estado por comportamentos omissivos. No terceiro capítulo a abordagem recairá sobre a aplicação do princípio da prevenção e da precaução à responsabilidade do Estado como forma de evitar a ocorrência de danos. E por derradeiro procurar-se-á esmiuçar o Controle da Administração Pública, apontando os instrumentos nele contidos como forma de impedir a ocorrência de danos e, consequentemente, desonerando o Estado da obrigação de indenizar as vítimas, permitindolhe redirecionar os recursos despendidos em indenização, em políticas públicas e medidas de melhorias dos serviços públicos.

Palavras-chave: Responsabilidade do Estado. Omissão. Controle da Administração. Princípio da Prevenção. Princípio da Precaução. 


\title{
RESUME
}

\author{
PEDREIRA, Ana Maria. LA RESPONSABILITÉ DE L'ÉTAT POUR OMISSION - \\ Prévention, Précaution et Contrôle comme un moyen d'eviter l'Apparition de \\ dommages. 2013. 254f. Dissertation (Maîtrise) - Faculté de Droit, Université de São Paulo, \\ São Paulo, 2013.
}

Le sujet de la Responsabilité de l'Etat est certainement l'un de plus passionnants et très actuel dans l'univers de la science du Droit, surtout parce qu'il implique de nombreux aspects d'approche. Dans les limites de cette thématique d'une telle ampleur si vaste qui englobe non seulement la responsabilité de la Gestion de même que l'État Juge et l'État Législateur, la responsabilité des conduites d'omission attire et suscite l'intérêt des chercheurs par les diverses considérations qui admet. La presente thèse, afin d'éviter toute confusion conceptuelle et appréciation superficielle sur ce sujet, se limitera à l'analyse de la responsabilité de la Gestion par conduite par omission, visant à l'application effective des principes de prévention et de précaution comme une opportunité novatrice pour éviter la survenance de dommages. De plus, le Contrôle de la Gestion Publique, dévoilé sur le chapitre quatre, suggère tel mécanisme comme un outil effectif et efficace, qui se trouve à la disposition de la Gestion Publique pour être utilisé afin de prévenir que le troisième supporte les conséquences des dommages sans la due réparation, ce qui oblige l'Etat à se conformer à son obligation d'indemniser.En effet, le débat sur la responsabilité de la Gestion de comportements par omissions, apporte en soi un vaste domaine de la confrontation de différentes théories, en particulier en ce qui concerne l'application de la théorie objective de responsabilisation qui, jour après jour, atteint une plus grande acceptation dans le système juridique brésilien .Il s'agit, cependant, d'un examen en vertu de la responsabilité extracontractuelle de l'Etat, car il n'est pas prévu ici impliquer l'étude des activités gouvernementales de nature contractuelle.Donc, en ce qui concerne les considérations préliminaires, afin de mieux comprendre ce défi, cette thèse est divisé en quatre chapitres. Le premier aura soin de présenter de brèves remarques générales sur la responsabilité de l'Etat, y compris son évolution historique. Dans le deuxième chapitre, on fera une analyse spécifique et limitée à la responsabilité de l'Etat par des comportements d'omissions. Le troisième chapitre parlera sur l'application du principe de prévention et de précaution appliqué à la responsabilité de l'État en tant que moyen de prévenir les dommages de se produire. Et finalment on cherchera à scruter le Contrôle de la Gestion Publique, en soulignant les instruments qui y sont contenues comme un moyen de prévenir les dommages de se produire et ainsi soulager l'obligation de l'État d'indemniser les victimes, leur permettant de réorienter les ressources dépensées en dommages et intérêts politiques publiques et des mesures d'amélioration des services publics.

Mot-clé: La Responsabilité de l'Etat. Omission. Contrôle de la Gestion. Principe de la Prévention. Principe de la Précaution. 


\section{SUMÁRIO}

INTRODUÇÃO .............................................................................................................................................................10

I ASPECTOS GERAIS SOBRE A RESPONSABILIDADE DO ESTADO ..............................15

1.1 DEFINIÇÃO DE RESPONSABILIDADE DO ESTADO...........................................................15

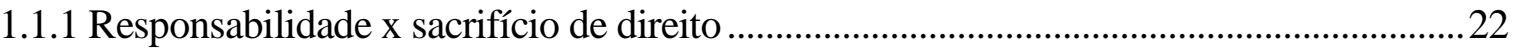

1.2 TEORIAS SOBRE A RESPONSABILIDADE DO ESTADO.................................................24

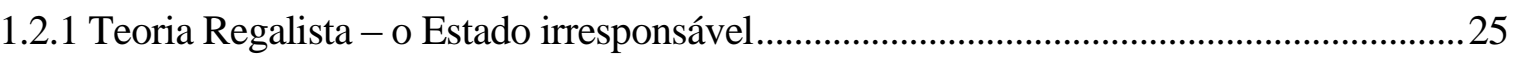

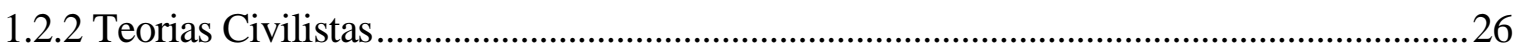

1.2.2.1. Teoria dos atos de impérios e de gestão ...................................................................266

1.2.2.2 Teoria da culpa civil ou da responsabilidade subjetiva .........................................22

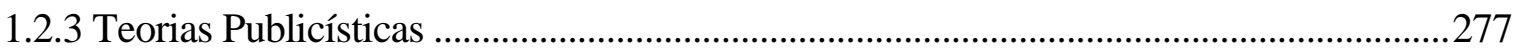

1.2.3.1 Teoria da culpa administrativa, culpa anônima ou culpa do serviço......................277

1.2.1.2 Teoria da responsabilidade objetiva ou teoria do risco. .........................................2.28

1.3 ASPECTOS HISTÓRICOS ...............................................................................................................355

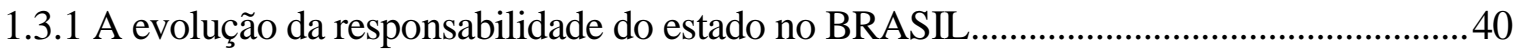

1.4 RESPONSABILIDADE EXTRACONTRATUAL DO ESTADO ..........................................45

1.4.1 Elementos para a caracterização da responsabilidade estatal ...............................................45

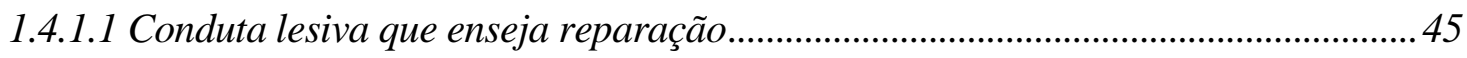

1.4.1.2 A responsabilidade do Estado por atos lícitos ........................................................466

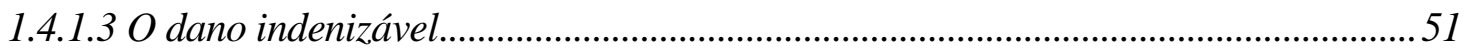

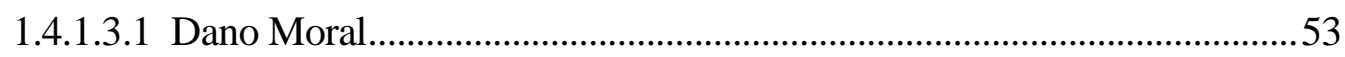

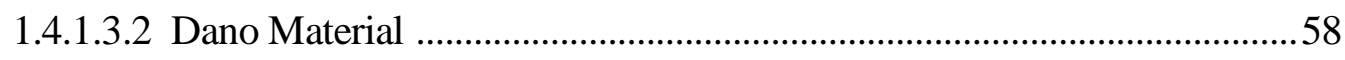

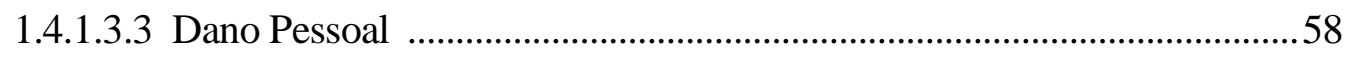

1.4.1.3.4 Dano oriundo de relações de consumo ....................................................59

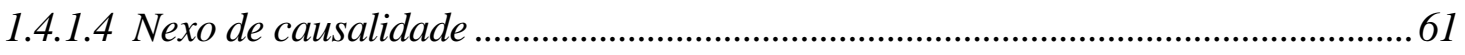

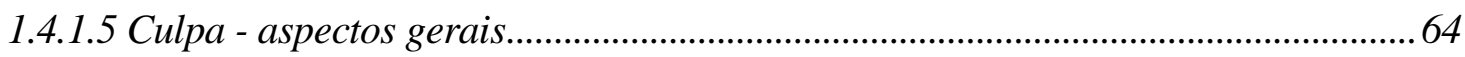

1.5 FUNDAMENTOS DA RESPONSABILIZAÇÃO DO ESTADO........................................688

1.6 CAUSAS EXCLUDENTES E ATENUANTES DA RESPONSABILIDADE ESTATAL 70

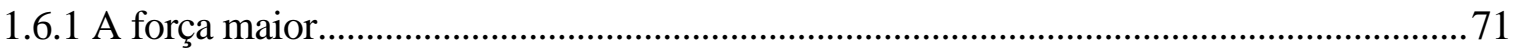

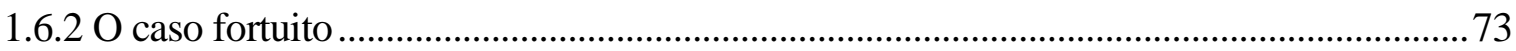

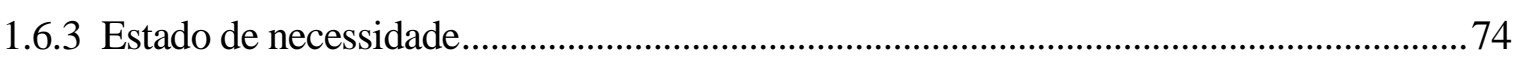

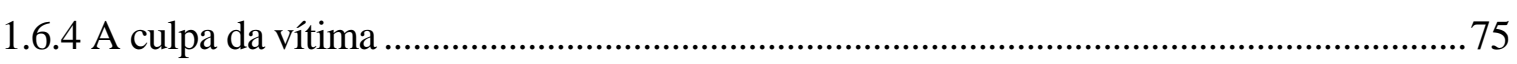

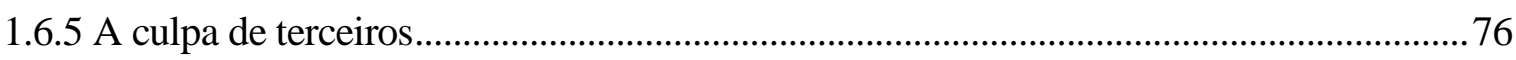

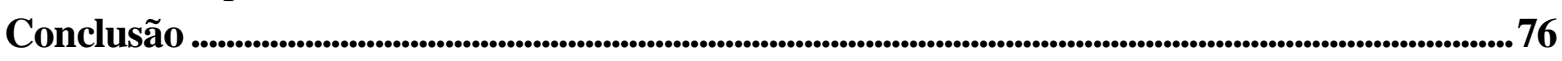

II A RESPONSABILIDADE DO ESTADO POR OMISSÃO .............................................................79

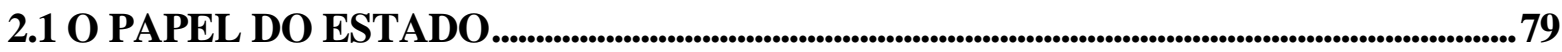

2.2 DANOS CAUSADOS PELA OMISSÃO DO ESTADO.................................................................86

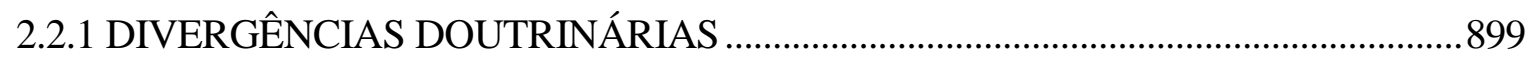

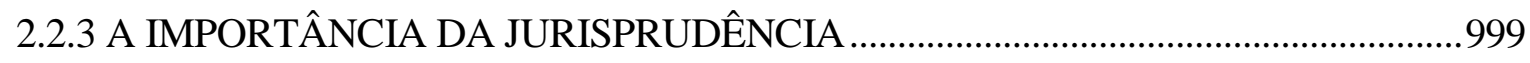




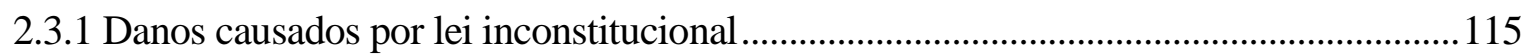

2.3.2 Danos Causados por lei constitucionalmente perfeita ..................................................116

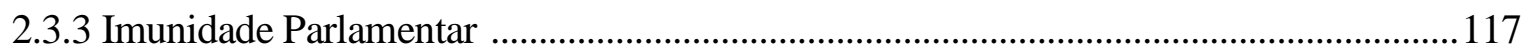

2.4. RESPONSABILIDADE POR OMISSÃO NA ATIVIDADE JURISDICIONAL .......118

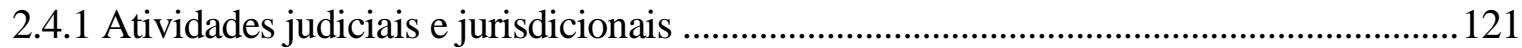

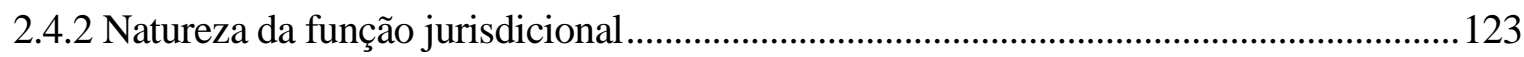

2.4.3 Atos jurisdicionais: responsabilidade pessoal do juiz....................................................123

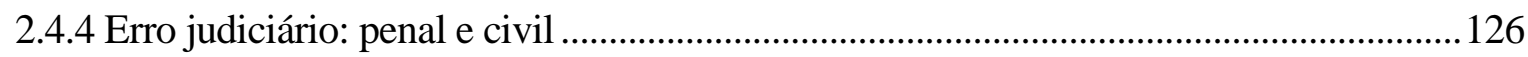

2.5 A RESPONSABILIDADE DO AGENTE PÚBLICO ....................................................................... 128

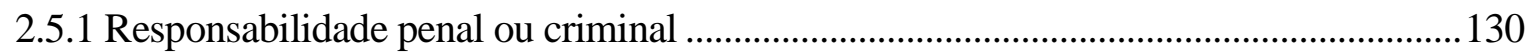

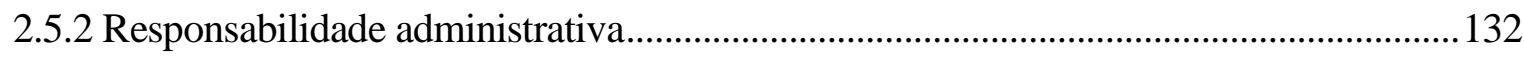

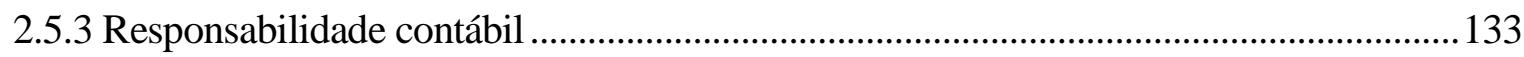

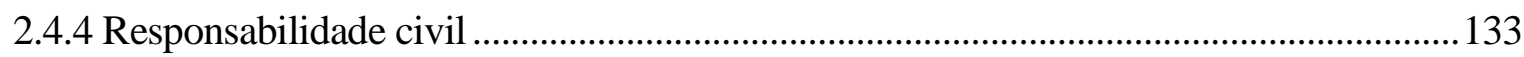

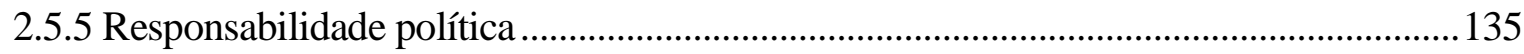

2.5.6 Responsabilidade pela prática de ato de improbidade administrativa ...............................136

2.6 RESPONSABILIDADE INOMINADA DO ESTADO ..........................................................137

2.6.1 Danos decorrentes de tempestades, enchentes e desabamentos.....................................1388

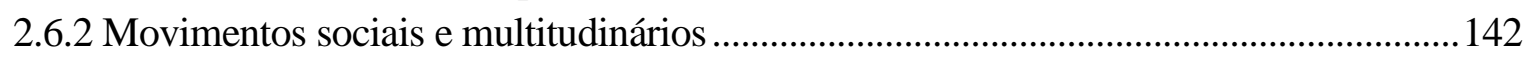

2.6.3 Fatos de guerra. Movimentos revolucionários e movimentos terroristas..........................146

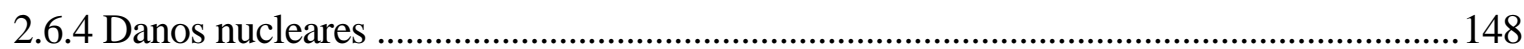

2.7 DA REPARAÇÃO DO DANO ..................................................................................................149

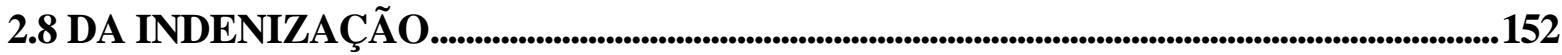

2.9 DENUNCIAÇÃO DA LIDE $\ldots . . \ldots \ldots \ldots \ldots$

2.10 AÇÃO REGRESSIVA CONTRA O CAUSADOR DO DANO .............................................159

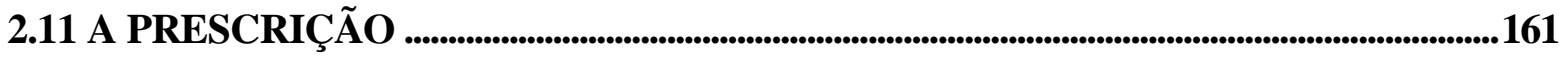

Conclusão

III PRINCÍPIO DA PREVENÇÃO E DA PRECAUÇÃO APLICADO À RESPONSABILIDADE DO ESTADO POR OMISSÃO.........................................................................166

3.1 DEFINIÇÃO E CLASSIFICAÇÃO DE PRINCÍPIOS.....................................................................166

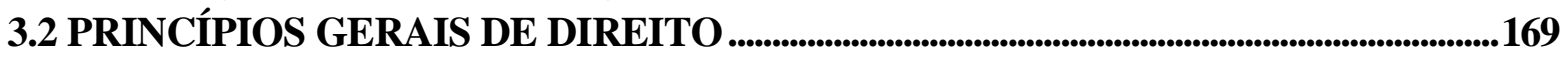

3.3 DISTINÇÃO ENTRE NORMAS, PRINCÍPIOS E REGRAS.................................................171

3.4 PRINCÍPIOS DO DIREITO ADMINISTRATIVO .......................................................................175

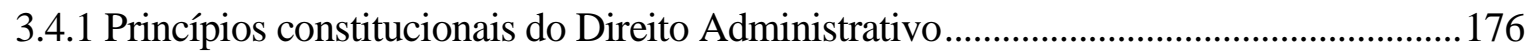

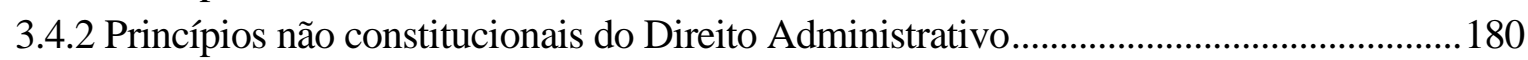

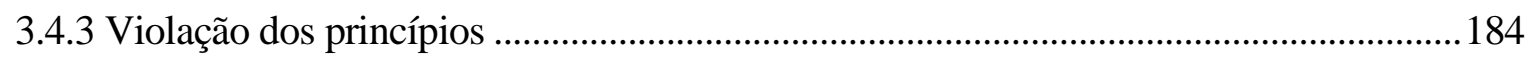

3.5 PRINCIPIO DA PRECAUÇÃO: UM PRINCÍPIO JURÍDICO ................................................186

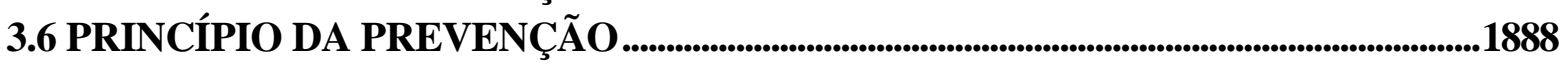

3.7 PRINCÍPIO DA PRECAUÇÃO X PREVENÇÃO DE RISCOS..........................................189

3.8 A EFETIVIDADE DO PRINCÍPIO DA PRECAUÇÃO...............................................................190

3.9 APLICAÇÃO DA PRECAUÇÃO E PREVENÇÃO NA ATIVIDADE ESTATAL...192

Conclusão 
IV O CONTROLE COMO MECANISMO PARA EVITAR O DANO .....................................196

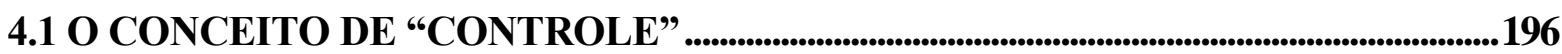

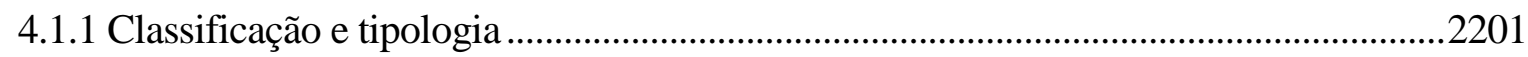

4.2 O CONTROLE INTERNO DA ADMINISTRAÇÃO ...............................................................204

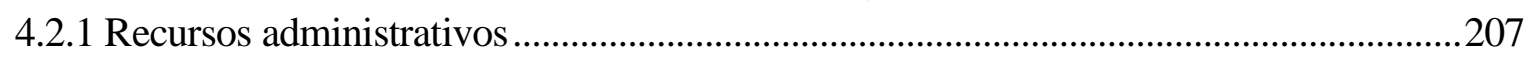

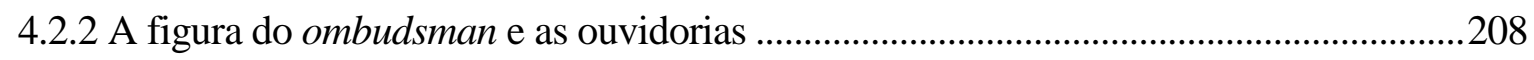

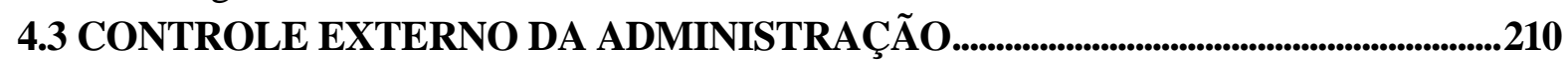

4.3.1 Controle da administração pelo Ministério Público..........................................................213

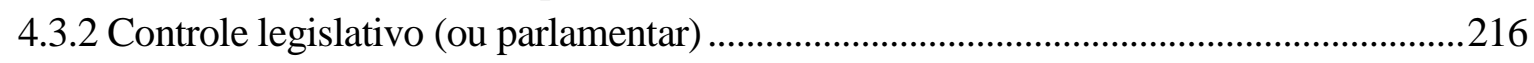

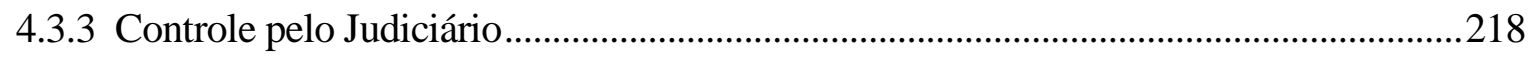

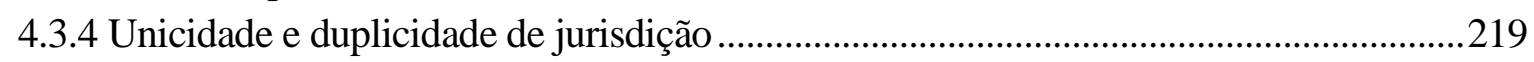

4.3.5 O sistema adotado no Brasil e suas controvérsias..............................................................22

4.3.6 O controle político........................................................................................................22

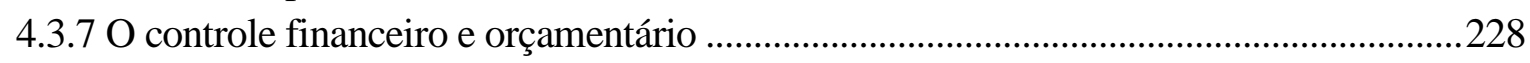

4.4 INSTRUMENTOS OU MEIOS DE CONTROLE .....................................................................229

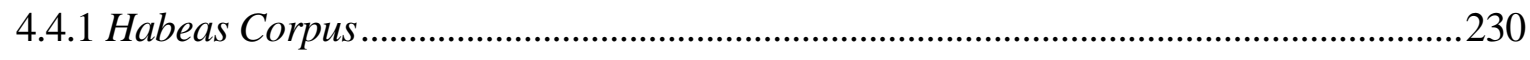

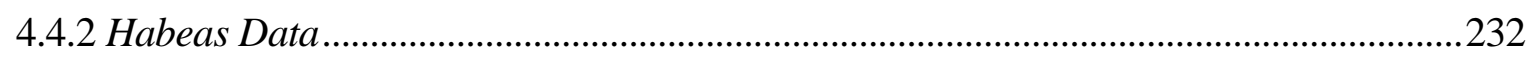

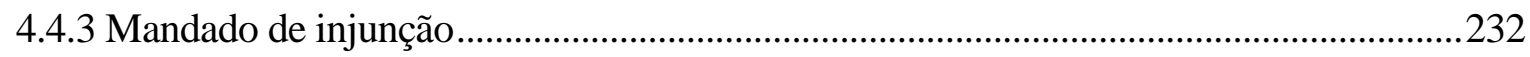

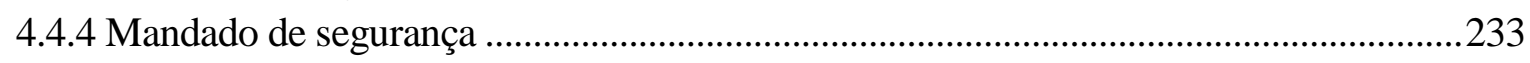

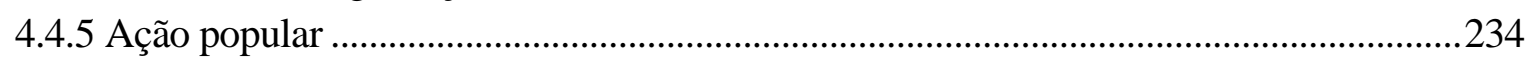

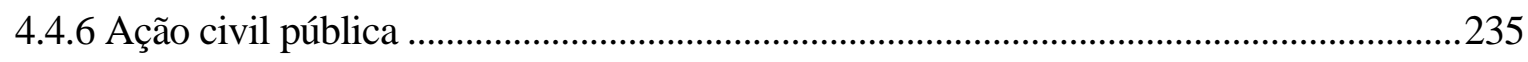

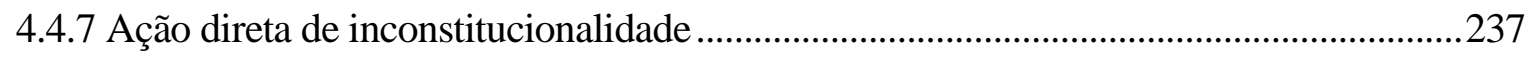

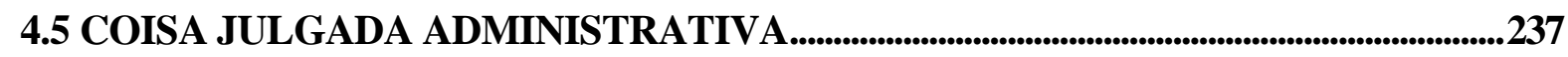

4.6 PRESCRIÇÃO E DECADÊNCIA ............................................................................................................238

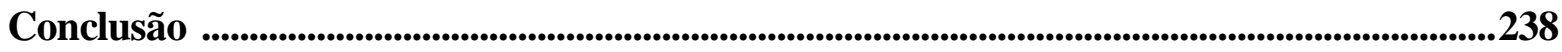

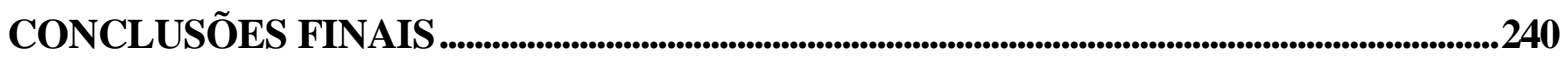

REFERÊNCIAS BIBLIOGRÁFICAS.......................................................................................................2247 


\section{INTRODUÇÃO}

Hodiernamente, a responsabilidade do Estado é acatada na maioria dos Estados modernos, tal como se observa pela análise doutrinária, jurisprudencial e pelas legislações dos povos civilizados. De acordo com esse consenso, o Estado é obrigado a promover a reparação dos danos causados em decorrência da atividade estatal, provocados por seus agentes ou simplesmente por sua inércia.

A vida em sociedade está regulada por normas que buscam atingir o equilíbrio e a harmonia social, afastando as arbitrariedades que podem ocasionar prejuízos aos indivíduos que integram o grupo. A responsabilização imposta aos causadores de danos estabelece um limite à ação humana. Por outro lado, a dinâmica social é um fenômeno que, ao longo do tempo, impõe inúmeras transformações aos diversos institutos jurídicos, a fim de acomodá-los às necessidades do povo, e com relação à responsabilidade estatal não foi diferente.

Ao longo do tempo, o Estado foi mudando suas feições de acordo com as ideologias predominantes; como reação a essas mudanças, ele (Estado) foi se remodelando. Diante de tal realidade, tornou-se imprescindível a elaboração de teorias que melhor se adaptassem àquele contexto fluente.

No primeiro capítulo deste trabalho buscar-se-á introduzir o tema em uma exposição genérica, sem aprofundar nenhum ponto especificamente, apenas demonstrar a trajetória histórica e as noções preliminares sobre a temática, por meio de um trabalho de composição entre as diversas fases da responsabilidade estatal, deixando evidente a estrutura sobre a qual o assunto se firma na atualidade.

A análise da evolução das teorias é importante para que se possa compreender como esse processo se desenrolou. $\mathrm{O}$ desenvolvimento das teorias acerca da responsabilização do Estado pode ser posicionado em três sistemas principais: a) Teoria da Irresponsabilidade ou regaliana; b) Teoria Civilista ou mista; e c) Teorias publicísticas ${ }^{1}$.

O Estado experimentou diversas fases e compreensões sobre o assunto, indo da total irresponsabilidade, evoluindo para a responsabilidade com culpa, civil ou administrativa, transportando-se para a responsabilidade sem culpa, nas modalidades do risco administrativo e do risco integral, e continua evoluindo, segundo prenuncia Celso Antônio Bandeira de

\footnotetext{
${ }^{1}$ ARAUJO, Edmir Netto de. Curso de Direito Administrativo. 5. ed. São Paulo: Saraiva, 2010. p.771.
} 
Mello, para o ponto extremo da responsabilidade, que é o risco social, "cujos termos se promovem mesmo com relação a danos não imputáveis à ação do Poder Público". ${ }^{2}$

A doutrina e a jurisprudência brasileiras ainda não se pacificaram sobre a natureza da responsabilidade do Estado por conduta omissiva. A celeuma gira em torno do questionamento sobre a revogação tácita, ou derrogação, do art. 43 do Código Civil de 2.002, frente ao artigo 37, $\S 6^{\circ}$, da Constituição Federal de 1.988.

De um lado, pulsa o posicionamento que defende a natureza subjetiva da responsabilidade do Estado por omissão, com base no artigo 43 do Novo Código Civil de 2.002 (correspondendo ao artigo 15 do Código Civil de 1.916), restando, portanto, como de natureza objetiva apenas a responsabilidade por condutas comissivas. De outro lado, há aqueles que defendem a aplicação da teoria objetiva, tanto para comportamentos omissivos quanto comissivos, aplicando-se, para ambos, a norma do artigo $37, \S 6^{\circ}$, da $\mathrm{CF} / 88$.

O campo da responsabilidade é amplo, pois não se trata de instituto jurídico exclusivo do Direito Civil, e está inserido no contexto da Teoria Geral do Direito, por isso sofre adaptações conforme aplicado no Direito Público ou Privado. Para sua melhor compreensão, é necessário esmiuçar desde os conceitos mais básicos, e os institutos mais simples, para, então, na medida em que tais conceitos vão ficando claros, se possa avançar para um raciocínio mais elaborado, enfeixando todos os conceitos e apresentando-os como um corpo completo. Nessa linha de raciocínio, a análise deve se iniciar desde a compreensão de fato e ato jurídico, para depois se estender para o campo das relações jurídicas, evoluindo para o terreno das obrigações e se instaurando na seara da responsabilidade.

Nessa toada, tem-se que fato é um pressuposto material da existência de um direito, sendo um fenômeno perceptível, que resulta de uma atividade humana ou de natureza, atuando no mundo exterior. Os fatos podem ser naturais ou jurídicos. O natural é um evento qualquer, dependente ou independente da vontade humana, isto é, com a participação ou não do homem para sua ocorrência. Já o fato jurídico é o evento que marca o início ou o final de relações jurídicas, possibilitando a conservação, modificação ou extinção de direitos.

Os atos jurídicos são definidos como todo comportamento humano que gera efeitos no mundo jurídico, dentre os quais orbitam os atos lícitos e os atos ilícitos. O ato lícito é fonte geradora de obrigação, como o contrato ou a declaração unilateral de vontade, já o ato

\footnotetext{
${ }^{2}$ BANDEIRA DE MELLO, Celso Antônio. Curso de Direito Administrativo. 28. ed. São Paulo: Malheiros, 2011. p. 1007.
} 
ilícito pressupõe a predisposição do agente em prejudicar outrem, a violação de um direito causado por negligência, imprudência ou imperícia.

A finalidade da responsabilização civil é o restabelecimento do equilíbrio violado pelo dano. A fundamentação da responsabilidade civil pode ser subjetiva, hipótese em que deve estar presente o elemento da culpa ou dolo, ou objetiva, hipótese que ocorre quando não há necessidade da prova da culpa, bastando haver dano, conduta e nexo causal entre a lesão experimentada e a atividade estatal.

Nesse contexto, os aspectos históricos são importantes porque lançam enfoque sobre a evolução do instituto da responsabilidade, deixando evidente que sua marcha está vinculada à evolução do próprio Estado que, passando por regimes totalitaristas e ditatoriais, vem se lapidando no tempo e no espaço.

No segundo capítulo, iniciaremos situando o papel do Estado e o que se espera dele; tais considerações servem para deixar evidente qual é o objetivo para o qual o Estado foi concebido, e qual é, verdadeiramente, seu papel no contexto social. Como ente depositário daquela parcela de liberdade outorgada pelos cidadãos mediante a celebração do "Contrato Social", a existência do Ente Estatal se faz imprescindível para que haja convívio comunitário harmônico e equilibrado, não lhe sendo facultado furtar-se de seu dever de agir, hipótese que se concretiza quando o Estado se ausenta ou se escusa do dever de cumprir seu papel. Restringindo um pouco mais o tema, enfocar-se-á a responsabilidade extracontratual do Estado, excluindo-se, da presente reflexão, a responsabilidade contratual do Estado, e identificando-se os pressupostos para sua caracterização.

No campo da omissão destacar-se-á a posição da doutrina e da jurisprudência, que apesar de atualmente estar em vias de pacificação, já enfrentou grandes períodos de tormenta.

O estudo da responsabilidade do Estado por comportamento omissivo alberga amplo campo de debate jurídico, sobretudo no que diz respeito à aplicação da teoria objetiva, como já dissemos. Primeiramente, é necessário compreender que a omissão estatal decorre de comportamento ilícito, configurado pela inércia, pois só é possível a verificação da omissão quando existir o dever de agir por parte do Estado ou a possibilidade de agir $^{3}$. A dificuldade da teoria diz respeito à possibilidade de agir; tem de haver configuração em conduta que seja exigível e que seja possível.

Aspectos importantes, que não poderíamos deixar de analisar, dizem respeito à reparação e à indenização pelo dano causado, à denunciação da lide, à ação regressiva contra

\footnotetext{
${ }^{3}$ DI PIETRO, Maria Sylvia Zanella. Direito Administrativo. 24. ed. São Paulo: Atlas, 2011. p.655.
} 
o agente causador do dano e, por último, à prescrição, encerrando este capítulo com uma conclusão parcial.

O terceiro capítulo é reservado a um estudo, ainda que conciso, do princípio da prevenção e da precaução como mecanismo de evitar a ocorrência do dano. Conforme já exposto, no mundo em que vivemos, fatos e atos modificam a natureza das coisas e a vida das pessoas, para melhor ou para pior, conforme disposição das normas e regras ou com a infração de tais normas ou regras. Em certa medida, os acontecimentos têm vontade própria, ocorrem independentemente do querer humano e proporcionam grandes ou pequenas mutações nas coisas e nos indivíduos. Nesses casos, via de regra, nenhum indivíduo é responsável pelo evento, nenhuma pessoa natural ou jurídica, ou, ainda, entidade criada pelo homem é chamada a responder pelas mudanças operadas, como lhes tendo dado causa.

No entanto, mesmo no terreno dos fatos, pode incidir a responsabilização, como, por exemplo, na situação em que a previsibilidade humana poderia ter ceifado os efeitos danosos do fato do mundo. Neste caso, excepcionalmente, o indivíduo adere ao fato para efeitos de responsabilidade, porque embora não seja causa direta do fato é causa direta do dano, pois podendo impedi-lo não o fez ${ }^{4}$.

No capítulo quatro analisar-se-á o "Controle” da Administração Pública, como um forte aliado no combate à inércia estatal. O Direito Administrativo coloca à disposição da Sociedade Civil várias formas de controle da atividade administrativa e política (voto), entretanto, a omissão individual em participar do processo político e democrático acarreta a ampliação do arbítrio governamental. Destacar-se-á (1) o Controle interno como aquele exercido pela própria Administração na relação de subordinação hierárquica, sobre seus próprios atos e agentes, ou por sistema de auditoria que acompanha seu exercício; e (2) o Controle externo da Administração Pública que é feito pelo Parlamento, por intermédio do Tribunal de Contas e pelo Judiciário.

Esta dissertação não se prende somente ao raciocínio mecânico e insípido acerca da lei em vigor ou da jurisprudência dominante neste momento, mas foi implementada a tentativa de vasculhar o arcabouço jurídico fundamentador do sistema jurídico brasileiro, propondo nova perspectiva sobre o tema.

As reflexões aqui expostas têm a finalidade, além de analisar a responsabilidade do Estado por omissão, também de reconsiderar as bases do direito administrativo, pois só é concebível um direito que privilegie a visão antropocêntrica, mesmo porque o ser humano é a

\footnotetext{
${ }^{4}$ CRETELLA JR., José. O Estado e a obrigação de indenizar. Rio de Janeiro: Forense, 2002. p. 25.
} 
razão de o Estado existir. O Estado assumiu o importante papel de concretizar os direitos fundamentais e, justamente por isso, tem obrigação de lançar mão de todos os recursos a fim de garantir sua efetivação, por meio de controles e da adoção dos princípios da prevenção e da precaução.

Infelizmente, a ausência de consciência coletiva é uma constante entre nós. A irresponsabilidade dos agentes políticos, principalmente, é tomada como algo inerente à atividade governamental. A satisfação do interesse individual, por meio do sacrifício de direitos alheios, especialmente da coletividade, parece ser algo totalmente indissociável do exercício do Poder, situação com a qual não devemos pactuar jamais.

Em apertada síntese, esta é a sumarização do tema que busca homenagear o estudo sobre a responsabilidade do Estado por omissão, destacando o controle da Administração Pública e a aplicação do princípio da prevenção e da precaução como forma de evitar a ocorrência do dano. 


\section{ASPECTOS GERAIS SOBRE A RESPONSABILIDADE DO ESTADO}

\subsection{DEFINIÇÃO DE RESPONSABILIDADE DO ESTADO}

A Responsabilidade do Estado é um dos temas mais estimulantes na órbita da ciência do Direito, fundamentalmente pelos diversos aspectos de análise que envolve. Dentro dessa esfera temática de tão ampla magnitude, vê-se que alcança não só a responsabilidade da Administração Pública como, também, a do Estado Legislador e a do Estado Juiz. Nesse contexto, a responsabilidade por omissão, objeto específico desta dissertação, desperta grande interesse dos estudiosos pelas incontáveis considerações que admite.

De início, para compreender esse instituto, é preciso empreender a tentativa de esquadrinhar todos os seus aspectos, começando pela etimologia da palavra. $\mathrm{O}$ vocábulo "responsabilidade" deita sua raiz, "spond", no verbo latino respondere, cujo significado é responder ou replicar. Responsável é aquele que formula resposta, a qual é resultante de um estímulo anterior causativo - a pergunta. A pergunta e a resposta são faces opostas do diálogo ${ }^{1}$.

De acordo com José Maria Pinheiro Madeira ${ }^{2}$ :

A noção da palavra responsabilidade pressupõe um limite à ação humana. Não fossem as normas que permeiam a vida em sociedade, os indivíduos agiriam com total arbitrariedade e causariam frequentes danos uns aos outros. Portanto, é a responsabilidade que cria um liame entre as pessoas e um mundo moral, social e juridicamente organizado, pois prevê a obrigação da reparação de eventuais danos causados aos outros.

Do ponto de vista semântico, podemos considerar que responsabilidade ou responsabilização é a contrapartida, a oposição da conta devida por aquele que provocou um dano. A Responsabilidade está presente em vários contextos da atividade humana, é instituto comum tanto no direito público, quanto no direito privado. José Cretella Júnior ${ }^{3}$ ensina que tanto a responsabilidade privada quanto a pública são duas faces que pertencem ao gênero mais amplo - responsabilidade. Entretanto, a teoria da responsabilidade privada foi elaborada

\footnotetext{
${ }^{1}$ CRETELLA JR. José. O Estado e a Obrigação de Indenizar. 2. ed. Rio de Janeiro: Forense, 2002. p. 9.

${ }^{2}$ MADEIRA. José Maria Pinheiro. Administração Pública, TOMO II. 11. ed. Rio de Janeiro: Elsevier, 2010. p. 249.

${ }^{3}$ CRETELLA JR. José. O Estado e a Obrigação de Indenizar. 2.ed. Rio de Janeiro: Forense, 2002. p. 14-22.
} 
pelos romanos há muitos séculos, ao passo que a teoria da responsabilidade pública é construção do direito moderno (Conselho de Estado Francês).

Segundo René Savatier ${ }^{4}$, “La responsabilité civil est l'obligation qui peut incomber à une personne de reparer le dommage causé à autrui par son fait, ou par le fait des personnes ou de chose dépenddant d'elle". 5

O instituto da "Responsabilidade" transcende quase todos os ramos do Direito, adquirindo, em cada um deles, pressupostos e sentidos diversos. A responsabilidade penal distancia-se da responsabilidade patrimonial pela natureza do bem lesionado: enquanto aquela encontra campo de incidência quando a lesão afeta diretamente a ordem social, com significativo grau de lesividade, a outra incide quando há violação de direito subjetivo, absoluto ou relativo ${ }^{6}$.

Segundo Fabiano André de Souza Mendonça ${ }^{7}$ :

Para entender esse processo, é preciso que se atente para os fatores de legitimidade existentes dentro do ordenamento, os quais pautarão o relacionamento deste com a justiça. Por esse caminho, alcança-se o fundamento filosófico da responsabilidade (Responsabilidade do Estado por ato judicial inconstitucional. RT 738/12).

Rui Stoco ${ }^{8}$ considera que é difícil conceituar a ideia de responsabilidade; o conceito de obrigação é o mais próximo de uma definição razoavelmente precisa. Digamos que, para ele, responsável, responsabilidade, assim como todos os vocábulos cognatos, exprimem a ideia de contraprestação ou correspondência. A responsabilidade não é fenômeno exclusivo da vida jurídica, antes vincula todos os domínios da vida social, sendo, portanto, resultado da ação pela qual o homem expressa o seu comportamento, em face desse dever ou obrigação.

\footnotetext{
${ }^{4}$ SAVATIER, René. Traité de la responsabilité civile em droit français. Paris: R. Picho net R. Durand Auzias, 1951, t. 1, apud FERREIRA, Antônio Carlos. Responsabilidade Civil por Atos da Administração Pública. São Paulo: Alfabeto Jurídico, 2002. p. 38.

5 “A responsabilidade civil é a obrigação que pode ser imposta a uma pessoa de reparar um dano causado a outrem por fato seu ou por fato de pessoas ou coisas dele dependentes" (tradução livre).

${ }^{6}$ PONTES DE MIRANDA apud LOBÃO, Marcelo Meireles. Responsabilidade do Estado pela Desconstituição de Contratos Administrativos em Razão de Vícios de Nulidade. São Paulo: Malheiros, 2008. p. 14.

${ }^{7}$ MENDONÇA, Fabiano André de Souza apud STOCO, Rui. Tratado de Responsabilidade Civil. 6. ed. São Paulo: Revista dos Tribunais, 2004. p. 118.

${ }^{8}$ STOCO, Rui. Tratado de Responsabilidade Civil. 6. ed. São Paulo: Revista dos Tribunais, 2004. p. 119.
} 
José Aguiar Dias ${ }^{9}$ ensina que:

Para realizar a finalidade primordial de restituição do prejudicado à situação anterior, desfazendo, quanto possível, os efeitos do dano sofrido, tem-se o direito empenhado extremamente em todos os tempos. A responsabilidade civil é reflexo da própria evolução do direito, é um dos mais acentuados característicos. É preocupação, no direito civil, só comparável à que inspira o instituto da pena, outro sinal distinto do progresso jurídico.

Para Sílvio de Salvo Venosa ${ }^{10}$, "responsabilidade" é termo empregado em qualquer situação na qual determinada pessoa, física ou jurídica, se obriga a arcar com os reflexos de um ato, fato ou negócio danoso. Nesse passo, toda atividade humana, portanto, pode resultar no dever de indenizar. Dessa maneira, o estudo da responsabilidade civil abrange todo o conjunto de princípios e normas que regem a obrigação de indenizar.

De acordo com Caio Mário da Silva Pereira ${ }^{11}$, responsabilidade civil consiste na efetivação da reparabilidade abstrata do dano em relação a um sujeito passivo da relação jurídica que se forma. Reparação e sujeito passivo compõem o binômio da responsabilidade civil.

No que diz respeito à chamada Responsabilidade Civil do Estado, esta pode ser compreendida como a obrigação legal imposta ao Poder Público de reparar danos suportados por terceiros em decorrência da atividade estatal. A violação de um dever jurídico preexistente que faz surgir a obrigação de reconstituir o patrimônio lesionado.

A sujeição das pessoas públicas ou privadas à ordem jurídica é considerada "um dos pilares do moderno Direito Constitucional”, e a lesão aos bens jurídicos de terceiros obriga o autor do dano à reparação ${ }^{12}$.

Celso Antônio Bandeira de Mello ${ }^{13}$ assevera que a responsabilidade do Estado governa-se por princípios próprios, compatíveis com a peculiaridade de sua posição jurídica, e, por isso mesmo, é mais extensa que a responsabilidade que pode calhar às pessoas privadas. As funções estatais rendem ensejo à produção de danos mais intensos que os suscetíveis de

\footnotetext{
${ }^{9}$ DIAS, José Aguiar. Da Responsabilidade Civil. 12. ed. Rio de Janeiro: Lumen Juris, 2011. p. 18.

${ }^{10}$ VENOSA, Sílvio Salvo. Direito Civil-Responsabilidade Civil. vol. 4. 11. ed. São Paulo: Atlas, 2011. p. 1.

${ }^{11}$ PEREIRA, Caio Mário da Silva. Responsabilidade Civil - De acordo com a Constituição de 1988. Rio de Janeiro: Forense, 1996. p. 11.

${ }^{12}$ BÜHRING, Marcia Andrea. Responsabilidade Civil Extracontratual do Estado. São Paulo: Thompson-IOB, 2004. p. 78.

${ }^{13}$ BANDEIRA DE MELLO, Celso Antônio. Curso de Direito Administrativo. 28. ed. São Paulo: Malheiros, 2011. p. 1005.
} 
serem gerados pelos particulares. As condições que podem ocasioná-los também são distintas, uma vez que:

[...] os deveres públicos do Estado o colocam permanentemente na posição de obrigado a prestações multifárias das quais não se pode furtar, pena de ofender o Direito ou omitir-se em sua própria missão, seja porque dispõe do uso normal de força, seja porque seu contato onímodo e constante com os administrados lhe propicia acarretar prejuízos em escala macroscópica, o certo é que a responsabilidade estatal por danos há de possuir fisionomia própria, que reflita a singularidade de sua posição jurídica. Sem isso, o acobertamento dos particulares contra os riscos da ação pública seria irrisório e por inteiro insuficiente para resguardo de seus interesses e bens jurídicos.

A vida em sociedade está regulada por normas que buscam atingir o equilíbrio e a harmonia social, afastando as arbitrariedades que podem ocasionar prejuízos aos indivíduos que integram o grupo. A responsabilização imposta aos causadores de danos estabelece um limite à ação humana.

Diógenes Gasparini ${ }^{14}$ acentua o que ele designa de Responsabilidade Civil do Estado como "a obrigação que lhe atribui de recompor os danos causados a terceiros em razão de comportamento unilateral comissivo ou omissivo, legítimo ou ilegítimo, material ou jurídico, que lhe seja imputável”.

A reparação dos atos danosos praticados por agentes públicos é inerente da lógica do Estado de Direito, o qual submete todos ao império da lei. Nessa esteira de raciocínio, além do princípio da legalidade impõe-se, também, o princípio da igualdade e da justiça.

A doutrina recorre às diferentes terminologias para denominar o tema em questão, alguns utilizam a qualificadora "civil”, remetendo à natureza privada do instituto em oposição à "penal". Outros preferem adotar nomenclaturas como Responsabilidade Patrimonial do Estado ou Responsabilidade Extracontratual do Estado, ou simplesmente Responsabilidade do Estado.

É certo que o regime de responsabilização privado difere do regime público. Também é inquestionável o fato de que "[...] o direito da responsabilidade civil é um direito de reparação de danos. O atributo 'civil' diferencia-se da responsabilidade penal, pois a reparação do dano acarreta consequências jurídicas da punição pelo cometimento de infrações criminais". 15

\footnotetext{
${ }^{14}$ GASPARINI, Diógenes. Direito Administrativo. 17. ed. São Paulo: Saraiva, 2012. p. 1123.

${ }^{15}$ NOHARA, Irene Patrícia. Direito Administrativo. São Paulo: Atlas, 2011, p. 735.
} 
José Cretella Júnior critica a utilização da expressão "Responsabilidade Civil do Estado", pois segundo sua percepção, a pessoa jurídica é insuscetível de outros tipos de responsabilizações ${ }^{16}$. A responsabilidade decorre de ação ou omissão, dolosa ou culposa, cuja consequência seja a produção de um prejuízo. Comungando do mesmo entendimento de Georges Vedel ${ }^{17}$, assevera que a responsabilidade civil, de modo mais apropriado, deveria ser denominada responsabilidade patrimonial, uma vez que envolve, antes de tudo, o dano, o prejuízo, o desfalque, o desequilíbrio e, ainda, a descompensação do patrimônio de alguém.

Alguns doutrinadores entendem que não há como aplicar a responsabilidade penal ao Estado, pois a estrutura do ordenamento jurídico-penal brasileiro e os princípios correspondentes seriam incompatíveis com a aplicação da responsabilidade penal à pessoa jurídica. A responsabilidade pessoal, que se constitui um dos pilares do Direito Penal, mostrar-se-ia incompatível com essa modalidade de responsabilidade; por outro lado, devemos considerar que a pessoa jurídica não pratica fato típico, exatamente por não possuir vontade e culpabilidade.

No Brasil, atualmente, a responsabilidade penal também pode ser aplicada ao Estado, em decorrência de delitos contra a ordem econômica e crime ambiental, previstos respectivamente, no $\S 5^{\circ}$, do artigo 173 , e $\S 3^{\circ}$, do artigo 225 da Constituição Federal vigente, in verbis:

Art. 173

$\S 5^{\circ}$ - A lei, sem prejuízo da responsabilidade individual dos dirigentes da pessoa jurídica, estabelecerá a responsabilidade desta, sujeitando-a às punições compatíveis com sua natureza, nos atos praticados contra a ordem econômica e financeira e contra a economia popular.

Art. 225 -

$\S 3^{\circ}$ - As condutas e atividades consideradas lesivas ao meio ambiente sujeitarão os infratores, pessoas físicas ou jurídicas, a sanções penais e administrativas, independentemente da obrigação de reparar os danos causados.

No que se refere aos crimes ambientais, o referido comando legal estabeleceu que a responsabilidade penal não se dirige exclusivamente às pessoas físicas, mas alcança também as pessoas jurídicas. Nesse diapasão, veio a Lei 9.605, de 12 de fevereiro de 1988, cujos artigos 21, 22 e 23 determinam quais são as penas impostas às pessoas jurídicas, senão vejamos:

\footnotetext{
${ }^{16}$ CRETELLA JR. José. O Estado e a Obrigação de Indenizar. 2. ed. Rio de Janeiro: Forense, 2002. p. 27-41.

${ }^{17}$ VEDEL, Georges. Droit Administratif. 5.ed. Paris: Presses Universitaires de France, 1973. p. 325.
} 
Art. 21. As penas aplicáveis isolada, cumulativa ou alternativamente às pessoas jurídicas, de acordo com o disposto no art. $3^{\circ}$, são:

I - multa;

II - restritivas de direitos;

III - prestação de serviços à comunidade.

Art. 22. As penas restritivas de direitos da pessoa jurídica são:

I - suspensão parcial ou total de atividades;

II - interdição temporária de estabelecimento, obra ou atividade;

III - proibição de contratar com o Poder Público, bem como dele obter subsídios, subvenções ou doações.

Art. 23. A prestação de serviços à comunidade pela pessoa jurídica consistirá em:

I - custeio de programas e de projetos ambientais;

II - execução de obras de recuperação de áreas degradadas;

III - manutenção de espaços públicos;

IV - contribuições a entidades ambientais ou culturais públicas.

Art. 24. A pessoa jurídica constituída ou utilizada, preponderantemente, com o fim de permitir, facilitar ou ocultar a prática de crime definido nesta Lei terá decretada sua liquidação forçada, seu patrimônio será considerado instrumento do crime e como tal perdido em favor do Fundo Penitenciário Nacional.

É inegável que, nos últimos tempos, houve um grande avanço, no que tange à conscientização da relevância da proteção ao meio ambiente. Até a década de 1.970, havia um desinteresse e um vácuo no que diz respeito à questão ambiental, que se explicava pela pouca ocorrência de acidentes ecológicos e, sobretudo, pelo consenso de que o crescimento econômico era incompatível com a harmonia ambiental ${ }^{18}$. Por esta razão, manifestou-se grande preocupação do legislador em punir, inclusive criminalmente, os maiores poluidores, que quase sempre são grandes indústrias.

Com o intuito de tornar mais clara a discussão sobre o cabimento da responsabilidade penal da pessoa jurídica, defendo tal possibilidade, a doutrina vem se debruçando sobre a chamada teoria da responsabilidade penal por ricochete, que determina ser imprescindível para a responsabilização da pessoa jurídica que haja prática do ato unível por uma pessoa física. Assim, primeiramente, uma pessoa física é incriminada e, posteriormente, por reflexo, alcança-se a pessoa jurídica, desde que preenchidos os requisitos legais, como a atuação em nome da pessoa jurídica e em benefício desta.

Os delitos praticados contra o meio ambiente ou ecológicos, os crimes contra a ordem econômica e as relações de consumo apresentam semelhanças e características comuns, visto que repercutem sobre o tema de concurso de agentes, uma vez que são

\footnotetext{
${ }^{18}$ LEMOS, Patrícia Faga Iglecias. Direito Ambiental Responsabilidade Civil e Proteção ao Meio Ambiente. 2. ed. reformulada e atualizada da obra Responsabilidade civil por dano ao meio ambiente. São Paulo: Revista dos Tribunais, 2008. p. 23.
} 
infrações perpetradas contra a coletividade, atentando também contra os interesses difusos, assumindo caráter de pluralidade de ofensas.

José Cretella Júnior ${ }^{19}$ não admite a ideia de imputação da responsabilidade penal ao Estado, bem como às demais pessoas jurídicas ou pessoas morais, conforme se verifica na doutrina francesa, pois para ele essas entidades estão isentas desse tipo de responsabilização. $\mathrm{O}$ argumento que sustenta sua posição é o fato de a pessoa jurídica, metafisicamente, não ter vontade, sendo inimputável.

Entretanto, o conceito de culpabilidade deve ser distinto com relação à pessoa natural e à jurídica, pois no que tange à pessoa jurídica, esta não tem a potencial consciência da ilicitude como elemento, exigível quando se refere à pessoa natural. Não se pode buscar, na pessoa jurídica, o que não se pode ter, que é a consciência da ilicitude, porém se pode encontrar uma conduta e chegar a um juízo de reprovação social e criminal sobre a ação da pessoa jurídica.

Ao lado das responsabilidades penal e patrimonial, também podem ser vislumbradas as responsabilidades administrativa, disciplinar, a política e a político-social, impostas aos agentes públicos ${ }^{20}$. Entretanto, esse tópico será tratado mais detidamente mais adiante, quando cuidaremos da responsabilidade do Agente Público.

Élcio Trujillo juntou-se aos que repudiam a utilização do adjetivo para qualificar a responsabilidade estatal, já que tal qualificadora poderia induzir equivocadamente à ideia de que a relação jurídica em questão seria regida pelo Direito Privado ${ }^{21}$.

Hely Lopes Meirelles ${ }^{22}$ denomina a responsabilização estatal de "Responsabilidade Civil da Administração", justificando que se impõe à Fazenda Pública a obrigação de compor o dano causado a terceiros por agentes públicos, no desempenho de suas atribuições ou a pretexto de exercê-las, sendo distinta da responsabilidade contratual ou legal.

Analisando os controvertidos argumentos elaborados pela doutrina, tanto brasileira quanto estrangeira, todos muito bem fundamentados, a expressão Responsabilidade Extracontratual do Estado é a que nos parece mais adequada na abordagem do referido Instituto. Entretanto haverá passagens no presente trabalho em que se utilizará a expressão

\footnotetext{
${ }^{19}$ CRETELLA JR., José. O Estado e a obrigação de indenizar. Rio de Janeiro: Forense, 2002. p. 36.

${ }^{20}$ ARAUJO, Edmir Netto. Curso de Direito Administrativo. 5. ed. São Paulo: Saraiva, 2010. p. 766.

${ }^{21}$ TRUJILLO, Elcio. Responsabilidade do Estado por atos lícitos. São Paulo: Leaud, 1996. p. 36.

${ }^{22}$ MEIRELLES, Hely Lopes. Direito Administrativo Brasileiro. 37. ed. São Paulo: Malheiros, 2011. p. 1001.
} 
Responsabilidade Civil, apenas com o objetivo de não confundi-la com outro instituto e respeitando o posicionamento do doutrinador que optar pela referida expressão.

\subsubsection{Responsabilidade $\mathrm{x}$ sacrifício de direito}

Um ponto importante que merece ser destacado, no âmbito do estudo da responsabilidade estatal, é a distinção entre a responsabilidade e o sacrifício de direito. Enquanto a responsabilização do Estado se configura no dever de reparar os danos causados em decorrência da atividade estatal, o sacrifício de direito mostra sua face nas situações em que o Estado não tem outra alternativa, senão investir contra direitos de particulares, em benefício do interesse coletivo. Como exemplos ilustrativos, apontamos a desapropriação, a servidão, o tombamento, a requisição e a ocupação temporária.

A doutrina italiana utiliza o vocábulo "indenização" para as hipóteses de sacrifício de direito, reservando o emprego do termo "ressarcimento" para os casos de responsabilidade ${ }^{23}$.

Dessa forma, a responsabilidade pressupõe violação de um direito. Se não há violação de um direito, mas apenas sacrifício de um direito, previsto e autorizado pelo ordenamento jurídico, não se cogitará a responsabilidade do Estado.

Carlos Ari Sundfeld ${ }^{24}$ relata que:

O Estado dispõe, igualmente, de poderes para sacrificar os direitos patrimoniais privados, total ou parcialmente, quando isso se tornar necessário à realização dos interesses públicos e sociais, tal como definidos em lei. Estamos aqui diante de técnica de intervenção muito mais acentuada do que a referente aos condicionamentos administrativos, a justificar a existência, como pressupostos de seu exercício, de limites e procedimentos bastante diferenciados.

Élcio Trujillo ${ }^{25}$ vai mais além, fazendo, ainda, uma distinção entre o condicionamento de direito e sacrifício de direito; de acordo com sua análise, o

\footnotetext{
${ }^{23}$ BANDEIRA DE MELlo, Celso Antônio. Curso de Direito Administrativo. 28. ed. São Paulo: Malheiros, 2011. p. 1.003 .

${ }^{24}$ SUNDFELD, Carlos Ari. Direito Administrativo Ordenador. São Paulo: Malheiros. 1993. p. 86, apud TRUJILLO, Élcio. Responsabilidade do Estado por atos lícitos. São Paulo: Leaud, 1996. p. 96.

${ }^{25}$ TRUJILLO, Elcio. Responsabilidade do Estado por ato Lícito. São Paulo: LED - Editora do Direito, 1996. p. 97.
} 
condicionamento de direito pressupõe um ato correspondente a gravame normal considerado como indispensável e coerente com os níveis de exigência da vida social, ou que não provoca prejuízo, ou se provoca é por breve espaço de tempo ou em extensão reduzida. Por outro lado, o sacrifício de direito se caracterizaria pelo constrangimento extraordinário ou excedente dos padrões de normalidade habitualmente aceitos.

Para Celso Antônio Bandeira de Mello ${ }^{26}$, interesse público não é a soma dos interesses de cada um dos membros da sociedade, mas o conjunto de interesse do corpo social. Isto é, o interesse que habita em cada membro do corpo social enquanto elemento integrante da Nação, e não como partícula destacada do todo unitário. Ele classifica como interesse público aquele resultante do conjunto dos interesses que os indivíduos pessoalmente têm quando considerados em sua qualidade de membros da sociedade pelo simples fato de o serem.

De acordo com Maurício Zockun ${ }^{27}$, quando referimo-nos a sacrifício de direito, o Estado ou quem lhe faça as vezes gozará de prerrogativa jurídica para legitimamente investir contra um direito subjetivo ou um interesse juridicamente tutelado. Nessa hipótese, o dano infligido a direito de terceiro é classificado como lesão jurídica, havendo, assim, um dano lícito. O referido autor equipara sacrifício de direito ao dano lícito indenizável, decorrendo de hipótese tipificadora de sacrifício de direito.

A doutrina aponta as seguintes medidas estatais que fazem nascer o sacrifício de direito: ocupação temporária, requisição, tombamento, servidão administrativa e desapropriação.

O problema da responsabilidade do Estado não se confunde com a obrigação do Poder Público de indenizar os particulares, nos casos em que a ordem jurídica lhe autoriza investir diretamente contra o direito de terceiros, havendo a necessidade de sacrificar certos interesses privados e convertê-los em sua correspondente expressão patrimonial.

Entende-se que se o interesse público não pode ser satisfeito sem o sacrifício de um interesse privado, ambos tutelados pelo ordenamento jurídico, a solução reside no dever de indenizar aquele cujo direito foi sacrificado. Para tanto, não há que se falar em responsabilidade, propriamente dita, na hipótese em que o Estado debilita, enfraquece, sacrifica o direito de outrem, ao exercitar um poder que a ordem jurídica lhe confere.

\footnotetext{
${ }^{26}$ BANDEIRA DE MELlo, Celso Antônio. Curso de Direito Administrativo. 28. ed. São Paulo: Malheiros, 2011. p.61.

${ }^{27}$ ZOCKUN, Maurício. Responsabilidade Patrimonial do Estado. São Paulo: Malheiros, 2010. p.83.
} 
A afirmação de que sacrifício de direito não se confunde com responsabilidade do Estado não impede a aceitação da responsabilidade do Estado por atos lícitos, pois sacrifício de direito consiste na previsão legislativa de um poder em prol do Estado, cujo conteúdo reside especificamente em aniquilar um direito alheio, que se converterá em correlativa expressão patrimonial, enquanto que a responsabilidade do Estado por atos lícitos será cabível nas hipóteses em que o poder deferido ao Estado legitimamente exercido acarreta, indiretamente, como simples consequência, não como sua finalidade própria, a lesão a um direito alheio ${ }^{28}$.

\subsection{TEORIAS SOBRE A RESPONSABILIDADE DO ESTADO}

A dinâmica social é um fenômeno que, ao longo do tempo, impõe inúmeras transformações aos diversos institutos jurídicos a fim de acomodá-los às necessidades do povo, e com relação à responsabilidade estatal não foi diferente.

A irreversível marcha do tempo fez com que o Estado mudasse suas feições de acordo com as ideologias predominantes; como reação a essas mudanças, ele (Estado) foi se remodelando. Diante de tal realidade, tornou-se imprescindível a elaboração de teorias que melhor se adaptassem àquela realidade correspondente. A análise da evolução das teorias é importante para que se possa compreender como esse processo se desenrolou. $\mathrm{O}$ desenvolvimento das teorias acerca da responsabilização do Estado pode ser posicionado em três sistemas principais: (a) Teoria da Irresponsabilidade ou regaliana; (b) Teoria Civilista ou mista; e (c) Teorias publicísticas ${ }^{29}$.

Maria Sylvia Zanella Di Pietro ${ }^{30}$ adverte que:

Antes de analisar cada uma das teorias, cabe assinalar que existe muita divergência de terminologia entre os autores, o que torna difícil a colocação da matéria; o que alguns chamam de culpa civil outros chamam de culpa administrativa; alguns consideram como hipóteses diversas a culpa

\footnotetext{
${ }^{28}$ Celso Antônio Bandeira de Mello esclarece, ainda, que há casos em que o Estado é autorizado pelo Direito à prática de certos atos que não têm por conteúdo próprio sacrificar direito de outrem, entretanto, o exercício destes atos pode vir a atingir direitos alheios, violando-os, como simples resultado ou sequela de uma ação legítima.

${ }^{29}$ ARAUJO, Edmir Netto de. Curso de Direito Administrativo. 5. ed. São Paulo: Saraiva, 2010. p. 771.

${ }^{30}$ DI PIETRO, Maria Sylvia Zanella. Direito Administrativo. 24. ed. São Paulo: Atlas, 2011. p. 643.
} 
administrativa e o acidente administrativo; alguns subdividem a teoria do risco em duas modalidades, risco integral e risco administrativo.

\subsubsection{Teoria Regalista - o Estado irresponsável}

A tese do Estado Irresponsável repousa na concepção dos governos absolutistas ou despóticos; naquele tempo acreditava-se que o rei era um representante de Deus na Terra, e por isso era considerado como a encarnação ou personificação do Estado, e seu poder encarado como irrestrito.

Essa teoria estava respaldada na crença de que o Rei não se sujeitava à lei e seus atos não eram submetidos aos Tribunais. Tal concepção se traduzia nos brocardos: "The king can do no wrong” (o Rei não erra), "Le roi ne peut mal faire” (o Rei não pode fazer mal), ou ainda, "quod principi placuit Haber legis vigorem" (aquilo que agrada o príncipe tem força de lei). O Estado não podia, portanto, ser responsabilizado, já que o Rei jamais causava danos, pois ele era tão superior que não cometia erros, dessa forma estava desvinculado do ato danoso causado pelo agente ${ }^{31}$.

Irene Patrícia Nohara aponta que "trata-se de período denominado de Estado de Polícia (do alemão, Polizeistaat), que se desenvolveu tipicamente na Prússia, no momento em que Frederico II - o Grande adotou o chamado despotismo esclarecido". 32

Um dos mais importantes defensores do absolutismo, o teólogo francês Jacques Benigne Bossuet ${ }^{33}$, em 1.708, em sua obra denominada Politique tirée des propres paroles de l'Ecriture sainte, elaborou a doutrina do direito divino, segundo a qual qualquer governo formado legalmente é a mais pura expressão da vontade de Deus, sendo assim tido como sagrado. Qualquer oposição a esse governo seria, desse modo, considerada como criminosa. Bossuet era tão apaixonado pela doutrina absolutista que chegou a questionar a autoridade do próprio Papa em oposição aos poderes dos Reis.

A teoria da Irresponsabilidade estatal há tempos foi abandonada pelos Estados modernos, as únicas civilizações que resistiam eram a Inglaterra e os Estados Unidos, todavia

\footnotetext{
${ }^{31}$ ARAUJO, Edmir Netto de. Curso de Direito Administrativo. 5. ed. São Paulo: 2010. p. 771.

${ }^{32}$ NOHARA, Irene Patrícia Direito Administrativo. São Paulo: Atlas, 2011. p. 742.

${ }^{33}$ BOSSUET. Jacques Bénigne. Politique tirée des propres paroles de l'Ecriture-Sainte. Paris: Chez Pierre Cot, 1709.
} 
abandonaram-na, respectivamente por força do "Crown Proceeding Act" (1.947), e do "Federal Tort Claims Act" (1.946).

\subsubsection{Teorias Civilistas}

Lentamente, a teoria da irresponsabilidade foi sendo desprezada, pois as bases estruturais do Estado de Direito começavam a despontar e o exercício do poder passava, pouco a pouco, a ser pautado pelo princípio da legalidade, segundo o qual se impunha a aplicação do conteúdo da lei não apenas ao cidadão comum ou súditos, mas também a todos os governantes.

As teorias civilistas (mistas ou intermediárias) buscavam vincular a responsabilidade do Estado por atos de seus representantes com a natureza desses atos, e tinham como fundamento os princípios civilistas aplicados aos particulares, que se escoravam na ideia de culpa.

\subsubsection{Teoria dos atos de impérios e de gestão}

A implementação da teoria civilista ocorreu primeiramente com a divisão das atividades estatais em atos de império e atos de gestão. Atos de império (jus imperii) eram aqueles praticados sob a égide das prerrogativas inerentes ao Estado em relação aos particulares, e a prática de tais atos não implicaria em responsabilização. Por outro giro, os atos de gestão (jus gestionis) eram aqueles desempenhados pelos representantes do Estado na administração de seus bens e serviços em pé de igualdade com os particulares; nesse caso vislumbrava-se a responsabilização.

No decorrer do século XIX, essa concepção foi sendo lentamente ultrapassada, devido à dificuldade de se distinguir a natureza dos atos, e também pela injustiça que se consumava por não haver a reparação de danos provocados pelo Estado no manejo abusivo de suas prerrogativas de poder público ${ }^{34}$. Com a teoria civilista da culpa continuando a ser

\footnotetext{
${ }^{34}$ NOHARA, Irene Patricia. Direito Administrativo. São Paulo: Atlas, 2011. p. 744.
} 
utilizada, o Estado passou a igualar-se ao empregador ou patrão que detinha a responsabilidade objetiva pelos atos de seus empregados e prepostos.

\subsubsection{Teoria da culpa civil ou da responsabilidade subjetiva}

Importante destacar que a teoria da culpa civil serviu como base inspiradora do artigo 15, do Código Civil Brasileiro de 1.916, consagrando no ordenamento jurídico pátrio a responsabilidade subjetiva. Tal modalidade se consubstancia na obrigação de indenizar alguém com base na comprovação de culpa, baseada na concepção privada (civil).

Note-se que o sistema de responsabilização subjetiva do Código Civil de 1.916, conservado pelo Novo Código de 2.002, exigia a comprovação de culpa para viabilizar a pretensão de ressarcimento de danos, mostrando-se absolutamente injusto e inadequado, especialmente para os menos favorecidos. Pela aplicação da responsabilidade subjetiva, as pessoas com capacidade econômica reduzida se viam diante da dificuldade probatória, elemento fundamental para alcançar a indenização.

\subsubsection{Teorias Publicísticas}

Outro marco evolutivo importante da responsabilidade estatal foi fixado com o advento das teorias publicísticas que trouxeram, nas palavras de José Maria Pinheiro Madeira $^{35}$, a despersonalização da culpa, transformada pelo anonimato do agente.

\subsubsection{Teoria da culpa administrativa, culpa anônima ou culpa do serviço}

Por essa teoria, a ideia de culpa foi transferida do agente para a atuação administrativa, ou seja, a vítima estava desobrigada de provar a culpa do agente, bastando

\footnotetext{
${ }^{35}$ MADEIRA, José Maria Pinheiro. Administração Pública. TOMO II. 11. ed. Rio de Janeiro: Elsevier, 2010. p. 256.
} 
apenas comprovar o mau funcionamento do serviço público, daí a designação de culpa publicística, ou ainda culpa do serviço, que mais tarde desmembrou-se em três versões: o mau funcionamento, o não funcionamento ou a demora do serviço ${ }^{36}$.

\subsubsection{Teoria da responsabilidade objetiva ou teoria do risco}

Interessante notar que a maior divergência entre a doutrina não é recepcionar a teoria objetiva como fundamento da responsabilização do Estado e baseada no risco, nesse aspecto já houve pacificação. O ponto nevrálgico da questão é determinar qual modalidade de risco deve ser acatada: a do risco integral ou a do risco administrativo. Para alguns, a teoria adotada é a do risco administrativo; para outros, é a teoria do risco integral. Há, ainda, aqueles que sustentam que, na verdade, não existe diferença entre as teorias, tratando-se, apenas, de uma questão semântica.

Maria Sylvia Zanella Di Pietro ${ }^{37}$ encontra-se entre aqueles que consideram a distinção entre risco administrativo e risco integral como meramente terminológica, para quem "Todos parecem concordar em que se trata de responsabilidade objetiva, que implica averiguar se o dano teve como causa o funcionamento de um serviço público, sem interessar se foi regular ou não [...]”, cabendo a alegação de circunstâncias que excluem ou atenuam a responsabilidade do Estado.

A fase atual de evolução da Responsabilidade do Estado encontra-se calcada na teoria objetiva fundamentada no risco, ou seja, independentemente de qualquer falha ou falta, culpa do serviço público ou ainda, culpa anônima. A atividade administrativa é baseada nos princípios de equidade e igualdade de ônus e encargos sociais, sendo exercida em prol da coletividade, uma vez que traz benefícios para todos; é, pois, justo que todos suportem o ônus. Nessa hipótese, responde o Estado porque causou dano ao seu administrado, apenas e tão somente porque há nexo de causalidade entre a atividade administrativa e o dano suportado pelo particular.

\footnotetext{
${ }^{36}$ MADEIRA, José Maria Pinheiro. Administração Pública. TOMO II. 11. ed. Rio de Janeiro: Elsevier, 2010. p. 257.

${ }^{37}$ DI PIETRO, Maria Sylvia Zanella. Direito Administrativo. 24. ed. São Paulo: Atlas, 2011. p. 647.
} 
Hely Lopes Meirelles ${ }^{38}$ admite a divisão da teoria do risco em duas modalidades: a do risco administrativo, que admite as causas excludentes (culpa da vítima, culpa de terceiros e força maior) e do risco integral (não admite as excludentes). Entretanto assevera que a teoria do risco integral é modalidade extremada da doutrina do risco administrativo, abandonada, na prática, por conduzir ao abuso e à iniquidade social. Para ele, o risco integral jamais foi acolhido entre nós, embora juristas da alta envergadura como Mário Masagão e Octávio de Barros sustentem sua admissibilidade no texto constitucional.

Yussef Said Cahali ${ }^{39}$, criticando a distinção feita por Hely Lopes Meirelles, afirma que esta se revela "artificiosa e carente de fundamentação científica", já que, essencialmente, Meirelles identifica na regra constitucional uma simples presunção de culpa, passível de ser elidida por contraprova apresentada pela Administração Pública. Acrescenta Cahali que a distinção entre risco administrativo e risco integral feita por Hely Lopes leva em consideração, apenas, as consequências de cada modalidade: o risco administrativo admite a contraprova de excludente de responsabilidade: “[...] efeito que se pretende seria inadmissível se qualificado como risco integral, sem que nada seja enunciado quanto à base ou natureza da distinção".

Encerra o seu entendimento asseverando que :

Desenganadamente, a responsabilidade objetiva da regra constitucional concordes todos, doutrina e jurisprudência, em considerá-la como tal - se basta com a verificação do nexo de causalidade entre o procedimento comissivo ou omissivo da Administração Pública e o evento danoso verificado como consequência; o ato do próprio ofendido ou de terceiro, o caso fortuito ou de força maior, arguidos como causa do evento danoso, impediriam a configuração do nexo de causalidade (assim, então, rompido), elidindo daí, eventual pretensão indenizatória.

De acordo com Sérgio Cavalieri Filho ${ }^{40}$, a teoria do risco, adaptada para a atividade pública, serviu como fundamento para a responsabilidade objetiva do Estado, resultando, daí, a teoria do risco administrativo. Para esta, a Administração Pública, em decorrência de suas atividades normais ou anormais, acaba por gerar risco de dano à comunidade. Já que as atividades são exercidas em favor de todos, não parece razoável que apenas alguns arcassem com os ônus por elas gerados, motivo pelo qual deve o Estado, como

\footnotetext{
${ }^{38}$ MEIRELLES, Hely Lopes. Direito Administrativo Brasileiro. 37. ed. São Paulo: Malheiros, 2011. p. 700.

${ }^{39}$ CAHALI, Yussef Said. Responsabilidade Civil do Estado. 3. ed. São Paulo: Revista dos Tribunais, 2007. p. 40.

${ }^{40}$ CAVAlIERI FILHO, Sérgio. Programa de Responsabilidade Civil. 9. ed. revista e ampliada. São Paulo: Atlas, 2010. p. 242-243.
} 
representante do todo, suportar os ônus, independentemente de culpa de seus agentes. Trata-se de "[...] forma democrática de repartir os ônus e encargos sociais por todos aqueles que são beneficiados pela atividade da Administração Pública".

Nessa esteira de raciocínio, Cavalieri Filho ${ }^{41}$ segue, argumentando que essa teoria não se confunde com a teoria do risco integral, a qual se mostra como "modalidade extremada da doutrina do risco para justificar o dever de indenizar mesmo nos casos de culpa exclusiva da vítima, fato de terceiro, caso fortuito ou de força maior". Ao contrário dessa teoria, a teoria do risco administrativo, embora dispense a vítima da prova da culpa, permite ao Estado afastar a sua responsabilidade nos casos de exclusão do nexo causal.

Apesar das divergências, a teoria do risco administrativo vem sendo largamente adotada pela doutrina, tendo em vista que se mostra a mais adequada para a compreensão da responsabilidade do Estado. Entretanto, no ordenamento jurídico brasileiro, a Administração Pública pode ser excepcionalmente responsabilizada na forma de risco integral apenas quando praticar dano ambiental, consoante dispõe o artigo 14 da lei $6.938 / 81$ e o $\operatorname{artigo~} 225, \S 3^{\circ}$ da Constituição Federal, ou dano nuclear, nos termos do artigo 21, XXIII, alinea $d$ da Carta Política.

No Estado de Direito, a norma jurídica protege tanto os interesses individuais como os coletivos, dando amparo a quem sofre danos ou prejuízos sem distinção de qualquer natureza. Nos dias atuais, sabe-se que o Estado se submete ao ordenamento jurídico imposto a todos os membros da sociedade pelo regime democrático, cujo ideário de justiça social configura-se como a base, tendo a legalidade e a igualdade como princípios primordiais.

A Constituição Federal vigente esculpiu, no artigo $37, \S 6^{\circ}$, a responsabilização das pessoas jurídicas de direito público e das de direito privado prestadoras de serviço público pelos danos causados a terceiros causados por seus prepostos, adotando a denominada teoria objetiva, na modalidade de risco administrativo, nos seguintes termos:

\footnotetext{
Art. $37-[\ldots . .$. $\S 6^{\circ}$. As pessoas jurídicas de direito público e as de direito privado prestadoras de serviços públicos responderão pelos danos que seus agentes, nessa qualidade, causarem a terceiros, assegurado o direito de regresso contra o responsável nos casos de dolo e culpa.
}

O artigo 43 do Novo Código Civil Brasileiro, contido na Lei 10.406 de 10 de janeiro de 2.002, replicando o artigo 15 do Código Civil de 1.916, omitiu a expressão

\footnotetext{
${ }^{41}$ CAVAlIERI FILHO, Sérgio. Programa de Responsabilidade Civil. 9. ed. revista e ampliada. São Paulo: Atlas, 2010. p. 244.
} 
"pessoas jurídicas de direito privado prestadoras de serviço público", imprimindo a seguinte redação:

Art. 43. As pessoas jurídicas de direito público interno são civilmente responsáveis por atos dos seus agentes que nessa qualidade causem danos a terceiros, ressalvado direito regressivo contra os causadores do dano, se houver, por parte destes, culpa ou dolo.

Alexandre de Moraes ${ }^{42}$, abraçando a teoria objetiva, assinala que a Constituição Federal determina que as pessoas jurídicas de direito público e as de direito privado prestadoras de serviços públicos responderão pelos danos que seus agentes, nessa qualidade, causarem a terceiros, assegurado o direito de regresso contra o responsável nos casos de dolo ou culpa. Contudo, considera que o princípio da responsabilidade objetiva não se reveste de caráter absoluto, eis que admite o abrandamento e, até mesmo, a exclusão da própria responsabilidade civil do Estado, nas hipóteses excepcionais configuradoras de situações liberatórias - como no caso fortuito e força maior - ou evidenciadoras de ocorrência de culpa atribuível à própria vítima (RDA 137/233 - RTJ 55/50) ${ }^{43}$.

A Responsabilidade do Estado é objetiva, ou seja, independe de culpa, na medida em que este responde pelos atos ou omissões praticados por seus agentes, ou por fatos de coisas sob sua guarda, seu serviço ou vigilância.

É o entendimento esposado por Edmir Netto de Araújo ${ }^{44}$, nos seguintes termos:

[...] o Estado responde pelos danos causados ao particular por seu agente, por ação ou omissão, ou mesmo que não se identifique o causador, mas seja o dano referível ao Estado pelo serviço público ou por coisa à sua guarda, porque a situação jurídica daí decorrente é, repetimos, imputada ao Estado.

A Constituição Federal vigente positivou a hipótese de responsabilização das pessoas jurídicas de direito privado prestadoras de serviços públicos, até então objeto de construção jurisprudencial, já que a legislação ordinária pertinente não o fez a essas entidades (art. 15, do Código Civil de 1.916, replicado pelo art. 43 da Lei 10.406/2002- Código Civil atual).

\footnotetext{
${ }^{42}$ MORAES, Alexandre. Direito Constitucional. 27. ed. São Paulo: Atlas, 2011. p. 389.

${ }^{43}$ STF - $1^{\text {a }}$ t. - Rextr. no 109.615-2/RJ, Rel. Min. Celso de Mello, Diário da Justiça, Seção I, 2 ago. 1996, p. 25.785. No mesmo sentido: Informativo STF - Brasília, 15 a 19 abr. 1996 - no 27, RE 140.270-MG, Rel. Min. Marco Aurélio, 15-4-96. Apud MORAES, Alexandre. Direito Constitucional. 27. ed. São Paulo: Atlas, 2011. p. 389.

${ }^{44}$ ARAUJO. Edmir Netto de. Curso de Direito Administrativo. 5. ed. São Paulo: Saraiva, 2010. p. 769.
} 
A norma constitucional é inequívoca quanto à responsabilização objetiva das pessoas jurídicas de direito público e privado prestadoras de serviços públicos, submetendo ao regime de responsabilização os entes da Administração Direta (União, Estados, Distrito Federal e Municípios), autarquias e fundações públicas, fundação governamental de natureza privada que preste serviço público.

As empresas públicas e sociedades de economia mista, como entes privados, apenas respondem objetivamente, nos termos do artigo $37, \S 6^{\circ}$, da $\mathrm{CF} / 88$, nas hipóteses em que forem prestadoras de serviços públicos; quando desenvolvem atividades econômicas em sentido estrito, submetem-se à responsabilização subjetiva, própria do Direito Civil ${ }^{45}$.

Em conformidade com o artigo 175 da Constituição vigente, as concessionárias e permissionárias de serviços públicos, assim como os tabelionatos e cartórios de notas e registros, desempenhando funções públicas delegadas pelo Estado, também estão sujeitas ao regime imposto pelo artigo em comento, já que agem em nome do Estado, na satisfação do interesse público, interesse este que se concretiza pela prestação de serviços à coletividade.

Nesse aspecto, a obra de Hely Lopes Meirelles sofreu reformulação, nos seguintes termos: ${ }^{46}$

[...] Em edições anteriores, influenciados pela letra da norma constitucional, entendemos excluídas da aplicação desse princípio as pessoas físicas e as pessoas jurídicas que exerçam funções públicas delegadas, sob a forma de empresas estatais ou de empresas concessionárias ou permissionárias de serviços públicos. Todavia, evoluímos no sentido de que também estas respondem objetivamente pelos danos que seus empregados, nessa qualidade, causarem a terceiros, pois, como dissemos precedentemente (cap. VI, item 1.2), não é justo e jurídico que a só transferência da execução de uma obra ou de um serviço originalmente público a particular descaracterize sua intrínseca natureza estatal e libere o executor privado das responsabilidades que teria o Poder Público se o executasse diretamente, criando maiores ônus de prova ao lesado.

Quanto à responsabilização dos tabeliães e notários, existe divergência na doutrina quanto ao regime de responsabilização aplicável, apesar de a corrente majoritária voltar-se para a responsabilidade objetiva, uma vez que não se deve esquecer que eles são considerados agentes públicos, nos exatos termos do art. $37, \S 6^{\circ}, \mathrm{CF} / 88$, além do mais, consideremos, ainda, o disposto na Lei 8.935/94, artigo 22, in verbis:

\footnotetext{
${ }^{45}$ NOHARA. Irene Patrícia. Direito Administrativo. São Paulo: Atlas, 2011. p. 756.

${ }^{46}$ MEIRELLES, Hely Lopes. Direito Administrativo Brasileiro. 37. ed. São Paulo: Malheiros, 2011. p. 703.
} 
Art. 22. Os notários e oficiais de registro responderão pelos danos que eles e seus prepostos causem a terceiros, na prática de atos próprios da serventia, assegurado, aos primeiros, direito de regresso no caso de dolo ou culpa dos prepostos.

Há outra corrente, menos expressiva, que escorada no artigo 38, da Lei 9.492/97, considera a responsabilidade dos tabeliães e notários subjetiva, nos seguintes termos:

Art. 38. Os Tabeliães de Protesto de Títulos são civilmente responsáveis por todos os prejuízos que causarem, por culpa ou dolo, pessoalmente, pelos substitutos que designarem ou Escreventes que autorizarem, assegurado o direito de regresso.

O Supremo Tribunal Federal, em mais de uma oportunidade, decidiu que a responsabilidade por atos de tabeliães e notários deve ser suportada pelo Estado, portanto, de natureza objetiva, pois os cargos são criados por lei, providos mediante concurso, e os atos de seus agentes, sujeitos à fiscalização estatal, são dotados de fé pública, prerrogativa inerente à ideia de poder delegado pelo Estado ${ }^{47}$.

No que diz respeito às atividades ligadas ao Terceiro Setor, acompanhamos os passos de Maria Sylvia Zanella Di Pietro ${ }^{48}$ e Irene Patrícia Nohara ${ }^{49}$, e entendemos que a regra da responsabilidade objetiva, esculpida no artigo $37, \S 6^{\circ}$, deve ser aplicada também para a referida categoria, pois não houve restrição por parte do legislador, e uma vez que desempenham atividades consubstanciadas em serviços públicos, não havendo na lei distinção com relação à natureza jurídica da pessoa jurídica privada prestadora de serviços públicos, no tocante à percepção ou isenção de lucros, impõe-se a responsabilidade objetiva.

José dos Santos Carvalho Filho ${ }^{50}$, por sua vez, adota posição diversa, pois para ele enquanto os serviços autônomos SESI, SENAC, SENAI, SESC estão sujeitos à responsabilidade objetiva atribuída ao Estado, as organizações sociais e as organizações da sociedade civil de interesse público que se vinculam ao Estado, respectivamente, por contrato de gestão ou termo de parceria, estariam sujeitas ao regime do Código Civil, qual seja da responsabilidade subjetiva, pois ele considera excessivo o ônus de prestarem atividades de caráter eminentemente social, desinteressadamente, sem fins lucrativos e, por conta da

\footnotetext{
${ }^{47}$ NOHARA. Irene Patrícia. Direito Administrativo. São Paulo: Atlas, 2011. p. 756.

${ }^{48}$ DI PIETRO, Maria Sylvia Zanella. Direito Administrativo. 24. ed. São Paulo: Atlas, 2011. p. 650.

${ }^{49}$ NOHARA. Irene Patrícia. Op. cit. p. 757.

${ }^{50}$ CARVALHO FILHO, José dos Santos. Manual de Direito Administrativo. São Paulo: Atlas, 2012. p. 551
} 
parceria com o Poder Público, ainda arcarem com o encargo da responsabilização objetiva imposta ao Estado.

Com a reforma na estrutura do Estado, este deixou de executar, por meio de seu próprio aparato, numerosas atividades econômicas e sociais, e passou a fomentar a prestação de atividades de interesse social por entidades privadas. Assim, tornou-se necessária a atuação da sociedade civil organizada, a qual passou a colaborar para o implemento dos objetivos estatais.

A partir dessa visão, o contexto atual demonstra que as entidades privadas, filantrópicas e sem fins lucrativos também desenvolvem serviços de interesse público, e tais atividades são realizadas em nome do Estado. Portanto as entidades sem fins lucrativos, que desenvolvem atividades em substituição ao Poder Estatal, são instrumentos indispensáveis que garantem a realização dos objetivos do Estado Democrático fundado pela Constituição Federal de 1988, razão pela qual justifica-se a responsabilização solidária do Estado pelos danos que eventualmente vierem a causar, evidentemente, observando-se sempre a presença de nexo de causalidade entre o serviço público e o dano suportado pela vítima.

Dentro desse parâmetro, o qual permite concluir que as Entidades privadas exercem atividades exclusivamente estatais, ao garantir em nome do Estado a consecução de serviços públicos, e pela disposição em realizar atividades inerentes ao Estado, o Poder Constituinte criou o benefício da imunidade tributária, como forma aliviar do particular o encargo de fazer as vezes do Poder Público.

Sem a pretensão de aprofundar a questão tributária, e apenas a título de ilustração, destacamos que, na Carta Magna, a educação, a saúde e a assistência social são direitos e garantias de todos, outorgando tais direitos sociais à exploração econômica pela iniciativa privada. As imunidades tributárias surgem como incentivo a que entidades privadas atuem em áreas nas quais o Estado deveria atuar.

Nesse sentido, temos que a imunidade tributária dessas Entidades configura instituto jurídico imprescindível para sua existência e desenvolvimento, pois visa a incentivar as atividades públicas e a fomentar a saúde e a assistência social, pois o contrário inviabilizaria o exercício de tais funções.

Com relação ao posicionamento da jurisprudência, o Supremo Tribunal Federal, em relação à responsabilidade do Poder Público, assegura que:

A teoria do risco administrativo, consagrada em sucessivos documentos constitucionais brasileiros desde a Carta Política de 1946, confere fundamento doutrinário à responsabilidade civil objetiva do Poder Público 
pelos danos a que os agentes públicos houverem dado causa, por ação ou por omissão. Essa concepção teórica, que informa o princípio constitucional da responsabilidade civil objetiva do Poder Público, faz emergir, da mera ocorrência de ato lesivo causado à vítima pelo Estado, o dever de indenizá-la pelo dano pessoal e/ou patrimonial sofrido, independentemente de caracterização de culpa dos agentes estatais ou de demonstração de falta do serviço público. Os elementos que compõem a estrutura e delineiam o perfil da responsabilidade civil objetiva do Poder Público compreendem (a) a alteridade do dano, (b) a causalidade material entre o eventus damni e o comportamento positivo (ação) ou negativo (omissão) do agente público, (c) a oficialidade da atividade causal e lesiva, imputável a agente do Poder Público que tenha, nessa condição funcional, incidido em conduta comissiva ou omissiva, independentemente da licitude, ou não, do comportamento funcional (RTJ 140/636) e (d) a ausência de causa excludente da responsabilidade estatal (RTJ 55/503 - RTJ 71/99 - RTJ 91/377 - RTJ 99/1155 - RTJ 131/417). ${ }^{51}$

Como se observa, o STF, avaliando o conteúdo da Carta Magna relativa ao referido tema, já pacificou o entendimento no sentido de que a teoria objetiva na modalidade de risco administrativo é a que deve ser aplicada à responsabilidade do Estado, pelos danos que seus agentes causarem a terceiros por ação ou omissão, ou por danos oriundos do exercício da atividade estatal.

Assim, para finalizar o raciocínio, a responsabilidade civil das pessoas jurídicas de direito público e das pessoas jurídicas de direito privado prestadoras de serviço público baseia-se na teoria objetiva, na modalidade de risco administrativo. Essa responsabilidade objetiva exige a ocorrência dos seguintes requisitos: ocorrência do dano; ação ou omissão administrativa e ausência de causa excludente da responsabilidade estatal ${ }^{52}$.

\subsection{ASPECTOS HISTÓRICOS}

A história do direito nos demonstra que ele não surgiu aleatoriamente, pelo contrário, sempre esteve condicionado à realidade que se altera conforme a Sociedade vai se modificando, segundo sua marcha no tempo e no espaço.

A análise dos aspectos históricos é fundamental na medida em que descortina todos os acontecimentos, trazendo a lume o encadeamento dos fatos. Não por outro motivo se

\footnotetext{
${ }^{51}$ MORAES, Alexandre. Direito Constitucional. 27. ed. São Paulo: Atlas, 2011. p. 389.

${ }^{52}$ Sobre as características da Teoria Geral da Responsabilidade Civil, aplicáveis ao campo administrativo, conferir: SAMPAIO, Rogério Morrone de Castro. Direito civil: responsabilidade civil. São Paulo: Atlas, 2000.
} 
torna imprescindível trazer à tona tais aspectos, pois assim pode-se compreender a teia sobre a qual o tema se assenta, visualizando-se a linha do tempo até os dias atuais.

A responsabilidade extracontratual se baseia, de acordo com a teoria clássica, em três elementos essenciais: o dano, a culpa do ofensor e a relação de causalidade entre o fato culposo e o dano.

Nos primórdios da humanidade não se cogitava do fator culpa, o dano provocava a reação imediata, instintiva e brutal do ofendido. Não havia regras nem limitações. Não imperava, ainda, o direito. Dominava a vingança privada, forma primitiva, selvagem, talvez, mas humana, da reação espontânea e natural contra o mal sofrido; solução comum a todos os povos nas suas origens, para a reparação do mal pelo mal ${ }^{53}$.

Se a reação não pudesse acontecer desde logo, sobrevinha a vindita meditada, posteriormente regulamentada e que resultou na Lei de Talião - olho por olho, dente por dente - os danos e prejuízos eram compensados por meio de atos violentos. Diante da necessidade de se evitar a instabilidade social e resguardar a segurança de todos os indivíduos, o Estado assume o encargo pela administração da justiça, não mais permitindo o exercício da justiça privada ${ }^{54}$

Com a evolução das sociedades, quando, então, passou a existir uma autoridade soberana, sobreveio a proibição de a vítima fazer justiça pelas próprias mãos. Daí, a composição econômica tornou-se obrigatória e tarifada. $\mathrm{O}$ ofensor ficava obrigado a pagar um tanto por membro roto, por morte de homem livre ou de um escravo, surgindo, em consequência, as mais esdrúxulas tarifações. É a época do Código de Ur-Nammu, do Código de Manu (século XIII a.C.) e da Lei das XII Tábuas ${ }^{55}$.

A distinção entre "pena" e "reparação", começou a mostrar seus contornos com os romanos, a partir da definição de delitos públicos (ofensas graves que perturbavam a ordem pública) e delitos privados. Nos delitos públicos, a pena pecuniária imposta ao ofensor era recolhida aos cofres públicos, enquanto que, nos delitos privados, a pena em dinheiro era endereçada à vítima. O Estado assumiu, assim, ele só, a função de punir ${ }^{56}$.

\footnotetext{
${ }^{53}$ LIMA, Alvino. Da culpa ao risco. São Paulo: Revista dos Tribunais, 1938. p. 10 apud GONÇALVES, Carlos Roberto. Responsabilidade Civil. 13. ed. São Paulo: Saraiva. 2011. p.36.

${ }^{54}$ GIORDANI, José Acir Lessa. A Responsabilidade Civil Objetiva Genérica no Código Civil de 2002. 2. ed. Rio de Janeiro: Lumen Juris, 2007. p. 5.

${ }^{55}$ GONÇALVES, Carlos Roberto. Responsabilidade Civil. 13. ed. São Paulo: Saraiva. 2011. p.37.

${ }^{56}$ Idem, Ibidem. p.37.
} 
De acordo com Caio Mário da Silva Pereira ${ }^{57}$, o Direito Romano não alcançou a construção de uma teoria de responsabilidade civil, como, também, nunca se concentrou na elaboração teórica de nenhum instituto. Todas as referências relativas a esse tema foram construídas com o desenvolvimento dos casos concretos, das decisões dos magistrados e dos pretores, respostas dos jurisconsultos, constituições imperiais, das quais os estudiosos do Direito Romano foram se apropriando, extraindo-lhes os princípios e, desta forma, sistematizando os conceitos.

O advento da Lex Aquilia, por volta do século III a.C., significou um grande avanço em matéria de responsabilização por danos causados, uma vez que instituiu a figura do damnum injuria datum, que consistia em um delito pelo qual alguém causava dano à coisa alheia (sobre referido tema, este será analisado mais detidamente no capítulo seguinte, que tratará da Responsabilidade Extracontratual ou Aquiliana do Estado).

O Código Civil Francês de 1.804, também conhecido como Código de Napoleão, instituiu, em seu artigo 1.382, a responsabilidade subjetiva, ou seja, baseada na culpa do agente, influenciando o Código Civil Alemão, o Código Civil Suíço, bem como o Código Civil Brasileiro de 1.916 ${ }^{58}$ : “Art. 1.382 - tout fait quelconque de l'homme, que cause à autri un dommage, oblige celui par la faute duquel il est arrivé, à le réparer"59.

As obrigações oriundas dos atos ilícitos têm origem nas ações culposas ou dolosas dos agentes públicos; essas ações são praticadas com infração a um dever de conduta e resultam em dano a outrem. Nesse diapasão, surge o dever de indenizar ou restituir o prejuízo causado.

A trajetória da responsabilização do Estado foi delineada graças às decisões proclamadas pela jurisprudência do contencioso administrativo francês, denominadas arrêts (precedentes).

A Responsabilidade do Estado ou Responsabilidade Pública, conforme menciona Álvaro Lazzarini ${ }^{60}$, nasceu praticamente ombreada ao Direito Administrativo, a partir da famosa decisão no caso Blanco, proferida em $1^{\circ}$ de fevereiro de 1873 , relatado pelo

\footnotetext{
${ }^{57}$ PEREIRA, Caio Mário da Silva. Responsabilidade Civil - De acordo com a Constituição de 1988. Rio de Janeiro: Forense, 1996. p. 1.

${ }^{58}$ GIORDANI, José Acir Lessa. A Responsabilidade Civil Objetiva Genérica no Código Civil de 2002. 2. ed. Rio de Janeiro: Lumen Juris, 2007. p.9.

${ }^{59}$ Qualquer fato originado daquele que provoca um dano a outrem obriga aquele que foi a causa do que ocorreu a reparar este dano (tradução livre).
}

${ }^{60}$ LAZZARINI, Álvaro. Estudos de Direito Administrativo,.2. ed. São Paulo: Revista dos Tribunais, 1999. p. 418. 
Conselheiro David. A menina Agnés Blanco perdeu as pernas depois de ter sido atropelada por vagonete da Companhia Nacional de Manufatura de Fumo que trafegava pelos trilhos que cortavam a cidade francesa de Bordeaux, transportando matéria-prima de um edifício para outro.

O pai da menina ajuizou ação indenizatória, fundamentando sua pretensão na responsabilidade civil do Estado por prejuízos causados a terceiros perante o Tribunal Judiciário Comum. No referido caso, o Tribunal de Conflitos entendeu que era de competência do Tribunal Administrativo por tratar-se de hipótese de responsabilidade resultante do funcionamento de um serviço público. A partir daí, consagrou-se, definitivamente, a teoria publicística. Apesar de o "Caso Blanco" ser considerado um divisor de águas entre a concepção privatística e o entendimento publicístico, outra decisão que apontava para o mesmo sentido foi aquela conhecida como o Caso Rotschild, datada de 6 de dezembro de 1.855 , muito embora não tenha tido a mesma repercussão.

As conclusões de José Cretella Júnior ${ }^{61}$ dão conta de que:

As decisões do Conselho de Estado e do Tribunal de Conflitos demonstram, como na sequência de um filme, toda a evolução da responsabilidade administrativa, a partir do caso inicial - Rotschild, 1855, que consagra a tese do Estado devedor -, passando pelo célebre Caso Blanco, 1873, que consagra a tese da responsabilidade do Estado, em virtude do mau funcionamento de um serviço público.

Cretella Júnior ${ }^{62}$ faz referência, ainda, a outros casos igualmente submetidos ao Conselho de Estado ou ao Tribunal de Conflitos, e que também foram considerados como marcantes de teorias específicas. No Caso Cames (1.895), adotou-se a teoria do risco profissional na hipótese de acidente no serviço público;

i) No processo que envolveu o Caso Anguet (1.911), ocorreu que o administrado, ao sair pelas portas do fundo do Departamento de Correios, em decorrência do fechamento indevido da porta da frente, foi expulso por dois carteiros que o tomam por intruso, cai e quebra a perna, a partir daí estabeleceu-se a distinção entre culpa do serviço e culpa pessoal do agente;

ii) No caso Pelletier (1.873) discutiu-se a falta pessoal e a falta do serviço que a partir desse processo tornou-se bem clara; o episódio envolveu o jornalista Pelletier que editara o primeiro número de seu jornal, no entanto a edição foi interceptada por ordem do

\footnotetext{
${ }^{61}$ CRETELLA Jr., José. O Estado e a Obrigação de Indenizar. 2. ed. Rio de Janeiro: Forense. p. 94-95.

${ }^{62}$ Idem. Ibidem. p. 87-94.
} 
General Louis de Ladmirault e pelo Prefeito de Oise, sob o argumento de que aquele Departamento estava em estado de sítio e que estes agiam no exercício do Poder de Polícia. O jornalista moveu ação responsabilizando pessoalmente o General e o Prefeito;

iii) O episódio referenciado como o caso Lémonnier (1.918), em que se concluiu pela responsabilização da Comuna, na hipótese em que uma Senhora (Lémonnier) foi atingida por uma bala perdida oriunda de uma competição de tiro que ocorreu durante uma festa comemorativa da Comuna, o Prefeito já havia sido alertado do perigo que se constitua em permitir aquele tipo de evento, que criava situação de risco e insegurança para as pessoas que passavam pela Avenida;

iv) Naquele conhecido como o caso Couitéas (1.923), o Estado foi condenado por descumprimento de sentença judicial, em fase de execução; o episódio envolveu o rico proprietário de terras na Tunísia que adquirira extensa gleba de área ocupada por tribos indígenas; muito embora tenha conseguido na Justiça o direito de tomar posse de sua propriedade, o Governo recusou-se a dar cumprimento à sentença, sob o argumento de que a recusa feria interesse geral e, considerando que o sacrificado em prol de interesse geral tem direito à compensação pecuniária, o Estado foi condenado a indenizá-lo;

v) No caso Verbanck (1.933), o Estado foi responsabilizado pelo mau funcionamento do serviço público, que resultou na morte de um cidadão, consagrando a teoria do serviço público. Tratava-se de um caminhão de serviço público (serviço de pontes e calçadas) que, ao dobrar inesperadamente para a esquerda, atropelou e matou um ciclista;

vi) No caso Terrier (1.903), restou imposta à Administração, a responsabilização por promessa pública de recompensa descumprida, na hipótese de serviço público, de fato. Em um determinado Departamento houve uma invasão de serpentes; o Conselho Geral ofereceu recompensa por cada cabeça do réptil que fosse apresentada às autoridades administrativas locais, e o empenho dos caçadores foi tão grande que logo exauriu os cofres públicos. O caçador Terrier pleiteou a respectiva recompensa, entretanto não recebeu o pagamento correspondente, mesmo depois de satisfeitas todas as exigências. O Conselho de Estado, reconhecendo como devida a responsabilização, pois quando prometeu o prêmio, a Administração criou de fato o serviço de extinção de animais daninhos.

vii) No evento que denominou-se como o caso Barco de Eloka (1.921), responsabilizou-se o Estado por danos causados por empresa prestadora de serviços industriais. O fato ocorreu na antiga colônia francesa da Costa do Marfim, que explorava serviços de transporte coletivo de pessoas e carros, de uma para outra margem da lagoa de Eloka. Certa ocasião, o barco tombou, causando danos pessoais e materiais a várias pessoas. 
O proprietário de um caminhão perdido no acidente ajuizou ação pleiteando perdas e danos, contra o Estado.

viii) E ainda, o caso Feutry (1.908), no qual o Estado foi responsabilizado pelos danos causados por demente que se evadiu de hospital público e ateou fogo em pilhas de feno colocadas em frente de uma casa, provocando danos materiais suportados pelo proprietário; a culpa in vigilando foi o fundamento para a imposição de responsabilização.

A contribuição da doutrina francesa foi inestimável para a evolução da responsabilização do Estado; sua aplicação ao caso concreto, bem como a repercussão de seus efeitos no mundo dos fatos e no universo jurídico foram determinantes para alcançar o estágio atual.

\subsubsection{A evolução da responsabilidade do estado no Brasil}

No Brasil, inicialmente, durante o período colonial e na fase seguinte em que a família real mudou-se para o país, e o Rei Dom João VI elevou-o de colônia para reino, prevalecia a irresponsabilidade do Estado pelos danos causados pelos agentes da Coroa Portuguesa $^{63}$.

Durante o período denominado Brasil império, a Constituição de 1.824, nos termos do artigo 99, eximia o Imperador de responsabilidade, entretanto o artigo 179, inciso XXIX, previa a responsabilização dos agentes públicos, conforme descrito:

Art. 99 - a pessoa do Imperador é inviolável, e Sagrada: Ele não está sujeito a responsabilidade alguma.

Art. $179-$

XXIX - os empregados públicos são estritamente responsáveis pelos abusos, e omissões praticadas no exercício das suas funções, e por não fazerem efetivamente responsáveis os seus subalternos.

A Constituição Imperial faz referência direta apenas à responsabilização do agente público, contudo havia legislação específica que previa a responsabilização estatal, firmada em várias leis e Decretos, como por exemplo, o Decreto 1.930, de 26 de abril de 1.857, sobre

\footnotetext{
${ }^{63}$ Marcelo Meireles Lobão afirma que o Direito Brasileiro não vivenciou a fase sombria da infalibilidade do soberano, com o que não podemos concordar, pois o artigo 99 é taxativo em exonerar o Imperador de qualquer responsabilidade ou dever de reparação. In: LOBÃO, Marcelo Meireles. Responsabilidade do Estado pela Desconstituição de Contratos Administrativos em Razão de Vícios de Nulidade. São Paulo: Malheiros, 2008. p.20.
} 
estradas de ferro, e o 3.453 , de 20 de abril de 1.865, que dispõe sobre oficiais de registro, entre outros. ${ }^{64}$

Com a proclamação da República, a mudança na forma de governo exigiu a promulgação de uma nova Carta Constitucional, contudo a Carta Magna de 1.891 não fez avançar a matéria, conforme se percebe no seu artigo 82:

Art. 82 - Os funcionários públicos são estritamente responsáveis pelos abusos e omissões em que incorrerem no exercício de seus cargos, assim como pela indulgência ou negligência em não responsabilizarem efetivamente os seus subalternos.

Parágrafo único - O funcionário público obrigar-se-á, por compromisso formal, no ato da posse, ao desempenho dos seus deveres.

O declínio das oligarquias agrárias, que durante a República Velha se alternavam no poder, foi determinante para a reestruturação do Estado Brasileiro, e foi nesse contexto que o Código Civil de 1.916 (Lei 3.071/16) entrou em vigor. O artigo 15 tornou, então, expressa a responsabilidade extracontratual do Estado, entretanto exigia-se a demonstração de culpa, nos seguintes termos:

Art. 15 - As pessoas jurídicas de direito público são civilmente responsáveis por atos de seus representantes que, nessa qualidade, causem danos a terceiros, procedendo de modo contrário ao Direito ou faltando a dever prescrito em lei, salvo o direito regressivo contra os causadores do dano.

A marcha constante do tempo fez com que o instituto da responsabilização estatal evoluísse à categoria de norma constitucional no bojo da Carta Magna de 1.934, inaugurando o sistema de responsabilidade solidária, conforme segue:

Art. 171- Os funcionários públicos são responsáveis solidariamente com a Fazenda Nacional, Estadual, Municipal, por quaisquer prejuízos decorrentes de negligência, omissão ou abuso no exercício de seus cargos.

$\S 1^{\circ}$ - Na ação proposta contra a Fazenda Pública, e fundada em lesão praticada por funcionário, este será sempre citado como litisconsorte.

$\S 2^{\circ}$ - Executada a sentença contra a Fazenda, esta promoverá a execução contra o funcionário culpado.

A Constituição Federal de 1.937 manteve a noção de responsabilidade solidária, excluindo apenas os dois parágrafos da Constituição anterior.

Art. 158 - Os funcionários públicos são responsáveis solidariamente com a Fazenda Nacional, estadual ou municipal, por quaisquer prejuízos decorrentes de negligência, omissão ou abuso no exercício dos seus cargos.

\footnotetext{
${ }^{64}$ ARAUJO. Edmir Netto de. Curso de Direito Administrativo. 5. ed. São Paulo: Saraiva, 2010. p.786.
} 
No Brasil, o ordenamento jurídico inicialmente inclinou-se para a doutrina subjetiva da responsabilidade do Estado, entretanto o advento da Constituição de 1.946 convergiu para a responsabilidade objetiva. "Desde o império, nossos juristas mais avançados propugnavam pela adoção da responsabilidade sem culpa, fundada na teoria do risco que se iniciava na França, entretanto confrontavam os civilistas apegados à teoria da culpa, reinante no Direito Privado, contudo inadequado para o Direito Público ${ }^{65,}$.

Na realidade, mesmo antes da Constituição Federal de 1.946 - marco regulatório da teoria objetiva, juristas de alta envergadura como Rui Barbosa ${ }^{66}$ defendiam a responsabilidade objetiva do Estado, conforme se observa na manifestação feita por ocorrência do empastelamento do jornal "O Comércio de São Paulo", então dirigido por Afonso Arinos e pertencente a Eduardo Paulo da Silva Prado. Afirmou, naquela ocasião, Rui Barbosa que:

Princípio corrente foi sempre o de que o poder em cujas mãos se ache a autoridade policial responde pelo dano cometido no seu território pelos ajuntamentos armados ou desarmados. Por isso, já a legislação do período revolucionário, na França, nos fins do século passado, estatuía para as comunas essa obrigação, em vigor até hoje, além daquele país, em todos os outros onde a Polícia é municipal, inclusive Inglaterra e Estados Unidos. Em São Paulo, é o Estado que exerce a polícia. A esta, logo, incumbe a responsabilidade pela culpa ativa ou passiva dos seus agentes ${ }^{67}$.

Em 1.943, o Ministro Philadelpho Azevedo afirmou, no STF, em voto que se tornaria histórico, proferido nos autos da Ação Cível no 7.264, de 12 de abril de 1943, que "o problema da responsabilidade civil do Estado ainda não encontrou, entre nós, o terreno sedimentado, em que pudesse descansar, após tormentoso embate na doutrina e na jurisprudência” . O referido voto, no qual Philadelpho Azevedo sustentava a necessidade de indenizar os prejuízos decorrentes de movimentos populares, ensejou a reversão da nossa jurisprudência na matéria, manifestando-se, naquela oportunidade, pela última vez, a mais alta

\footnotetext{
${ }^{65}$ MEIRELLES. Hely Lopes. Direito Administrativo Brasileiro. 37. ed. São Paulo: Malheiros, 2011. p. 700

${ }^{66}$ WALD, Arnoldo. Os Fundamentos da Responsabilidade Civil do Estado. In: Revista de Informação Legislativa, Brasília, ano 30, nº 117, jan/mar 1.993. p. 5.

${ }^{67}$ Obras Completas de Rui Barbosa, ed. Casa de Rui Barbosa, vol. XXV, tomo IV/168, "Trabalhos Jurídicos", e vol. XXVII, 1900, tomo II, 1211, “Trabalhos Jurídicos”, e ainda, ARNOLDO WALD, A Responsabilidade Civil e seus Antecedentes Doutrinários no Direito Brasileiro, In: Revista do Serviço Público, março, 1955, p. 540, apud WALD, Arnoldo. Os Fundamentos da Responsabilidade Civil do Estado. In: Revista de Informação Legislativa, Brasília, ano 30, n 117, jan/mar 1.993. p. 5-6, NOTA DE RODAPÉ.
} 
Corte pela aplicação da teoria da culpa como fundamento exclusivo da responsabilidade do Estado $^{68}$.

Nesse sentido, Hely Lopes Meirelles ${ }^{69}$ assevera que:

Embora insatisfatória a orientação adotada pelo nosso legislador civil para a composição dos danos causados à Administração Pública, permaneceu entre nós a doutrina subjetiva até o advento da Constituição de 1946, que com o disposto no art. 194, acolheu a teoria objetiva do risco administrativo, revogando em parte o art. 15 do CC [...].

Foi a Carta Magna de 1.946 a responsável pela inauguração da responsabilidade objetiva do Estado no ordenamento jurídico brasileiro, nos termos do artigo 194, conforme transcrito:

Art. 194 - as pessoas jurídicas de direito público interno são civilmente responsáveis pelos danos que os seus funcionários, nessa qualidade, causarem a terceiros.

Parágrafo único. Caber-lhes-á ação regressiva contra os funcionários causadores do dano, quando tiver havido culpa destes.

Com a Carta de Magna de 1.946 vigente, naquela época, a $2^{\mathrm{a}}$ Turma do Supremo Tribunal Federal, que tinha como relator o Ministro Orozimbo Nonato ${ }^{70}$, determinou que fosse indenizado o Cotonifício Crespi pelos danos resultantes do bombardeio de São Paulo, na Revolução de 1924. O voto vencedor acolheu a tese anteriormente defendida por Philadelpho Azevedo, nos seguintes termos:

[...] insuficientes e inadequados se mostram os critérios civilísticos da culpa, já repulsados no livro famoso de AMARO CAVALCANTI e veementemente combatidos, neste Tribunal, por PEDRO LESSA. A responsabilidade do Estado deriva de outras fontes: da equidade, das razões de alta política jurídica da alusão de MAURICE HAURIOU, das ideias solidaristas, da distribuição, pelos membros do consórcio civil, dos ônus e dos cômodos.

E elas confluem, no caso, para o reconhecimento da procedência da ação, valendo realçar que a tendência da doutrina e da jurisprudência é para relegar, no caso, os critérios de Direito Civil sobre a culpa e reconhecer a responsabilidade do Estado pelos atos de guerra ${ }^{71}$.

68 WALD, Arnoldo. Os Fundamentos da Responsabilidade Civil do Estado. In: Revista de Informação Legislativa, Brasília, ano 30, nº 117, jan/mar 1.993. p. 7.

${ }^{69}$ MEIRELLES. Hely Lopes. Direito Administrativo Brasileiro. 37. ed. São Paulo: Malheiros. 2011. p.701-702.

${ }^{70}$ LEAL, Roger Stiefelmann. Memória Jurisprudencial: Ministro Orozimbo Nonato. Brasilia: Supremo Tribunal Federal, 2007.

71 WALD, Arnoldo. Os Fundamentos da Responsabilidade Civil do Estado. In: Revista de Informação Legislativa, Brasília, ano 30, $\mathrm{n}^{\circ} 117$, jan/mar 1.993. p. 7-8. 
A Lei Maior promulgada em 1.967 e mantida em 1.969 suprimiu o termo “civilmente" e "interno", promovendo o alargamento no conceito de responsabilização.

Art. 105 - As pessoas jurídicas de direito público respondem pelos danos que os seus funcionários, nessa qualidade, causem a terceiros.

Parágrafo único - Caberá ação regressiva contra o funcionário responsável, nos caso de culpa ou dolo.

$\mathrm{Na}$ parte Geral do Código Civil Brasileiro vigente, nos artigos 186 a 188, encontra-se esculpida a regra geral de responsabilidade aquiliana e algumas excludentes. $\mathrm{Na}$ parte Especial, mais especificamente no artigo 389, está sedimentada a regra básica de responsabilidade contratual, e ainda no bojo do título "Da Responsabilidade Civil", observase a presença de capítulo específico sobre a obrigação de reparar, e outro acerca da indenização (arts. 927 e seguintes).

O alargamento da responsabilização das pessoas jurídicas de direito público acentuou-se com a extensão da responsabilização por danos causados a terceiros às pessoas jurídicas de direito privado, prestadoras de serviços públicos; trata-se de inovação extremamente importante trazida pela Constituição Federal de 1.988, artigo 37, $\S 6^{\circ}$ :

Art. 37-

$\S 6^{\circ}$ - As pessoas jurídicas de direito público e as de direito privado prestadoras de serviços públicos responderão pelos danos que seus agentes, nessa qualidade, causarem a terceiros, assegurado o direito de regresso contra o responsável nos casos de dolo ou culpa.

Repita-se, a responsabilidade civil do Poder Público na Constituição Federal de 1.988 está consagrada em seu artigo $37, \S 6^{\circ}$, que adotou a chamada teoria do risco administrativo. Note-se que temos incluídas as pessoas jurídicas de direito privado prestadoras de serviços públicos, não abrangidas pelo art. 43, do Código Civil de 2.002.

Reportando-nos a Hely Lopes Meirelles ${ }^{72}$,

o $\S 6^{\circ}$ do artigo 37 da Constituição Federal seguiu a linha traçada nas Constituições anteriores e, abandonando a privatística teoria subjetiva da culpa, orientou-se pela doutrina do Direito Público e manteve a responsabilidade civil objetiva da Administração, sob a modalidade do risco administrativo. Não chegou, porém, aos extremos do risco integral. É o que se infere do texto constitucional e tem sido admitido reiteradamente pela jurisprudência, com apoio na melhor doutrina.

\footnotetext{
${ }^{72}$ MEIRELLES, Hely Lopes. Direito administrativo brasileiro. 37. ed. São Paulo: Malheiros, 2011. p. 702.
} 
Podemos afirmar que a noção de responsabilidade objetiva atualmente é acolhida por todas as Nações modernas, não mais subsistindo a intangibilidade do Estado em face de sua supremacia e superioridade em relação ao administrado ${ }^{73}$.

\subsection{RESPONSABILIDADE EXTRACONTRATUAL DO ESTADO}

A responsabilização do Estado se estende sobre todas as hipóteses em que o Estado tem o dever de reparar os eventos danosos oriundos da conduta lícita ou ilícita de seus agentes. Os fundamentos estão situados na culpa (responsabilidade subjetiva) e no risco (responsabilidade objetiva).

Sob outro prisma, a responsabilidade, pública ou privada, também pode ser classificada em contratual ou extracontratual. A responsabilidade contratual é originada no inadimplemento de cláusulas estabelecidas em pactos convencionais aceitas por ambas as partes, sendo objeto específico de estudo no âmbito do Código Civil Brasileiro de 2.002, nos termos dos arts. 389 e seguintes. Dessa forma, uma vez firmado o contrato, o descumprimento de quaisquer cláusulas impõe a respectiva reparação. Entretanto, a responsabilidade contratual não será tratada na presente dissertação.

\subsubsection{Elementos para a caracterização da responsabilidade estatal}

\subsubsection{Conduta lesiva que enseja reparação}

A conduta se traduz pela atitude do agente, ou seja, o comportamento humano, comissivo ou omissivo, voluntário e imputável.

A Carta Constitucional, pelo menos em cinco momentos diferentes, faz referência a hipóteses de ocorrência de danos e suas consequências, ou seja, à conduta lesiva que impõe a reparação:

\footnotetext{
${ }^{73}$ MADEIRA. José Maria Pinheiro. Administração Pública. TOMO II. 11. ed. Rio de Janeiro: Elsevier, 2010. p. 252.
} 
Art. $21-$

XXIII -

d) a responsabilidade civil por danos nucleares independe da existência de culpa. ${ }^{74}$

Art. 37

$\S 6^{\circ}$ - As pessoas jurídicas de direito público e as de direito privado prestadoras de serviços públicos responderão pelos danos que seus agentes, nessa qualidade, causarem a terceiros, assegurado o direito de regresso contra responsável nos casos de dolo ou culpa.

Art. 136-

$\S 1^{\circ}-$

II - ocupação e uso temporário de bens e serviços públicos, na hipótese de calamidade pública, respondendo a União pelos danos e custos decorrentes.

Art. 225 -

$\S 3^{\circ}$ - As condutas e atividades consideradas lesivas ao meio ambiente sujeitarão os infratores, pessoas físicas ou jurídicas, a sanções penais e administrativas, independentemente da obrigação de reparar os danos causados ${ }^{75}$.

Não obstante os dispositivos constitucionais supracitados, é no artigo $5^{\circ}$ que a Constituição garante o neminem laedere, protegendo os direitos da personalidade, na medida em que impõe a inviolabilidade do direito à vida, à liberdade, à igualdade, à segurança e à propriedade.

\subsubsection{A responsabilidade do Estado por atos lícitos}

Frequentemente entende-se por Responsabilidade Extracontratual do Estado o dever que lhe incumbe de indenizar os danos lesivos à esfera jurídica garantida de outrem e que lhe sejam imputáveis em virtude de conduta unilateral comissiva ou omissiva. Entretanto, essa intepretação não afasta a hipótese de o Estado ser responsabilizado quando este houver praticado ato lícito. A denominada responsabilidade por atos lícitos constitui na obrigação de reparar o dano causado por uma conduta legalmente autorizada.

\footnotetext{
${ }^{74}$ Nessa hipótese, verificamos a presença da teoria do risco integral.

${ }^{75}$ Nessa situação, observamos a hipótese de Responsabilidade Penal da Pessoa Jurídica.
} 
Todas as vezes que a prática de um ato lícito pelo ente Estatal resultar lesão a um direito alheio, sendo os danos anormais, o Estado deverá responder, motivando a recomposição do equilíbrio rompido diante da atuação estatal.

O Estado, em sentido amplo, na qualidade de pessoa jurídica de direito público, está obrigado a praticar diversos atos objetivando o pleno e regular funcionamento da máquina administrativa, além de proporcionar à coletividade os serviços públicos necessários ao seu bem-estar. Nesse contexto, sendo o Estado sujeito de direitos e obrigações, em decorrência do desempenho de suas funções, ocasionalmente, poderá provocar prejuízos a terceiros, hipótese em que, em face da lei, resulta na obrigação de reconstituir os agravos patrimoniais oriundos de sua ação ou omissão motivadora da lesão ${ }^{76}$.

Para Jean Rivero ${ }^{77}$, “O Estado, mesmo o democrático, pode lesar e prejudicar. Administrar é descontentar”. Nas hipóteses de danos advindos de práticas lícitas, é necessário, além das características decorrentes da atividade ilícita, que haja a demonstração de sua especialidade e de sua anormalidade (excedente aos inconvenientes inerentes ao funcionamento de um serviço público).

Portanto fica excluída a obrigação do Estado de indenizar em virtude de atos lícitos lesivos quando não demonstrada a especialidade e a anormalidade, uma vez que, em tal circunstância, o ato danoso situa-se no limite de tolerância decorrente da vida em comunidade.

Dessa forma, a conduta lesiva do Estado pode se manifestar em duas acepções: quando não observa os limites fixados pela lei, ocasionando a ocorrência de atos ilícitos, ou então, muito embora no regular desempenho de suas atividades, visando ao interesse público e, ainda, cumprindo integralmente o comando legal, acaba por gerar danos.

Importante destacar que não é qualquer ato lícito praticado pelo Estado motivador de indenização, mas sim o ato lícito danoso.

Para José Joaquim Gomes Canotilho:

Acto lícito danoso na sua caracterização tradicional é aquele que, de um modo voluntário e final, se dirige à produção de um dano na esfera jurídica de outrem: o agente lesante tem a certeza, consciência e vontade de causar um prejuízo ${ }^{78}$.

\footnotetext{
${ }^{76}$ TRUJILLO, Élcio. Responsabilidade do Estado por Atos Lícitos. São Paulo: LED Editora de Direito, 1997. p. 17.

${ }^{77}$ RIVERO, Jean. Curso de Direito Administrativo Comparado. Tradução José Cretella Jr. 2. ed. São Paulo: Revista dos Tribunais, 2004. p. 165.

78 CANOTILHO, José Joaquim Gomes. O Problema da Responsabilidade por Actos Lícitos. Coimbra: Almedina, 1974. p. 79-80.
} 
Também as doutrinas italiana e germânica destacam a voluntariedade e a consciência como características do ato lícito danoso, conforme sustenta Giovani Duni ${ }^{79}$, para quem "quando se fala da responsabilidade por atos lícitos, entende-se a obrigação de reparar o dano que se é autorizado a produzir ainda com a certeza, consciência e vontade que uma certa ação possa causá-lo" .

Gomes Canotilho ${ }^{80}$, referindo-se, também, às doutrinas germânica e italiana, oferece como exemplo Forsthoff, Verwaltungsrecht: “[...] Os casos de danos que foram apresentados (aufopferung e Enteignung) têm todos um ponto comum: supõem um acto do Estado que é dirigido consciente e voluntariamente (wissentlich und willentlich) contra os direitos patrimoniais do indivíduo".

Deste modo, o dano perpetrado é, na responsabilidade por atos lícitos, um elemento inseparável da ação, sendo tradicionalmente caracterizado como aquele que de "um modo voluntário e final, se dirige à produção de um dano na esfera jurídica de outrem: o agente lesante tem a certeza, consciência e vontade de causar um prejuízo ${ }^{81}$.

Pois bem, a prática de ato lícito pode, ocasionalmente, resultar em dano; a doutrina considera esse evento como dano lícito indenizável, desde que presentes quatro requisitos para sua configuração, conforme descritos:

a) O dano lícito deve ser um dano jurídico e não somente um dano mensurável economicamente, ou seja, havendo lesão à esfera juridicamente protegida e economicamente mensurável, haverá indenização. Ressalte-se que nem todo dano juridicamente reparável é de natureza patrimonial, mormente diante do dano moral que, muito embora seja de natureza extrapatrimonial, também é objeto de ressarcimento em forma de pecúnia.

b) $O$ dano lícito deve ser certo e determinável, pois não há como reparar uma lesão sem a convicção de sua ocorrência; ainda que sua deflagração concreta não tenha se apresentado, o fato de os efeitos concretos do dano não haverem se configurado não afasta a certeza de sua ocorrência.

\footnotetext{
${ }^{79}$ DUNI, Giovani. Lo Stato e la responsabilitá patrimoniale. Milano: Dott A. Giuffré, 1968. p. 78 apud TRUJILLO, Elcio. Responsabilidade do Estado por Atos Lícitos. São Paulo: LED Editora de Direito, 1997. p. 98.

${ }^{80}$ CANOTILHO, José Joaquim Gomes. O Problema da Responsabilidade por Actos Lícitos. Coimbra: Almedina, 1974. p. 80, nota 23.

${ }^{81}$ CANOTILHO, José Joaquim Gomes. O Problema da Responsabilidade por Actos Lícitos. Coimbra: Almedina, 1974. p. 80.
} 
c) $O$ dano lícito deve ser especial, ou seja, a lesão a direito deve ser experimentada por um número restrito de indivíduos em contrapartida pelo benefício usufruído por toda a coletividade.

d) $O$ dano lícito deverá incidir de modo anormal, isto é, a lesão deve ser proporcionalmente maior que os encargos considerados normais na vida social cotidiana. Entretanto, a grande dificuldade reside no fato de se estabelecer o que é considerado um encargo normal ou suportável, e o que pode ser classificado como um encargo excessivo.

Com o objetivo de elucidar de forma mais eficiente tais conceitos, valemo-nos do exemplo apontado por Celso Antônio Bandeira de Mello, referindo-se a atos jurídicos lícitos, "a determinação de fechamento legítimo e definitivo do perímetro central da cidade a veículos automotores, acarretando prejuízos aos proprietários e edifícios-garagem, devidamente licenciados". Quanto aos atos materiais lícitos, o autor utiliza o exemplo extraído da obra de Osvaldo Aranha Bandeira de Mello, que exemplifica o nivelamento de uma rua que, por características físicas ambientais, faz com que algumas casas fiquem em nível mais baixo ou mais elevado, em relação ao leito carroçável, tendo como consequência a desvalorização do imóvel ${ }^{82}$.

Conforme mencionado no tópico que trata de responsabilidade e sacrifício de direito, autores como Maurício Zuckon ${ }^{83}$ sustentam que o dano lícito indenizável decorre de hipótese tipificadora de sacrifício de direito. Contudo, em nossa opinião, o dano lícito também pode ocorrer em hipóteses em que o Estado, ainda que praticando ato lícito, cause lesão na esfera juridicamente protegida, sem, necessariamente, tal hipótese estar enquadrada em sacrifício do direito.

Em nosso entendimento, a responsabilidade por atos lícitos não se restringe apenas aos atos jurídicos, excluindo os demais atos que não sejam dirigidos à produção de efeitos num caso concreto. Desse modo, os atos materiais, ou melhor, as operações materiais da administração, podem causar danos que lhes são inerentes. Nesse contexto, verifica-se que "além de atividade, coisas ou serviços excepcionalmente perigosos, criadores de situações propícias à causação de danos, outros fatos lícitos, representados pelas obras e trabalhos

\footnotetext{
${ }^{82}$ BANDEIRA DE MELLO, Celso Antônio. Curso de Direito Administrativo. 28. ed. São Paulo: Malheiros, 2011. p. 1.004 .

${ }^{83}$ ZOCKUN, Maurício. Responsabilidade Patrimonial do Estado. São Paulo: Malheiros, 2010. p. 107.
} 
públicos, que podem trazer resultados danosos inexigíveis aos cidadãos sem a devida reparação da lesão" ${ }^{\prime 84}$.

Comungando da opinião de Zanobini ${ }^{85}$, José Cretella Júnior também entende o ato lícito como idôneo para gerar a responsabilidade da administração, porém refuta o uso da expressão "responsabilidade do Estado por atos legítimos", ao afirmar que esta expressão “com sua inegável contradição terminológica demonstra quão amplamente a responsabilidade publicística se afasta da comum, fundada exclusivamente na liceidade do dano".

Lúcia Vale Figueiredo também assevera que se a administração, ao cumprir suas funções, suas competências-deveres, lesar o administrado, responderá por ato lícito, sob o fundamento do princípio da igualdade, afinal, "se todos são iguais perante a lei, também o devem ser no tocante às cargas públicas ${ }^{86}$."

Há doutrinadores que não admitem o ato lícito como gerador da obrigação de indenizar por parte do Estado. Aldo Bozzi é um dos autores que não acata a responsabilidade por ato legítimo, pois de acordo com seu entendimento, “a noção de responsabilidade, pelo menos no sentido tradicional, é impropriamente invocada, seja porque a responsabilidade pressupõe um fato ilegítimo ou ilícito em, portanto, um damnum injuria datum, jurídico e não apenas econômico ${ }^{87}$."

Marçal Justen Filho considera que um ato jurídico que seja conforme o direito, praticado de maneira regular e perfeito, não deve admitir a responsabilização civil, exceto quando essa for opção explícita de uma lei, como por exemplo, a ocorrência de atentado terrorista (Lei Federal n ${ }^{\mathrm{o}} 10.744$ de outubro de 2.003$)^{88}$.

\footnotetext{
${ }^{84}$ CANOTILHO. José Joaquim Gomes. O Problema da Responsabilidade por Actos Lícitos. Coimbra: Almedina, 1974. p. 137. O autor afirma que não há o que distinguir entre atos jurídicos e operações materiais, ou atos voluntariamente dirigidos à imposição de sacrifícios e atos lícitos de que acidentalmente resultam prejuízos, e até mesmo ação ou omissão.

${ }^{85}$ ZANOBINI, Guido. Corso di Diritto Amnistrativo. 6. ed. Milão: A. Giuffre, 1950, vol. . p. 278 apud CRETELLA JÚNIOR, José. O Estado e a Obrigação de Indenizar. Rio de Janeiro: Forense, 2002. p. 100.

${ }^{86}$ FIGUEIREDO, Lúcia Valle. Curso de Direito Administrativo. 7. ed. São Paulo: Malheiros, 2004. p. 261.

${ }^{87}$ BOZZI, Aldo. Instituzioni di Diretto Pubblico. 2. ed. Milão: Dott. A. Giuffré-Editore, 1966. p. 337 apud CRETELLA JÚNIOR, José. O Estado e a Obrigação de Indenizar. Rio de Janeiro: Forense, 2002. p. 101.

${ }^{88}$ JUSTEN FILHO, Marçal. Curso de Direito Administrativo. São Paulo: Saraiva, 2005. p. 798.
} 


\subsubsection{O dano indenizável}

Para que haja a concretização da responsabilidade, tanto no âmbito público quanto no privado, é exigível a consumação efetiva do dano, ou seja, a lesão, prejuízo ou ofensa causada ao bem ou direito, ou, ainda, ao conjunto de valores juridicamente tutelados, podendo sobrevir sob a forma de material, moral ou à imagem.

Conforme ensina Antonio Jeová Santos ${ }^{89}$,

Dano é prejuízo. É diminuição de patrimônio em detrimento a afeições legítimas. Todo ato que diminua ou cause menoscabo aos bens materiais ou imateriais, pode ser considerado dano. O dano é um mal, um desvalor ou contravalor, algo que se padece com dor, posto que nos diminui e reduz; tira de nós algo que era nosso, do qual gozávamos ou nos aproveitávamos, que era nossa integridade psíquica ou física, as possibilidades de acréscimo ou novas incorporações.

Yussef Said Cahali ${ }^{90}$ pondera que, pelo entendimento generalizado da doutrina e consagrado nas legislações, é possível distinguir, de um lado, a categoria dos danos patrimoniais, o verdadeiro e próprio prejuízo econômico; e de outra banda, os danos extrapatrimoniais ou morais, que se consubstanciam pelo sofrimento psíquico ou moral, as dores, as angústias e as frustrações infligidas ao ofendido.

No que tange à responsabilidade civil privada, o artigo 927 do Código Civil Brasileiro vigente - Lei 10.046/2001 - estabelece que:

Art. 927 - Aquele que, por ato ilícito (arts. 186 e 187), causar dano a outrem, fica obrigado a repará-lo.

Parágrafo único. Haverá obrigação de reparar o dano, independentemente de culpa, nos casos especificados em lei, ou quando a atividade normalmente desenvolvida pelo autor do dano implicar, por sua natureza, risco para os direitos de outrem.

A evidência do dano é um dos elementos indispensáveis para a configuração da responsabilização do Estado. Segundo Alexandre de Moraes ${ }^{91}$, a indenização do dano deve alcançar o que a vítima efetivamente perdeu, aquilo que ela gastou, e o que deixou de ganhar em consequência direta e imediata do ato lesivo da administração, isto é, deverá o prejudicado

\footnotetext{
${ }^{89}$ SANTOS, Antônio Jeová. Dano Moral Indenizável. 2. ed. São Paulo: Lejus, 1999. p. 71.

${ }^{90}$ CAHALI, Yussef Said. Dano Moral. 4. ed. São Paulo: Revista dos Tribunais, 2011. p. 18.

${ }^{91}$ MORAES, Alexandre de. Direitos Humanos Fundamentais. 9. ed.São Paulo: Atlas, 2011. p. 239.
} 
ser indenizado nos prejuízos emergentes nos lucros cessantes, bem como pelos honorários advocatícios, e com correção monetária e juros de mora, na hipótese de atraso do pagamento.

A reparação de lesões ou prejuízos causados a terceiros pode ser realizada na esfera administrativa, desde que a Administração reconheça imediatamente sua responsabilidade e haja concordância entre as partes sobre o valor montante da indenização, sem que demanda seja necessariamente submetida à apreciação do Judiciário.

As indenizações por dano material e por dano moral podem ser cumuladas, conforme pacificado pelo Superior Tribunal de Justiça por meio da Súmula 37, nos seguintes termos: "Súmula 37 - são cumuláveis as indenizações por dano material e por dano moral oriundas do mesmo fato."

Não se pode desconsiderar que o dano, para ser indenizável, deve ser certo e atual ou futuro (o resultado danoso pode ser futuro, não o fato que ocasionou o dano), isto é, os efeitos do episódio danoso recaem sobre o patrimônio atual do administrado, determinando sua diminuição, ou então sobre seu patrimônio futuro (como por exemplo: direitos, rendimentos etc.), impossibilitando ou minimizando os benefícios a que o lesado teria direito ou pretensão de ter.

Quanto aos danos emergentes e prejuízos futuros ou lucros cessantes, podemos afirmar que o primeiro refere-se à lesão atual efetivamente suportada, entretanto há casos em que, além do prejuízo imediato, o ofensor também deverá arcar com aquilo que o lesado deixou de ganhar durante certo tempo, correspondendo aos chamados frutos que seriam produzidos no futuro se não houvesse a deterioração da fonte produtora. Exemplo clássico é aquele envolvendo acidente automobilístico com veículo utilizado como táxi ou caminhão de cargas.

Quanto à natureza dos danos, estes podem ser classificados como morais, materiais e pessoais, bem como também aqueles causados em decorrência das relações de consumo, que surgiram a partir do advento do Código de Defesa do Consumidor inserido pela Lei 8.078, de 11 de setembro de 1990, no ordenamento jurídico brasileiro. 


\subsection{Dano moral}

A possibilidade de reparação por prejuízos sofridos de natureza moral foi admitida somente após o advento da Constituição Federal de 1988; até então, a matéria era objeto de grandes divergências doutrinárias e jurisprudenciais.

De acordo com José Maria Pinheiro Madeira ${ }^{92}$,

No que tange ao dano moral, devemos acrescentar que este está atrelado aos direitos da personalidade do indivíduo, e que a indenização objetiva reparar, ainda que não totalmente, uma dor sofrida no campo moral, no íntimo do ser. Por isso, o seu valor não é mensurável como o dano material, pois impossível seria medir a dor de alguém, em determinada circunstância de uma perda.

No Brasil, não há mais discussões ou dúvidas sobre o cabimento de indenização decorrente de agravo moral, aliás, nos dias atuais não cabe mais interpretação diversa sobre o tema.

Ao cotejar o artigo $5^{\circ}$, inciso X, da Constituição Federal vigente, podemos ter a falsa impressão de que o texto legal teve a intenção de tipificar o instituto do dano moral unicamente nas hipóteses ali elencadas, ao afirmar que são invioláveis a intimidade, a vida privada, a honra e a imagem das pessoas, assegurando o direito à indenização pelo dano material ou moral decorrente dessa violação. Entretanto, importante atentar para o fato de que o rol não é taxativo, mas apenas meramente exemplificativo.

A hermenêutica, nessa seara, deve ser aplicada tomando como base todo o texto e não levando em conta apenas uma interpretação setorizada, excluindo a possibilidade de reparação nas hipóteses de fora do referido dispositivo constitucional. Em outros dispositivos, podemos vislumbrar hipóteses de dano puramente moral, como por exemplo: a proibição de tortura, tratamento degradante ou desumano (art. $5^{\circ}, \mathrm{III}$ ); o respeito à incolumidade física e moral do preso (art. $5^{\circ}$, XLIX); a inviolabilidade do sigilo de correspondência, comunicações telegráficas, dados e comunicações telefônicas etc.

O dano moral, conforme a nova disciplina constitucional, pode permear vários aspectos, como os de imagem, vida privada, intimidade, reputação, honra, morte de familiares, autoria de obras científicas e artísticas etc.

Antônio Jeová Santos ${ }^{93}$ considera que:

${ }^{92}$ MADEIRA, José Maria Pinheiro. Administração Pública. TOMO II. 11. ed. Rio de Janeiro: Elsevier, 2010. p. 270. 
[...] Nenhuma ofensa proferida pode ficar isenta de reparação. Num sistema que coloca o homem como epicentro do Direito, o reconhecimento do dano moral, como entidade passível de gerar indenização, é o coroar do reconhecimento dos direitos da personalidade. Reconhecida está, também, a possibilidade de reclamo que será transformado em certo montante em dinheiro.

Importante esclarecer, ainda, que a reparação por danos morais é cabível tanto em relação à pessoa física quanto em relação à pessoa jurídica e até mesmo em relação à coletividade, compreendendo os interesses coletivos ou difusos. A Súmula 227 do Superior Tribunal de Justiça assegura que "A pessoa jurídica pode sofrer dano moral".

A propósito, em publicação da "Revista do Advogado" (AASP) de n 44, sobre "Responsabilidade Civil”, há interessante artigo sobre "Reparação Civil Por Danos Morais" de lavra do Desembargador Carlos Alberto Bittar ${ }^{94}$, que confirma a atual posição de nossos Tribunais a respeito da matéria:

[...] Danos morais são, conforme anotamos alhures, lesões sofridas pelas pessoas, físicas ou jurídicas, em certos aspectos de sua personalidade, em razão de investidas injustas de outrem. São aqueles que atingem a moralidade e a efetividade da pessoa, causando-lhe constrangimentos, vexames, dores, enfim, sentimentos e sensações negativas. Contrapõem-se aos danos denominados materiais, que são prejuízos suportados no âmbito patrimonial do lesado. Mas podem ambos conviver, em determinadas situações, sempre que os atos agressivos alcançam a esfera geral da vítima, como, dentre outros, nos casos de morte de parente próximo em acidente, ataque à honra alheia pela imprensa, violação à imagem em publicidade, reprodução indevida de obra intelectual alheia em atividade de fim econômico, e assim por diante.

Carlos Roberto Gonçalves ${ }^{95}$ expõe que o dano moral pode ser conceituado como o prejuízo que atinge o ofendido como pessoa, não lesando o seu patrimônio. É lesão de bem que integra os direitos da personalidade, como a honra, a dignidade, a intimidade, a imagem, o bom nome etc., acarretando à vítima dor, sofrimento, tristeza vexame e humilhação.

Não obstante as diferentes definições apontadas pelos mais renomados doutrinadores, o fato é que o dano moral não corresponde à dor, por si só, mas à repercussão maléfica marcada pelo sofrimento que inunda a alma provocando marcas no ofendido.

\footnotetext{
${ }^{93}$ SANTOS, Antonio Jeová. Dano Moral Indenizável. 2. ed. São Paulo: Lejus, 1999. p. 57.

${ }^{94}$ BITTAR, Carlos Alberto. Revista do Advogado-AASP, n 44. São Paulo: 1994. p. 24.

${ }^{95}$ GONÇALVES, Carlos Roberto, Direito Civil, direito das obrigações. São Paulo: Saraiva, 2002. p. 92.
} 
Pelas elucidações das lições de Ihering ${ }^{96}$, temos que:

Dor física é sinal de perturbação no organismo, é presença de causa que lhe é hostil; adverte-nos do perigo e, pelo sofrimento que nos causa, alerta-nos para a necessidade de sermos previdentes.

Isso sucede exatamente com a dor moral, causada pela ofensa e pela consciente agressão ao nosso direito. De intensidade diversa, analogamente à dor física, conforme a diferença da sensibilidade subjetiva [...], este sofrimento se nos apresenta como dor moral, no homem que ainda não perdeu, de todo, a sensibilidade, ou seja, que não está acostumado aos períodos de ilegalidade ou de ausência de direito.

[...] No primeiro caso, a advertência lembra o dever da autoconservação física, no segundo, o da autoconservação moral.

Quanto à jurisprudência, Roger Stielfemann Leal ${ }^{97}$ adverte que:

O direito ao ressarcimento por dano moral foi, durante as décadas de $40 \mathrm{e}$ 50, objeto de intenso debate. O Código Civil vigente à época (Lei 3.071/1916) não contemplava o instituto de forma expressa, gerando acirrada divergência entre os juristas e operadores do direito. Em reiterados precedentes, o Supremo Tribunal Federal decidiu pela improcedência do direito à indenização, sob o argumento de que não havia base legal que impusesse o dever de reparar danos morais. Em outras palavras, a lesão moral não era bem juridicamente protegido pela legislação brasileira. Descabia ao Poder Judiciário dar aplicação ao que o legislador não determinou.

A corrente majoritária que se articulou no STF naquele período admitia apenas a reparação de danos morais nos casos em que deles decorressem prejuízos materiais. Conforme manifestou-se o Ministro Hahnemann Guimarães, "para que exista dano reparável, é preciso que se verifiquem consequências patrimoniais" 98 . Em outro voto, o respeitável Ministro tornou mais explícita a sua posição a respeito do tema: “Acho indenizável dano moral quando dele decorre prejuízo material. Mas o mero sofrimento moral é um sentimento íntimo, profundo e não me parece indenizável" ${ }^{, 99}$.

\footnotetext{
${ }^{96}$ IHERING. Rudolf Von. A Luta pelo Direito. 5. ed. Tradução José Cretella Jr. e Agnes Cretella. São Paulo: Revista dos Tribunais, 2008. p. 58.

${ }^{97}$ LEAL, Roger Stiefelmann. Memória Jurisprudencial: Ministro Orozimbo Nonato. Brasilia: Supremo Tribunal Federal, 2007. p. 107.

${ }^{98}$ Conforme voto proferido no RE no 11.974/MG, Rel. Min. Hehnemann Guimarães, julgado em 12-5-1953. In: LEAL, Roger Stiefelmann. Memória Jurisprudencial: Ministro Orozimbo Nonato. Brasilia: Supremo Tribunal Federal, 2007. p. 108.

${ }^{99}$ Conforme voto proferido no RE n ${ }^{\text {1 }}$ 11.786/MG, Rel. Min. Hehnemann Guimarães, julgado em 7-11-1950 In: LEAL, Roger Stiefelmann. Memória Jurisprudencial: Ministro Orozimbo Nonato. Brasilia: Supremo Tribunal Federal, 2007. p. 108.
} 
Não obstante o posicionamento da Corte Suprema nas décadas de 1.940 e 1.950, que naquele momento se manifestava contrário ao reconhecimento da indenizabilidade do dano puramente moral, o Ministro Orozimbo Nonato ${ }^{100}$ tornou explícita sua discordância em face de tal posicionamento ${ }^{101}$. Para o Ministro Nonato, "a noção de dano moral é negativa: é o que incide apenas na personalidade moral da vítima, consiste numa dor que não tem qualquer repercussão no patrimônio do lesado" .

Hodiernamente, a obrigação de reparar os danos de natureza moral é matéria pacificada, tanto na doutrina quanto na jurisprudência. A expressa positivação no ordenamento jurídico constitucional colaborou para que a discussão sobre a existência do dever de indenizar pecuniariamente o dano moral fosse superada, senão vejamos:

MORTE EM RAZÃO DE QUEDA DA JANELA DO $3^{\circ}$ ANDAR DE ESCOLA INFANTIL - DANO MORAL AOS PAIS E AVÓS. O sofrimento pela morte de parente é disseminado pelo núcleo familiar, como uma força centrífuga, atingindo cada um dos membros, em gradações diversas, o que deve ser levado em conta pelo magistrado para fins de arbitramento do valor da reparação por dano moral decorrente da morte da neta. A reparação nesses casos decorre do dano individual e particularmente sofrido por cada membro da família ligado imediatamente ao fato (artigo 403 do Código Civil). (REsp 1101213/RJ, Rel. Ministro CASTRO MEIRA, SEGUNDA TURMA, julgado em 02/04/2009, DJe 27/04/2009).

E ainda,

MANDATO FALSO LAVRADO EM TABELIONATO DE NOTAS RESPONSABILIDADE OBJETIVA. CABÍVEL A CONDENAÇÃO DO ESTADO AO PAGAMENTO DE DANOS MORAIS DECORRENTE DE ANULAÇÃO DE COMPRA E VENDA, EFETIVADA COM BASE EM INSTRUMENTO DE MANDATO FALSO, LAVRADO EM TABELIONATO DE NOTAS. Violação, pelo Estado, dos princípios da boa fé e confiança. 3. Possibilidade de valor de fixação do valor da indenização, por esta Corte, "buscando dar solução definitiva ao caso e evitando inconvenientes e retardamento da solução jurisdicional" (Resp 399.028, Rel. Sálvio de Figueiredo, DJ de 15.04.2002), 4. Recurso provido. (REsp. 439465/MS, Rel. Ministro PAULO MEDINA, SEGUNDA TURMA, julgado em 15/10/2002, DJ 09/12/2002. P. 328).

ENCARCERAMENTO EM CONDIÇÕES CAÓTICAS RESPONSABILIDADE OBJETIVA, NÃO CABENDO INVOCAR O PRINCÍPIO DA RESERVA DO POSSÍVEL OU A INSUFICIÊNCIA DE RECURSOS. O dever de ressarcir danos, inclusive morais, efetivamente causados por ato dos agentes estatais ou pela inadequação dos serviços públicos, decorre diretamente do art. $37, \S 6^{\circ}$ da Constituição, dispositivo

\footnotetext{
${ }^{100}$ Apelação Civel no 8.210/DF, Cf. ACi nº 8.210/DF. Rel. Min. Waldemar Falcão, julafada em 18-1-1944. In: LEAL, Roger Stiefelmann. Memória Jurisprudencial: Ministro Orozimbo Nonato. Brasilia: Supremo Tribunal Federal, 2007. p. 109. Nesse julgado, o Ministro Nonato não reconheceu, in casu, a indenização por dano moral porque o autor a requeria com base em prejuízo material, não tendo arguido os fundamentos próprios do dano moral, desvinculados da perda material, para o eminente Ministro não restou provada a ofensa emocional.
} 
autoaplicável, não sujeito à intermediação legislativa ou administrativa para assegurar o correspondente direito subjetivo à indenização. Não cabe invocar, para afastar tal responsabilidade, o princípio da reserva do possível ou a insuficiência de recursos. Ocorrendo o dano e estabelecido o seu nexo causal com a atuação da Administração ou dos seus agentes, nasce a responsabilidade civil do Estado, caso em que os recursos financeiros para a satisfação do dever de indenizar, objeto da condenação, serão providos na forma do art. 100 da Constituição. REsp. 1051023/RJ, Rel. Ministro FRANCISCO FALCÃO, Rel. p/ acórdão Ministro TEORI ALBINO ZAVASCKI, PRIMEIRA TURMA, julgado em 11/11/2008, DJE 01/12/2008).

No âmbito do direito francês, a questão relativa à indenização por danos morais é também bastante debatida. A decisão do Conselho de Estado, precursora do reconhecimento do dever do Estado de indenizar por danos exclusivamente morais, foi proferida em 24 de novembro de 1.961 , no caso conhecido como Letisserand ${ }^{102}$. Paul Letisserand e seu filho de sete anos foram mortalmente vitimados em acidente envolvendo a motocicleta que transitavam e um veículo do Estado.

A viúva pleiteou indenização pelos danos materiais sofridos (reparação da motocicleta, perda do sustento assegurado pelo marido etc.), o pai e avô das vítimas, Camille Letisserand, por seu turno, pleiteou indenização por danos puramente morais sofridos, em virtude da dor da perda dos entes queridos. Embora os tribunais reconhecessem, à época, sobejamente, ser devida a indenização nessas hipóteses, o Conselho de Estado mostrava-se reticente em acolher a tese, sustentando não ser possível mensurar em moeda o tamanho da dor moral sofrida. Ademais, temiam-se os abusos que pudessem advir da mercantilização da dor.

Nesse caso, no entanto, mudando seu entendimento, pela primeira vez o Conselho de Estado francês fixou a indenização do dano puramente moral, reconhecendo que a dor moral, à semelhança da dor física, limita a capacidade de resistência do organismo e diminui a aptidão para o trabalho. Embora a reparação pecuniária não possa substituir o sentimento de afeição, é melhor uma reparação imperfeita do que ausência de reparação.

102 RAMOS, Dora Maria de Oliveira. Responsabilidade do Estado por Dano Moral. Disponível em: <www.egov.ufsc.br/portal/sites/default/files/anexos/6856-6855-1-PB.html> . Acesso em: 06 nov. 2012. 


\subsection{Dano material}

Dano material ou patrimonial é o evento que afeta diretamente o patrimônio (bens, objetos ou propriedades) das pessoas físicas ou jurídicas, e pode ser demonstrado por deterioração total ou parcial que foi gerada por uma ação ou omissão indevida de terceiros, ou ainda, pelo que se deixou de auferir em razão de tal conduta, caracterizando a necessidade de reparação material dos chamados lucros cessantes.

O direito à reparação está expressamente previsto na Constituição Federal e em outros dispositivos legais, como o Código Civil em vigor, o Código de Defesa do Consumidor, além de outras inúmeras normas jurídicas.

Para a reparação do dano material, mostra-se imprescindível demonstrar o nexo de causalidade entre a conduta indevida e o efetivo prejuízo patrimonial que foi suportado. Por sua natureza, evidentemente, a demonstração da extensão do dano material deve ser precisa também quanto ao valor da indenização pretendida, pois o que se visa por meio da ação judicial é a recomposição da situação patrimonial que se tinha antes da ocorrência do dano. Ademais, são considerados danos materiais os que, recaindo sobre coisas móveis ou imóveis, alcançam o patrimônio do prejudicado, tornando-o impróprio para sua destinação, diminuindo sua utilidade econômica, ou, ainda, agravando as condições de sua utilização ${ }^{103}$.

\subsection{Dano pessoal}

Os danos pessoais têm natureza distinta daqueles classificados como materiais, uma vez que atingem a integridade física e o espírito, lesionando o corpo, alterando a estética e causando prejuízos na psique (danos psíquicos que não se enquadrem na hipótese de danos morais), e outras hipóteses, como a prisão indevida ou a manutenção na prisão além do tempo de sentença (art. 5 $, \mathrm{LXXV}, \mathrm{CF} / 88$ ), independentemente do dano moral que desses casos possa ser desencadeado.

Consoante se observa nas lições de Edmir Netto de Araújo ${ }^{104}$ :

\footnotetext{
${ }^{103}$ ARAUJO. Edmir Netto de. Curso de Direito Administrativo. 5. ed. São Paulo: Saraiva, 2010. p. 796.

${ }^{104}$ Idem, Ibidem. p. 796.
} 
A questão que se coloca, quanto aos danos pessoais, é a da valoração para fins de indenização: alguns autores inclinam-se para o arbitramento, judicial ou não, considerando que muitas vezes o dano pessoal se acumula com o dano material e o dano moral, de difícil quantificação.

[...] uma vez que a indenização deve abranger todos os aspectos do prejuízo (perdas, despesas e o que o lesado deixou de auferir), sob o prisma pessoal podem ser considerados danos emergentes (despesas com remédios, tratamentos médicos, intervenções cirúrgicas, tratamento psiquiátrico, despesas judiciais, honorários advocatícios e outras despesas) e lucros cessantes (p.ex. nos casos de invalidez, total ou parcial, diminuição da capacidade laborativa), sendo viável a cumulação da indenização por dano moral pelos mesmos fatos.

\subsection{Dano oriundo de relações de consumo}

Com o advento da Lei 8.078, de 11 de setembro de 1.990, que introduziu o Código de Defesa do Consumidor no ordenamento jurídico pátrio, o Estado tem tornado possível a tutela da parte vulnerável na relação consumerista, reconhecendo expressamente a possibilidade daquele que tenha sido vítima de um acidente de consumo pleitear a reparação junto ao fornecedor responsável pelo menosprezo a qualquer direito, tanto de natureza patrimonial quanto moral.

Os artigos 12 e 14 do CDC consagraram a responsabilidade civil objetiva, pela qual os fabricantes, produtores, fornecedores, construtores, importadores assim como os prestadores de serviços responderão, independentemente da existência de culpa, pela indenização de eventuais danos experimentados pelos consumidores.

Sérgio Cavalieri Filho ${ }^{105}$, elucidando o tema, prescreve que:

[...] o Código de Defesa do Consumidor deu uma guinada de 180 graus na disciplina jurídica então existente, na medida em que transferiu os riscos do consumo do consumidor para o fornecedor. Estabeleceu responsabilidade objetiva para todos os casos de acidente de consumo, quer decorrentes do fato do produto (art. 12), quer do fato do serviço (art. 14). Pode-se dizer que o Código esposou a teoria do risco do empreendimento (ou empresarial), que se contrapõe à teoria do risco de consumo.

Cavalieri Filho salienta, ainda, que, pela teoria do risco do empreendimento, todo aquele que se disponha a exercer alguma atividade no mercado de consumo tem a obrigação

${ }^{105}$ CAVALIERI FILHO, Sérgio. Programa de Responsabilidade Civil. 9. ed. São Paulo: Atlas, 2010. p.484. 
de responder pelos eventuais vícios ou defeitos dos bens e serviços postos à disposição no mercado consumerista, independentemente de culpa. $\mathrm{O}$ consumidor não pode assumir os riscos das relações de consumo, nem tampouco arcar com os prejuízos decorrentes dos acidentes de consumo, ou deixar de ser indenizado.

Exemplo do que acontece na Responsabilidade do Estado, também nas hipóteses de acidente de consumo os riscos devem ser socializados, ou seja, repartidos entre todos, já que os benefícios também são direcionados para todos. É a justiça distributiva que divide os riscos inerentes à sociedade de consumo igualmente, entre todos.

Conforme já dissemos, o artigo 186 do Código Civil de 2.002 manteve a culpa como fundamento na teoria do risco da atividade prevista no parágrafo único dos artigos 927 e 931 do Código Civil Brasileiro de 2.002.

O Código de Defesa do Consumidor, muito embora tenha adotado a teoria da responsabilidade civil objetiva, não optou pela teoria do risco integral, conforme se percebe nos artigos $12, \S 3^{\circ}$ e $14, \S 3^{\circ}$, admitindo, assim, algumas causas de exclusão da Responsabilidade Civil, as quais serão estudadas oportunamente.

Dispõe o artigo 22 do Código de Defesa do Consumidor:

Art. 22 Os órgãos públicos, por si ou suas empresas, concessionárias, permissionárias ou sob qualquer outra forma de empreendimento, são obrigados a fornecer serviços adequados, eficientes, seguros e, quanto aos essenciais, contínuos.

Parágrafo único. Nos casos de descumprimento, total ou parcial, das obrigações referidas neste artigo, serão as pessoas jurídicas compelidas a cumpri-las e a reparar os danos causados, na forma prevista neste código.

Rizzatto Nunes ${ }^{106}$ pondera que o parágrafo único do artigo 22 do CDC traz regra totalmente desnecessária, pois repete o óbvio, ou seja, que os prestadores de serviços públicos são responsáveis pelos vícios dos serviços, bem como pelos danos ocasionados por defeitos. Tal responsabilidade é objetiva, nascendo no texto constitucional, nos termos do $\S 6^{\circ}$, do artigo 37 da $\mathrm{CF} / 88$.

Em nosso entendimento, o legislador fez questão de reforçar o dispositivo constitucional, como forma de garantia, no que se refere ao prestador de serviço público para que não pairassem quaisquer dúvidas sobre o tema, evitando, assim, qualquer argumento em sentido contrário.

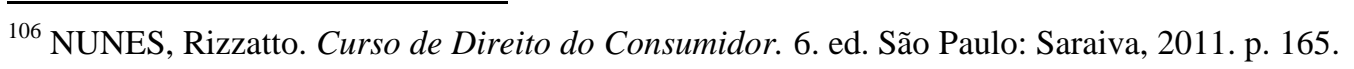


Desta forma, as pessoas jurídicas de direito público estão incluídas no artigo $3^{\circ}$ do $\mathrm{CDC}$, que determina o conceito de fornecedor. Assim, resta sedimentado que todos aqueles que, em nome da pessoa jurídica de Direito Público, direta ou indiretamente, prestem serviços públicos, deverão estar subordinados às regras estabelecidas às relações jurídicas de consumo, excluindo-se apenas os serviços sem remuneração ou custo e os decorrentes de natureza trabalhista.

\subsubsection{Nexo de causalidade}

O nexo causal ou relação de causalidade se configura no fio condutor que liga a causa ao efeito, ou seja, é o liame entre a conduta do agente e o resultado suportado pela vítima. No caso da Responsabilidade do Estado, é o que vincula o fato ou ato administrativo ao dano.

O vocábulo “nexo" significa ligação, vínculo, união, elo. O termo “causalidade” traduz relação de causa e efeito. Dessa forma, nexo de causalidade, ou nexo causal, pode ser entendido como a ligação entre a atividade do Estado e o dano sofrido pelo administrado. Para ser reconhecido o direito à indenização, não basta apenas ocorrer um dano, necessária, também, é a relação de causalidade entre o ato, omissivo ou comissivo do Estado e o dano. ${ }^{107}$

Identificada a presença do nexo de causalidade, resta excluída a necessidade da comprovação de dolo ou culpa, bastando que a vítima demonstre a relação existente entre o dano sofrido e a conduta do agente estatal.

Há diversas teorias da causalidade, sendo mais conhecida a da equivalência das condições; a causalidade imediata e a causalidade adequada ${ }^{108}$.

Yussef Said Cahali ${ }^{109}$ acrescenta a esse rol a Teoria da causalidade eficiente, a Teoria negativa de Mayer e a Teoria da causalidade típica.

A Teoria da equivalência das condições ou dos antecedentes, do alemão Von Buri (1.860), também denominada como conditio sine qua non, é aquela em que, havendo

\footnotetext{
${ }^{107}$ BÜHRING. Márcia Andrea. Responsabilidade Civil Extracontratual do Estado. São Paulo: Thomson-IOB, 2004. p. 120.

${ }^{108}$ Idem, Ibidem. p. 123.

${ }^{109}$ CAHALI, Yussef Said. Responsabilidade Civil do Estado. 3. ed. São Paulo: Revista dos Tribunais, 2007. p. 75.
} 
várias circunstâncias que poderiam ter causado a lesão, qualquer delas poderá ser considerada a causa eficiente.

Segundo Von Buri (1.860), havendo múltiplas causas, todas devem ser consideradas como determinantes da lesão, se não se pode especificar qual delas motivou o dano, implicando diversas responsabilizações:

[...] qualquer fato relacionado com o resultado, ainda que distante, pode ser tomado como causa geradora do prejuízo ou, como se deduz da denominação, as diversas causas se equivalem na análise da origem do dano. Os alemães chamam esta teoria de Bedigungsheoria, na qual todos os elementos que condicionaram o dano são equivalentes ${ }^{110}$.

Esta doutrina sustenta que todas as condições que conduzem a um resultado são a causa desse resultado, sejam mediatas ou imediatas; portanto, basta que o sujeito tenha realizado uma condição desse resultado para que exista relação causal; um fenômeno é condição do outro quando, suprimindo-o mentalmente, faz-se impossível admitir que o fato consequente teria produzido tal como ocorreu (condição sine qua non) ${ }^{111}$.

A Teoria da causalidade imediata é aquela que determina que, entre o fato e o dano, deve haver uma relação de causa e efeito direta e imediata. Essa teoria, identificada também como teoria da causa próxima, estudada pelas escolas de Mosca, Coviello, Fórmica, Dumoulin, Pothier entre outras, sustentou que há nexo causal entre o dano e a causa quando esta é direta, imediata, daí derivando prejuízo. Portanto, considera-se causa do dano o fato de que deriva mais proximamente ${ }^{112}$.

A Teoria da casualidade imediata, chamada por Von Buri de Teoria da causa próxima ou da causa direta, procura selecionar, entre todas as condições de um resultado, uma de particular relevância, a que considera a causa; a teoria da causa próxima, pelo menos em sua formulação inicial, escolhe como causa a condição cronologicamente mais próxima do evento que se quer imputar ${ }^{113}$.

Na Teoria da causalidade adequada, a causa deve ser apta a produzir o resultado danoso, ou seja, o resultado deve se adequar à causa. $\mathrm{O}$ francês Gabriel Marty, baseado na doutrina de Von Bar, em 1.881, e Von Kries, em 1.888, desenvolveu a teoria da causalidade

\footnotetext{
${ }^{110}$ CAHALI, Yussef Said. Responsabilidade Civil do Estado. 3. ed. São Paulo: Revista dos Tribunais, 2007. p. 123.

${ }^{111}$ Idem, Ibidem. p. 75.

${ }^{112}$ BÜHRING. Márcia Andrea. Responsabilidade Civil Extracontratual do Estado. São Paulo: Thomson-IOB, 2004. p. 124.

${ }^{113}$ CAHALI, Yussef Said. Op. cit.. p. 75.
} 
adequada, pela qual devem ser excluídas como causas aquelas condutas que, se inexistentes, não impediriam o surgimento do prejuízo, em oposição à teoria da equivalência das causas. Ou seja, é causa do dano o fato que tenha como efeito inevitável a lesão ${ }^{114}$.

Yussef Said Cahali ${ }^{115}$ assevera, acerca da Teoria da causalidade adequada, assentando, assim, a sua discrepância fundamental com a doutrina da equivalência, que não basta que um fato seja condição de um resultado para que o agente se possa considerar autor desse evento, sempre que as condições não sejam equivalentes.

Seguindo os passos do mesmo doutrinador, citando a Teoria da causalidade eficiente, explica que, de acordo com essa doutrina, as condições que conduzem a um resultado não são equivalentes, e existe sempre um antecedente que, em virtude de um intrínseco poder qualitativa ou quantitativamente apreciado, é a verdadeira causa do evento; causa seria, pois, para essa teoria, a que tem um intrínseco poder de produção do fenômeno.

No que tange à Teoria negativa de Meyer, tem-se que M.E. Meyer aceita os postulados da equivalência das condições para chegar a uma posição negativa do problema da causalidade porque entende que, sendo toda condição sine qua non relevante, carece de importância na prática comprovar a existência de uma relação de causalidade para o efeito de imputação das consequências; o que resultaria decisivo sob tal aspecto seria a indagação da culpabilidade.

Por derradeiro, Cahali aponta a Teoria da causalidade típica, anunciada por Beling, a qual, de certa forma, é uma ideia que conduz também à negação do problema da causalidade, pelo menos dentro do âmbito do direito penal, substituindo-a pela subordinação da ação a um tipo.

No ordenamento jurídico brasileiro, a responsabilidade civil é orientada pelo princípio da causalidade adequada, também chamado de princípio do dano direto e imediato, significando dizer que ninguém pode ser responsabilizado por aquilo a que não tiver dado causa. Assim, apenas e tão somente, dá ensejo à responsabilidade civil, o nexo de causalidade direto e imediato, ou seja, quando houver uma ligação lógica direta entre a conduta e o prejuízo efetivado.

\footnotetext{
114 BÜHRING. Márcia Andrea. Responsabilidade Civil Extracontratual do Estado. São Paulo: Thomson-IOB, 2004.. p. 125 .

${ }^{115}$ CAHALI, Yussef Said. Responsabilidade Civil do Estado. 3. ed. São Paulo: Revista dos Tribunais, 2007.p. 75.
} 


\subsubsection{Culpa - aspectos gerais}

Definir o conceito de culpa, ou o que os franceses chamam de faute, é tarefa extremamente árdua, pelo uso contumaz do vocábulo, ora em sentido subjetivo de "reprimenda" ou "censura moral" que se faz ao agente, ora na acepção objetiva de "infração" a determinada estrutura ${ }^{116}$.

No nosso sistema jurídico prevalece a regra geral de que o dever de indenizar resulta da prática de atos ilícitos e que decorre da culpa, ou seja, da reprovabilidade ou censurabilidade da conduta do agente. O comportamento do agente será reprovado ou censurado quando, diante de situações concretas, se admite que ele poderia ou deveria ter agido de modo diferente. Portanto o ato ilícito qualifica-se pela culpa. Não havendo culpa, não haverá, em regra, qualquer responsabilidade.

Antes de tecer as considerações mais importantes sobre o assunto, é importante lembrar que, vivendo em sociedade, tem-se que pautar a conduta de modo a não causar dano a ninguém, viver honestamente e dar a cada um aquilo que lhe pertence. Ao praticar os atos da vida, mesmo que lícitos, deve-se observar a cautela necessária para que de seu atuar não resulte lesão a bens jurídicos alheios. Essa cautela chama-se dever de cuidado. A inobservância do dever de cuidado torna a conduta culposa, o que evidencia que, na culpa, importa não o fim do agente, que normalmente é lícito, mas o modo e a forma imprópria de atuar.

René Savatier ${ }^{117}$ ensina que:

[...] culpa (faute) é a inexecução de um dever que o agente podia conhecer e observar. Se efetivamente o conhecia e deliberadamente o violou, ocorre o delito civil ou, em matéria de contrato, o dolo contratual. Se a violação do dever, podendo ser conhecida e evitada, é involuntária, constitui a culpa simples, chamada, fora da matéria contratual, de quase-delito.

Continua o autor, argumentando que a culpa comporta dois elementos: um, mais caracterizadamente objetivo, o dever violado; outro, preferentemente subjetivo, a imputabilidade ao agente. Analisando a definição apresentada, constata-se que o autor considera impossível definir a culpa sem partir da noção do dever.

\footnotetext{
${ }^{116}$ CRETELLA JR., José. O Estado e a obrigação de indenizar. Rio de Janeiro: Forense. 2002. p. 67.

${ }^{117}$ SAVATIER, René. Traité de la responsabilité civile em droit français. Paris: R. Picho net R. durand Auzias, 1951, t. 1, apud DIAS, José Aguiar. Da Responsabilidade Civil. 12. ed. Rio de Janeiro: Lumen Juris, 2011. p. 112.
} 
A prova da culpa, em muitos casos, é verdadeiramente diabólica, erigindo-se barreira intransponível para o lesado. Em tais casos, os tribunais têm examinado a prova da culpa com tolerância, extraindo-a, muitas vezes, das próprias circunstâncias em que se dá o evento.

No caso da culpa presumida, a vítima só precisa provar o dano e o nexo causal entre este e a conduta do agente. Inverte-se o ônus da prova quanto à culpa. Neste caso, terá o ofensor que provar que não agiu com culpa para livrar-se da responsabilização, como, por exemplo, na hipótese do art. 1527 do Código Civil vigente:

\footnotetext{
Art. 1.527. O dono, ou detentor, do animal ressarcirá o dano por este causado, se não provar:

I - que o guardava e vigiava com cuidado preciso;

II - que o animal foi provocado por outro;

III - que houve imprudência do ofendido;

IV - que o fato resultou de caso fortuito, ou força maior.
}

Fala-se em culpa contra a legalidade quando o dever violado resulta de texto expresso de lei ou regulamento, como ocorre, por exemplo, com o dever de obediência a certas regras técnicas no desempenho de profissões ou atividades regulamentadas. A mera infração da norma regulamentar é fator determinante da responsabilidade civil - cria em desfavor do agente uma presunção de ter agido culpavelmente, incumbindo-lhe o difícil ônus da prova em contrário.

No que tange à culpa concorrente, atualmente denominada de concorrência de causas ou de responsabilidade, tem-se que ela ocorre quando, paralelamente à conduta do agente causador do dano, há também conduta culposa da vítima, de modo que o evento danoso decorre do comportamento culposo de ambos, isto é, a vítima também concorre para o evento, e não apenas aquele que é apontado como único causador do dano. Conclui-se que, na culpa concorrente, as duas condutas - do agente e da vítima - concorrem para o resultado em grau de importância e intensidade, de sorte que o agente não produziria o resultado sozinho, contando, para tanto, com o efetivo auxílio da vítima. Havendo culpa concorrente, a doutrina e a jurisprudência recomendam dividir a indenização, não necessariamente pela metade, mas proporcionalmente ao grau de culpabilidade de cada um dos envolvidos, que deve ser observado objetivamente, isto é, segundo o grau de causalidade do ato de cada um.

Importante esclarecer que nem sempre o ato culposo da vítima importará culpa concorrente, pois em matéria de responsabilidade civil, adota-se a teoria da causa adequada e não da equivalência dos antecedentes, que só tem aplicação no Direito Penal. Ocorre que, se embora culposo, o fato de determinado agente era inócuo para a produção do dano, não pode 
ele, por certo, arcar com prejuízo algum. O que se deve indagar é, pois, qual dos fatos ou das culpas foi decisivo para o evento danoso, ou seja, qual dos atos imprudentes fez com que o outro, que não teria consequências de si só, determinasse, completado por ele, o acidente. Então, a culpa grave necessária e suficiente para o dano exclui a concorrência de culpas - a responsabilidade é de quem interveio com culpa suficiente para o dano. A concorrência de culpas, portanto, por se tratar de concorrência de causas, só deve ser admitida em casos excepcionais, quando não se cogita de preponderância causal manifesta e provada da conduta do agente.

Quanto ao nível de gravidade, a culpa será classificada como "grave" se o agente atuar com grosseira falta de cautela, com descuido injustificável ao homem normal, impróprio ao comum dos homens. É a culpa com previsão do resultado, também chamada de "culpa consciente", que se avizinha do dolo eventual do Direito Penal. Em ambos há previsão ou representação do resultado, só que, no dolo eventual, o agente assume o risco de produzi-lo, enquanto na culpa consciente ele acredita sinceramente que o evento não ocorrerá. Pode-se citar, como exemplo, a situação do motorista que, em excesso de velocidade, atravessa um sinal de trânsito fechado. Haverá culpa leve se a falta puder ser evitada com atenção ordinária, com o cuidado próprio do homem comum, de um bonus pater familias. Já a culpa levíssima caracteriza-se pela falta de atenção extraordinária, pela ausência de habilidade especial ou conhecimento singular.

Cumpre dizer que, ainda que levíssima, a culpa obriga a indenizar - in lege aquilea et levíssima culpa venit - medindo-se a indenização não pela gravidade da culpa, mas pela extensão do dano. Cabe dizer que o novo Código Civil abriga essa ideia no seu art. 944.

Art. 944. A indenização mede-se pela extensão do dano.

Parágrafo único. Se houver excessiva desproporção entre a gravidade da culpa e o dano, poderá o juiz reduzir, equitativamente, a indenização.

Quanto ao conteúdo da conduta culposa pode ser classificada em: culpa in eligendo, in vigilando, in custodiendo e in committendo e in omittendo. Quando o fato é praticado por terceiro, denomina-se culpa in eligendo aquela que se caracteriza pela má escolha do preposto. A culpa do patrão ou comitente é presumida pelo ato culposo do empregado ou preposto, consoante a Súmula 341 do STF, em razão da má escolha daquele.

E, ainda, de acordo com os termos do art. 933 do Novo Código Civil de 2.002, se admitir ou manter a seu serviço empregado não habilitado legalmente ou sem aptidões requeridas, não há mais que se indagar se houve ou não culpa in eligendo, respondendo, por 
isso, independentemente daquela culpa, pelos fatos lesivos por ele praticados. Por via de consequência, sua responsabilidade será objetiva.

Para José Maria Pinheiro Madeira ${ }^{118}$, culpa in eligendo ocorre:

Quando um indivíduo, na prática de seus atos, os faz em nome de outro, e em consequência destes, causa um resultado danoso a alguém, aquele que se fez representar deve responder pelos atos de seu representante, suportando a reparação dos referidos danos, pois caracterizada está - nesta hipótese - a culpa in eligendo, dada a escolha inadequada feita de seu representante ou preposto. Daí a acuidade que se sucinta quando da escolha de alguém para representá-lo, pois agindo este com dolo ou culpa, se causar dano a terceiros, responsável será pelo prejuízo aquele que o elegeu para tal função. Esta culpa nasce quando da escolha de seu representante ou preposto.

A culpa in vigilando, por sua vez, decorre da falta de atenção ou cuidado com o procedimento de outrem que está sob a guarda ou responsabilidade do agente como, por exemplo, os pais que respondem pelos atos dos filhos menores. Aqui, com as inovações do Novo Código Civil, da mesma forma, a responsabilidade será objetiva, nos termos do já citado art. 933.

A culpa in custodiendo é a decorrente da falta de atenção em relação a animal ou coisa que estavam sob os cuidados do agente. Em consonância com os arts. 936 e 937 da Lei civil em vigor, tem-se que, em certos casos, com o escopo de facilitar a prova do ilícito, estabelecem-se presunções iuris tantum de culpa, isto é, que admitem prova em contrário. $\mathrm{O}$ lesado exonerar-se-á do ônus da prova, que se transferirá ao lesante.

Por derradeiro, se o agente praticar um ato positivo (imprudência), sua culpa é in committendo ou in faciendo; se cometer uma abstenção (negligência) tem-se culpa in omittendo, por exemplo, enfermeira que, por estar distraída, não observa que o aparelho de respiração artificial não está funcionando corretamente e o paciente fica sem oxigênio, deixando-o morrer. Observe-se que a omissão só poderá ser considerada causa jurídica do dano se houver existência do dever de praticar o ato não cumprido e certeza ou grande probabilidade de o fato omitido ter impedido a produção do evento danoso.

\footnotetext{
${ }^{118}$ MADEIRA, José Maria Pinheiro. Administração Pública. TOMO II. 11.ed. Rio de Janeiro: Elsevier, 2010. p. 266.
} 


\subsection{FUNDAMENTOS DA RESPONSABILIZAÇÃO DO ESTADO}

Quando o Estado, atuando regularmente no desempenho de suas atribuições, causa danos, a obrigação de indenizar está fundamentada no princípio da legalidade e, com a indenização restaura-se a legalidade alvejada. Por outro lado, quando o fundamento é um ato ilícito, a reparação está fundada no princípio da igualdade, e a indenização restaura a isonomia violada.

A Responsabilidade do Estado pode ocorrer em qualquer lugar e em qualquer momento, desde que haja a ocorrência de um resultado danoso, originado por fato, ato, operação ou comportamento de pessoas ligadas, direta ou indiretamente, à execução do serviço público, oriundo de ato lícito ou ilícito.

A legitimidade para exigir a reparação oriunda de prejuízos eventualmente suportados, em regra, é apenas do lesado e seus herdeiros, entretanto é bem possível que também as pessoas que vivam sob a dependência econômica da vítima possam pleitear eventual indenização, ainda que não sejam seus sucessores, bastando apenas comprovação de que foram prejudicados, mesmo que indiretamente.

A ofensa pode ir além da esfera do próprio ofendido, ocorrendo o dano direto, indireto, ou ricochete. Embora, o dano direto almeje pessoalmente o caráter da vítima, no reflexo, não considera diretamente o ilícito perpetrado, mas sua decorrência. Pois uma lesão direta a uma pessoa pode ricochetear contra outra, de tal sorte que se sinta ofendida tal qual a própria vítima.

Em relação ao sofrimento experimentado por família que tenha um de seus membros ceifado de seu convívio em virtude de uma tragédia, há de se questionar quem seria parte legítima para perseguir a reparação, a mãe, o pai, o irmão, o filho, o cônjuge etc. Qualquer um é pertinente para avocar a legitimidade para si, atuando em nome próprio de algo que diretamente não lhe foi concretizado. O sentimento de dor acondicionado pela mãe é de igual sorte experimentado pelo pai, assim como os demais familiares por reflexo. É o entendimento das Cortes brasileiras, in verbis:

PROCESSO CIVIL - AGRAVO DE INSTRUMENTO - NEGATIVA DE PROVIMENTO AGRAVO REGIMENTAL - RESPONSABILIDADE CIVIL-INDENIZAÇÃO-DANO MORAL - MORTE DE IRMÃ - VALOR DA INDENIZAÇÃO-RAZOABILIDADE - DESPROVIMENTO.

1 - Os irmãos têm direito à reparação do dano moral sofrido com a morte de outro irmão, haja vista que o falecimento da vítima provoca 
dores, sofrimentos e traumas aos familiares próximos, sendo irrelevante qualquer relação de dependência econômica entre eles. Precedentes.

2 - Como cediço, o valor da indenização sujeita-se ao controle do Superior Tribunal de Justiça, sendo certo que, na sua fixação, recomendável que o arbitramento seja feito com moderação, proporcionalmente ao grau de culpa, ao nível socioeconômico dos autores e, ainda, ao porte econômico dos réus, orientando-se o juiz pelos critérios sugeridos pela doutrina e pela jurisprudência, com razoabilidade, valendo-se de sua experiência e do bom senso, atento à realidade da vida e às peculiaridades de cada caso. In casu, o valor fixado pelo Tribunal a quo, a título de reparação de danos morais, mostra-se razoável, limitando-se à compensação do sofrimento advindo do evento danoso. 3 - Agravo regimental desprovido. (AgR-ED-AG n. 678.435/RJ, Rel. Min. Jorge Scartezzini, DJU de 11.09.2006, p. 289).

Yussef Said Cahali apregoa que a responsabilidade civil do Estado se configura na “obrigação legal que lhe é imposta de ressarcir os danos causados por suas atividades a terceiros"119 . A responsabilidade do Estado possui como estrutura básica o dever legal imposto a este de reparar danos causados a terceiros seja pela ação ou omissão de seus agentes.

Sem dúvidas, a instituição da responsabilidade objetiva como mecanismo para melhorar o acesso à justiça representa enorme contribuição para a efetividade da prestação jurisdicional, o que torna a justiça mais acessível, principalmente aos menos favorecidos, contribuindo para o Estado de Direito.

José Acir Lessa Giordani ${ }^{120}$ ressalta a importância da responsabilidade objetiva como instrumento de equilíbrio social, na medida em que funciona como agente facilitador do acesso à justiça, mormente por aqueles em situação de vulnerabilidade social, utilizando como exemplo a Lei 8.078/90 (Código de Defesa do Consumidor), na qual sedimentou-se a hipossuficiência e a vulnerabilidade do consumidor, em face da superioridade econômica, técnica e estrutural de que dispõe o fornecedor de produtos ou serviços. Para alcançar o reequilíbrio da relação consumerista, é necessário conceder ao consumidor uma série de prerrogativas, tais como a inversão do ônus da prova, a interpretação dos contratos de forma mais favorável ao consumidor, a flexibilização do princípio da relativização do contrato, e a responsabilidade objetiva, por óbvio, está inserida entre tais prerrogativas.

\footnotetext{
${ }^{119}$ CAHALI, Yussef Said. Responsabilidade Civil do Estado,3. ed. São Paulo: Revista dos Tribunais, 2007. p. 14.

${ }^{120}$ GIORDANI, José Acir Lessa. A Responsabilidade Civil objetiva Genérica no Código Civil de 2002. 2. ed. Rio de Janeiro: Lumen Juris, 2007. p. 68.
} 
A referida lei criou, nos mesmos moldes do Direito do Trabalho, um desequilíbrio jurídico em favor do consumidor para compensar o desequilíbrio econômico, técnico e estrutural existente em favor do fornecedor.

A responsabilidade objetiva dispensa a prova de culpa, facilitando o acesso à justiça por parte da vítima, que está desobrigada de provar a culpa do ofensor e alcança a indenização de forma muito mais rápida e fácil, bastando provar o dano efetivamente sofrido.

\subsection{CAUSAS EXCLUDENTES E ATENUANTES DA RESPONSABILIDADE ESTATAL}

O nexo de causalidade é o elemento principal da responsabilidade do Estado, mas pode desaparecer se a causa do dano não estiver ligada ao serviço público; nessas hipóteses as excludentes têm o condão de afastar o nexo de causalidade, desobrigando, assim, a reparação. São destacadas como causas excludentes da responsabilidade: a força maior, o caso fortuito, a culpa da vítima e a culpa de terceiros.

Edmir Netto de Araújo ${ }^{121}$ acrescenta ao rol supracitado o estado de necessidade, muito embora reconheça que não se trate de excludente pacificamente admitida.

Celso Antônio Bandeira de Mello ${ }^{122}$, por seu turno, afirma que

Nos casos de responsabilidade objetiva, o Estado só se exime de responder se faltar o nexo entre seu comportamento comissivo e o dano. Isto é: eximese apenas se não produziu a lesão que lhe é imputada ou se a situação de risco inculcada a ele inexistiu ou foi sem relevo decisivo para a eclosão do dano. Fora daí responderá sempre.

Maria Sylvia Zanella Di Pietro ${ }^{123}$ não considera o caso fortuito causa excludente, pois entende que tal hipótese se dá em decorrência de ato humano ou de falha na administração. No caso de força maior, a responsabilização do Estado pode ocorrer se aliada à força maior houver a omissão do Estado na realização de um serviço público.

\footnotetext{
121 ARAUJO. Edmir Netto de. Curso de Direito Administrativo. 5. ed. São Paulo: Saraiva, 2010. p. 782.

122 BANDEIRA DE MELlo, Celso Antônio. Curso de Direito Administrativo. 28. ed. São Paulo: Malheiros, 2011. p. 1032.

${ }^{123}$ DI PIETRO, Maria Silvia Zanella, Direito Administrativo. 24. ed. São Paulo: Atlas, 2011. p. 652.
} 
Para Diógenes Gasparini ${ }^{124}$, a responsabilização do Estado é excluída em duas hipóteses: a primeira diz respeito ao acontecimento imprevisível e irresistível causado por força externa ao Estado (caso fortuito e/ou força maior); demonstrada a imprevisibilidade ou a irresistibilidade, nada mais é necessário para liberar a Administração Pública da obrigação de reparar o dano; a segunda hipótese é aquela relativa à situação em que a vítima deu causa ao evento danoso.

Importante destacar que cabe ao Estado produzir provas da existência das mencionadas causas excludentes de sua responsabilidade; não se desincumbindo do ônus probandi, será responsabilizado objetivamente, nos termos da Carta Magna. É, também, por esse caminho que a jurisprudência brasileira vem enveredando.

APELAÇÃO CÍVEL. RESPONSABILIDADE CIVIL EM ACIDENTE DE TRÂNSITO. ATROPELAMENTO EM FERROVIA. CULPA EXCLUSIVA DA VÍTIMA. 1. A responsabilidade da empresa concessionária de transporte ferroviário de cargas é objetiva em relação a terceiros usuários ou não usuários do serviço de transporte, prescindindo da prova da culpa pelo evento ocorrido, segundo decorre do art. $37, \S 6^{\circ}$, da Constituição Federal. Entendimento extraído do julgamento do Recurso Extraordinário $\mathrm{n}^{\circ} 591.874$, pelo Plenário do STF. Responsabilidade esta que somente pode ser afastada na hipótese de culpa exclusiva da vítima, caso fortuito, força maior ou fato de terceiro. 2. Conjunto probatório contido nos autos que impõe a confirmação da excludente de responsabilidade reconhecida na sentença, pois deixa evidente que a autora Natália, em estado de embriaguez, mesmo ciente da passagem de trens no local, deitou-se sobre os trilhos da via férrea, sendo a exclusiva responsável pelo infortúnio do qual foi vítima. APELAÇÃO IMPROVIDA. (Apelação Cível No 70047091590, Décima Primeira Câmara Cível, Tribunal de Justiça do RS, Relator: Luiz Roberto Imperatore de Assis Brasil, Julgado em 08/08/2012).

Por derradeiro, cumpre destacar que a admissão de excludentes de responsabilização é decorrente de um princípio lógico de que ninguém poderá ser penalizado por atos que não cometeu ou para os quais não concorreu.

\subsubsection{A força maior}

A força maior exonera a responsabilidade estatal, uma vez que seu fundamento está baseado na impossibilidade de resistir a uma causa conhecida, normalmente, um fato da natureza (chuvas torrenciais, tempestades, maremotos etc.). A força externa projeta-se com

${ }^{124}$ GASPARINI, Diógenes. Direito Administrativo. 10. ed. São Paulo: Saraiva. p. 902-903. 
tanta intensidade, e o Estado queda-se impotente diante da ausência de previsibilidade do evento, obrigando-se à subjugação.

A precisa definição de José Cretella Júnior ${ }^{125}$ tem evidência solar:

Fenômenos da natureza (cataclismas, terremotos, ciclones, furacões, inundações, erupções vulcânicas, maremotos, trombas d’água), entre outros fatos que, comprovados, se apresentam com o traço de inevitabilidade mesmo diante das possibilidades técnicas de nossos dias, impotentes para evitar-lhes os efeitos, configuram a força maior, evento imprevisível e alheio à vontade do sujeito a quem se pretende atribuir a responsabilidade pelo prejuízo causado.

Para Maria Sylvia Zanella Di Pietro ${ }^{126}$, trata-se de acontecimento imprevisível, inevitável e estranho à vontade das partes - como, por exemplo, uma tempestade, um terremoto, um raio. No seu entendimento, não pode ser imputável à Administração e não pode haver incidência de responsabilidade, pois não há nexo de causalidade entre o dano e o comportamento da Administração.

Nesse mesmo sentido, José Carlos de Oliveira ${ }^{127}$, fazendo referência aos eventos naturais e sua inevitabilidade, destaca que as chuvas torrenciais, os raios, os vendavais etc. constituem força maior. Entretanto, as enchentes nas ruas, assim como desabamentos de encostas ou deslizamento de terras em certas épocas do ano não podem ser categorizados como eventos de força maior, pois sua materialização advém da incúria do Poder Público.

No caso das enchentes, para que o prejudicado afaste a excludente da responsabilidade fundada em força maior e veja efetivada a responsabilização do Estado, é necessário demonstrar que, além da previsibilidade do evento natural e a contumácia de sua ocorrência, outros fatores agravaram o resultado danoso e prejudicial. Isto é, a ausência de manutenção nos equipamentos destinados a facilitar a vazão das águas, e a inoperância desses serviços a cargo da Administração.

\footnotetext{
${ }^{125}$ CRETELLA JR. José. O Estado e a Obrigação de Indenizar. 2. ed. Rio de Janeiro: Forense, 2002. p. 134-135.

${ }^{126}$ DI PIETRO, Maria Silvia Zanella. Direito Administrativo. 24. ed. São Paulo: Atlas, 2011. p. 652.

${ }^{127}$ OLIVEIRA, José Carlos de. Responsabilidade Patrimonial do Estado, Danos decorrentes de enchentes, vendavais e deslizamentos. São Paulo: Edipro, 1995. p. 43.
} 


\subsubsection{O caso fortuito}

Diferentemente da força maior, no caso fortuito, a causa do evento permanece desconhecida e, em princípio, não desobriga o Estado de responsabilização, em decorrência do risco assumido pelo desempenho das atividades públicas. Ou seja, é indiferente para aferição da responsabilidade objetiva do Poder Público, quando demonstrado o mau funcionamento do serviço público.

Alexandre de Moraes ${ }^{128}$ conceitua o caso fortuito como hipótese que ocorrerá quando o dano for causado, exclusivamente, por conduta dolosa ou culposa de terceiros, e independente da vontade das partes, exemplificando seu entendimento com o seguinte julgado:

CASO FORTUITO E EXCLUSÃO DA RESPONSABILIDADE CIVIL DO ESTADO: TJRJ: RESPONSABILIDADE CIVIL - VÍTIMA FATAL DE BALA PERDIDA, ATINGIDA ENQUANTO ASSISTIA A UM JOGO DE FUTEBOL EM ESTÁDIO PÚBLICO. O art. $37, \S 6^{\circ}$, da Constituição Federal, somente envolve responsabilidade objetiva da Administração pelos danos causados a terceiros por seus agentes, nessa qualidade. Adoção da teoria do risco administrativo. Decorrendo o dano de ato precatório de terceiro, a responsabilidade do ente público só ocorrerá se comprovada a sua culpa subjetiva. Inexistindo prova de omissão específica ou atuação deficiente, não há como acolher-se o pretendido ressarcimento (TJRJ $-1^{\text {a }}$ Câmara Civil - AC no 3257-00/RJ - Rel. Des. Amaury de Souza, decisão 158-2000. Ementário AASP, nº 2207, pg. 376).

Já Maria Sylvia Zanella Di Pietro ${ }^{129}$ acredita que a hipótese de caso fortuito não pode ser destacada como causa excludente de responsabilidade do Estado, porque este pode ser identificado nas hipóteses em que o dano seja resultante de ato humano ou de falha da Administração, apontando como exemplo a situação em que há o rompimento de uma adutora ou de um cabo elétrico, causando danos a terceiros.

Vale destacar que as noções de força maior e caso fortuito não são pacíficas na doutrina, e apesar de semelhantes, não se confundem.

O Código Civil Brasileiro atual, instituído pela Lei 10.406, de 10 de janeiro de 2002, no artigo 393, estabelece que "O devedor não responde pelos prejuízos resultantes de caso fortuito ou força maior, se expressamente não se houver por eles responsabilizado".

\footnotetext{
${ }^{128}$ MORAES, Alexandre. Constituição do Brasil Interpretada e Legislação Constitucional. São Paulo: Atlas, 2007. p. 903.

${ }^{129}$ DI PIETRO, Maria Silvia Zanella. Direito Administrativo. 24. ed. São Paulo: Atlas, 2011. p. 652.
} 
Completando, no parágrafo único, "O caso fortuito ou de força maior verifica-se no fato necessário, cujos efeitos não era possível evitar ou impedir” .

O referido dispositivo replicou o artigo 1.508 do Código Civil de 1.916, e em virtude da imprecisão do texto legal que não os diferencia, estes dois institutos são objeto de divergência doutrinária, tanto no que diz respeito à sua aplicação ao caso concreto quanto às respectivas definições.

\subsubsection{Estado de necessidade}

O estado de necessidade é a circunstância em que o Poder Público, vislumbrando um bem maior a ser tutelado, causa um dano a terceiros. Tais circunstâncias podem ser exemplificadas em situações de guerra ou convulsões sociais, em que são experimentados prejuízos a indivíduos em prol da proteção à Sociedade.

No entendimento de Marcia Andrea Bühring ${ }^{130}$, estão inseridas no estado de necessidade aquelas situações em que, mesmo se o dano houver sido causado pela ação do Estado, este o faz com o intuito de proteger um interesse maior da coletividade, o que torna a prática do evento que desencadeou o dano plenamente justificável.

O estado de necessidade evidencia-se diante de circunstâncias de perigo iminente não provocadas pelo agente público, e quando se faz necessário um sacrifício de interesse particular, em favor do Poder Público, titular de um interesse coletivo, autorizando-o a intervir na esfera privada, a fim de defender e preservar tal interesse.

Dessa forma, conclui-se que o Poder Público, dotado de discricionariedade para defender o interesse público e intervir na esfera particular, diante de fatos excepcionais, estará isento de reparar os danos sofridos pelos administrados em decorrência de sua atuação nesse sentido.

${ }^{130}$ BÜHRING. Márcia Andrea. Responsabilidade Civil Extracontratual do Estado. São Paulo: Thomson-IOB, 2004. p. 166-167. 


\subsubsection{A culpa da vítima}

A culpa da vítima pode ser exclusiva ou concorrente. A culpa é exclusiva, quando, a vítima sozinha, contribui para a ocorrência do evento danoso. Exemplo típico de culpa exclusiva da vítima é aquele citado pelo Prof. José Maria Pinheiro Madeira ${ }^{131}$, nos casos dos "surfistas ferroviários", que são os passageiros que de forma irresponsável e antissocial escalam os vagões ferroviários, e viajam acomodados no teto.

Celso Antonio Bandeira de Mello ensina que a culpa do lesado não é, em si mesma, causa excludente, pois na sua percepção, sendo a suposta vítima causadora do dano, desaparece o nexo causal. A culpa do lesado não é importante, mas o será na medida em que, por meio dela, seja comprovada a ausência de comportamento estatal produtor da lesão ${ }^{132}$.

Maria Sylvia Zanella Di Pietro pondera que ${ }^{133}$ :

Quando houver culpa da vítima, há que se distinguir se é sua culpa exclusiva ou concorrente com a do poder público; no primeiro caso, o Estado não responde; no segundo caso, atenua-se a sua responsabilidade, que se reparte com a da vítima. Essa solução, que já era defendida e aplicada pela jurisprudência, está hoje consagrada no Código Civil.

De fato, o artigo 945 do Código Civil vigente determina que "Se a vítima tiver concorrido culposamente para o evento danoso, a sua indenização será fixada tendo-se em conta a gravidade de sua culpa em confronto com a do autor do dano".

No mesmo sentido, Alexandre de Moraes ${ }^{134}$ entende que:

[...] havendo culpa exclusiva da vítima, ficará excluída a responsabilidade do Estado. Entretanto, se a culpa for concorrente, a responsabilidade civil do Estado deverá ser mitigada, repartindo-se o quantum da indenização. Nesse sentido, Jean Rivero afirma que, "se o próprio lesado tornou o dano inevitável, ou o agravou, a responsabilidade da Administração fica total ou parcialmente excluída" ${ }^{\prime 35}$.

\footnotetext{
${ }^{131}$ MADEIRA. José Maria Pinheiro. Administração Pública.TOMO II. 11. ed. Rio de Janeiro: Elsevier, 2010. p. 275.

${ }^{132}$ BANDEIRA DE MELlO, Celso Antônio. Curso de Direito Administrativo. 28. ed. São Paulo: Malheiros, 2011. p. 1032.

${ }^{133}$ DI PIETRO, Maria Sylvia Zanella. Direito Administrativo. 24. ed. São Paulo: Atlas, 2011. p. 652.

${ }^{134}$ MORAES, Alexandre. Constituição do Brasil Interpretada. 7. ed. São Paulo: Atlas, p. 896.

${ }^{135}$ RIVERO, Jean. Direito Administrativo. Coimbra: Almedina, 1981 apud MORAES, Alexandre. Constituição do Brasil Interpretada. 7. ed. São Paulo: Atlas, p. 896.
} 


\subsubsection{A culpa de terceiros}

Na culpa de terceiros, também chamada de fato de terceiros, não há que se falar em responsabilização estatal, pois a conduta culposa é do terceiro totalmente estranho ao organismo estatal.

A equação dos dados dirigidos à causalidade responsabilizante não chega a se formar, pois não ocorre - no caso de culpa devidamente comprovada de terceiro - quer a ação danosa, quer a omissão prejudicial do Estado, mas, sim, de um terceiro, alienígena, naquele exato momento, à relação Estado-administrado ${ }^{136}$.

Maria Sylvia Zanella Di Pietro adverte que, quando se trata de ato de terceiros, como é o caso de danos causados por multidão ou por delinquentes, o Estado responderá se ficar caracterizada a sua omissão, a sua inércia, a falha na prestação do serviço público. A culpa do serviço público, demonstrada pelo seu mau funcionamento, não-funcionamento ou funcionamento tardio, é suficiente para justificar a responsabilidade do Estado ${ }^{137}$.

\section{Conclusão}

Neste primeiro capítulo, buscou-se delinear, em apertada síntese, um panorama geral da trajetória histórica da responsabilidade do Estado ao longo dos tempos. Verificamos que, muito embora alguns respeitáveis doutrinadores utilizem a terminologia Responsabilidade Civil do Estado, parece mais coerente a utilização da denominação Responsabilidade Extracontratual do Estado apenas, pois que ao Estado não é possível ser atribuída outra forma de responsabilização, pelo menos nos mesmos parâmetros em que esta é atribuída às pessoas naturais.

Saliente-se que, no princípio, em épocas de governos absolutistas e despóticos, o entendimento pautava-se na irresponsabilidade do Estado, pois a figura do monarca era considerada a personificação do Estado e sua soberania advinha de um poder divino. Nessa linha de raciocínio, era inadmissível a ideia de que o monarca cometia erros que pudessem

\footnotetext{
${ }^{136}$ ARAUJO. Edmir Netto de. Curso de Direito Administrativo. 5. ed. São Paulo: Saraiva, 2010. p. 780.

${ }^{137}$ DI PIETRO, Maria Sylvia Zanella. Direito Administrativo. 24. ed. São Paulo: Atlas, 2011. p. 531.
} 
resultar em danos passíveis de ser indenizáveis. Ressalve-se, entretanto, que havia apenas a remota possibilidade de responsabilizar danos causados pelo funcionário público atuante.

Em um segundo estágio evolutivo da responsabilidade estatal, vislumbrou-se o Estado como responsável pelos atos culposos que seus prepostos praticassem em detrimento dos administrados. Restou superada a teoria da irresponsabilidade, admitindo-se, a partir de então, a responsabilidade do Estado por culpa, mas era necessário distinguir os atos de gestão e de império. Quando se tratava de danos ocasionados pela prática de atos de gestão, era plenamente possível a responsabilização estatal, mas quando os danos eram resultantes da prática de atos de império, o Estado não poderia ser responsabilizado. A dificuldade em se identificar a natureza do ato impossibilitava a reparação, então se abandonou a distinção entre a natureza dos atos para fins de responsabilização estatal e, assim, passou-se a adotar a teoria da culpa administrativa ou culpa anônima, ou ainda responsabilização pela falta do serviço, muito embora a responsabilização continuasse a se basear na ideia de culpa. Bastava a mera prova de que o serviço não funcionou, funcionou mal ou funcionou tardiamente, sendo, portanto, dispensável da culpa estatal - repita-se - a identificação individual do funcionário que praticou a conduta lesiva.

No terceiro e atual estágio evolutivo da responsabilidade do Estado, prevalece a teoria objetiva, desvinculada de qualquer ideia de culpa (dolo ou culpa em sentido estrito), admitida pelos diversos ordenamentos jurídicos. No Brasil, a teoria objetiva está positivada desde a Constituição Federal de 1.946. O ordenamento jurídico pátrio agasalhou a teoria objetiva pautada no risco administrativo, hipótese em que o Estado somente fica desobrigado de responsabilização quando houver incidência de causa excludente.

A Responsabilidade Civil, seja do Estado ou de particulares, é inerente à lógica do Estado de Direito, a qual submete todos ao império da lei. Além da legalidade, impõem-se, também, os princípios de igualdade e justiça.

Também não paira nenhuma dúvida quanto à obrigação do Estado de indenizar os prejuízos causados a terceiros, oriundos de suas atividades estatais; são, portanto, três elementos configuradores da responsabilidade do Estado: o fato administrativo, o dano (moral ou patrimonial) e, por fim, a existência do nexo de causalidade entre o fato administrativo e o resultado danoso.

A responsabilidade extracontratual do Estado independe da ilicitude ou não do comportamento do agente em sua conduta funcional, desde que não haja causa de exclusão da responsabilidade estatal. 
No capítulo seguinte, tratar-se-á da Responsabilidade do Estado por comportamentos omissivos, divorciando-a da responsabilidade por atos comissivos, que não é o foco da presente dissertação. 


\section{A RESPONSABILIDADE DO ESTADO POR OMISSÃO}

\subsection{O PAPEL DO ESTADO}

O Estado surgiu da restrição à liberdade natural e integral que o homem possuía na sua origem, em favor de um comando coordenador para a coletividade, como forma de obter melhores condições de vida ${ }^{1}$. A formação do Estado sofreu diversas transformações, evoluiu ao longo dos tempos até atingir o estágio atual, denominado de "Estado Moderno". Ou seja, uma sociedade política e juridicamente organizada com unidade territorial, dotada de soberania e composta de pessoas que se agrupam com um objetivo comum a ser atingido, o bem-estar geral.

Com a descoberta da escrita e o aperfeiçoamento cultural, o homem começou a escrever leis, normas e regras, ou seja, formulou-se um conjunto de preceitos que deveriam ser seguidos e acatados pela população em geral, pois consideravam que a união dos indivíduos em sociedade era a vontade geral e, por isso, suas leis também provinham da vontade popular.

Evidentemente, o principal motivo que levou os homens a se aglutinarem formando as primeiras células sociais foi o medo. Havia necessidade de proteger a família, a propriedade privada, os bens amealhados ao longo da vida, que eram saqueados sistematicamente, e havia, ainda, a necessidade de proteger a própria vida, pois na fase primitiva, as questões eram resolvidas pela força e a selvageria, sendo o mais fraco submetido e vencido sempre pelo mais forte. Diante da necessidade de nivelar os homens, na força, astúcia e inteligência, surgiram o contrato social e as leis.

Segundo os filósofos clássicos, o motivo pelo qual a Polis era tida como necessária devia-se ao fato de que somente dessa forma o homem poderia buscar a perfeição. Como consequência, ela (a Polis) era posta como primeira em relação ao indivíduo. Daí advinha também outra importante consequência, relativa à moralidade, segundo a qual o dever colocava-se em primeiro plano em relação ao direito. Concebia-se, assim, o indivíduo, independentemente de suas qualidades - e não como queria Aristóteles, que procurava a

\footnotetext{
${ }^{1}$ TRUJILLO, Elcio. Responsabilidade do Estado por atos Lícitos. São Paulo: LED Editora de Direito, 1996. p. 23.
} 
virtude - entendendo-se o homem como essencialmente completo, independente da sociedade civil, pois o estado natural em que o indivíduo vivia antecedia o estado civil.

Platão e Aristóteles desenvolveram uma teoria sobre a origem do homem, descrevendo-o como um ser dotado por natureza das condições para sobreviver em sociedade. Ao criar o homem incapaz de sobreviver sozinho e dotado de habilidades técnicas de sobrevivência, a Natureza obrigou-o a reunir-se aos seus semelhantes, de modo a constituir, por auxílio mútuo, relações de colaboração e de parentesco. Daí resultaram as primeiras associações ou comunidades, desde a família, até a aldeia e, finalmente, a Polis ou o Estado, onde, enfim, o homem pôde realizar-se, desenvolvendo seu potencial, justamente o objetivo maior da Natureza que o fez como um animal político racional (zoon politikon).

Conforme os ensinamentos de Aristóteles ${ }^{2}$,

Assim é evidente a razão pela qual o homem é um animal político, mais do que todos os demais, abelhas ou animais gregários. Como dissemos a natureza nada faz em vão; ora, o homem é o único entre todos os animais que é dotado de Logos [...] a palavra é feita para exprimir o útil e o prejudicial e, consequentemente, também, o justo e o injusto [...] e os outros valores; e é a posse comum desses valores que constitui a família e a polis.

Jean-Jacques Rousseau ${ }^{3}$, na segunda metade do século XVIII, parte do pressuposto de que o homem, em estado natural, participa de uma condição sem lei nem moralidade - O homem nasce livre, e por toda parte é acorrentado - e somente poderia viver em sociedade se firmasse um pacto de associação entre seus semelhantes. Tal pacto, longe de ser um pacto de submissão, deveria ser uma forma de associação que afastasse o uso da força, e que o protegesse e defendesse, pois, para o filósofo, seria impossível o homem retornar ao estado natural, convertido em estado civil a partir do advento do referido pacto. Nesse contexto, a vontade geral se sobrepunha à vontade do soberano. Nessa atmosfera nasceu "O Contrato Social", ideário para a Revolução Francesa e considerada uma das obras fundamentais da filosofia política, e também o marco para a criação do Estado moderno.

\footnotetext{
2 ARISTOTELES. A Política. Tradutor Nestor Silveira Chaves. Coleção Clássicos Edipro. 2.ed. São Paulo: Edipro, 2009. p. 58. Livro I.

${ }^{3}$ JEAN-JACQUES ROUSSEAU, filósofo iluminista, escritor, músico, compositor, teórico da Política, nascido em Genebra-Suíça (28/06/1712), morreu em Ermonville (02/07/1778), uma comuna francesa da região administrativa da Picardia, no departamento de Oise. O iluminismo ou movimento chamado de filosofia das luzes era caracterizado pela observância da ciência e da racionalidade crítica, que recusava todas as formas de dogmatismo, especialmente as doutrinas políticas e religiosas tradicionais. Rousseau publicou obras importantes para a Educação (Emílio ou Da Educação), para a política (O Contrato Social, Discurso sobre a origem da desigualdade entre os homens); Rousseau também escreveu um romance intitulado "A Nova Heloisa".
} 
Segundo Rousseau ${ }^{4}$

A família é a mais antiga das sociedades, e também a única natural; os mesmos filhos só ao pai se sujeitam enquanto necessitam dele para se conservar, e, finda a precisão, desprende-se o laço natural; isentos os filhos da obediência devida ao pai, isento este dos cuidados que requer a infância, todos ficam independentes. Se continuam a viver unidos, não é natural, mas voluntariamente, e só por convenção a própria família se mantém.

Os homens não têm capacidade de sobreviver individualmente, e aglutinar-se em grupos tornou-se mais do que necessário, passando a ser vital para a sobrevivência do ser humano. A partir do instante em que o indivíduo aceita viver em comunidade, abrindo mão de uma parcela de sua liberdade em favor do grupo, a moral é adicionada à conduta humana, e assim o instinto natural é suplantado pela noção de justiça e paz. A liberdade civil é limitada pela vontade geral, impossibilitando o desprezo ao direito alheio.

Nesse contexto, a figura do soberano se faz necessária, podendo ele ser representado por um indivíduo ou por um corpo político. Por analogia, o soberano, equivale ao pai, presente na célula familiar. A figura do soberano se mostra, assim, necessária, na medida em que, eleito pela maioria, representa a vontade de todos.

Os homens, no princípio, não tinham outros soberanos senão os deuses, nem outra regra senão aquelas baseadas nas normas teocráticas. O Imperador romano Calígula costumava afirmar que seria necessária uma grande mudança comportamental para que o homem se submetesse a outro semelhante, e, ainda, dele esperar o seu bem-estar.

Desse modo, a noção de pacto social anunciada por Rousseau era diametralmente distinta daquela apontada por Hobbes ${ }^{5}$ e John Locke . $^{6}$

$\mathrm{O}$ axioma fundamental no qual se assentava o pensamento de Thomas Hobbes era de que o maior mal que poderia afetar a vida humana é a morte violenta. E foi para evitá-la

\footnotetext{
${ }^{4}$ ROUSSEAU, Jean-Jacques. O Contrato Social. Tradução Pietro Nasseti. São Paulo: Martin Claret, 2004. p.24.

${ }^{5}$ THOMAS HOBBES foi um filósofo inglês nascido em Malmesbury (05/04/1588), que morreu em Hardwick Hall (04/12/1679); era também estudioso da Política e matemático. Escreveu várias obras, das quais destacam-se as mais importantes: Os elementos da lei, Leviatã e Do cidadão. Em Leviatã, Hobbes fez diversas considerações sobre a natureza humana e sobre a necessidade de criação de governos e sociedades; defendia a posição de que o homem, para viver em paz, deveria entregar parcela suficiente de sua liberdade natural a uma autoridade inquestionável. Afirmava que o homem, em estado natural, é mau, e sua natureza é destrutiva.

${ }^{6}$ JOHN LOCKE foi um filósofo inglês, nascido em Wringtown (29/08/1632), falecido em Harlow (28/10/1704), precursor do liberalismo. Suas considerações contribuíram para a queda do absolutismo na Inglaterra. O seu trabalho era fortemente contrário à doutrina de que as ideias eram inatas, ele não aceitava tal concepção e, a partir disso, desenvolveu sua teoria sobre a origem e a natureza do conhecimento (empirismo). Locke afirmava que todos os homens, ao nascer, detinham direitos naturais tais como a vida, a liberdade, e a propriedade, e que, para garantir esses direitos, foram criados os governos, entretanto quando os governos desrespeitam esses direitos, o povo pode se rebelar e não se sujeitar a tais decisões. Locke exerceu grande influência na eclosão das grandes revoluções (revolução inglesa, estadunidense e início da revolução francesa).
} 
que os homens, vivendo "lupinamente" no estado natural, ou seja, em um estado geral de beligerância, celebraram o Contrato Civil de não agressão, graças ao qual fundaram o Estado e a sociedade civil moderna.

Hobbes foi um estudioso atento e dedicado; teve a oportunidade de conhecer o melhor que havia em seu tempo, em termos de literatura e filosofia, e tudo isso fez com que ele fosse considerado o sucessor de Maquiavel $^{7}$. Herdando do filósofo italiano a paixão pelo Epicurismo $^{8}$, Hobbes foi considerado um epicurista moderno e fundador da política contemporânea; declarando-se inimigo da religião, foi banido da Corte de Londres, por causa da publicação de sua obra mais famosa, O Leviatã, encontrando asilo em Paris.

Leviatã ou Matéria, Forma e Poder de um Estado Eclesiástico e Civil, vulgarmente denominado apenas Leviatã é a obra escrita por Hobbes e publicada em 1.651. Esse título foi-lhe atribuído em referência ao monstro que aparece na bíblia cristã, no Livro de Jó, capítulo 41. Hobbes o toma como um deus mortal que pune o orgulho. O livro diz respeito à estrutura da sociedade e do governo legítimo, e é referenciado como um dos exemplos mais antigos e mais influentes da teoria do contrato social. Por vezes, é considerada uma das obras mais importantes já escritas acerca do pensamento político e, durante a Guerra Civil Inglesa, o autor defendeu um contrato social e o governo de um soberano absoluto (absolutismo).

Hobbes arfirmava que o caos ou a guerra civil - situações identificadas como um estado de natureza, e pelo famoso lema Bellum omnium contra omnes (guerra de todos contra todos) - só poderia ser evitado por um governo central forte.

Esse filósofo era obstinadamente contra a teoria teológica, que para ele dominava o homem pela implementação do terror e do medo. A quarta parte do Leviatã, capítulo XLIV,

\footnotetext{
${ }^{7}$ NICOLAU MAQUIAVEL nasceu e passou toda sua vida em Florença-Itália (03/05/1469 - 21/06/1527). Foi filósofo, historiador, poeta, diplomata e músico italiano do Renascimento. Desenvolveu teorias muito valorosas de como o Estado deveria ser; por seu estilo crítico, foi muito mal interpretado, tendo, inclusive, originado o adjetivo maquiavélico, criado a partir do seu nome, que significa esperteza, astúcia, aleivosia, maldade. Maquiavel era epicurista fanático tendo, inclusive, traduzido a obra Rerum Natura, de Lucrécio (94-55 a.C.). Sua obra mais famosa é "O Princípe", escrita em 1.513, mas publicada somente em 1532, após a morte do escritor, descrevendo as maneiras de conduzir-se nos negócios públicos internos e externos e, fundamentalmente, como conquistar e manter um principado. Este livro sugere a famosa expressão os fins justificam os meios, significando que não importa o que o governante faça em seus domínios, desde que seja para manter-se como autoridade, entretanto a expressão não se encontra no texto, mas tornou-se uma interpretação tradicional do pensamento maquiavélico.

${ }^{8}$ EPICURISMO foi uma escola filosófica fundada por Epicuro de Samos no ano de 306 a.C. em Atenas. Suas características, que têm em comum com as demais correntes filosóficas de período Alexandrino a preocupação de subordinar a investigação filosófica à exigência de garantir a tranquilidade do espírito ao homem, são as seguintes: $1^{\circ}$ ) sensacionismo, princípio segundo o qual a sensação é o critério da verdade e do bem (este último identificado, portanto, com o prazer); $2^{\circ}$ ) atomismo, com o que Epicuro explicava a formação e a transformação das coisas por meio da união e da separação dos átomos, e o nascimento das sensações como ação dos estratos de átomos provenientes das coisas sobre os átomos da alma; $3^{\circ}$ ) semiateísmo, pelo qual Epicuro acreditava na existência dos deuses, que, no entanto, não desempenham papel nenhum na formação e no governo do mundo.
} 
tem como título "Do Reino das Trevas" e trata exatamente da teologia cristã que Hobbes buscava destruir.

De sua obra também se deduz que a função do Estado não era, como queriam os gregos, promover a virtude ou a excelência do cidadão, mas simplesmente a garantia da segurança e do direito natural de todos os indivíduos.

Outro filósofo defensor do "contrato social" era John Locke, que via no homem seu estado natural, forjado pela natureza, e acreditava que, nesse estado, o indivíduo tende a entrar em conflito com facilidade. Para Locke, o ser humano possui a capacidade de se organizar socialmente mediante um "pacto"; opondo-se a Hobbes, defendia um regime de governo democrático, criado para garantir os direitos naturais. Se esses governos, contudo, não respeitassem a vida, a liberdade e a propriedade, o povo tinha o direito de se revoltar contra eles. As pessoas podiam contestar um governo injusto e não eram obrigadas a aceitar suas decisões. Locke era um ferrenho crítico da tradição que afirmava o direito divino dos reis, declarando que a vida política é uma invenção humana, completamente independente das questões divinas.

Acompanhando a marcha da história, em 1.748, Montesquieu9 ${ }^{9}$, fascinado pelo progresso das Ciências e de suas descobertas a respeito das leis que regiam o mundo físico, tratadas diversas vezes em seus ensaios, propõe que a realidade social, assim como a natureza, também deveria ser regida por leis. Empolgado, passou a estudar detidamente as relações humanas para desvendar as leis sociais. Por ser um homem rico, Montesquieu viajou muito e isso lhe assegurou que tomasse conhecimento dos vários problemas sociais da Europa, além de ter sido um grande leitor e conhecedor dos impérios antigos, tais como: Roma, Grécia, Cartago, Egito, Pérsia, China, Macedônia, Japão e os povos Hebreu, Árabe, Turco, dentre outras etnias e países.

Neste contexto, Montesquieu elaborou uma teoria política, inspirada em John Locke e em seus estudos sobre as instituições políticas inglesas. Seguindo seus passos na teorização da separação dos poderes, ele retomou Aristóteles, acrescentando à teoria da separação dos poderes, a função judiciária. Para Montesquieu, o Estado deveria ser dividido em três poderes, cada um com funções específicas. Tal teoria se concretizou na obra mais

\footnotetext{
${ }^{9}$ CHARLES-LOUIS DE SECONDAT, Baron de la Brède et de Montesquieu, nasceu em Bordéus em 18/01/1689 e morreu em Paris no dia 10/02/1755; foi escritor, filósofo e político. Iniciou seus estudos na área do direito romano, biologia, física e geologia. Com esses conhecimentos, Montesquieu pôde se aprofundar no estudo iluminista, aliando as ciências naturais e as questões humanas.
} 
famosa do filósofo francês, intitulada "O Espírito das Leis ${ }^{10 "}$ (título orginal- " $L$ 'spirit des lois"), trabalho que se tornou referência universal para advogados, legisladores e outros cientistas sociais.

A obra faz um vasto estudo nas áreas de direito, história, economia, geografia e teoria política; nela se discute a respeito das instituições e das leis, e busca-se compreender as diversas legislações existentes em diferentes lugares e épocas. Essa obra inspirou os redatores da Constituição de 1791 e tornou-se fonte das doutrinas constitucionais liberais, que têm na separação dos poderes legislativo, executivo e judiciário, a base do Estado de Direito.

As leis foram criadas para proteger o homem, sua família e seus bens, harmonizando as relações.

Nas considerações de Cesare Beccaria ${ }^{11}$,

Leis são condições sob as quais homens independentes e isolados se uniram em sociedade, cansados de viver em contínuo estado de guerra e de gozar de uma liberdade inútil pela incerteza de conservá-la. Parte dessa liberdade foi por eles sacrificada para poderem gozar o restante com segurança e tranquilidade. A soma de todas essas porções de liberdades, sacrificadas ao bem de cada um, forma a soberania de uma nação, e o Soberano é seu legítimo depositário e administrador.

Ihering $^{12}$, por sua vez, considerava que:

A conservação da própria existência é a lei suprema de todo o Universo; na busca da autopreservação, ela está em todas as criaturas.

Mas para o homem não se trata apenas da vida física, mas também de sua existência moral, cuja necessidade é a conservação do direito.

O ser humano, através do direito, possui e defende sua existência moral sem direito, ele se rebaixaria até os animais, como já faziam os romanos, que, do ponto de vista do direito abstrato, nivelavam os escravos aos irracionais.

Roberto Dromi ${ }^{13}$, tratando da "relocalización del Estado", aponta que o Estado "relocalizado" deve ser orientador, organizador, administrador, planificador, servidor,

\footnotetext{
${ }^{10}$ MONTESQUIEU, Charles de Secondat, Baron de. Do Espirito das Leis. Tradução Roberto Leal Ferreira. São Paulo: Martin Claret, 2010.

${ }^{11}$ BECCARIA, Cesare. Dos Delitos e Das Penas. Tradução de José Cretella Jr. e Agnes Cretella. 3. ed. São Paulo: Revista dos Tribunais, 2006. p. 21.

${ }^{12}$ IHERING, Rudolf Von. A Luta pelo Direito. Tradução José Cretella Jr. e Agnes Cretella. 5. ed. São Paulo: Revista dos Tribunais, 2008. p. 51.

${ }^{13}$ DROMI, Roberto. Derecho Administrativo. 5.ed. Argentina: Ciudad Argentina, 1996. p. 45-49.
} 
fiscalizador, protetor, garantidor, regulador e distribuidor. Isso significa que o Estado Moderno assumiu um novo papel no contexto atual, bem como novas missões.

O Estado orientador é aquele que tem a titularidade, o exercício e a tutela da condução política da sociedade com a finalidade de atingir o bem comum.

$O$ Estado organizador deve estabelecer as regras que definem a ordem, a harmonia e a independência do todo que compõe o "todo social", não apenas a organização estrutural e funcional de seus órgãos, mas de toda a sociedade.

O Estado administrador é aquele que executa direta e indiretamente ou deixa executar prestações e serviços públicos, exercendo por meio da administração indireta ou de sujeitos privados, a função administrativa (atividade de gestão e serviços) visando o bem-estar geral.

O Estado planificador está alicerçado sobre o princípio da planificação, que nasceu no bojo da reforma do Estado e está contemplado no texto constitucional argentino, se configurando naquele que tem o dever de elaborar os planos e projetos de ação governamental e executá-los. A planificação não é apenas uma operação técnica: é, essencialmente, segundo critério apontado por Dromi, um processo político, por meio do qual se define o que a sociedade deseja em longo prazo, para projetar em curto e médio prazo.

O Estado servidor é assim definido porque está a serviço de seu mandante - o povo - , devendo cuidar dos interesses da sociedade, satisfazendo, assim, suas necessidades.

O Estado fiscalizador se mostra por meio de suas funções essenciais: governo e controle. O controle é coexistencial ao Estado, e controlar não é reduzir direitos, mas compatibilizá-los e harmonizá-los para a possibilitar a convivência social.

Estado protetor é aquele que cuida dos interesses da comunidade, amparando e defendendo os administrados, nos termos de sua Constituição.

Estado garantidor é aquele que responde subsidiária, excepcional e solidariamente, sendo a "reserva" e a "garantia de relevo" da comunidade e ainda seu fiador, podendo intervir de forma substitutiva e conjuntural.

Estado regulador ajusta a convivência social aos princípios e regras de convivência social e desenvolvimento individual.

E, finalmente, há que se fazer referência ao Estado distribuidor, que é o papel pelo qual o Estado deve fazer acontecer a justiça social, dando a cada um aquilo que lhe pertence, segundo a medida de seu direito, sendo árbitro e juiz da justiça social, pois tem poder e dever de repartir os benefícios comuns. 
Tais considerações se prestam para elucidar o objetivo para o qual o Estado foi concebido, e qual é, verdadeiramente, seu papel dentro do contexto social. Como ente depositário daquela parcela de liberdade outorgada pelos cidadãos mediante a celebração do "Contrato Social", a existência do Ente Estatal se faz imprescindível para que haja convívio comunitário harmônico e equilibrado, não podendo furtar-se de seu dever de agir, hipótese que se concretiza quando o Estado se ausenta ou se furta do dever de cumprir seu papel.

\subsection{DANOS CAUSADOS PELA OMISSÃO DO ESTADO}

A submissão do Estado ao império das leis - obrigando a observância de um ordenamento jurídico preestabelecido e o reconhecimento dos direitos individuais, garantias contra os abusos e desmandos do Estado anteriormente absolutista - acarretou o surgimento do Direito Administrativo como ciência autônoma. A partir daí, as relações entre os particulares e o Estado e deste com seus agentes começaram a se estruturar juridicamente mediante o conjunto de normas estáveis.

Por uma razão de ordem lógica, considerar que a responsabilidade do Estado por omissão decorre de comportamento ilícito induz à conclusão de que é necessária a prova de culpa.

Na Teoria Pura do Direito, Kelsen nos ensina que "a função essencial de um ordenamento coercitivo como o do direito, não pode ser outra coisa a não ser a ligação normativa dos indivíduos a ele submetidos ${ }^{14}$ ".

O estudo da responsabilidade do Estado por comportamento omissivo alberga amplo campo de debate jurídico, sobretudo no que diz respeito à aplicação da teoria objetiva, como já dissemos. Primeiramente, é necessário compreender que a omissão estatal decorre de comportamento ilícito, configurado pela inércia, pois só é possível a verificação da omissão quando existir o dever de agir por parte do Estado ou a possibilidade de agir ${ }^{15}$. A dificuldade da teoria diz respeito à possibilidade de agir, pois deve haver configuração em conduta que seja exigível e possível.

\footnotetext{
${ }^{14}$ KELSEN, Hans. Teoria Pura do Direito. Tradução de José Cretella Jr. e Agnes Cretella. 3. ed. São Paulo: Revista dos Tribunais, 2002. p. 84.

${ }^{15}$ DI PIETRO, Maria Sylvia Zanella. Direito Administrativo. 24. ed. São Paulo: Atlas, 2011. p.655.
} 
Celso Antônio Bandeira de Mello ${ }^{16}$ aponta três tipos de situações ensejadoras de responsabilização estatal; a primeira se consubstancia na ação, circunstância que exige a aplicação da teoria objetiva; a segunda situação se baseia na omissão, que segundo a doutrina majoritária é suscetível à teoria subjetiva; e por derradeiro, as situações produzidas pelo Estado diretamente propiciatórias de dano, que se equiparam à conduta comissiva.

A responsabilidade estatal configura-se no dever de se reparar uma lesão causada a alguém, usuário do serviço público ou não, oriundo de ação ou omissão culposa ou dolosa. Sua natureza é patrimonial e de dispositivo contido originariamente no Código Civil, de maneira que aquele que viola direito, ou causa prejuízo a outrem, por ação ou omissão voluntária, negligência, ou imprudência, queda-se obrigado a indenizar.

Comando legal contido no artigo 159 do Código Civil Brasileiro de 1916, que no novo Código Civil, de 10 de janeiro de 2002, cuja entrada em vigor ocorreu um ano após a sua publicação, corresponde ao artigo 186, determina que "Aquele que, por ação ou omissão voluntária, negligência ou imprudência, violar direito ou causar dano a outrem, ainda que exclusivamente moral, comete ato ilícito". Combinado com o artigo 927, tem-se que: "Aquele que, por ato ilícito, causar dano a outrem, fica obrigado a repará-lo" .

A reparação do dano causado pela Administração a terceiros obtém-se amigavelmente ou por meio de ação de indenização, e, uma vez indenizada a lesão da vítima, fica a entidade pública com o direito de voltar-se contra o servidor culpado, para haver dele o despendido, por meio de ação regressiva autorizada pelo art. $37, \S 6^{\circ}$, da CF. O legislador constituinte bem separou as responsabilidades: o Estado indeniza a vítima; o agente indeniza o Estado, regressivamente ${ }^{17}$.

São indenizáveis os danos certos, anormais e especiais, quando se está diante de atividades lícitas. Se ilícitas, bastaria fossem certos os danos e atingissem situações jurídicas constituídas.

Celso Antônio Bandeira de Mello ${ }^{18}$, seguindo os passos de Osvaldo Aranha Bandeira de Mello, sustenta que quando o dano foi possível em decorrência de uma omissão do Estado, hipótese em que o serviço não funcionou, funcionou tardia ou ineficientemente, aplicar-se-á a teoria da responsabilidade subjetiva. Pois bem, se o Estado não agiu, não pode

\footnotetext{
${ }^{16}$ BANDEIRA DE MELLO, Celso Antonio. Curso de Direito Administrativo. 28. ed. São Paulo: Malheiros, 2010. p. 1018.

${ }^{17}$ MEIRELLES, Hely Lopes. Direito Administrativo Brasileiro. 37. ed., atualizada por Eurico Andrade Azevedo, Décio Balestero Aleixo e José Emmanuel Burle Filho. São Paulo: Malheiros, 2011. p. 708.

${ }^{18}$ BANDEIRA DE MELLO, Celso Antônio. Op. cit.. p. 1021.
} 
ser ele o autor do dano. E, se não foi o autor, só cabe responsabilizá-lo caso esteja obrigado a impedir o dano. Ou seja, só faz sentido responsabilizá-lo se descumpriu dever legal que lhe impunha obstar ao evento lesivo.

O referido doutrinador aponta como exemplo de acontecimentos suscetíveis de acarretar responsabilidade estatal por omissão ou atuação ineficiente: a) fato da natureza a cuja lesividade o Poder Público não obstou, embora devesse fazê-lo; e b) comportamento material de terceiros cuja atuação lesiva não foi impedida pelo Poder Público, embora pudesse e devesse fazê-lo.

Para Irene Patrícia Nohara ${ }^{19}$, o tema ainda não foi pacificado, havendo grande divergência no campo doutrinário e jurisprudencial, conforme destaca :

[...] O regime de responsabilização do Estado quando os danos são causados pela sua omissão é um dos temas mais polêmicos do assunto. Há diversos posicionamentos, tanto na doutrina como na jurisprudência, sobre o tipo de responsabilidade decorrente da omissão do Estado, se objetiva, ou independente de culpa, ou se subjetiva, hipótese que se abre para a discussão da culpa do serviço (faute du service), que compreende três circunstâncias: o não funcionamento, o funcionamento mau ou tardio do serviço que causa danos.

A responsabilização por omissão pode ser em razão do não funcionamento de um serviço, do funcionamento tardio ou da ineficiência. Evidencia-se essa espécie de situação em que, por lei, o Estado é obrigado a agir de determinada maneira, contudo não pratica a conduta, devendo indenizar os prejuízos oriundos de sua desídia.

No magistério de Marçal Justen Filho ${ }^{20}$, há casos em que o direito determina a conduta que o Estado deve tomar. Cita, sob esse enfoque, a situação em que a Lei prevê que o Estado deve interditar um estabelecimento comercial que não tiver autorização para funcionar. A situação é semelhante à natureza da atuação comissiva, haja vista que deixar de agir quando a lei ordena é o mesmo que agir quando a lei proíbe.

Ainda, no que diz respeito à responsabilidade omissiva, o referido autor afirma que o núcleo dos problemas é aquele em que não há norma explícita a respeito do dever de agir, mas o agir, em tese, seria o meio para evitar a ocorrência de um evento danoso. Tome-se, por exemplo, a hipótese em que o servidor deixa de colocar sinalização indicando defeito de pavimentação em via pública, ocasionando acidente automobilístico. Na realidade, não há

\footnotetext{
${ }^{19}$ NOHARA, Irene Patrícia. Direito Administrativo. São Paulo: Atlas, 2011. p. 774.

${ }^{20}$ JUSTEN FILHO, Marçal. Curso de Direito Administrativo. São Paulo: Saraiva, 2005. p. 801.
} 
dever de agir, entretanto a ação se fundamenta no dever de diligência que presta o funcionário em determinada função pública.

Alguns doutrinadores estabelecem distinção entre responsabilidade por omissão lícita e responsabilidade por omissão ilícita.

Entendemos que não há que se falar em tal distinção, e tal discussão é inócua, pois é perfeitamente possível que uma ação ou omissão lícita do Estado cause prejuízo a outrem, portanto o comportamento estatal não precisa ser necessariamente ilícito para que os pressupostos configuradores da responsabilidade sejam atendidos.

O caráter objetivo da responsabilidade pela omissão estatal é aceito por grande parte da doutrina, não obstante sua concretização ser limitada. O caráter geral de tal responsabilidade é consentâneo com a evolução do instituto da responsabilidade extracontratual do Estado.

O risco da aplicação efetiva da responsabilidade do Estado por omissão deve assumir o papel de garantir o dever da boa administração, diligente e eficiente, cuja atuação se pauta pelos princípios de competência e de legalidade, e deve estar pronta para assumir as consequências do seu comportamento.

No que tange à jurisprudência, verificamos que a questão da responsabilização do Estado por omissão ainda não está totalmente pacificada. No próprio STF há juristas que são adeptos da teoria objetiva e outros filiados à teoria subjetiva, conforme veremos mais adiante.

\subsubsection{Divergências doutrinárias}

Alguns doutrinadores defendem a ideia de que a responsabilidade do Estado por omissão seria de natureza objetiva, enquanto outros a refutam, dizendo que tal responsabilização é de cunho subjetivo, isto é, depende de culpa.

O prejuízo experimentado pelo particular, oriundo da ação ou omissão do Estado é fato jurídico, vez que devidamente normatizado pelo $\S 6^{\circ}$ do art. 37 da Constituição Federal vigente. $\mathrm{O}$ fato jurídico não é a conduta ou o comportamento (ação ou a omissão), mas sim o dano resultante desta ou daquela conduta. 
Maria Sylvia Zanella Di Pietro sustenta que, na hipótese de omissão, a responsabilidade do Estado é subjetiva, porque decorre do mau funcionamento do serviço público $^{21}$.

Na mesma trilha segue Diógenes Gasparini ${ }^{22}$, argumentando que o disposto no art. $37, \S 6^{\circ}$, determina que para a configuração da responsabilidade objetiva do Estado é necessário que haja uma ação do agente público, haja vista a utilização do verbo "causar" (causarem):

Art. 37

$\S \mathbf{6}^{\mathbf{0}}$ As pessoas jurídicas de direito público e as de direito privado prestadoras de serviços públicos responderão pelos danos que seus agentes, nessa qualidade, causarem a terceiros, assegurado o direito de regresso contra o responsável nos casos de dolo ou culpa (grifo nosso).

[...] Nesses casos, a culpa do Estado é presumida, invertendo-se, portanto, o ônus da prova. Sendo assim, não haverá responsabilidade objetiva por atos omissivos, devendo a vítima, nestes casos, provar a culpa do Estado, pois sua responsabilidade é subjetiva.

Conforme mencionado no item anterior, Celso Antônio Bandeira de Mello ${ }^{23}$, acompanhado por Maria Helena Diniz ${ }^{24}$, fazendo eco às lições de Osvaldo Antônio Bandeira de Mello, tem a mesma posição de Maria Sylvia Zanella Di Pietro, ou seja, quando os danos são provocados em virtude da omissão do Estado, Celso Antônio entende que a responsabilidade é subjetiva, defendendo sua posição ao afirmar que,

Quando o dano foi possível em decorrência de uma omissão do Estado (o serviço não funcionou, funcionou tardia ou ineficientemente) é de aplicar-se a teoria da responsabilidade subjetiva. Com efeito, se o Estado não agiu, não pode, logicamente, ser ele o autor do dano. E se não foi o autor, só cabe responsabilizá-lo caso esteja obrigado a impedir o dano. Isto é: só faz sentido responsabilizá-lo se descumpriu dever legal que lhe impunha obstar o evento lesivo [...]; a responsabilidade estatal por ato omissivo é sempre responsabilidade por comportamento ilícito. E sendo responsabilidade por ilícito é necessariamente responsabilidade subjetiva, pois não há conduta ilícita do Estado (embora do particular possa haver) que não seja proveniente

\footnotetext{
${ }^{21}$ DI PIETRO, Maria Sylvia Zanella. Direito Administrativo. 24. ed. São Paulo: Atlas, 2011. p. 654-655.

22 GASPARINI, Diógenes. Direito Administrativo. 17. ed. São Paulo: Saraiva, 2012. p. 1.141.

${ }^{23}$ BANDEIRA DE MELlo, Celso Antônio. Curso de Direito Administrativo. 28. ed. rev., atual. e ampl. São Paulo: Malheiros. 2011. p. 1021.

${ }^{24}$ DINIZ, Maria Helena. Curso de Direito Civil Brasileiro, Responsabilidade Civil. $7^{\circ}$ volume. 19.ed. São Paulo: Saraiva, 2004. p. 628.
} 
de negligência, imprudência ou imperícia (culpa) ou, então, deliberado propósito de violar a norma que o constituía em dada obrigação (dolo). Culpa e dolo são justamente as modalidades de responsabilidade subjetiva. Em outras palavras: é necessário que o Estado haja incorrido em ilicitude, por não ter acorrido para impedir o dano ou por haver sido insuficiente neste mister, em razão de comportamento inferior ao padrão legal exigível.

Na concepção de José Maria Pinheiro Madeira, "A responsabilidade civil da Administração Pública poderá ocorrer sob as seguintes formas: subjetiva (por meio de atos ilícitos omissivos) ou objetiva ou do risco administrativo, nas variantes de ato lícito, de risco suscitado e ato ilícito comissivo, que é o normal" 25.

A aplicação da teoria subjetiva nas hipóteses de omissão já foi sustentada há muito tempo atrás por Osvaldo Antônio Bandeira de Mello: “[...] No entanto, foi refutado por Toshio Mukai, ao fundamento de que "as obrigações, em direito, comportam causas, podendo elas ser a lei, o contrato ou o ato ilícito" 26.

José dos Santos Carvalho Filho ${ }^{27}$, compartilhando da posição de Celso Antônio Bandeira de Mello, considera que Responsabilidade por conduta omissa é de ordem subjetiva, uma vez que a esta somente se desenhará quando presentes os pressupostos que caracterizem a culpa.

Lúcia Valle Figueiredo ${ }^{28}$ também aderiu ao mesmo pensamento:

No tocante aos atos ilícitos decorrentes de omissão, devemos admitir que a responsabilidade só poderá ser inculcada ao Estado se houver prova de culpa ou dolo do funcionário. Esta é a posição do Prof. Celso Antonio Bandeira de Mello e do ilustre, querido e saudoso mestre Osvaldo Aranha Bandeira de Mello.

[...] Não há como provar a omissão do Estado sem antes provar que houve faute de service. É dizer: não ter funcionado o serviço, ter funcionado mal ou tardiamente.

Contrária à já citada posição ostentada por Celso Antônio Bandeira de Mello, é aquela adotada por José Cretella Júnior, para quem "se o serviço não funcionou, ou funcionou mal ou se funcionou com atraso, tem-se a culpa do serviço, acarretando a responsabilidade civil do Estado por defeito ou falha do serviço público.

\footnotetext{
${ }^{25}$ MADEIRA, José Maria Pinheiro. Administração Pública. TOMO II. 11.ed. Rio de Janeiro: Elsevier, 2010. p. 265.

${ }^{26}$ GONÇALVES, Carlos Roberto. Responsabilidade Civil. 13. ed. São Paulo: Saraiva. 2011, p. 220.

${ }^{27}$ CARVAlHO FILHO, José dos Santos. Manual de Direito Administrativo. São Paulo: Atlas, 2012. p. 561.

${ }^{28}$ FIGUEIREDO, Lúcia Valle. Curso de Direito Administrativo. 7. ed. São Paulo: Malheiros, 2004. p. 269.
} 
[...] No fundo, o não-funcionamento ou mau funcionamento do serviço, com falha ou atraso, está relacionado com a ação ou a omissão do agente administrativo que, de modo direto ou indireto, deveria ter diligenciado para que o serviço se apresentasse perfeito. Mesmo, porém, que não se apure a identidade do agente responsável pelo mau funcionamento do serviço público, basta a prova inequívoca do prejuízo ocasionado, como decorrência da falha da máquina do Estado (nexo causal), para empenhar a responsabilidade administrativa da pessoa jurídica pública a quem está afeto o serviço e a respectiva indenização patrimonial, o que, em outras palavras, significa que, superada a teoria subjetiva, que pressupõe a identificação do agente causador do dano, o direito administrativo chega à teoria objetiva, que prescinde da culpa do homem, da identificação do funcionário, fixando-se na falha do serviço ${ }^{29}$.

Não é somente a ação que pode produzir danos; omitindo-se, o agente público também pode causar prejuízos aos administrados e à própria administração. A omissão configura a culpa in vigilando e a culpa in omittendo. São casos de inércia ou de "não atos". Cruzam-se os braços, não há vigilância, quando deveria agir, não agiu.

Oportuna se torna a observação de Mônica Nicida Garcia, propagando que:

[...] não tem pertinência, de outra parte, a invocação da tese da faute de service, inspirada no direito francês. Como anteriormente demonstrado, na França, apesar de ser amplamente aceita a responsabilidade objetiva do Estado, não tem ela estrutura constitucional, sendo reconhecida caso a caso, e, em algumas situações específicas, por leis também específicas. Por isso que, lá, a aplicação da teoria da culpa do serviço é absolutamente consentânea com o ordenamento jurídico vigente. Não aqui, porém, onde a Constituição expressamente prevê que a responsabilidade do Estado é objetiva, sem qualquer distinção entre atos comissivos e omissivos ${ }^{30}$.

Também é a posição sustentada por Álvaro Lazzarini ${ }^{31}$, Edmir Netto de Araújo ${ }^{32}$, Hely Lopes Meirelles ${ }^{33}$, Mário Masagão ${ }^{34}$ e Onofre Mendes Júnior ${ }^{35}$.

\footnotetext{
${ }^{29}$ CRETELLA JÚNIOR, José. O Estado e a Obrigação de Indenizar. 2. ed. Rio de Janeiro: Forense, 2002. p. 79.

${ }^{30}$ GARCIA, Mônica Nicida. Responsabilidade do Agente Público. 2.ed. revista e ampliada. Belo Horizonte: Fórum, 2007. p. 190.

${ }^{31}$ LAZZARINI, Álvaro. Estudos de Direito Administrativo. 2. ed. São Paulo: Revista dos Tribunais, 1999. p. 420.

${ }^{32}$ ARAÚJO, Edmir Netto de. Curso de direito administrativo. 5. ed. São Paulo: Saraiva. p. 791.

${ }^{33}$ MEIRELLES, Hely Lopes. Direito Administrativo Brasileiro. 37. ed. São Paulo: Malheiros, 2011. p. 706.

${ }^{34}$ MASAGÃO, Mário. Curso de Direito Administrativo. 3. ed. São Paulo: Max Limonad, 1960. p. 312 e 316.

${ }^{35}$ MENDES JÚNIOR, Onofre. Natureza da responsabilidade administrativa pública. Belo Horizonte: Del Rey, 1951. p. 142.
} 
Paulo Modesto ${ }^{36}$ explica que:

Nos casos de omissão, de que decorra dano imputável ao Estado, ao prejudicado incumbe apenas provar a efetividade, a especialidade e antijuridicidade do dano sofrido e o vínculo de imputação entre inação estatal e o dano causado. Não se lhe deve exigir nem mesmo a prova de descumprimento do dever de cuidado que qualifica a omissão como antijurídica. Cabe-lhe simplesmente provar a efetividade e ilegitimidade do dano suportado e o vínculo que o liga ao Estado.

Sérgio Cavalieri Filho ${ }^{37}$ entende que o aludido art. $37, \S 6^{\circ}$, da $\mathrm{CF} / 88$ não se refere apenas à atividade comissiva do Estado; pelo contrário, a ação a que alude o referido dispositivo engloba tanto a conduta comissiva como omissiva. No que diz respeito à conduta comissiva, não há dúvida, a responsabilidade é objetiva. Entretanto, analisando a conduta omissiva, o referido doutrinador faz uma distinção entre omissão genérica e omissão específica. A omissão específica é aquela que ocorre quando o Estado, por sua omissão, cria a situação propícia para a ocorrência do evento em situação em que tenha o dever de agir para impedi-lo, somente nessa hipótese seria admissível a aplicação da teoria objetiva.

Cavalieri Filho, ilustrando suas explicações, cita o caso de veículo muito velho que, sem condições normais de trânsito, causa um acidente por defeito de freio ou falta de luz na traseira. A Administração não pode ser responsabilizada pelo fato de a viatura ainda estar circulando. Isso seria a omissão genérica. Mas se esse veículo foi liberado numa vistoria, ou passou pelo posto de fiscalização sem problemas, aí já teremos a omissão específica.

Marçal Justen Filho ${ }^{38}$, referindo-se ao dano resultante da omissão estatal, distingue tal omissão em duas categorias - o ilícito omissivo próprio e o impróprio. A primeira categoria diz respeito aos casos em que uma norma prevê o dever de atuação e a omissão corresponde à infração direta ao dever jurídico (ilícito omissivo próprio) equiparando-se aos atos comissivos. A segunda categoria se refere às situações nas quais o sujeito não está obrigado a agir de modo determinado e específico, nesse caso a omissão do agente não gera a presunção de infração de um dever de diligência (ilícito omissivo impróprio), não havendo, dessa forma, como imputar responsabilidade ao Estado. Assim, a teoria objetiva somente seria aplicável na hipótese de ilícito omissivo próprio.

\footnotetext{
${ }^{36}$ MODESTO, Paulo. Responsabilidade do Estado pela demora na prestação jurisdicional. In: Revista Diálogo Jurídico, $\mathrm{n}^{\circ}$ 1, 2001. Disponível em: <www.direitopublico.com.br>. Acesso em: 09 nov. 2012.

${ }^{37}$ CAVALIERI Filho, Sérgio. Programa de Responsabilidade Civil. 9. ed. São Paulo: Atlas, 2010. p. 251-252.

${ }^{38}$ JUSTEN FILHO, Marçal. Curso de Direito Administrativo. São Paulo: Saraiva, 2005. p. 800.
} 
Yussef Said Cahali ${ }^{39}$, aderindo à teoria da responsabilidade objetiva, assevera que:

No plano da responsabilidade objetiva, o dano sofrido pelo administrado tem como causa o fato objetivo da atividade (comissiva ou omissiva) administrativa, regular ou irregular, incompatível, assim, com qualquer concepção de culpa administrativa, culpa anônima do serviço, falha ou irregularidade no funcionamento deste.

Weida Zancaner Brunini ${ }^{40}$, argumentando sobre a evolução da responsabilidade estatal, entende que a adoção da teoria objetiva proporciona uma garantia mais ampla dos direitos dos cidadãos, assumindo importância vital para o estudo da responsabilidade do Estado; realmente, a teoria objetiva é a que deve prevalecer na relação Administrado-Estado, contudo a teoria subjetiva restará aplicável somente na relação Estado-funcionários, quanto ao direito de regresso do Estado contra seu agente, pois condicionada à culpabilidade deste.

A inércia do Estado - abstendo-se, este, de realizar as tarefas a que por lei está obrigado - frequentemente acaba por causar prejuízos ao patrimônio jurídico individual, material ou moralmente. Dessa forma, já não são mais aceitáveis os argumentos no sentido de afastar do Estado o dever de responder pelos danos causados por sua inação, objetivamente, como determinado pelo preceito constitucional aplicável à espécie.

Por fim, concluímos que, considerando que o artigo 43 do Código Civil adotou a responsabilidade objetiva para ambas as modalidades de atos (comissivos e omissivos), aliado ao fato de o artigo $37, \S 6^{\circ}$, da $\mathrm{CF} / 88$ atribuir a responsabilidade objetiva para os atos da administração Pública, sem distinguir os omissivos e os comissivos, apesar das divergências doutrinárias e jurisprudenciais, não se pode negar que a responsabilidade do Estado pode ser entendida como a obrigação do Estado de evitar, ressarcir, reparar ou recompor o patrimônio lesionado, material ou imaterial, individual ou coletivo, por danos causados a terceiros, usuários ou não do serviço público, por ação ou omissão independente de dolo ou culpa do agente. Não faz sentido separar os critérios para condutas omissivas e comissivas.

\footnotetext{
${ }^{39}$ CAHALI, Yussef Said. Responsabilidade Civil do Estado. 3. ed. São Paulo: Revista dos Tribunais, 2007. p. 35.

${ }^{40}$ ZANCANER BRUNINI, Weida. Responsabilidade extracontratual da administração pública. São Paulo: Revista dos Tribunais, 1981. p. 32.
} 


\subsubsection{A Doutrina Estrangeira}

Não é tarefa fácil buscar elementos na doutrina alienígena a fim de enriquecer uma pesquisa, pois as barreiras são quase intransponíveis, começando pela indigência bibliográfica nacional e internacional ${ }^{41}$. O método comparativo é reconhecido em todo o universo jurídico; a comparação dos diversos sistemas permite que se compreendam todos e cada um dos institutos confrontados, ao mesmo tempo que esclarece, de modo direito e profundo, o próprio sistema em que se integra o estudioso que se utiliza desse instrumento ${ }^{42}$.

Entretanto adverte Álvaro Lazzarini ${ }^{43}$ que há de se ter cuidado, pois é necessário que o estudioso conheça também as fontes do direito, no país pesquisado, sob pena de exporse a erros grosseiros, e ainda, referindo-se à advertência feita por Jean Rivero, na sua obra Droit Administratif Comparé, “o estudo dos textos não basta. É preciso ver e viver a instituição, enfim, não basta o ponto descritivo dado pela legislação, assim, estático e superficial" .

A Constituição da República Popular da China, aprovada em 4 de dezembro de 1.982, corroborando a Constituição da antiga União da Repúblicas Socialistas Soviéticas URSS, prevê o direito do cidadão de criticar e acusar qualquer órgão ou funcionário do Estado, por violação da lei ou negligência, garantindo, também, o direito à indenização correspondente ${ }^{44}$.

A Constituição da República de Cuba, proclamada em 24 de fevereiro de 1.976, no artigo 26, estabelece que: “Toda pessoa que sofreu dano ou prejuízo causado indevidamente por funcionários ou agentes do Estado, por motivo do exercício das funções

\footnotetext{
${ }^{41}$ José Cretella Júnior, o único doutrinador brasileiro a escrever sobre o Direito Administrativo Comparado, destacava que o método comparativo é instrumento muito delicado que precisa ser manejado com prudência se se pretender que traga proveito mais do que converta em causa de prejuízo. $\mathrm{O}$ autor examinou os principais sistemas da Europa (sistema francês, italiano, alemão, espanhol, belga e português) e os principais sistemas da América Latina (sistema argentino, uruguaio, chileno, colombiano e mexicano), na obra " $O$ Estado e a obrigação de indenizar".

${ }^{42}$ CRETELLA JÚNIOR, José. O Estado e a Obrigação de Indenizar. 2. ed. Rio de Janeiro: Forense, 2002. p. 157.

${ }^{43}$ LAZZARINI, Álvaro. Estudos de Direito Administrativo. 2. ed. São Paulo: Revista dos Tribunais, 1999. p. 421-423.

${ }^{44}$ Idem, Ibidem. p. 422.
} 
próprias de seu cargo, tem direito a reclamar e obter a correspondente reparação ou indenização na forma que a lei estabelece ${ }^{45}$, .

A Constituição do Japão, promulgada em 3 de novembro de 1.946, estabelece que “Todos poderão mover ação judicial pedindo reparação de conformidade com o que estipula a lei do Estado ou de uma entidade pública, desde que havido dano decorrente de ato ilegal praticado por qualquer funcionário público". O artigo 16 ainda garante que todos terão o direito de requerer de forma pacífica a reparação de dano e a remoção de funcionário público $^{46}$.

Entre os autores espanhóis que adotam a teoria objetiva, encontram-se Eduardo Garcia de Enterría e Tomas Ramon Fernandes ${ }^{47}$ que, em obra conjunta, afirmam:

La responsabilidad de la Administración tiende a cubrir, según los preceptos antes citados, toda lesión que los particulares sufran [...] siempre que sea consecuencia del funcionamiento normal o anormal de los servicios públicos $[\ldots]^{48}$ (grifos dos autores).

Otto Mayer, ${ }^{49}$ pioneiro no estudo do direito administrativo na Alemanha, partindo do princípio da equidade, desenvolveu a uma teoria própria acerca do sacrifício, segundo a qual, quando um indivíduo fosse submetido a um "sacrifício especial" em face dos demais administrados, e havendo nexo causal entre o resultado e a atividade estatal, sendo a atividade lícita ou não, se impunha ao Estado o dever de reparar o dano. $\mathrm{O}$ autor definiu como "sacrifício especial” o evento cujos prejuízos afetam o indivíduo de maneira desigual e fora de proporção.

\footnotetext{
${ }^{45}$ PEREIRA, Osny Duarte. Constituição de Cuba, como é e como funciona. Rio de Janeiro: Revan. p. 54 apud LAZZARINI, Álvaro. Estudos de Direito Administrativo. 2. ed. São Paulo: Revista dos Tribunais, 1999. p. 422.

${ }^{46}$ Fatos sobre o Japão, edição do Departamento de Informação Pública, Ministério dos Negócios estrangeiros do Japão, Code. 05202, mar/73. p. 2 apud LAZZARINI, Álvaro. Estudos de Direito Administrativo. 2. ed. São Paulo: Revista dos Tribunais, 1999. p. 423.

${ }^{47}$ ENTERRIA, Eduardo Garcia de; FERNANDEZ, Tomás Ramón. Curso de Derecho Administrativo. II. Buenos Aires: La Ley, 2006. p. 376.

${ }^{48}$ A responsabilidade da Administração deve alcançar, segundo os preceitos anteriormente citados, toda lesão que os particulares sofram sempre que sua consequência for originada do funcionamento normal ou anormal dos serviços públicos (tradução livre).

${ }^{49}$ MAYER, Otto. Derecho Admnistrativo Alémon, vol. 4. Tradução Horacio H. Heredia y Ernesto Krotoschin, Buenos Aires: Ediciones Arayú, 1954. In: ZANCANER BRUNINI, Weida. Responsabilidade extracontratual da administração pública. São Paulo: Revista dos Tribunais, 1981. p. 30.
} 
León Duguit ${ }^{50}$ entende que o fundamento da responsabilidade objetiva do Estado é a segurança nacional. De acordo com seu entendimento, sempre que houver um dano ao administrado, o Estado deve repará-lo, independentemente do fato de ter o serviço público funcionado normal ou anormalmente.

André de Laubadère ${ }^{51}$ assevera que a falta da Administração pode ser considerada sob dois aspectos: a falta individual de um agente público, identificável, e a falta anônima, na qual a identificação do agente não é possível, pois a organização é defeituosa, o serviço é irregular e muitas vezes há a atuação conjunta de vários agentes públicos. Para ele, a teoria objetiva ou do risco é aplicada somente em casos excepcionais, cujo campo de atuação fica restrito aos danos ocasionados pelos trabalhos públicos, no risco anormal de vizinhança, e na teoria das coisas e atividades perigosas.

Por muito tempo vigorou na França a teoria da irresponsabilidade, tanto que Laferrière, no clássico livro Traité de la Jurisdiction Administrative et des Recours Contentieux, de 1.896, escrevia que " o normal da soberania é impor-se a todos sem compensação". Segundo a análise de Paul Duez, distinguindo as várias fases do desenvolvimento da jurisprudência relativa à responsabilidade do Estado a primeira fase imperava a teoria da irresponsabilidade, já na segunda fase o problema é equacionado parcialmente no terreno civilista e, na terceira fase, a questão ganha terreno e se desenvolve em âmbito peculiar ao direito público ${ }^{52}$.

Segundo Georges Vedel ${ }^{53}$, os índices típicos que caracterizam a história da responsabilidade civil do Estado, na França, são três: a ampliação quase constante da responsabilidade da potestade pública; o aperfeiçoamento técnico da teoria das relações entre a Administração, seus agentes e as vítimas dos danos; e a delimitação da responsabilidade administrativa, como teoria autônoma.

\footnotetext{
${ }^{50}$ DUGUIT, Léon. Traité de Droit Constitucionnel. vol. 3. 3. ed., Paris: E. de Boccard Editeur, 1952. p. 459-537 apud BRUNINI, Weida Zancaner. Responsabilidade Extracontratual da Administração Pública. São Paulo: Revista dos Tribunais, 1981. p. 30.

${ }^{51}$ LAUBADÈRE, André de. Traité de Droit Administratif. v.I. 7. ed. Paris: Librairie Générale de Droit et de Jurisprudence, 1976 apud BRUNINI, Weida Zancaner. Responsabilidade Extracontratual da Administração Pública. São Paulo: Revista dos Tribunais, 1981.p. 28.

${ }^{52}$ CRETELLA JR., José. O Estado e a obrigação de indenizar. Rio de Janeiro: Forense. 2002. p. 160.

${ }^{53}$ VEDEL, Georges. Droit Administratif. 5. ed. Paris: Presses Universitaires de France, 1973. p. 327 apud CRETELLA JR., José. Op. cit.. p. 161.
} 
Quanto à doutrina italiana, Cretella Júnior ${ }^{54}$ destaca que os italianos acompanharam quase que paralelamente a orientação francesa. A doutrina italiana reflete as alterações políticas e sociais daquele país, tendo passado pela fase da irresponsabilidade para a fase civilística e, atualmente, tem equacionado os casos da responsabilidade civil do Estado em termos autênticos de direito público.

Paul Duez ${ }^{55}$, em seu tratado de Responsabilidade Pública, distingue três hipóteses dentre as quais se vislumbra a chamada faute de service:

\section{Les faits susceptibles de constituer la faute du service public}

Ils se révèlent chaque jour plus nombreaux dans le développement de la jurisprudence du Conseil d'Etat. On peut les grouper sous trois, chefs qui, dans une certaine mesure, correspondent aux étapes marquées par le développement chronologique de la faute du service public: $1^{\circ}$ le service a mal fonctionné (culpa in comittendo); $2^{\circ}$ le service n'a pas fonctionné ( culpa in omittendo); $3^{\circ}$ le service a fonctionné tardivement ${ }^{56}$.

A construção jurisprudencial e a doutrina francesa concederam grande contribuição para a construção do instituto da Responsabilidade do Estado, entretanto, curiosamente, ainda prevalece na França a teoria subjetiva - muito embora a teoria objetiva seja reconhecida, só é aplicada em casos excepcionais ${ }^{57}$.

Afirma Marcelo Caetano ${ }^{58}$ que, no Direito português, aderindo à teoria objetiva, mesmo que não exista a culpa, a Administração é responsável, porque sendo a atividade exercida em benefício da coletividade, é justo que esta venha a suportar os prejuízos que daí se originem. Para o autor, quem goza as vantagens de uma atividade deve arcar com o ônus dessa atividade.

\footnotetext{
${ }^{54}$ CRETELLA JR., José. O Estado e a obrigação de indenizar. Rio de Janeiro: Forense. 2002. p. 162.

${ }^{55}$ DUEZ, Paul. La Responsabilité de la Puissance Publique. Paris: Dalloz, 2012. p. 27.

${ }^{56}$ Os fatos suscetíveis de constituir a falta do serviço público
}

Se revelam cada dia mais numerosos no desenvolvimento da jurisprudência do Conselho de Estado. Eles podem ser agrupados em três hipóteses, que de certa forma correspondem às etapas marcadas pela evolução cronológica da falha do serviço público: $1^{\circ}$ - o serviço funcionou mal (culpa in comittendo); $2^{\circ}$ - o serviço não funcionou (culpa in omittendo); $3^{\circ}$ - o serviço funcionou tardiamente (tradução livre).

${ }^{57}$ BRUNINI, Weida Zancaner. Responsabilidade Extracontratual da Administração Pública. São Paulo: Revista dos Tribunais, 1981. p. 31.

${ }^{58}$ CAETANO, Marcelo. Manual de Direito Administrativo. 7. ed. Coimbra: Coimbra Editores, 1965. p. 375. 
No Direito chileno ${ }^{59}$, não existe texto de lei expresso sobre o tema, o que há são inúmeros dispositivos que preveem a possibilidade de o Estado ser responsabilizado, mas não apontam os critérios que serviriam como fundamento dessa responsabilidade. Os tribunais se apoiam nos critérios civilistas sempre que ocorre hipótese de responsabilização do Estado. O que precariamente regula a matéria é o art. 83 da Lei 8.282, denominado "Estatuto dos Funcionários da Administração Civil do Estado”.

$\mathrm{Na}$ doutrina argentina, Rafael Bielsa ${ }^{60}$ assevera que a responsabilidade da administração por atuação de seus agentes somente poderá ser exigida se houver lei, e por conseguinte deve ter fundamento jurídico próprio; a ausência de lei que estabeleça de modo expresso tem conduzido a um sistema deformado (de irresponsabilidade). A obrigação de indenizar, que a lei impõe ao Estado, é uma garantia legal e não responsabilidade em sentido próprio.

No sistema jurídico colombiano (lei, doutrina e jurisprudência), verifica-se que a responsabilidade patrimonial do Estado é resolvida com base na relação de direito público que nasce entre a Administração e os particulares, deixando-se de lado a natureza civil do direito violado. A norma ferida pode ser de índole civil ou administrativa, sem que se altere o caráter jurídico do vínculo nem a natureza da responsabilidade gerada ${ }^{61}$.

Em regra, todos os sistemas jurídicos evoluíram a partir da total irresponsabilidade, alguns ainda continuam baseados em critérios privatísticos, e outros vem avançando para os princípios publicísticos, cujo postulado é a distribuição equitativa dos ônus e encargos públicos, base informativa do direito público.

\subsubsection{A importância da jurisprudência}

Muito embora a teoria da responsabilidade objetiva do Estado tenha alcançado status de norma constitucional pelo advento da Constituição de 1.946, convém esclarecer que

\footnotetext{
${ }^{59}$ AYLWIN, Patrício. Manual de Derecho Administrativo. Santiago: ed. Jurídica de Chile, 1952. p. 269-270 apud CRETELLA JR., José. O Estado e a obrigação de indenizar. Rio de Janeiro: Forense, 2002. p. 169.

${ }^{60}$ BIELSA, Rafael. Derecho Administrativo. v. 5. 5. ed. Buenos Aires: Delpalma, 1957. p. 80-81 apud CRETELLA JR., José. O Estado e a obrigação de indenizar. Rio de Janeiro: Forense, 2002. p. 168.

${ }^{61}$ SARRIA, Eustorgio. Derecho Administrativo. 5. ed. Bogotá: Temis, 1968. p. 413 apud CRETELLA JR., José. O Estado e a obrigação de indenizar. Rio de Janeiro: Forense, 2002. p. 170.
} 
tal avanço foi resultado de votos dos Ministros do Supremo Tribunal Federal, dentre os quais se destacam o Ministro Pedro Lessa, seguido posteriormente pela brilhante atuação dos Ministros Orozimbo Nonato e Filadelpho de Azevedo.

Em 1.958, alargando os fundamentos doutrinários das suas decisões, o STF admite expressamente a responsabilidade do Estado por "falta anônima do serviço", ou seja, por funcionamento deficiente da Administração, independente de culpa de seus agentes. $\mathrm{O}$ caso se referia às depredações sofridas por vários cinemas em Araguari - Minas Gerais, em decorrência de movimentos populares, devido ao aumento dos ingressos. O STF concedeu a indenização, considerando o desaparelhamento do serviço policial. Em seu voto, o Ministro Mário Guimarães acentuou que: “O povo paga impostos para que a polícia garanta a propriedade e não é possível deixar de assegurar essa garantia por falta de aparelhamento"62 .

Ao votar os Embargos, o Ministro Ozorimbo Nonato, mantendo a decisão recorrida, ampliou seus fundamentos teóricos para demonstrar que, na sua percepção, a responsabilidade do Estado decorria do risco administrativo; quando verificada a falha da Administração, esta não conseguia provar não lhe ter sido possível evitar o movimento. Nessa toada, o STF transplantou para o direito brasileiro a teoria da faute de service, elaborada, na França, pelo Conselho de Estado ${ }^{63}$.

Apesar da predominância da teoria objetiva nos julgados dos Tribunais brasileiros, a jurisprudência do STF, ainda hoje, por vezes se mostra vacilante quanto à aplicação da responsabilidade objetiva ou subjetiva do Estado na hipótese de omissão, sendo a questão extremamente controvertida, carecendo o tema de uniformidade no seio do Supremo Tribunal Federal.

No RE no 109.615-2-RJ - $1^{\text {a }}$ Turma. Julgado de 28.05.1996, DJU, 01-agosto1996, o Ministro Celso de Mello, como relator do Recurso Extraordinário, acolheu a tese da incidência da responsabilidade objetiva pela omissão do Estado ${ }^{64}$.

\footnotetext{
${ }^{62}$ WALD, Arnoldo. Os Fundamentos da Responsabilidade Civil do Estado. In: Revista de Informação Legislativa, Brasília, ano 30, $\mathrm{n}^{\circ}$ 117, jan/mar 1993. p. 8.

${ }^{63}$ Idem, Ibidem. p. 9.

${ }^{64} \mathrm{STF}-1^{\mathrm{a}} \mathrm{T}$., RE no 109.615-2/RJ - Rel. Min. Celso de Mello, Diário da Justiça, seção I, agosto de 1996, p. 25.785, tendo declarado o Supremo Tribunal Federal que "essa concepção teórica, que informa o princípio constitucional da responsabilidade civil objetiva do Poder Público, fez emergir, da mera ocorrência de ato lesivo causado à vítima pelo Estado, o dever de indenizá-la pelo dano pessoal e/ou patrimonial sofrido, independentemente de caracterização de culpa dos agentes estatais ou de demonstração de falta do serviço público".
} 
De acordo com esse entendimento, diferentemente da responsabilidade subjetiva, cuja indenização decorre de um procedimento culposo ou doloso, a responsabilidade objetiva estaria caracterizada pela relação causal entre a atuação estatal e o dano produzido, correlacionada a uma situação de risco. Neste caso, somente a ausência do nexo causal poderia eximir o Estado de responder pela lesão ou morte produzida.

No julgamento do RE 84.072, o Relator, Ministro Cunha Peixoto, ressaltou o entendimento de que a responsabilidade civil do Estado, com fundamento na teoria objetiva, resulta da causalidade do ato e não da culpabilidade do Agente. A decisão do STF - já anteriormente citada - restou assim ementada:

Responsabilidade Civil do Estado. Ato omissivo. Detento morto por companheiro de cela. A teoria hoje dominante é a que baseia a responsabilidade do Estado, objetivamente, no mau funcionamento do serviço, independentemente da culpa do agente administrativo. Culpa provada dos agentes da administração por omissão concorrente para a consumação do evento danoso. Recurso extraordinário do Estado não conhecido" ${ }^{65}$.

Entretanto, o mesmo Supremo Tribunal Federal, no Recurso Extraordinário $\mathrm{n}^{\circ}$ 179.147-1-SP, 2 a Turma, sendo Relator o Ministro Carlos Velloso, chegou a uma conclusão absolutamente diversa, admitindo

[...] III - Tratando-se de ato omissivo do poder público, a responsabilidade civil por tal ato é subjetiva, pelo que exige o dolo ou a culpa, numa das três vertentes, negligência, imperícia ou imprudência, não sendo, entretanto, necessário individualizá-la, dado que pode ser atribuída ao serviço público, de forma genérica, a faute de service dos franceses ${ }^{66}$.

A responsabilidade civil do Estado por ato omissivo, de acordo com o texto constitucional, esteve em vias de ser focalizada pelo Supremo Tribunal Federal ao ser julgado o Recurso Extraordinário no 409.203/RS, Rel. Min. Carlos Velloso ${ }^{67}$, mas admitindo a responsabilidade objetiva pela omissão estatal.

\footnotetext{
${ }^{65}$ RE 84.072/BA, Rel. Min. Cunha Peixoto; $1^{\text {a }}$ Turma do STF, j. 19.11.1976.

${ }^{66}$ Eis o caso: "Ementa: Constitucional. Administrativo. Civil. Dano moral. Responsabilidade civil das pessoas jurídicas de direito público e das pessoas jurídicas de direito privado prestadoras de serviço público. Ato omissivo do Poder Público: Morte de presidiário por outro presidiário; responsabilidade subjetiva; culpa publicizada; Faute de service.C.F., art. $37, \S 6^{\circ}$."

${ }^{67}$ RE 409.203/RS - STF - Relator: Min. Carlos Velloso. Decisão: A Turma, por votação majoritária, conheceu e negou provimento ao recurso extraordinário, nos termos do voto do Senhor Ministro Joaquim Barbosa, vencido o Ministro-Relator, que dele conhecia e lhe dava provimento.
} 
Com efeito, em julgamento desse Recurso Extraordinário, realizado em 07 de março de 2006, o Supremo Tribunal Federal conheceu do recurso interposto pelo Estado do Rio Grande do Sul, mas negou-lhe provimento, o que leva à conclusão de que a decisão do Tribunal de Justiça do Estado do Rio Grande do Sul manteve a sentença prolatada em $1^{\circ}$ $\operatorname{grau}^{68}$.

Em decisões anteriores, o STF considerou pacífica a responsabilidade do Estado em casos de movimento multitudinário, fundamentada na inércia do Poder Público ${ }^{69}$ e na hipótese de danos decorrentes da falta de conservação de córrego, ensejando o seu transbordamento ${ }^{70}$.

Neste último julgamento ${ }^{71}$, o Excelso Pretório entendeu que o problema da responsabilidade do Estado envolvia a interpretação do mandamento constitucional, admitindo expressamente que as pessoas jurídicas de direito público deveriam indenizar os danos com base no "risco administrativo", ou seja, na "culpa anônima da Administração", correspondente à faute du service do direito francês. Acrescentou que tal responsabilidade se impunha sempre que ocorresse inércia da Administração Pública na execução ou manutenção dos serviços públicos que visam à segurança da população e dos usuários. É de suma importância, nesse sentido, o seguinte trecho do voto do eminente Ministro Relator:

\footnotetext{
${ }^{68}$ RESPONSABILIDADE CIVIL DO ESTADO. 1. Apenado em regime aberto que, durante fuga, invade residência e pratica violência contra as moradoras, uma delas sendo vítima de estupro. Falha evidente do Estado na fiscalização do cumprimento da pena pelo autor do fato, que, apesar de ter fugido em sete oportunidades, não foi sujeito à regressão de regime. Confirmação da sentença de procedência, por seus próprios fundamentos, inclusive quanto ao valor arbitrado como reparação dos danos morais. Homologação da desistência do apelo das autoras, restando prejudicado o recurso adesivo. Sentença confirmada em reexame necessário. A ementa do caso: "RESPONSABILIDADE CIVIL DO ESTADO. ART. 37, § $6^{\circ}$ DA CONSTITUIÇÃO FEDERAL. FAUTE DU SERVICE PUBLIC CARACTERIZADA. ESTUPRO COMETIDO POR PRESIDIÁRIO, FUGITIVO CONTUMAZ, NÃO SUBMETIDO À REGRESSÃO DE REGIME PRISIONAL COMO MANDA A LEI. CONFIGURAÇÃO DO NEXO DE CAUSALIDADE. RECURSO EXTRAORDINÁRIO DESPROVIDO. Impõe-se a responsabilização do Estado quando um condenado submetido a regime prisional aberto pratica, em sete ocasiões, falta grave de evasão, sem que as autoridades responsáveis pela execução da pena lhe apliquem a medida de regressão do regime prisional aplicável à espécie. Tal omissão do Estado constituiu, na espécie, o fator determinante que propiciou ao infrator a oportunidade para praticar o crime de estupro contra menor de 12 anos de idade, justamente no período em que deveria estar recolhido à prisão. Está configurado o nexo de causalidade, uma vez que se a lei de execução penal tivesse sido corretamente aplicada, o condenado dificilmente teria continuado a cumprir a pena nas mesmas condições (regime aberto), e, por conseguinte, não teria tido a oportunidade de evadir-se pela oitava vez e cometer o bárbaro crime de estupro. Recurso extraordinário desprovido" (RE 409203/RS; 2a Turma do STF; Rel. Min. Joaquim Barbosa; j. 07/03/2006).

${ }^{69}$ Embargos na Apelação Civil no ${ }^{\circ}$ 6.447-SP em julgado pelo Plenário em 10-8-66.

${ }^{70}$ Recurso Extraordinário no ${ }^{\circ} 61.387$, julgado pela $2^{\text {a }}$ Turma em 29-5-68, In FTJ 47/381.

${ }^{71}$ Recurso Extraordinário no ${ }^{\circ} 61.387$, julgado pela $2^{\mathrm{a}}$ Turma em 29-5-68, in RTJ 47/381.
} 
A verdade é que o ponto sensível da controvérsia em torno dos problemas da responsabilidade são os casos de ação ou "falta de providências indispensáveis ao bom funcionamento do serviço". É o que se chamou de inércia da administração na execução de serviços públicos que visam à segurança da população e dos usuários.

Com essas decisões, o STF transplantou para o Direito Brasileiro a teoria da faute du service, elaborada na França, pelo Conselho de Estado. A culpa do serviço se caracteriza pela ineficácia, pelo mau funcionamento ou pelo funcionamento tardio da Administração, que ensejam a responsabilidade. Em tais casos, não há motivo para examinar a culpa do agente, bastando que se reconheça a deficiência do funcionamento do serviço público, caracterizando a chamada "culpa ou falta anônima".

Como se vê, essa posição do STF é contrária ao posicionamento sustentado por Celso Antônio Bandeira de Mello, que entende que nessa hipótese a responsabilidade estatal é subjetiva, e não objetiva, quando afirma este autor que a

responsabilidade por 'falta de serviço', falha do serviço ou culpa do serviço (faute $d u$ service, seja qual for a tradução que se lhe dê) não é, de modo algum, modalidade de responsabilidade objetiva, ao contrário do que entre nós e alhures, às vezes, tem-se inadvertidamente suposto. É responsabilidade subjetiva porque baseada na culpa (ou dolo), como sempre advertiu o Prof. Oswaldo Aranha Bandeira de Mello ${ }^{72}$.

Não comungamos, nesse particular, com este último posicionamento, visto que o artigo 37, § 6 $6^{\circ}$, da Constituição Federal de 1.988 não faz nenhuma distinção entre atos omissivos ou comissivos, recepcionando a responsabilidade objetiva estatal.

Assim, em recentíssimo julgamento do Recurso Extraordinário no 272.839-MT tratava-se de caso de morte de detento -, o relator, Ministro Gilmar Mendes, a despeito da já tradicional opinião lançada pelo ex-Ministro Carlos Velloso (responsabilidade subjetiva fundada na faute de service), tocou novamente a questão, enfocando-a sob prisma diverso:

1. RECURSO EXTRAORDINÁRIO. 2. MORTE DE DETENTO POR COLEGAS DE CARCERAGEM. INDENIZAÇÃO POR DANOS MORAIS E MATERIAIS. 3. DETENTO SOB A CUSTÓDIA DO ESTADO. RESPONSABILIDADE OBJETIVA. 4. TEORIA DO RISCO ADMINISTRATIVO. Configuração do nexo de causalidade em função do dever constitucional de guarda (art. $5^{\circ}$, XLIX). Responsabilidade de reparar o dano que prevalece ainda que demonstrada a ausência de culpa dos agentes públicos. 5. Recurso extraordinário a que se nega provimento. [...] A partir dos precedentes desta Corte, portanto, observa-se que uma das hipóteses do reconhecimento da responsabilidade do Estado consubstancia-se no dever de

\footnotetext{
${ }^{72}$ MELLO, Celso Antônio Bandeira de Curso de Direito Administrativo. 28. ed. revisada, atualizada e ampliada. São Paulo: Malheiros, 2011. p.1024.
} 
vigilância que lhe é atribuído. Assim, apesar do fundamento que considera a configuração de uma espécie de culpa genérica da Administração (faute du service), destaco o argumento jurídico de que, no caso concreto sob análise, a responsabilidade advinda do dever de vigilância ou guarda pode ser objetivamente imputada ao aparato estatal. Na espécie o detento estava em cumprimento de pena privativa de liberdade, portanto, sob custódia do Estado. Trata-se, portanto, da hipótese em que o nexo de causalidade que imputa a responsabilidade do Poder Público advém do dever constitucional de guarda, consagrado no art. $5^{\circ}$, XLIX (é assegurado aos presos o respeito à integridade física e moral). Neste caso, ainda que demonstrada a ausência de culpa dos agentes públicos, prevalece a responsabilidade do Estado pela reparação do dano ${ }^{73}$.

O precedente é importante, segundo Luciano Ferraz,

[...] porquanto liga a responsabilidade do Estado por omissão não à culpa dos agentes ou dos serviços (faute de service), senão ao dever constitucionalmente assentado de garantir a integridade física do preso. É dizer: o que interessa para gerar a obrigação de indenizar é o descumprimento do dever (objetivo) de atuação em face do que determina o ordenamento jurídico.

Deveras, ainda que se admita a dificuldade de apontar comportamentos omissivos que não sejam acompanhados de culpa, é preciso perceber que, para fins de configuração da responsabilidade do Estado, este elemento é o mais das vezes prescindível. Tudo se resolverá na questão do ônus da prova: competirá ao Estado, nos casos de omissão, comprovar hipóteses excludentes de responsabilidade, que provocarão a ruptura do nexo de causalidade, eximindo-o da responsabilidade ${ }^{74}$.

Nesse caso, trata-se de recurso extraordinário interposto com fundamento no permissivo constitucional do art. 102, III, “a”, da Constituição Federal, contra acórdão do Tribunal de Justiça do Estado de Mato Grosso que condenou o Estado à indenização por danos morais e materiais por morte de detento por seus colegas de carceragem dentro da Penitenciária Estadual.

O Tribunal de Justiça do Estado de Mato Grosso negou provimento ao recurso do Estado, de acordo com os seguintes fundamentos:

RESPONSABILIDADE CIVIL DO ESTADO - MORTE DE DETENTO RESPONSABILIDADE OBJETIVA - REPARAÇÃO POR DANOS MORAIS E PATRIMONIAIS DEVIDA - RECURSO PROVIDO. O ordenamento constitucional vigente assegura ao preso a integridade física (CF. art. $5^{\circ} \mathrm{XLIX}$ ) sendo dever do Estado garantir a vida de seus detentos, mantendo, para isso, vigilância constante e eficiente. Assassinado o preso

\footnotetext{
${ }^{73}$ RE 272839/MT; Rel. Min. Gilmar Mendes, da $2^{\mathrm{a}}$ Tuma, do STF; j. 01.02.2005.

${ }^{74}$ FERRAZ, Luciano. Responsabilidade do Estado por omissão legislativa - caso do art. 37, X da Constituição da República. In: FREITAS, Juarez (org.). Responsabilidade civil do Estado. São Paulo: Malheiros, 2006, p. 215-217.
} 
quando cumpria pena por homicídio qualificado, responde o Estado civilmente pelo evento danoso, independentemente da culpa do agente público $^{75}$.

Acrescente-se que, nessa hipótese, não se trata de responsabilizar o Estado por um dever abstrato de atuação - porque o Estado não é um segurador universal -, mas de responsabilizá-lo quando tenha ele o dever concreto de atuação.

Conclui-se, pois, que a ausência de medidas para garantir o bom funcionamento dos serviços e impedir eventuais danos a particulares enseja uma responsabilidade, que é presumida até que a Administração possa fazer prova de ter ocorrido, no caso, força maior.

Em suma, podemos sintetizar que a jurisprudência do STF, ao adotar a teoria da culpa de serviço, firmou os seguintes princípios:

a) quando o Estado causa algum dano, por ação ou omissão, deve o mesmo dano ser reparado, independentemente da prova da culpa;

b) a relação de causalidade decorre do simples fato de ter ocorrido o dano ou haver sido ensejada a sua ocorrência em virtude de ação ou de inércia dos Poderes Públicos;

c) a pessoa jurídica de direito público só se exonera da responsabilidade comprovando a força maior, não bastando a prova de simples ausência de culpa dos funcionários, como entendia a jurisprudência anterior;

d) ao autor da ação cabe provar os fatos e não a culpa, que se presume pela simples razão de os fatos evidenciarem, no caso, o funcionamento deficiente ou a ausência de funcionamento adequado do serviço público.

A posição do STF tem sido acompanhada pelos demais tribunais do País. Assim, o Tribunal de Justiça de São Paulo teve o ensejo de manifestar-se nos acórdãos com as seguintes ementas:

Responde o Estado pelos danos causados à propriedade privada quando não toma providências adequadas para coibir a exaltação popular e as depredações dela consequentes (TJSP $-3^{\text {a }}$ Câmara - Ap. Rel. Cardoso Rolim - j. 14.6.56 - RDA 49/198).

A responsabilidade da Administração pelos danos causados por obra pública independe de prova de culpa, bastando a existência do nexo causal ${ }^{76}$.

A responsabilidade civil do Poder público, perante os particulares, por inundações ocorridas pelo mau funcionamento dos serviços públicos é

\footnotetext{
${ }^{75}$ RE 272839/MT; Rel. Min. Gilmar Mendes, da $2^{\text {a }}$ Tuma, do STF; j. 01.02.2005; v.u.

${ }^{76}$ Apelação Cível no 140.926 ,in RDA, 87/221.
} 
integral e não parcial, ainda que outros fatores atribuíveis a terceiros, ou a caso fortuito, concorram para o evento danoso ${ }^{77}$.

Danos resultantes de enchentes ocasionados por forte chuva. Deficiência na execução de obras e serviços pela Municipalidade demonstrada ${ }^{78}$.

Danos resultantes de enchentes do rio Tietê. Art. 107 da CF. Falta de serviço de controle. Fato que provocou prejuízos às lavouras de proprietários rurais $^{79}$.

Danos causados em estabelecimento comercial, por deficiente escoamento de águas pluviais, durante forte chuva ${ }^{80}$.

A Municipalidade responde por prejuízos a estabelecimento industrial decorrentes da má conservação de bueiros e galerias de águas pluviais e da omissão de obras indispensáveis de limpeza e regularização das margens e do leito de rio ${ }^{81}$.

A Municipalidade responde por danos causados por enchentes a imóvel, se decorrentes de mau funcionamento do serviço, a que se obrigou ${ }^{82}$.

Danos causados em residência, por deficiente escoamento de águas pluviais, agravados por depósito de terra deixada pela Prefeitura, concorrendo para os entupimentos ${ }^{83}$.

A Municipalidade responde por danos causados a residência por enchente resultante não de chuvas anormais e imprevisíveis, mas de deficiência do serviço público ${ }^{84}$.

Enchente do rio Tamanduateí, na Capital, que causa dano a particulares. Responsabilidade da Prefeitura Municipal de São Paulo decorrente da culpa administrativa ou culpa anônima do serviço ${ }^{85}$.

\footnotetext{
${ }^{77}$ Recurso de Revista n ${ }^{\circ} 175.975$, in $R D A, 12 / 214$.

${ }^{78} 2^{\mathrm{a}}$ Câmara Cível do TJSP, 7-11-80, RJTJSP, 69/103.

${ }^{79} 5^{\text {a }}$ Câmara Cível do TJSP, 13-12-79, RJTJSP, 62/92.

${ }^{80} 6^{\mathrm{a}}$ Câmara Cível do TJSP, 21-6-79, RJTJSP, 62/96.

${ }^{81} 2^{\mathrm{a}}$ Câmara Cível do TJSP, 5-12-78, RT, 528/74.

${ }^{82} 5^{\text {a }}$ Câmara Cível do TJSP, 5-4-79, RT, 530/70.

${ }^{83} 3^{\text {a }}$ Câmara Cível do TJSP, 26-5-77, RJTJSP, 47/125.

${ }^{84} 5^{\text {a }}$ Câmara Cível do TJSP, 14-5-76, RT 511/116.

${ }^{85}$ TJSP, RJTJSP, 17/173. No mesmo sentido: "INDENIZAÇÃO - RESPONSABILIDADE CIVIL CONTRATO DE DEPÓSITO - MERCADORIA ATINGIDA POR ÁGUA DE ENCHENTE - Ocorrência de fato de terceiro e caso fortuito que não se aplicam à hipótese - Enchentes com inundação que surgem com frequência na região em que estavam as mercadorias depositadas - Culpa "in custodiendo" caracterizada Omissão de obras que protejam das inundações que, por outro lado, estende a responsabilidade pelo dano a municipalidade - Indenização devida solidariamente pela Municipalidade e empresa - Recurso provido". (AC 128.499-1, TJSP, Rel. Des. Ernani de Paiva, j. 11.10.91);
} 
Sendo a causa de sucessivos transbordamentos da corrente a diminuta profundidade de seu canal, aliada ao acúmulo de galhos e detritos carregado pelas águas, caracterizada esta a falha do serviço administrativo devendo a Municipalidade arcar com os prejuízos causados pelas inundações ${ }^{86}$.

Por sua vez, o antigo Tribunal de Justiça do Estado da Guanabara tem admitido a responsabilidade objetiva do Estado por atos de pilhagem que a polícia não impediu ${ }^{87}$.

E, também, a consagrou em caso de tiroteio entre a polícia e bandidos, no qual faleceu terceiro, conforme se verifica no acórdão da $5^{\text {a }}$ Câmara do TJERJ, na AC no 2.711/86, de 30-09-86, no qual ficou decidido que:

Com base na teoria do risco administrativo, o Estado é responsável pela morte de pessoa ocorrida em razão de tiroteio iniciado por policiais contra bandidos. Quanto ao mérito, a espécie é de ação contra o Estado, pretendendo a autora indenização pela morte da mãe, ocorrida em virtude de disparos de uma arma de fogo feitos em diligência policial na captura de marginais. Invocando o art. 107 da Constituição Federal a Dra. Juíza julgou procedente o pedido. Apela o Estado, insurgindo-se contra o reconhecimento de sua responsabilidade, sob a assertiva de que, havendo dúvida quanto à autoria dos disparos que atingiram a mãe da autora, a ação deveria ser julgada improcedente. Sem razão, contudo, o apelo. A espécie aplica-se à teoria do risco administrativo segundo a qual a obrigação de reparar o dano decorre do ato lesivo e injusto causado à vítima em decorrência da diligência policial. Como se sabe, na teoria do risco administrativo exige-se apenas o

"INDENIZAÇÃO - RESPONSABILIDADE OBJETIVA DO ESTADO - FAZENDA PÚBLICA ENCHENTES - DANOS CAUSADOS A IMÓVEIS LOCALIZADOS EM VIAS PÚBLICAS, INVADIDOS

PELAS ÁGUAS - responsabilidade da municipalidade que deflui de sua ineficiência administrativa - força maior não demonstrada - nexo causal caracterizado - verba devida - recurso provido para julgar procedente a demanda". (AC 153.680-1, TJSP, Rel. Des. Marcus Andrade, j. 21.11.1991); "RESPONSABILIDADE CIVIL DO ESTADO - Enchentes -- Transbordamento de córrego - Insuficiência da seção de vazão - Obras de canalização não concluídas - Demora - Ineficiência da administração municipal - Indenização apurada em perícia - Obrigatoriedade do ressarcimento com base nesta - Ação julgada improcedente - Decisão reformada". ((TJSP) RT 690/61);

"RESPONSABILIDADE CIVIL DO ESTADO - TRANSBORDAMENTO DE RIBEIRÃO - Município de Diadema - Morte do filho dos autores por leptospirose - Sucessivas enchentes ocorridas no local - Alegação de culpa administrativa, em razão da omissão da municipalidade, que não teria tomado providências para a limpeza e desassoreamento do Ribeirão dos Coutos - Necessidade da comprovação da culpa ou falha do serviço, que não funcionou, funcionou mal ou funciona atrasado - Alegação da ré de que a própria população joga detritos no curso d'água, dificultando a coleta de lixo e falta de relação da enchente com a doença contraída pela vítima - Culpa administrativa admitida, excepcionalmente, em face da afirmação não negada pela Administração, da ocorrência recorrente de enchentes e da falta de limpeza do referido córrego, que contribui para a proliferação de doenças - Indenizatória parcialmente procedente fixada a pensão mensal, em $2 / 3$ do salário mínimo porque desempregada a vítima, com o termo final da remuneração até a data em que esta completaria vinte e sete (27) anos de idade - Reexame necessário e recurso voluntário da municipalidade desprovidos quanto ao tema". (Apelação n. 237.841-5/0 - Diadema - $10^{a}$ Câmara de Direito Público - Relator: Torres de Carvalho - 24/07/06 - VU - voto n. 90/06).

${ }^{86}$ A.C. ${ }^{\circ} 61.979-1$, TJSP, in: $R T$ 605/58.

${ }^{87}$ Apelação civil no 40.928 , in Revista de jurisprudência do TJGB 14/175. 
fato do serviço. Não se cogita de culpa da Administração ou de seus agentes. Basta que se demonstre o fato danoso em virtude de ação do Poder Público. E isso foi feito. Para se eximir da responsabilidade, o Estado deveria comprovar culpa exclusiva da vítima ou a ocorrência de caso fortuito ou de força maior. Nesse sentido, porém, nada diligenciou o recorrente, não havendo, assim, por que exonerá-lo de responsabilidade ${ }^{88}$.

O Tribunal de Justiça de Minas Gerais também vem se inclinando pelo reconhecimento da teoria objetiva:

INDENIZAÇÃO - ACIDENTE DE TRÂNSITO - SINISTRO OCASIONADO PELA FALTA DE SERVIÇO NA CONSERVAÇÃO DE ESTRADA - AUSÊNCIA DE PROVA DE CULPA DO PARTICULAR,

\footnotetext{
${ }^{88}$ Nesse sentido: "INDENIZAÇÃO - RESPONSABILIDADE CIVIL DO ESTADO - CARACTERIZAÇÃO DISPARO DE ARMA DE FOGO POR POLICIAL MILITAR ATINGINDO E CAUSANDO INCAPACIDADE TOTAL E PERMANENTE NA VÍTIMA - Responsabilidade de caráter objetivo e não subjetivo - Inteligência do artigo 37, § $6^{\circ}$ da Constituição da República 1988 - Pedido procedente - Recurso provido para esse fim”. (Relator: Álvaro Lazzarini - Apelação Cível 132.653-1 - 12.03.91 - São Paulo);

"INDENIZAÇÃO - RESPONSABILIDADE CIVIL DO ESTADO - DISPARO DE ARMA DE FOGO POR POLICIAL NO EXERCÍCIO DA FUNÇÃO - Inexistência de provas de revide por parte da vítima à ação policial ou mesmo de que tenha realizado algum ilícito penal - Caracterização de excesso - Inocorrência de caso fortuito - Responsabilidade objetiva da Fazenda - Verba devida - Recurso parcialmente provido. A vítima teve violado seu direito à segurança sendo que o Estado tem o dever de assegurar a paz. O Estado, no caso, só se exime da responsabilidade se lograsse provar a culpa da vítima ou a ocorrência de caso fortuito". (Relator: Leite Cintra - Apelação Cível n. 192.765-1 - São Paulo - 23.06.93);
}

"INDENIZAÇÃO - FAZENDA PÚBLICA - RESPONSABILIDADE CIVIL - AÇÃO DE POLICIAL MILITAR DE FOLGA E À PAISANA - Morte de transeunte provocada por disparo de arma de fogo da Corporação, quando detia meliante - Verba devida pelo Estado - Artigos 37, § $6^{\circ}$, da Constituição da República, e 159 do Código Civil - Sentença confirmada”. (STJ 202/103);

"RESPONSABILIDADE CIVIL DO ESTADO - ATO ILÍCITO DE PREPOSTO - DANO CAUSADO POR DISPARO DE ARMA DE FOGO DE POLICIAL EM TUMULTO PÚBLICO - Ação de indenização Desnecessidade de identificação do agente na inicial - Denunciação da lide não obrigatória na espécie - Tarefa, ademais, que competiria ao próprio ente público - Suficiência da certeza de ser a bala proveniente de arma utilizada pela Polícia Militar - Responsabilidade de natureza objetiva e irretratável, diante da adoção da teoria do risco administrativo. Inépcia da petição inicial afastada”. (RT 641/139 (TJSP));

"INDENIZAÇÃO - RESPONSABILIDADE CIVIL DO ESTADO - LESÃO CORPORAL - DANO MORAL E DANO MATERIAL - TIROS DISPARADOS POR POLICIAL MILITAR EM PERSEGUIÇÃO À VÍTIMA POR CAUSA DE INFRAÇÃO DE TRÂNSITO - Diligência mal sucedida - Excesso culposo - Indevido manuseio e disparo da arma - Responsabilidade da Fazenda e do policial - Mal funcionamento do serviço público - Perseguição que apenas deveria redundar na detenção da vítima - Ausência de excludente e de perigo para o agente - Falta de culpa exclusiva da vítima - Falta de prova de danos materiais - Dano moral estabelecido, consideradas as circunstâncias e a situação econômica dos envolvidos - Recurso parcialmente provido para redução do montante do dano moral, mantida a sucumbência da sentença". (Apelação Cível n. 8.098-5 - São José dos Campos - $1^{\text {a } ~ C a ̂ m a r a ~ d e ~ D i r e i t o ~ P u ́ b l i c o ~-~ R e l a t o r: ~ C a u d u r o ~ P a d i n ~-~ 10.03 .98 ~-~ V . U .) ; ~}$

"EMENTA: AGRAVO REGIMENTAL EM RECURSO EXTRAORDINÁRIO. CONSTITUCIONAL. ADMINISTRATIVO. TIROTEIO ENTRE POLICIAIS E BANDIDOS. MORTE DE TRANSEUNTE. RESPONSABILIDADE CIVIL DO ESTADO. NEXO DE CAUSALIDADE. REEXAME. IMPOSSIBILIDADE. Tiroteio entre policiais e bandidos. Precauções necessárias a evitar-se risco à incolumidade pública. Inexistência. Morte de transeunte. Responsabilidade civil do Estado pelos danos que seus agentes causarem nessa condição. Nexo de causalidade constatado nas instâncias ordinárias. Reexame. Impossibilidade. Súmula 279/STF. Agravo regimental não provido. (RE-AgR 257090/RJ; Rel. Min. Maurício Corrêa, Segunda Turma do STF, j. 18.04.2000). 
BEM COMO DE EVENTO TIPIFICADOR DE FORÇA MAIOR COMPROVAÇÃO DO NEXO DE CAUSALIDADE ENTRE A LESÃO E O ATO DA ADMINISTRAÇÃO - Verba devida - Aplicação da teoria do risco administrativo, nos termos do art. $37, \S 6^{\circ}$, da CF (TJMG, RT 777/365).

No sentido de reconhecer a responsabilidade pela omissão estatal, o Tribunal de Justiça do Rio de Janeiro exarou as seguintes decisões:

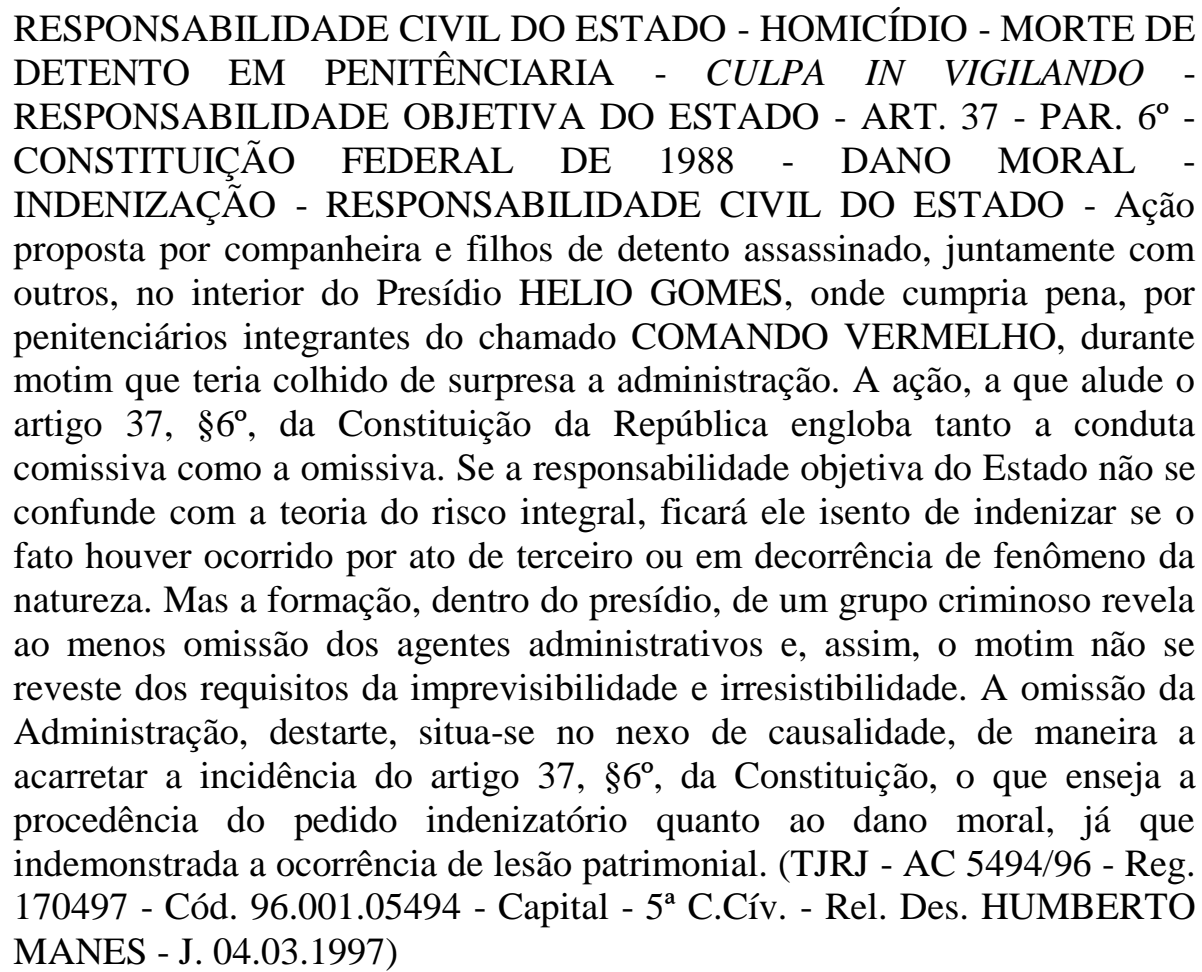

RESPONSABILIDADE CIVIL DO ESTADO - MÁ EXECUÇÃO DOS SERVIÇOS PÚBLICOS - RISCO ADMINISTRATIVO - DANO E NEXO DE CAUSALIDADE. A responsabilidade civil das pessoas jurídicas de direito público, responsabilidade objetiva, com base no risco administrativo, que admite pesquisa em torno da culpa do particular, para o fim de abrandar ou mesmo excluir a responsabilidade estatal, ocorre, em síntese, diante dos seguintes requisitos: a) do dano; b) da ação administrativa (comissiva ou omissiva); c) do nexo causal entre o dano e a ação administrativa. - O Município tem, por obrigação, manter em condições de regular uso e sem oferecer riscos, as vias públicas e logradouros abertos à comunidade (TJ RJ - Ap. 7613/94 - 6 a C.Civ. - Rel. Dês. Pedro Ligiéro - apud COAD 75286).

O Tribunal de Justiça do Rio Grande do Sul já se posicionou frente a essa questão, sem dificuldades, conforme se depreende do referido julgado transcrito: 
HPS QUANDO DO ATENDIMENTO POSTERIOR AO DELITO. CONSOLIDAÇÃO DE DEFORMIDADE NO BRAÇO DIREITO QUE RESTOU COM SEQUELA IRREVERSÍVEL E CAUSADORA DE INCAPACIDADE FUNCIONAL PERMANENTE DO MEMBRO AFETADO. RESPONSABILIDADE CIVIL OBJETIVA POR OMISSÃO DO ENTE PÚBLICO. DANOS EXTRAPATRIMONIAIS VERIFICADOS. RESPONSABILIDADE DO ESTADO OMISSÃO - Tratando de responsabilidade civil do estado por omissão, aplica-se a teoria da responsabilidade civil objetiva, segundo a qual deve o cidadão comprovar a omissão, o dano e o nexo causal. A omissão capaz de gerar o dever de indenizar está relacionada com o descumprimento de um dever jurídico de agir. Exigibilidade de conduta, examinada a partir do princípio da proporcionalidade e das situações do caso concreto. Para que obtenha êxito na sua ação indenizatória, ao autor impõe-se juntar aos autos elementos que comprovem a presença de tais elementos caracterizadores da responsabilidade civil aplicável ao caso em exame. Configurada hipótese de responsabilidade extracontratual do Estado pelo evento danoso, porquanto devidamente comprovado nos autos, bem como o nexo de causalidade com a atuação omissiva do ente público demandado. Caso em que configurada a ilicitude no agir do demandado, uma vez que não realizou cirurgia no autor enquanto preso, indicada por médico do HPS. Houve, assim, a consolidação de deformidade no braço direito do segregado, que restou com sequela irreversível causador de incapacidade funcional permanente do membro afetado. Descumprimento do disposto no art. 10, da Lei $\mathrm{n}^{\mathrm{o}} 7.210 / 84$. Configurado, pois, o ato ilícito, em razão de conduta omissiva do ente público estadual. - DANOS EXTRAPATRIMONIAIS - A configuração do dano extrapatrimonial, na hipótese, é evidente e inerente à própria ofensa, pois o abalo suportado pelo autor afeta atributo importante dos direitos de personalidade, consubstanciado na violação ao direito subjetivo de tratamento médico adequado enquanto segregado do sistema prisional, caracterizando dano extrapatrimonial. (Apelação Cível No 70046589206, Nona Câmara Cível, Tribunal de Justiça do RS, Relator: Leonel Pires Ohlweiler, Julgado em 27/06/2012).

Pode-se, assim, afirmar com segurança que, na seara da responsabilidade do Estado por omissão, a jurisprudência pátria tem interpretado e firmando posição cada vez mais segura no sentido de que a atividade administrativa a que alude o art. $37, \S 6^{\circ}$, da Constituição Federal abrange tanto a conduta comissiva quanto a omissiva, dispensando a verificação de culpa da Administração, uma vez que não é necessário provar, diante das circunstâncias do caso concreto, se houve culpa ou dolo, bastando apenas a identificação de nexo de causalidade entre o dano e a atividade estatal. 


\subsection{RESPONSABILIDADE POR OMISSÃO LEGISLATIVA}

No que se refere à responsabilidade por atos legislativos, há quem advogue em favor da tese da irresponsabilidade com base nos seguintes fundamentos ${ }^{89}$ : em primeiro lugar, pelo fato de que o Poder Legislativo detém soberania na edição de leis. Em segundo lugar, afirma-se que não tem cabimento a indenização porque a lei típica é geral e abstrata, afetando, assim, de maneira equânime e indistinta, todos os membros da Sociedade. Por derradeiro, argumenta-se que não é possível exigir do Estado reparação porque as leis foram elaboradas por parlamentares eleitos pela população. Todas essas justificativas talvez sejam decorrentes do fato de, no Brasil, não haver previsão legal a respeito do tema ${ }^{90}$.

Tais argumentos não merecem prosperar, porque não é auspicioso defender que, no estágio atual de Democracia, o Poder Legislativo seja soberano, pois a soberania é atributo do Estado, que como se sustenta ao longo desta dissertação, pode ser responsabilizado com fulcro no artigo $37, \S 6^{\circ}$, da Constituição Federal vigente. Além disso, é possível que a lei em sentido formal tenha efeitos singulares e concretos, profundamente díspares, onerando, de maneira desproporcional, alguns indivíduos. Por fim, é inaceitável alegar que o prejuízo suportado pelo cidadão não seja indenizável, apenas pelo fato de esse mesmo cidadão ter elegido, ainda que indiretamente, o legislador que elaborou a lei que o prejudicou.

Jean Rivero $^{91}$, referindo-se à responsabilidade do Estado por atos do Poder Legislativo, realça que é necessário fazer-se uma distinção entre os danos imputáveis à atividade dos serviços do Parlamento e os danos causados pelas leis e observa que, na França, “O decreto 58-1.100, invertendo as soluções anteriores, estabelece, no seu art. $8^{\circ}$, o princípio de responsabilidade do Estado relativa a danos de qualquer natureza causados pelos serviços das assembleias parlamentares".

Acerca desse tema, Mônica Nicida Garcia esclarece que ${ }^{92}$ :

Quanto aos atos legislativos, excluam-se, inicialmente, de qualquer dúvida, quanto à incidência da responsabilidade, aqueles de efeitos concretos, e que são verdadeiros atos administrativos. É certa a sujeição destes à disciplina

\footnotetext{
${ }^{89}$ DI PIETRO, Maria Sylvia Zanella. Direito Administrativo. 24. ed. São Paulo: Atlas, 2011. p.657-658.

${ }^{90}$ LAZZARINI, Álvaro. Estudos de Direito Administrativo. 2. ed. São Paulo: Revista dos Tribunais, 1999. p. 439.

${ }^{91}$ RIVERO, Jean. Direito Administrativo. Tradução Rogério Ehrhardt Soares. Coimbra: Almedina, 1981. p. 339 apud LAZZARINI, Álvaro. Estudos de Direito Administrativo. 2. ed. São Paulo: Revista dos Tribunais, 1999. p. 439.

92 GARCIA, Mônica Nicida. Responsabilidade do Agente Público. 2. ed. Belo Horizonte: Fórum, 2007. p. 197.
} 
geral de responsabilidade estatal. Quanto às leis, propriamente ditas, a matéria não é pacífica.

O Ato legislativo é ato normativo decorrente de processo legislativo que tem o condão de inovar a ordem jurídica, criando direitos, obrigações, faculdades, deveres ou poderes, por meio de normas jurídicas que não estavam presentes no ordenamento jurídico positivo $^{93}$.

Observe-se, ainda, que o ato legislativo é decorrente do exercício de uma competência outorgada pela vontade do povo a um grupo de agentes públicos, com a finalidade de garantir a segurança jurídica e a persecução dos objetivos da República esculpidos no artigo $3^{\circ}$ da Carta Magna:

Art. $3^{\circ}$ - Constituem objetivos fundamentais da República Federativa do Brasil: I - construir uma sociedade livre, justa e solidária; II - garantir o desenvolvimento nacional; III - erradicar a pobreza e a marginalização e reduzir as desigualdades sociais e regionais; IV - promover o bem de todos, sem preconceitos de origem, raça, sexo, cor, idade e quaisquer outras formas de discriminação.

O processo legislativo é o procedimento que se configura em uma sequência concatenada de atos jurídicos, que superados produzem uma lei. A principal distinção entre processo legislativo e matéria legislada se mostra pela definição dos dois institutos, um é produto do outro, a lei é produto do processo legislativo.

João Sento Sé $^{94}$ entende que a responsabilidade civil do Estado, desde que presentes os seus pressupostos, não enseja dúvidas quanto aos danos provocados pelos agentes do Poder Executivo. Entretanto, o mesmo não acontece quanto à responsabilidade resultante de prejuízos causados pelos agentes do Legislativo e do Judiciário. É tradicional o princípio da irresponsabilidade do Estado-Legislador. Mas a jurisprudência de alguns países tem admitido a responsabilidade por danos oriundos da lei. Na França, ainda que em hipóteses excepcionais, o Conselho de Estado já a tem acolhido, assim como acontece no Uruguai, que também tem aceitado tal hipótese, inclusive pela Suprema Corte de Justiça.

No que tange às atividades estatais suscetíveis de resultarem em compromisso estatal de reparação de danos, seu marco superiormente avançado é a responsabilidade por atos legislativos, o que já sucede em tempos hodiernos ${ }^{95}$.

\footnotetext{
${ }^{93}$ ZOCKUN, Maurício. Responsabilidade Patrimonial do Estado. São Paulo: Malheiros, 2010. p. 73.

${ }^{94}$ SÉ, João Sento. Responsabilidade civil do Estado por atos judiciais. São Paulo: Bushatsky, 1976. p. 99.

95 BANDEIRA DE MELlo, Celso Antônio. Curso de Direito Administrativo. 28. ed. São Paulo: Malheiros, 2010. p. 1006.
} 
Mauricio Zockun ${ }^{96}$, aderindo ao posicionamento de Diógenes Gasparini e Amaro Cavalcanti, defende que “[...] se o ato oriundo do exercício da função legislativa faz eclodir um dano ilícito a direito subjetivo ou a interesse jurídica e economicamente mensurável, tal circunstância faz nascer a responsabilidade patrimonial do Estado" .

que $^{97}$ :

Alexandre Rezende da Silva, socorrendo-se do movimento iluminista, revela

Rousseau entende que a lei é a expressão máxima, a manifestação por excelência do vínculo social, a mais alta forma reguladora da ordem social. É o reflexo terreno de uma sabedoria transcendente, deriva da moralidade antes de derivar do poder. O problema está em conseguir, na política, estabelecer um governo que coloque a lei acima do homem. A dificuldade é tanta que o filósofo compara esse problema ao da quadratura do círculo em geometria. Por isso mesmo o governo que, por sua natureza, se mantém o mais próximo da lei é o melhor, no pensamento do genebrino.

A omissão legislativa causa dano indenizável, uma vez que, partindo do pressuposto de que a lei proporciona ao cidadão a fruição de certos direitos ou, ainda, impõe o dever de praticar determinadas condutas, e levando-se em conta que o nascimento dessa mesma lei depende, exclusivamente, do exercício concreto da competência legislativa a cargo do Poder legitimamente constituído, facilmente se deduz que a ausência de lei material seja a causa motivadora da conduta ilícita.

Esse é o entendimento esposado por Maurício Zockun ${ }^{98}$ e, segundo ele, compartilhado por Celso Antônio Bandeira de Mello, Almiro do Couto e Silva, Jorge Luis Salomoni, entre tantos outros, conforme se vê:

[..] caso o poder constituído seja omisso no seu dever de legislar e, com isso, frustre a legítima expectativa dos membros da sociedade ao gozo de uma situação jurídica prescrita na Constituição, restará configurada a prática de uma conduta ilícita.

Uma das hipóteses é a indenização da lesão causada por omissão legislativa, notadamente no que se refere à edição de leis que tenham por objetivo dar operacionalidade às regras contidas na Magna Carta.

\footnotetext{
${ }^{96}$ ZOCKUN, Maurício. Responsabilidade Patrimonial do Estado. São Paulo: Malheiros, 2010. p. 120, nota 152.

${ }^{97}$ SILVA, Alexandre Rezende da. Princípio da legalidade. In: Jus Navigandi, Teresina, ano 8, n. 63, 1 mar. 2003 . Disponível em: 〈http://jus.com.br/revista/texto/3816>. Acesso em: 18 jul. 2012.
}

${ }^{98}$ ZOCKUN, Maurício. Responsabilidade Patrimonial do Estado. São Paulo: Malheiros, 2010. p. 162, nota 288. 
O STF já se posicionou no sentido de que a omissão legislativa pode acarretar a responsabilidade patrimonial do Estado, nos casos em que houve fixação de prazo para que o direito garantido constitucionalmente fosse regulamentado pelo Congresso Nacional ${ }^{99}$.

O Tribunal, por unanimidade, julgou procedente pedido formulado em ação direta de inconstitucionalidade por omissão, ajuizada pela Assembleia Legislativa do Estado de Mato Grosso, para reconhecer a mora do Congresso Nacional em elaborar a lei complementar federal a que se refere o $\S 4^{\circ}$ do art. 18 da CF, na redação dada pela EC 15/1996 ("A criação, a incorporação, a fusão e o desmembramento de Municípios, far-se-ão por lei estadual, dentro do período determinado por Lei Complementar Federal, e dependerão de consulta prévia, mediante plebiscito, às populações dos Municípios envolvidos, após divulgação dos Estudos de Viabilidade Municipal, apresentados e publicados na forma da lei”), e, por maioria, estabeleceu o prazo de 18 meses para que este adote todas as providências legislativas ao cumprimento da referida norma constitucional. (ADI 3682/MT, rel. Min. Gilmar Mendes, 9.5.2007) ${ }^{100}$.

E, ainda,

\section{DIREITO DE GREVE.}

O Tribunal julgou três mandados de injunção impetrados, respectivamente, pelo Sindicato dos Servidores da Polícia Civil no Estado do Espírito Santo SINDIPOL, pelo Sindicato dos Trabalhadores em Educação do Município de João Pessoa - SINTEM, e pelo Sindicato dos Trabalhadores do Poder Judiciário do Estado do Pará - SINJEP, em que se pretendia fosse garantido aos seus associados o exercício do direito de greve previsto no art. 37, VII, da CF ("Art. 37. [...] VII - o direito de greve será exercido nos termos e nos limites definidos em lei específica;"). O Tribunal, por maioria, conheceu dos mandados de injunção e propôs a solução para a omissão legislativa com a aplicação, no que couber, da Lei 7.783/1989, que dispõe sobre o exercício do direito de greve na iniciativa privada. (MI 670/ES, rel. orig. Min. Maurício Corrêa, rel. p/ o acórdão Min. Gilmar Mendes, 25.10.2007; MI 708/DF, rel. Min. Gilmar Mendes, 25.10.2007; MI 712/PA, rel. Min. Eros Grau, $25.10 .2007)^{101}$

Importante observar que a omissão legislativa se materializa com a manifestação do Poder Judiciário, por meio de ação direta de inconstitucionalidade por omissão ou mandado de injunção, cuja decisão estabeleça o prazo fixando a mora legislativa, escoando o referido prazo, e não havendo qualquer manifestação do Poder Legislativo, fica caracterizado o dano ilícito.

\footnotetext{
${ }^{99}$ STF, Informativo $\mathbf{n}^{\mathbf{0}}$ 666, Tít.: Magistratura: lei estadual e competência legislativa - 3, PROCESSO - ADI 4393. Disponível em: < www.stf.gov.br >. Acesso em: 30 nov. 2012.

${ }^{100}$ Disponível em: 〈wwww.stf.jus.br $>$. Acesso em: 19 set. 2012.

${ }^{101}$ Disponível em: 〈www.stf.jus.br〉. Acesso em: 19 set. 2012.
} 


\subsubsection{Danos causados por lei inconstitucional}

Para Hely Lopes Meirelles ${ }^{102}$, o ato legislativo típico é a lei e, portanto, dificilmente causará danos indenizáveis ao particular, uma vez que, sendo norma abstrata e geral, incide sobre toda a coletividade, em decorrência da soberania do Estado. Somente em hipótese excepcional, uma lei inconstitucional poderia acarretar prejuízo ao particular, provocando o dano injusto e reparável. Nesse caso, se faz necessária a demonstração de culpa, assim a responsabilidade por atos legislativos seria de natureza subjetiva.

Para Meirelles, nas hipóteses de danos causados por lei inconstitucional, prevalece a teoria da irresponsabilidade, pois não haveria fundamento jurídico para a responsabilização da Administração por danos eventualmente causados por lei, ainda que declarada inconstitucional.

Yussef Said Cahali ${ }^{103}$, criticando o posicionamento de Hely Lopes Meirelles, diz que a responsabilidade indenizatória pelos danos causados ao particular por lei inconstitucional não comporta condicionantes, conforme extraídos em trecho que se aproveita:

O autor, depois de sua profissão de fé negativista da responsabilidade do Estado por prejuízo resultante do "ato legislativo típico, que é a lei", refere que "só excepcionalmente poderá uma lei inconstitucional atingir o particular uti singuli, causando-lhe dano injusto e reparável. Se tal ocorrer, necessária se torna a demonstração cabal de culpa do Estado, através da atuação de seus agentes políticos, mas isto se afigura indemonstrável no regime democrático em que o próprio povo escolhe os seus representantes para o Legislativo. Onde, portanto, o fundamento para a responsabilização da Fazenda Pública, se é a própria coletividade que investe os elaboradores da lei na função legislativa e nenhuma ação disciplinar têm os demais Poderes sobre os agentes políticos? Não encontramos, assim fundamento jurídico para a responsabilização civil da Fazenda Pública por danos eventualmente causados por lei, ainda que declarada inconstitucional ${ }^{104}$.

\footnotetext{
${ }^{102}$ MEIRELLES, Hely Lopes. Direito Administrativo Brasileiro. 37. ed. São Paulo: Malheiros, 2011. p. 707.

${ }^{103}$ CAHALI, Yussef Said. Responsabilidade Civil do Estado. 3. ed. São Paulo: Revista dos Tribunais, 2007. p. 526.

${ }^{104}$ MEIRELLES, Hely Lopes, Op. cit.. p. 707. Esse entendimento é prestigiado pela $14^{\mathrm{a}}$ Câmara Cível do TJSP, 09.09.1986, maioria, RJTJ 103/175.
} 
A despeito desse entendimento, o Supremo Tribunal Federal tem decidido pela responsabilização do Estado, se ficar comprovado que a lei inconstitucional causou dano ao particular (RDA 189/305 e 191/175) ${ }^{105}$.

De acordo com Lúcia Valle Figueiredo ${ }^{106}$, “o Estado responde por atos legislativos, no que se refere a leis inconstitucionais ou a leis discriminatórias, feitas com visível desvio de poder".

\subsubsection{Danos causados por lei constitucionalmente perfeita}

Em relação à responsabilidade do Estado por ato legislativo declarado constitucional, entendemos que mesmo uma lei perfeita constitucionalmente pode causar uma lesão injusta, tornando assim passível o Estado de reparar os danos perpetrados. Nem sempre as leis são genéricas e abstratas.

Saliente-se que é indenizável o dano oriundo de edição de lei constitucional que prejudique direitos e patrimônios individuais. Para o STF, o Estado tem o dever de indenizar os danos causados aos cidadãos por uma lei constitucional (RDA 189/305 e 191/175).

A posição adotada por José Cretella Junior aceita a responsabilidade estatal mesmo na hipótese de lei constitucional, quando ela arrebata certo número de pessoas, destacando que:

[...] a melhor doutrina admite, em nossos dias, não só a responsabilidade civil do Estado, no caso da lei inconstitucional, da lei que não obedeceu ao processo integral da tramitação legislativa, como também no caso da lei constitucional, formalmente perfeita, mas que sob a capa de generalidade aparente, verdadeira 'lei em tese', acaba por abranger um ou pouquíssimos indivíduos, equiparando-se, pois, de certo modo, ao ato administrativo ${ }^{107}$.

O Conselho de Estado francês, em 14 de janeiro de 1.938, reconhecendo o direito à indenização por ato legislativo, decidiu pela condenação do Estado em indenizar a Companhia La Fleurette. A referida fábrica ficou prejudicada pelos efeitos de uma lei que foi

\footnotetext{
${ }^{105}$ MEIRELLES, Hely Lopes Direito Administrativo Brasileiro. 37. ed. São Paulo: Malheiros, 2011. p.707, Nota de Rodapé 28/.

${ }^{106}$ FIGUEIREDO, Lúcia Valle. Curso de Direito Administrativo. 7. ed. São Paulo: Malheiros, 2004. p. 291.

${ }^{107}$ CRETELLA JR., José. O Estado e a obrigação de indenizar. Rio de Janeiro: Forense, 2002. p. 148.
} 
editada em meio a várias medidas que tinham o objetivo de proteger a indústria de laticínios, que naquele momento se encontrava em crise. A lei proibia a fabricação de produtos que poderiam substituir o leite. Apesar de ser uma norma genérica, na realidade, a medida proibitiva atingiu uma única indústria, perfeitamente identificada. Esse episódio ficou conhecido como "O caso La Fleurette"108.

\subsubsection{Imunidade Parlamentar}

Consideram-se imunidades parlamentares as prerrogativas que asseguram aos membros de parlamentos ampla liberdade, autonomia e independência no exercício de suas funções, protegendo-os contra abusos e violações por parte do poder executivo e do judiciário e podem ser diferenciadas em duas categorias, imunidade material e formal, mas há outras que devem ser consideradas nos termos do art. 53 da $\mathrm{CF} / 88$, cuja redação foi dada pela Emenda Constitucional 35, de 20 de dezembro de 2001, conforme se observa:

Art. $1^{\circ}$ - $\mathrm{O}$ art. 53 da Constituição Federal passa a vigorar com as seguintes alterações:

"Art. 53. Os Deputados e Senadores são invioláveis, civil e penalmente, por quaisquer de suas opiniões, palavras e votos.

$\S 1^{\circ}$ Os Deputados e Senadores, desde a expedição do diploma, serão submetidos a julgamento perante o Supremo Tribunal Federal.

$\S 2^{\circ}$ Desde a expedição do diploma, os membros do Congresso Nacional não poderão ser presos, salvo em flagrante de crime inafiançável. Nesse caso, os autos serão remetidos dentro de vinte e quatro horas à Casa respectiva, para que, pelo voto da maioria de seus membros, resolva sobre a prisão.

$\S 3^{\circ}$ Recebida a denúncia contra o Senador ou Deputado, por crime ocorrido após a diplomação, o Supremo Tribunal Federal dará ciência à Casa respectiva, que, por iniciativa de partido político nela representado e pelo voto da maioria de seus membros, poderá, até a decisão final, sustar o andamento da ação.

$\S 4^{\circ} \mathrm{O}$ pedido de sustação será apreciado pela Casa respectiva no prazo improrrogável de quarenta e cinco dias do seu recebimento pela Mesa Diretora.

$\S 5^{\circ}$ A sustação do processo suspende a prescrição, enquanto durar o mandato.

$\S 6^{\circ}$ Os Deputados e Senadores não serão obrigados a testemunhar sobre informações recebidas ou prestadas em razão do exercício do mandato, nem sobre as pessoas que lhes confiaram ou deles receberam informações.

${ }^{108}$ RIVERO, Jean; WALINE, Jean. Droit Administratif. 18. ed.. Paris: Dalloz, 2000. p. 300-301. 
$\S 7^{\circ} \mathrm{A}$ incorporação às Forças Armadas de Deputados e Senadores, embora militares e ainda que em tempo de guerra, dependerá de prévia licença da Casa respectiva.

$\S 8^{\circ}$ As imunidades de Deputados ou Senadores subsistirão durante o estado de sítio, só podendo ser suspensas mediante o voto de dois terços dos membros da Casa respectiva, nos casos de atos praticados fora do recinto do Congresso Nacional, que sejam incompatíveis com a execução da medida" (NR).

A Inviolabilidade, por opiniões, palavras e votos, abrange os parlamentares federais (art. 53, CF 88), os deputados estaduais (art. 27, § $1^{\circ}, \mathrm{CF} 88$ ) e, nos limites da circunscrição de seu Município, os vereadores (art. 29, VIII, CF 88) - sempre no exercício do mandato.

Para Alexandre de Moraes ${ }^{109}$,

[...] as imunidades são garantias funcionais, normalmente divididas em material e formal, são admitidas nas Constituições para o livre desempenho do ofício dos membros do Poder Legislativo e para evitar desfalques na integração do respectivo quorum necessário para deliberação.

A aplicabilidade da imunidade parlamentar pode ser classificada em duas modalidades distintas, quais sejam, a imunidade material e a imunidade formal. Desse modo, considerando a sua finalidade, o referido instituto se configura como uma garantia funcional, eivada de prerrogativas delineadas para a proteção do mandato legislativo e de outros direitos consectários.

A imunidade material implica na isenção da responsabilidade penal, civil, disciplinar ou política do parlamentar por suas opiniões, palavras ou votos.

A imunidade formal é o instituto que impede a impossibilidade de o parlamentar ser ou permanecer preso ou, ainda, a hipótese de sustação do andamento da ação penal por crimes praticados após a diplomação.

\subsection{RESPONSABILIDADE POR OMISSÃO NA ATIVIDADE JURISDICIONAL}

O debate sobre a indenizabilidade de atos juridicionais danosos suscita polarizações semelhantes. Há autores que defendem que esses atos não seriam passíveis de

${ }^{109}$ MORAES, Alexandre de. Direito Constitucional. 27. ed. São Paulo: Atlas, 2011. p. 460. 
indenização, pois o Poder Judiciário, pelo princípio da divisão dos poderes, seria soberano em suas decisões. Por outro ângulo, a indenização seria impertinente, uma vez que os juízes são independentes para decidir em conformidade com o Direito, além de não serem servidores administrativos. E por derradeiro, admitir a indenização por ato judicial violaria o princípio da imutabilidade da coisa julgada ${ }^{110}$.

Entretanto, os partidários da indenizabilidade defendem que, sendo, os serviços judiciários, serviço público, cabe ao Estado ressarcir os danos oriundos dos atos jurisdicionais emanados pelos magistrados, quando estes forem lesivos a terceiros ou eivados de vício (culpa ou dolo do agente ou erro). Nesse sentido, o Magistrado agiria em nome do Estado ao prestar a tutela jurisdicional e os danos causados por ele no exercício dessa atividade seriam passíveis de indenização. Seria pertinente o ajuizamento de ação regressiva contra o juiz que tenha dado ensejo à imputação de condenação ao Estado, na hipótese de ele ter agido com culpa ou dolo. A fundamentação legal para esse argumento reside no artigo $5^{\circ}$, inciso LXXV, da Constituição Federal vigente, in verbis:

Art. $5^{\circ}-$

LXXV - O Estado indenizará o condenado por erro judiciário, assim como o que ficar preso além do tempo fixado na sentença.

Lúcia Valle Figueiredo ${ }^{111}$, expondo seu posicionamento, exprime que:

Quanto a nós, não vemos empeços para responsabilizar o Estado por atos praticados por uma de suas funções, a judiciária. Efetivamente, encarna o Judiciário também a figura do agente público, de alguém que diz o Direito em normas concretas e por conta do Estado. Se assim é, dentro de certas comportas, que o regime jurídico da função postula, há de ser também responsabilizado na hipótese de lesão.

Muito embora a doutrina majoritária se posicione favoravelmente à indenizabilidade dos atos praticados pelo Poder Judiciário que venham a causar danos a terceiros, o Supremo Tribunal Federal não tem reconhecido de forma irrestrita a admissibilidade desse instituto. Para a Corte Suprema, somente seria cabível indenização nas hipóteses previstas em lei, não havendo aplicação do artigo $37, \S 6^{\circ}$ da Constituição vigente. A decisão transcrita a seguir ilustra com clareza esse posicionamento:

\footnotetext{
${ }^{110}$ DI PIETRO, Maria Sylvia Zanella. Direito Administrativo. 24. ed. São Paulo: Atlas, 2011. p.662-664.

${ }^{111}$ FIGUEIREDO, Lúcia Valle. Curso de Direito Administrativo. 7. ed. São Paulo: Malheiros, 2004. p. 287.
} 
CONSTITUCIONAL.ADMINISTRATIVO.CIVIL.RESPONSABILIDADE CIVIL DO ESTADO. ATOS DOS JUIZES. C.F. ART. 37, § $6^{\circ}, \mathrm{I}-\mathrm{A}$ responsabilidade objetiva do Estado não se aplica aos atos dos juízes, a não ser nos casos expressamente declarados em lei. Precedentes do Supremo Tribunal Federal, II - Decreto judicial de prisão preventiva não se confunde com erro judiciário, $\mathrm{CF} / 88$, art. $5^{\circ}$. LXXV, mesmo que o réu, ao final da ação penal, venha a ser absolvido. III - Negativa de trânsito ao RE Agravo não provido. (STF - 2 $2^{\mathrm{a}}$ Turma - RE $429518 \mathrm{AgR} / \mathrm{SC}-$ Rel. Min. Carlos Velloso - DJ 28.10.2004 pg. 49).

Se, de um lado, o Supremo Tribunal Federal não apresenta qualquer disposição em reconhecer o cabimento da responsabilidade do Estado por danos causados em decorrência da atividade jurisdicional, de outra banda, o Superior Tribunal de Justiça tem decisões mais arrojadas sobre o tema. O principal acórdão que ofereceu demonstração desse tratamento diferenciado foi o proferido por ocasião do julgamento do Recurso Especial, sob a relatoria do Ministro Luiz Fux, que reconheceu o direito à indenização à pessoa que, após ter sido preventivamente presa, foi posteriormente absolvida, in verbis ${ }^{112}$ :

PROCESSO CIVIL. ERRO JUDICIÁRIO, ART. 5', LXXV, DA CF. PRISÃO PROCESSUAL POSTERIOR ABSOLVIÇÃO. INDENIZAÇÃO. DANOS MORAIS.

1. a prisão por erro judiciário ou permanência do preso por tempo superior ao determinado na sentença, de acordo com o art. $5^{\circ}$, LXXV, da CF, garante ao cidadão o direito à indenização.

2. Assemelha-se à hipótese de indenizabilidade por erro judiciário, a restrição preventiva da liberdade de alguém que posteriormente vem a ser absolvido. A prisão injusta revela ofensa à honra, à imagem, mercê de afrontar o mais comezinho direito fundamental à vida livre e digna. A absolvição futura revela a ilegitimidade da prisão pretérita, cujos efeitos deletérios para a imagem e honra do homem são inequívocos (notoria non egent probationem).

3. O pedido de indenização por danos decorrentes de restrição ilegal à liberdade inclui o "dano moral", que in casu, dispensa prova de sua existência pela inequivocacidade da ilegalidade da prisão, duradoura por nove meses. Pedido implícito, encartado na pretensão às "perdas e danos". Inexistência de afronta ao dogma da congruência (arts. $2^{\circ}$, 128 e 460 do CPC).

4. A norma jurídica inviolável no pedido não integra a causa petendi. “ $\mathrm{O}$ constituinte de 1988, dando especial relevo e magnitude ao status libertatis, inscreveu no rol das chamadas franquias democráticas uma regra expressa que obriga o Estado a indenizar o condenado por erro judiciário ou quem permanecer preso por tempo superior ao fixado pela sentença $\left(\mathrm{CF}\right.$, art. $5^{\circ}$, LXXV), situações essas equivalentes a de quem submetido à prisão processual e posteriormente absolvido."

\footnotetext{
${ }^{112}$ REsp 427560, Acórdão unânime da primeira turma, relator Min. Luiz Fux, publicado no DJ em 30/09/2002. p. 204.
} 
5. A fixação dos danos morais deve obedecer aos critérios da solidariedade e exemplaridade, que implica a valoração da proporcionalidade do quantum e a capacidade econômica do sucumbente.

6. Recurso especial desprovido. (grifo do relator). ${ }^{113}$

Nesse sentido, Helena Elias Pinto ${ }^{114}$ reconhece que "Em matéria de responsabilidade civil do Estado por ato jurisdicional, o Supremo Tribunal Federal tem entendido que se encontra pacificado no sentido de que somente nos casos previstos expressamente em lei o Estado tem o dever de indenizar".

A responsabilidade objetiva não se aplica aos atos do Poder Judiciário em sua função jurisdicional, a não ser nos casos expressamente declarados em lei. Com esse entendimento, a Turma, por ofensa ao art. $37, \S 6^{\circ}$, da CF, conheceu de recurso extraordinário do Estado do Paraná e lhe deu provimento para reformar acórdão do Tribunal de Justiça estadual, que reconhecera o direito de indenização a adquirente de imóvel com base no presumido error in judicando do juiz que anulara a venda do bem por fraude à execução -já que o mesmo era objeto de penhora -, cuja penhora não havia sido arquivada no cartório de registro de imóveis, sem prova da má-fé do adquirente. Precedentes citados: RE 32.519-RS (RTJ 39/190); RE 69.568-SP (RTJ 56/273). RE 219.117-PR, rel. Min. Ilmar Galvão, 3.8.99 (Informativo $\mathrm{n}^{\circ}$ 156, disponível em <www.stf.gov.br, Acesso em 12 de janeiro de 2007).

A responsabilidade do Estado por dano decorrente da atividade jurisdicional defeituosa tem evoluído mais lentamente em comparação com a responsabilidade por danos decorrentes da atuação dos agentes públicos no exercício da função administrativa.

\subsubsection{Atividades judiciais e jurisdicionais}

Ato judicial é gênero do qual são espécies os atos jurisdicionais e os atos administrativos praticados pelo Poder Judiciário. Os atos jurisdicionais têm força de coisa julgada, são atos típicos do Poder Judiciário.

\footnotetext{
${ }^{113}$ REsp 427560, Acórdão unânime da primeira turma, relator Min. Luiz Fux, publicado no DJ em 30/09/2002. p. 204. Apud PINTO, Helena Elias. Responsabilidade Civil do Estado por Omissão - Na Jurisprudência do Supremo Tribunal Federal. Rio de Janeiro: Lúmen Júris, 2008. p. 209.

${ }^{114}$ PINTO. Helena Elias. Responsabilidade Civil do Estado por Omissão - Na Jurisprudência do Supremo Tribunal Federal. Rio de Janeiro: Lúmen Júris, 2008. p. 197.
} 
Para Hely Lopes Meirelles ${ }^{115}$, “quanto aos atos administrativos praticados por órgãos do Poder Judiciário e do Legislativo, se equiparam aos demais atos da Administração, e, se lesivos, empenham a responsabilidade civil objetiva da Fazenda Pública”.

Edmir Netto de Araújo ${ }^{116}$ afirma que, na realidade, a melhor técnica para a definição da atividade judicial é o enfoque ratione personae. Desta forma, tudo que emerge do magistrado do Poder Judiciário será atividade judicial, quer se considere o aspecto formal, quer o material de seus atos.

Assim, teremos a atividade judiciária como gênero, do qual decorrem duas espécies: a atividade contenciosa (aplicação contenciosa da lei ao caso concreto), que é a atividade jurisdicional, básica e específica, atividade fim do Poder Judiciário; e a de natureza voluntária, graciosa (não contenciosa), qualificada em termos gerais como administrativa, exercida também intensamente pelo Poder Judiciário, mas como atividade-meio, por isso secundária e inespecífica.

A expressão ato jurisdicional tem sentido lato, compreendendo a própria sentença e as circunstâncias em que é prolatada ${ }^{117}$.

A atuação judiciária propriamente dita, a atividade jurisdicional típica de dizer o direito no caso concreto contencioso ou na atividade denominada de jurisdição voluntária sujeita o magistrado à responsabilidade de que trata o artigo 133, do Código de Processo Civil $^{118}$.

Em suas conclusões, porém, Carlos Roberto Gonçalves reconhece que as mais modernas tendências apontam para a direção da admissão da responsabilidade civil do Estado pelos danos experimentados por particulares, decorrentes do exercício da atividade judiciária $^{119}$.

\footnotetext{
115 MEIRELLES, Hely Lopes. Direito Administrativo Brasileiro. 37. ed., atualizada por Eurico Andrade Azevedo, Décio Balestero Aleixo e José Emmanuel Burle Filho. São Paulo: Malheiros, 2011. p. 708.

${ }^{116}$ ARAÚJO, Edmir Netto de. Curso de Direito Administrativo. São Paulo: Saraiva, 2010. p. 835.

${ }^{117}$ ARAÚJO, Edmir Netto de. Responsabilidade do Estado por Ato Jurisdicional. São Paulo: Revista dos Tribunais, 1981.p. 179.

${ }^{118}$ GONÇALVES, Carlos Roberto. Responsabilidade Civil. 13. ed. São Paulo: Saraiva, 2011. p. 261.

119 Idem, Ibidem. p. 265.
} 


\subsubsection{Natureza da função jurisdicional}

A atividade jurisdicional, como qualquer prática da vida humana, está sujeita a erros. A busca pela efetivação da justiça é realizada por seres humanos, simples criaturas desprovidas de infalibilidade. Aliada a essa certeza, há também a falta de atenção, os aspectos psicológicos e emocionais, o transcurso do tempo, entre outras causas que são fatores que podem resultar na má observância dos fatos que permeiam o processo judicial.

Se não houvesse órgãos jurisdicionais hierarquicamente superiores para controlar e reexaminar as decisões proferidas por órgãos inferiores, se instauraria o caos. Mesmo assim, valendo-se do uso do reexame, há um momento em que se esgotam todas as instâncias e a sentença final torna-se inatacável. Por essa razão, uma decisão injusta ou equivocada, a inércia ou a morosidade é prejudicial não somente para a parte sucumbente, mas também para toda a Sociedade que perde a confiança na Justiça.

A função jurisdicional é aquela realizada pelo poder Judiciário, tendo em vista aplicar a lei a uma hipótese controvertida, mediante processo regular, produzindo, afinal, coisa julgada, com o que substitui, definitivamente, a atividade e vontade das partes. ${ }^{120}$

A ação que busca a responsabilidade do Estado não requer distinção entre os atos administrativos, legislativos ou jurisdicionais, mas apenas a prova do dano e de que foi causado por agente público.

\subsubsection{Atos jurisdicionais: responsabilidade pessoal do juiz}

O Juiz é um agente público, segundo a regra consagrada no artigo $37, \S 6^{\circ}$ da Constituição Federal de 1.988. Agente público é todo aquele que, sob qualquer categoria ou título jurídico, desempenha função ou atividade considerada pelo Estado como pertinente à sua condição e prerrogativa de Poder Público. Aquele que desempenha atividade estatal, enquanto o fizer, será um agente público.

Muitos são aqueles que procuram afastar a responsabilidade do Estado por danos provocados por atividades jurisdicionais, valendo-se dos mais variados argumentos ${ }^{121}$. Houve

${ }^{120}$ DINIZ, Maria Helena. Curso de Direito Civil Brasileiro, Responsabilidade Civil. vol. 7. 19. ed. São Paulo: Saraiva, 2004. p. 653. 
época em que se procurava afastar a ideia de responsabilização do Estado em decorrência de dano provocado pela atividade jurisdicional, argumentando-se que os juízes não seriam, de forma alguma, mas especialmente para fins de responsabilidade estatal, "representantes" ou "prepostos" 122 do Estado, mas órgãos da soberania nacional, independentes. Assim, não seriam também funcionários públicos ${ }^{123}$.

De acordo com Álvaro Lazzarini, "A responsabilidade civil é do Estado. Este, insistimos, é que, se caso, pode responsabilizar o juiz, em ação regressiva." Discordando de Hely Lopes Meirelles, nos seguintes termos:

Assim, sem razão, com a devida vênia, Hely Lopes Meirelles quando afirma que fica o juiz, individual e civilmente, responsável pela omissão ou o retardamento injustificável de providências de seu ofício, nos expressos termos do art. 133 do CPP, sem que essa responsabilidade individual se transmita, nem solidariamente, à Fazenda.

Segundo Maria Helena Diniz ${ }^{124}$, “A má fé, abuso ou desvio de poder do magistrado, por constituírem ato ilícito, dão origem à responsabilidade do Estado, mas o juiz responderá pelo seu ato, na ação regressiva, se agiu com dolo”.

O Código de Processo Penal, introduzido no ordenamento jurídico pelo Decreto

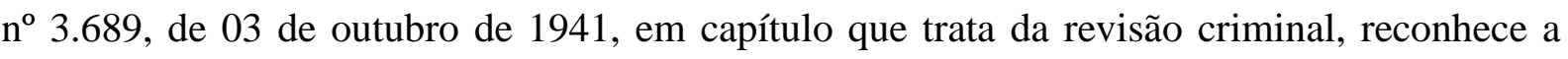
responsabilidade do Estado por ato jurisdicional em decorrência de erro judiciário, nos termos do artigo 630, in verbis:

Art. 630 - O tribunal, se o interessado requerer, poderá reconhecer o direito a uma justa indenização pelos danos sofridos.

Álvaro Lazzarini ${ }^{125}$ entende que, na hipótese do art. 630 do CPP, dificilmente o Estado será responsabilizado por omissão na atividade jurisdicional criminal que possa

${ }^{121}$ ARAÚJO, Edmir Netto de. Responsabilidade do Estado por Ato Jurisdicional. São Paulo: Revista dos Tribunais, 1981. p. 132.

${ }^{122}$ Acórdão do STF, de 29.10.1926, em Revista do Direito, v. 86. p. 536: "Não é a União civilmente responsável pelas decisões contenciosas ou administrativas proferidas pelo Poder Judiciário, porque este não é representante ou preposto dela, mas um dos órgãos da soberania nacional.

${ }^{123}$ Decisão do juiz Cunha Mello, em 9.1.1936, Arquivo Judiciário, v. 37. p. 274: "Mas sendo assim, como de fato é, não se configure na hipótese um caso de responsabilidade civil do Estado que, em regra, apenas responde por culpa ou negligência de seus funcionários ou prepostos, e, como tais, a melhor doutrina, sufragada entre nós pela jurisprudência, não conceitua os julgadores membros do Poder Judiciário".

${ }^{124}$ DINIZ, Maria Helena. Curso de Direito Civil Brasileiro, Responsabilidade Civil. Vol. 7. 19. ed. São Paulo: Saraiva, 2004. p. 649.

${ }^{125}$ LAZZARINI, Álvaro. Estudos de Direito Administrativo. 2. ed. São Paulo: Revista dos Tribunais, 1999. p. 438. 
eventualmente ser reconhecida no julgamento de revisão criminal, pois ele considera a revisão criminal de "limitada amplitude".

A revisão criminal pode ser pleiteada a qualquer tempo, mesmo que o réu já haja cumprido pena ou esteja em fase de cumprimento, tenha ocorrido ou não a extinção da punibilidade ou tenha ele morrido. Não existe prazo, mesmo porque o objetivo da revisão criminal não se restringe a impedir o cumprimento de uma pena injusta, mas, principalmente corrigir uma injustiça, restabelecendo-se, com a rescisão do julgado, a dignidade do condenado.

O artigo 1.744, incisos I, do Código de Civil de 2.002, determina a responsabilidade direta e pessoal do magistrado, em hipótese específica de não nomeação de tutor ou nomeação inoportuna, entretanto o referido dispositivo não exclui a responsabilização do Estado por eventuais danos.

Da mesma forma, o artigo 133, Código de Processo Civil, também estabelece a responsabilização do magistrado quando no exercício de suas funções agir com dolo ou praticar fraude, e ainda recusar, omitir ou retardar, sem justo motivo, providência que deva determinar de ofício ou a requerimento da parte.

Por fim, convém repetir e enfatizar a posição de Edmir Netto de Araújo que demonstra, literalmente, e mostra, com abundância de argumentos, que o juiz é funcionário público lato sensu, incluído, por isso mesmo, na acepção a que o art. 37, § $6^{\circ}$, da Constituição Federal de 1.988 se refere ao estabelecer a responsabilidade estatal com base no risco, segundo o qual " [...] havendo dano ao particular, e configurando inequivocadamente o nexo causal (Estado - omissão ou ação do dano do administrado), observadas as excludentes de responsabilidade [...] isto será suficiente para o estabelecimento da obrigação indenizatória da Administração Pública"126.

Celso Antônio Bandeira de Mello ${ }^{127}$ entende que, embora muito estritamente, a reparação por atos jurisdicionais já é admitida, o que, para ele, é um marco extremamente avançado da teoria da responsabilização do Estado.

\footnotetext{
${ }^{126}$ ARAÚJO, Edmir Netto de. Responsabilidade do Estado por Ato Jurisdicional. São Paulo: Revista dos Tribunais, 1981. p. 34. Essa posição de Edmir Netto de Araújo também é acolhida por DIAS, José de Aguiar. Da Responsabilidade Civil. 12. ed. Rio de Janeiro: Lumen Juris, 2011. p. 662.

${ }^{127}$ BANDEIRA DE MELLO, Celso Antônio. Curso de Direito Administrativo. 28. ed. São Paulo: Malheiros, 2010.
} 


\subsubsection{Erro judiciário: penal e civil}

A atividade ou função jurisdicional manifesta-se, em essência, pelo julgamento ou ato jurisdicional. $\mathrm{O}$ ato jurisdicional, clímax do funcionamento dos serviços judiciários, pode produzir danos os mais variados, entre os quais o mais grave é o erro judiciário, que implica a própria negação da justiça, a não ser que possibilite, no devido tempo, a respectiva reparação $^{128}$.

A sentença pode ser errada, tanto no cível quanto no crime. Na esfera criminal, poderá levar o réu à prisão, e causar-lhe prejuízos morais e patrimoniais sérios. Identificado o erro, em qualquer circunstância, o prejudicado ajuizará ação pelo rito ordinário de indenização contra o Estado, e este, por sua vez, indenizará em pecúnia, nos termos constitucionais.

Edmir Netto de Araújo compreende por erro judiciário a sentença equivocada "quer seja em um processo criminal quer tenha origem em um procedimento não-penal"129.

Yussef Said Cahali, tratando dessa questão, leciona que:

As raízes do instituto e sua evolução histórica determinam o desdobramento do tema conforme se trate de dano consequente da atividade jurisdicional penal ou da atividade jurisdicional civil. Esta discriminação, inclusive, determina uma diversidade de nomenclaturas: tradicionalmente, quando se fala em erro judiciário, sem ulteriores especificações, trata-se de erro judiciário no juízo criminal. Mas existem erros judiciários fora da órbita penal; estes demais erros estão compreendidos nos atos judiciais, de que aquele é mera especialização ${ }^{130}$.

Adiante, o mesmo autor arremata:

Aliás, essa discriminação também facilita o encaminhamento do tema, pois, a rigor, sempre houve disciplina legal específica quanto à responsabilidade civil do Estado pelo chamado erro judiciário, agora ampliada para o caso em que o condenado "ficar preso além do tempo fixado na sentença" (art. $5^{\circ}$, LXXV, da CF de 1988); instaurando-se a controvérsia em sede específica da responsabilidade do Estado pelos danos decorrentes de seu monopólio na

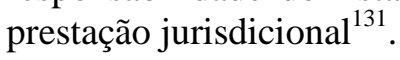

\footnotetext{
${ }^{128}$ CRETELLA JR., José. Responsabilidade do Estado por atos judiciais. Rio de Janeiro: Revista Forense, $\mathrm{n}^{\circ}$ 230, abr./jun. 1970. p. 38.

129 ARAUJO, Edmir Netto. Responsabilidade do Estado por Ato Jurisdicional. São Paulo: Revista dos Tribunais, 1981. p. 113.

${ }^{130}$ CAHALI, Yussef Said. Responsabilidade Civil do Estado. 3. ed. São Paulo: Revista dos Tribunais, 2007. p. 472.

${ }^{131}$ Idem, Ibidem. p. 472 (grifos do autor).
} 
A história está repleta de exemplos de casos de erros judiciários. Entre tantos podemos citar o famoso e mundialmente conhecido "Caso Dreyfus ${ }^{132}$ ". Quando se apresentou no edifício de Guerra, em Paris, em uma manhã de outubro de 1894, atendendo uma convocação, o Capitão Alfred Dreyfus, oficial francês da artilharia, nem imaginava que havia uma trama arquitetada por outro oficial, o Major Esterhazy, para incriminá-lo por traição. A acusação estava baseada apenas e tão somente em um documento encontrado em um cesto de lixo por uma serviçal, intitulado de "borderaux". Coube a um oficial ávido por mostrar serviço e fortemente antissemita - característica comum em grande parte da sociedade francesa da época - conduzir as investigações, que apontaram o Capitão Dreyfus como autor do documento. Entretanto, cinco anos mais tarde, provou-se sua inocência. O caso ganhou repercussão mundial, houve manifestação de toda a intelectualidade, políticos, jornalistas, juristas, houve muita revolta em torno do caso.

O jurista e jornalista brasileiro Rui Barbosa, na época dos fatos, exilado em Londres, foi a primeira voz que se levantou contra um dos maiores erros judiciários da literatura jurídica. Rui Barbosa protestou contra as graves irregularidades do processo que levaram à condenação e deportação de Alfred Dreyfus para a Ilha do Diabo. Antecipava-se, em três anos, à carta aberta do escritor Émile Zola - “J'acuse" -, alertando para o que viria a ser um dos maiores erros judiciários de todos os tempos.

Edmir Netto de Araújo, em obra de grande envergadura sobre o tema, traz diversos exemplos de erros judiciários tanto no contexto nacional quanto internacional. ${ }^{133} \mathrm{No}$ âmbito internacional, o já citado e talvez o mais famoso "Caso Dreyfus", acompanhado do “caso do Padeiro da Ilha de Malta”, no início do século XVIII ${ }^{134}$.

No Brasil, pelo menos três casos são conhecidos na literatura como exemplos de erros judiciários: (a) o "Caso Mota Coqueiro", em Macaé-Rio de Janeiro, ocorrido em $1.852^{135}$; (b) O igualmente famoso "Caso do irmãos Naves" ${ }^{136}$, ocorrido em 1.938 , em

\footnotetext{
${ }^{132}$ BEGLEY, Louis. O Caso Dreyfus, Ilha do Diabo, Guantánamo e o pesadelo da histórica. Tradução Laura Teixeira Motta. São Paulo: Companhia das Letras, 2010.

133 ARAUJO, Edmir Netto. Responsabilidade do Estado por Ato Jurisdicional. São Paulo: Revista dos Tribunais, 1981. p. 144-150.

${ }^{134}$ Idem, Ibidem. p. 144-146.

${ }^{135}$ LUIS CARLOS, Lazinha. Erros Judiciários. São Paulo: Vaner Bígego, 1973. v. 1. p. 11-36.

${ }^{136}$ Idem, Ibidem. p. 37-67.
} 
Araguari-MG; e, ainda, (3) o "Crime do Citröen Negro", ocorrido no Rio de Janeiro em $1.952^{137}$.

Dessa forma, concluímos que o erro judiciário, muito embora seja imediatamente associado às hipóteses no âmbito do processo penal, pode também ocorrer em qualquer processo judicial (civil, trabalhista, previdenciário etc.), haja vista os casos de anulação de sentença em ação rescisória, carecendo, ao nosso entender, de inegável direito à indenização por erro judiciário, sobremaneira nos casos em que se observa que a sentença foi dada por prevaricação, concussão, corrupção do juiz, ou proferida por juiz impedido ou absolutamente incompetente, nos termos do art. 485, I e II do $\mathrm{CPC}^{138}$.

\subsection{A RESPONSABILIDADE DO AGENTE PÚBLICO}

A expressão "agentes públicos" não tem sido utilizada com frequência pela legislação brasileira. A norma constitucional poucas vezes se utiliza do vocábulo agente ${ }^{139}$, optando por "servidor público". De qualquer forma, são consideradas agentes públicos, todas as pessoas físicas que, de forma permanente ou transitória, prestam serviços ao Estado. $\mathrm{O}$ agente público já foi denominado de funcionário público, servidor, empregado, representante etc. Agente público é gênero do qual o funcionário estatutário, empregado público, agente político e particulares em colaboração, são espécies.

Aristóteles ${ }^{140}$ dizia que:

Em todo governo, existem três poderes essenciais, cada um dos quais o legislador prudente deve acomodar da maneira mais conveniente. Quando estas três partes estão bem acomodadas, necessariamente o governo vai bem, e é das diferenças entre estas partes que provêm as suas. $\mathrm{O}$ primeiro destes três poderes é o que delibera sobre os negócios do Estado. O segundo compreende todas as magistraturas ou poderes constituídos, isto é, aqueles

\footnotetext{
137 ARAUJO, Edmir Netto. Responsabilidade do Estado por Ato Jurisdicional. São Paulo: Revista dos Tribunais, 1981. p. 148-150.

${ }^{138}$ PANTALEÃO, Juliana F.; MARCOCHI, Marcelo C.. Indenização: erro judiciário e prisão indevida. In: Jus Navigandi, Teresina, ano 9, n. 416, 27 ago.2004 . Disponível em: <http://jus.com.br/revista/texto/5642>. Acesso em: 7 jan. 2013.

${ }^{139} \mathrm{Cf}$. artigo 37 , parágrafo $5^{\circ}$ e $6^{\circ}$ e artigo $5^{\circ}$, inciso LXIX.

${ }^{140}$ ARISTÓTELES. A Política. Tradutor Nestor Silveira Chaves. Coleção Clássicos Edipro. 2. ed. São Paulo: Edipro, 2009. p. 113.
} 
de que o Estado precisa para agir, suas atribuições e a maneira de satisfazêlas. O terceiro abrange os cargos de jurisdição.

Hely Lopes Meirelles considera que os agentes públicos são servidores públicos em sentido amplo, que se consubstanciam em todos aqueles que se vinculam à Administração Pública, direta e indiretamente, sob o regime jurídico (a) estatutário regular, geral ou peculiar, ou (b) administrativo especial, ou, ainda, (c) celetista (regido pela Consolidação das Leis do trabalho CLT), de natureza profissional e empregatícia ${ }^{141}$.

Para Odete Medauar ${ }^{142}$, os vocábulos utilizados para designar aqueles que mantêm vínculo de trabalho com entes estatais apresentam-se nebulosos:

$\mathrm{Na}$ linguagem comum, inclusive usada pela imprensa falada e escrita, mencionam-se, com frequência, os termos funcionalismo, funcionários, servidores, para abranger todos os que trabalham na Administração ou num setor; são muito comuns as expressões "greve no funcionalismo", greve dos funcionários do Correio.

$\mathrm{Na}$ linguagem técnico-jurídica reina confusão, parecendo difícil fixar com nitidez o sentido das diversas expressões existentes. A Constituição Federal dá preferência à expressão servidores públicos, com a qual intitula uma seção; usa também o termo servidor em quase todos os dispositivos da matéria. Assim, a Constituição Federal atribui a essa locução o sentido amplo, que tradicionalmente se conferia à expressão agentes públicos, para abranger todos aqueles que mantêm vínculo de trabalho com o Poder Público. Em textos legais menos recentes, é dado sentido amplo à expressão funcionário público, pois era a de uso mais frequente antes da Constituição Federal de 1988 - por exemplo, o artigo 327 do Código Penal (grifos da autora).

Sejam quais forem as denominações que se queira utilizar, e independentemente do critério que se adote para classificá-las, o agente público aparece como a expressão mais ampla que se pode conceber para designar genérica e indistintamente as pessoas que expressam a vontade ou a ação do Estado, no exercício da função pública, ainda quando o façam apenas ocasional ou esporadicamente.

Quando o dano é causado pelo agente, agindo nessa qualidade, a um particular, o regime de responsabilidade para a reparação é o da responsabilidade do Estado, com a regressividade contra o agente causador do dano, nos termos do artigo $37, \S^{\circ}{ }^{\circ}$, da $\mathrm{CF} / 88$.

Alexandre de Moraes ${ }^{143}$ pondera que a responsabilidade do Estado não se confunde com a responsabilidade do agente público; a absolvição do agente público não

\footnotetext{
${ }^{141}$ MEIRELLES, Hely Lopes. Direito Administrativo Brasileiro. 37. ed., atualizada por Eurico Andrade Azevedo, Décio Balestero Aleixo e José Emmanuel Burle Filho. São Paulo: Malheiros, 2011.p. 454.

${ }^{142}$ MEDAUAR, Odete. Direito Administrativo Moderno. 16. ed. São Paulo: Revista dos Tribunais, 2012. p. 293.
} 
desobriga o Estado de indenizar o prejuízo suportado pela vítima. Na seara estatal, o termo "responsabilidade" pode ser considerado gênero, do qual são espécies: a responsabilidade penal, a responsabilidade disciplinar ou funcional, a responsabilidade fiscal, a contábil, e, por fim, a responsabilidade civil.

O agente público que estiver fora de suas atividades funcionais e vier a causar danos a uma terceira pessoa não obriga o Estado a responder por esses danos, visto que o Estado, por força do artigo 37, § $6^{\circ}$, da Constituição, não responderá pelos danos que seus agentes causarem a outrem quando não estiverem exercendo sua função, ou em razão dela ${ }^{144}$.

O Estado, sendo pessoa jurídica, ou seja, entidade abstrata que não tem vontade nem ação própria, no sentido de manifestação psicológica e vida anímica - características típicas dos seres humanos - manifesta sua vontade e sua ação pela atuação por seus prepostos, na proporção que se apresentam revestidos desta qualidade.

Conforme já citamos no capítulo anterior, a responsabilidade dos agentes públicos, em lugar do Estado, foi consagrada na Constituição Federal de 1.824, no item 29 do artigo 179, ressalvado o Imperador, que não estava submetido a qualquer tipo de responsabilização, nos termos do artigo 99 da mesmo documento legal.

A Lei 8.112, de 11 de dezembro de 1.990, que dispõe sobre o Regime Jurídico dos Servidores Públicos Civis da União, das Autarquias e das Fundações Públicas Federais, determina, no artigo 121, que "O servidor responde civil, penal e administrativamente pelo exercício irregular de suas atribuições".

\subsubsection{Responsabilidade penal ou criminal}

A responsabilidade penal é aquela que se configura pela lesão à paz social, e José Cretella Jr., citando Aguiar Dias, ensina que:

A ação repressiva não tem por objetivo o dano causado ao particular, como particular, mas a este como integrante do grupo. Se a responsabilidade civil pretende reprimir o dano privado, restabelecendo o equilíbrio 'individual'

\footnotetext{
${ }^{143}$ MORAES, Alexandre. Constituição do Brasil Interpretada e Legislação Constitucional. 7.ed. São Paulo: Atlas, 2007. p. 896.

${ }^{144}$ BÜHRING, Márcia Andréa. Responsabilidade Civil Extracontratual do Estado. São Paulo: Thomson-IOB, 2004. p. 165.
} 
perturbado, a responsabilidade penal tem a finalidade de restabelecer o equilíbrio 'social' perturbado, indagando, antes da imputabilidade do agente e da antissocialidade de seu procedimento ${ }^{145}$.

Em regra, não é possível atribuir ao Estado responsabilidade penal, ao menos nos mesmos parâmetros em que essa responsabilidade é imputada à pessoa natural ${ }^{146}$, assim como a quaisquer pessoas jurídicas de direito público ou privado. A responsabilização penal, quando configurada, recairá sobre o agente público, assim como recairia sobre qualquer cidadão, na evidência de ato ilícito reconhecido como conduta tipificada na legislação penal.

\section{Para Mônica Nicida Garcia ${ }^{147}$ :}

A responsabilidade criminal do agente público é aquela decorrente da prática de crime, definido como tal, pela lei. Os crimes praticados por agentes públicos no exercício de sua função são, de maneira geral, identificados como crimes contra a Administração Pública. Deve ficar claro, entretanto, que pelas normas que os definem, pretende-se garantir a tutela não só da Administração Pública, em sentido estrito, mas de toda a atividade estatal, incluídas a atividade legislativa e a judicial.

A responsabilidade penal do agente é pessoal e individual. Ademais, a imposição de pena pela prática de um delito, tipificado como crime, nos remete à correção de um comportamento socialmente inadequado e que provoca uma lesão na sociedade, atingindo todos os indivíduos. Para o convívio social harmônico, é necessária a manutenção de um comportamento moral e eticamente adequado por todos os indivíduos.

Os crimes contra a Administração Pública, praticados por agentes públicos (há aqueles praticados por particulares, como a corrupção ativa e a sonegação fiscal) são chamados de crimes funcionais e estão previstos em diversas normas jurídicas. A principal, sem dúvida, é o Código Penal (decreto-Lei no 2.848, de 7 de dezembro de 1940), que traz no Título XI os crimes contra a Administração Pública, definindo, no Capítulo I (arts. 312 a 361), os crimes praticados por funcionário público contra a Administração em geral. ${ }^{148}$

\footnotetext{
${ }^{145}$ CRETELLA JR., José. Responsabilidade do Estado por atos judiciais. 2.ed.Rio de Janeiro: Forense, 2002. p. 36.

${ }^{146}$ Sobre a Responsabilidade penal da pessoa jurídica, verificar item "1.1 - Definição de Responsabilidade do Estado" no primeiro capítulo.

${ }^{147}$ GARCIA, Mônica Nicida. Responsabilidade do Agente Público. 2. ed. Belo Horinzonte: Fórum, 2007 p. 141.

${ }^{148}$ Idem, Ibidem. p. 142.
} 


\subsubsection{Responsabilidade administrativa}

Já a responsabilidade administrativa ou disciplinar é aquela que versa apenas e tão somente sobre o agente público, pois decorre do princípio da hierarquia e, ainda, deve ser aferida a partir do cotejo entre a conduta do agente público e o Regulamento estabelecido pela própria Administração Pública. A responsabilidade disciplinar é importante na medida em que a ausência de disciplina torna a máquina administrativa deficiente, prejudicando sobremaneira a prestação do serviço público ao administrado.

A Lei 8.112/90, que dispõe sobre o Regime Jurídico dos Servidores Públicos Civis da União, das autarquias e das fundações públicas federais, estabelece, no seu artigo 124, que: "A responsabilidade civil-administrativa resulta de ato omissivo ou comissivo cometido no desempenho do cargo ou função", e as sanções civis, penais e administrativas poderão cumular-se, sendo independentes entre si (art. 125).

$\mathrm{Na}$ infração de regras de conduta relativa a trabalho e emprego dos agentes públicos, bem como às atividades por eles desempenhadas no exercício de suas funções, teremos a responsabilidade administrativa, que pode se desdobrar em responsabilidade disciplinar ou funcional ${ }^{149}$.

Segundo Edmir Netto de Araújo, "Hierarquia, classicamente, é a relação de coordenação e de subordinação dos órgãos do Poder Executivo, tendo como consequências, entre outras, o dever de obediência, a aplicação de sanções administrativas, a revisão de atos dos subordinados" $" 150$.

O referido autor chama atenção, ainda, para o fato de que muito embora a responsabilidade disciplinar e a responsabilidade administrativa sejam tratadas indiscriminadamente pela doutrina majoritária como sendo a mesma coisa, pois denomina-se genericamente como, disciplinar, mesmo quando não diga respeito à disciplina ou elação hierárquica, tal classificação não é cientificamente exata ${ }^{151}$.

De acordo com o entendimento de Hely Lopes Meirelles:

Responsabilidade administrativa é a que resulta da violação de normas internas da Administração pelo servidor sujeito ao estatuto e disposições

\footnotetext{
${ }^{149}$ ARAUJO, Edmir Netto de. O Ilícito Administrativo e seu processo. São Paulo: Revista dos Tribunais, 1994. p. 54.

${ }^{150}$ ARAUJO, Edmir Netto de. Curso de Direito Administrativo. 5. ed. São Paulo:Saraiva. 2010.p. 767.

${ }^{151}$ Idem, Ibidem. p. 768.
} 
complementares estabelecidas em lei, decreto ou qualquer outro provimento regulamentar da função pública ${ }^{152}$.

Edmir Netto de Araújo ${ }^{153}$ destaca que:

Em sentido amplo, responsabilidade administrativa é aquela à qual está sujeito o agente público por qualquer ato praticado no exercício de suas atribuições legais, infringente das normas administrativas, podendo ocorrer ou não a qualificação penal adicional, e, não raro, a responsabilidade patrimonial (civil) decorrente. Já em sentido estrito, significa a obrigação de responder perante a Administração pela prática de ilícito administrativo na infração de regras de conduta relacionadas à função pública, desdobrando-se em ilícito disciplinar e funcional (grifo do autor).

\subsubsection{Responsabilidade contábil}

A responsabilidade contábil advém da obrigação do agente público de prestar contas de dinheiro ou valores pertencentes ao erário, antes mesmo do advento da Lei de Responsabilidade Fiscal. Cretella Júnior classifica tal encargo como responsabilidade contábil, "contas mal prestadas ou insuficientemente documentadas, pagamento não autorizado, embora feitos a credor legítimo, dão origem à responsabilidade contábil, sem necessidade de dano efetivo ou desaparecimento de valores" ${ }^{154}$. Na mesma linha de raciocínio, segue Edmir Netto de Araújo ${ }^{155}$.

\subsubsection{Responsabilidade civil}

A responsabilidade civil é aquela que decorre de ação ou omissão, dolosa ou culposa, direta ou indireta, de alguém, cujo resultado se consubstancia no prejuízo de outrem. Apesar da responsabilidade civil do Estado se configurar em tema distinto daquele que se

\footnotetext{
${ }^{152}$ MEIRELLES, Hely Lopes. Direito Administrativo Brasileiro. 37. ed. São Paulo: Malheiros. p. 543.

${ }^{153}$ ARAUJO, Edmir Netto de. O Ilícito Administrativo e seu processo. São Paulo: Revista dos Tribunais, 1994. p. 55.

${ }^{154}$ CRETELLA JR., José. Responsabilidade do Estado por atos judiciais. 2.ed. Rio de Janeiro: Forense, 2002. p. 40.

${ }^{155}$ ARAUJO, Edmir Netto de. Op. cit. p. 766.
} 
refere à Responsabilidade civil do agente, não se pode deixar de destacar que ambas caminharam simultaneamente.

A responsabilidade civil do agente público tem por objetivo reparar o dano que este tenha causado à Administração Pública ou a terceiro, em decorrência de conduta culposa ou dolosa, de caráter comissivo ou omissivo. Contudo, para que o agente seja responsabilizado, deverá correr contra ele um processo administrativo a fim de se apurar se realmente o dano ocorreu e quem foi o real agente causador da lesão, devendo haver ainda nexo de causalidade entre o agente e o dano praticado.

Para imputar-se a responsabilidade civil ao agente, é necessário que haja a comprovação do resultado danoso; sendo prejudicada a Administração ou o terceiro, inexistindo dano, não há que se falar em responsabilização, por isso, se mostra de fundamental relevância o processo administrativo disciplinar que, como visto, tem por objetivo averiguar a ocorrência do dano e a existência do nexo causal para, finalmente, responsabilizar o efetivo agente ocasionador do dano possivelmente existente.

Se o dano for causado à Administração Pública, o agente público é perante ela diretamente responsável, entretanto, se é causador de danos a terceiros, pode o agente responder diretamente, sendo acionado pela vítima, ou indiretamente, sendo acionado pelo próprio Estado, por meio de ação regressiva como consequência do processo por ela sofrido.

José Cretella Júnior, citando Amaro Cavalcanti, esclarece que:

Não é preciso acrescentar que a responsabilidade civil significa, tão somente, a obrigação de prestar uma reparação pecuniária que restabeleça a situação patrimonial anterior do lesado, isto é, faça desaparecer a lesão sofrida por alguém no seu direito patrimonial. É porque a responsabilidade civil tem este caráter, que na pessoa jurídica é também considerada suscetível de pena, quando esta se reduz, por exemplo, a multas ou outras imposições de natureza simplesmente pecuniária $^{156}$.

${ }^{156}$ CAVALCANTI, Amaro. Responsabilidade Civil do Estado. Rio de Janeiro: Laemmert, 1905. p. 218 e nota 11 apud CRETELLA JR., José. O Estado e a obrigação de indenizar. Rio de Janeiro: Forense, 2002. p. 42. 


\subsubsection{Responsabilidade Política}

A responsabilidade política, na qual incorre quem pratica ato tipificado como crime de responsabilidade (expressão utilizada para identificar uma infração políticoadministrativa) é peculiar aos agentes políticos. As demais espécies de responsabilidade são atribuíveis a todos os agentes públicos, inclusive os agentes políticos ${ }^{157}$.

Os agentes políticos, espécies do gênero "agentes públicos", exercem funções públicas, que absorvem tanto a prática de atos políticos, quanto a prática de simples atos administrativos. Em qualquer caso, porém, não são isentos de responsabilidade, que é algo elementar ao sistema republicano, adotado em nossa Constituição.

Segundo Mônica Nicida Garcia ${ }^{158}$ :

O que diferencia a atuação do agente político daquela dos demais agentes públicos é o fato de estar ela marcada pela tomada de decisões e pela escolha entre opções políticas, o que justifica a plena liberdade ou independência funcional de que goza, desempenhando suas atribuições com prerrogativas e responsabilidades próprias, estabelecidas na Constituição e em leis especiais.

A legislação pátria prevê determinadas condutas que classifica como crimes de responsabilidade, nas penas em que podem incidir alguns agentes políticos. Apesar de receberem essa denominação - crimes - não se estão esses ilícitos dentro da esfera de responsabilidade criminal dos agentes públicos. Com efeito, a doutrina mais autorizada tem caracterizado os crimes de responsabilidade como infrações político-administrativas ou político-disciplinares ${ }^{159}$. Conforme as ponderações de Alexandre Rezende da Silva ${ }^{160}$ :

[...] o Estado, ainda que não na atividade administrativa, mas na política, mas ainda assim Estado, é que faz a lei, natural que ao impô-la deva observá-la, sempre com vistas a uma democracia. Do contrário, ou seja, se quem faz a lei não se obrigar a ela também, estar-se-á estabelecendo uma verdadeira arbitrariedade e iniquidade.

${ }^{157}$ DALLARI, Adilson Abreu. A responsabilidade do agente político. In: Jus Navigandi, Teresina, ano 5, n. 42, 1 jun.2000. Disponível em: <http://jus.com.br/revista/texto/354>. Acesso em: 7 jan. 2013.

${ }^{158}$ GARCIA, Mônica Nicida. Responsabilidade do Agente Público. 2. ed. revista e ampliada. Belo Horizonte: Fórum, 2007. p. 33.

${ }^{159}$ Idem, Ibidem. p.157

${ }^{160}$ SILVA, Alexandre Rezende da. Princípio da legalidade. In: Jus Navigandi, Teresina, ano 8, n. 63, 1 mar. 2003. Disponível em: 〈http://jus.com.br/revista/texto/3816>. Acesso em: 18 jul. 2012. 
Nesse diapasão, vale destacar os argumentos de Adilson Abreu Dallari ${ }^{161}$ :

Na verdade, atualmente, existe um verdadeiro caos legislativo em matéria de responsabilidade política. Conforme o específico agente político, será de aplicar-se a mencionada lei federal, as Constituições e leis estaduais, os regimentos internos das casas legislativas, as leis orgânicas municipais e até mesmo (parcialmente) o decreto-lei $\mathrm{n}^{\circ}$ 201/67, no caso de prefeitos e vereadores.

Não se questiona, todavia, a possibilidade de responsabilização de agentes políticos pela prática de atos políticos. O julgamento é político, mas devem ser observadas as garantias constitucionais inerentes à ampla defesa e à representação política. A sanção aplicável será a perda do mandato ou do cargo e, também, a inabilitação para o exercício de função pública (motivo pelo qual entendemos que a renúncia do acusado não impede a instauração ou o prosseguimento de processo).

\subsubsection{Responsabilidade pela prática de ato de improbidade administrativa}

Sabe-se que o ato administrativo é a manifestação unilateral do Estado ou alguma entidade que o represente no exercício de suas prerrogativas, buscando, baseado na lei, o atendimento de um fim público: adquirir, modificar, declarar, resguardar, transferir, extinguir ou impor obrigações aos administrados.

Diógenes Gasparini ensina que: "Diz-se perfeito o ato administrativo quando completo ou formado. Vale dizer, quando naturalmente nada lhe falta; quando sem motivo, conteúdo, finalidade, forma, causa e assinatura da autoridade competente. Em suma: Quando o ato existe" $" 162$.

Hodiernamente é o artigo $37, \S 4^{\circ}$, da Constituição Federal vigente que se apresenta como principal fonte normativa sobre a matéria. De acordo com esse dispositivo, os atos de improbidade administrativa provocam a suspensão dos direitos políticos, a perda da função pública, a indisponibilidade dos bens e o ressarcimento ao erário, sem prejuízo da ação penal cabível $^{163}$.

\footnotetext{
${ }^{161}$ DALLARI, Adilson Abreu. A responsabilidade do agente político. In: Jus Navigandi, Teresina, ano 5, n. 42, 1 jun.2000. Disponível em: <http://jus.com.br/revista/texto/354>. Acesso em: 7 jan. 2013.

${ }^{162}$ GASPARINI, Diógenes. Direito Administrativo. 17. ed. São Paulo: Saraiva, 2012. p. 66.

${ }^{163}$ CARVALHO FILHO, José dos Santos. Manual de Direito Administrativo. 25. ed. São Paulo: Atlas. 2012. p. 1060.
} 
Conforme leciona José dos Santos Carvalho Filho ${ }^{164}$ :

Ação de improbidade administrativa é aquela em que se pretende o reconhecimento judicial de condutas de improbidade na Administração, perpetradas por administradores públicos e terceiros, e a consequente aplicação das sanções legais, com o escopo de preservar o princípio da moralidade administrativa. Sem dúvida, cuida-se de poderoso instrumento de controle judicial sobre atos que a lei caracteriza como de improbidade (grifo do autor).

A Improbidade Administrativa, portanto, já tem lugar garantido dentro do Direito Administrativo. "[...] A doutrina brasileira que se tem dedicado ao estudo da improbidade administrativa, ou, mais, especificamente, da Lei de Improbidade Administrativa (Lei $\mathrm{n}^{\circ}$ 8.429/92) associa unanimemente, o conceito de improbidade com o conceito de moralidade". 165

Particularmente, a norma legal reguladora da improbidade administrativa é a Lei 8.429, de 2 de junho de 1.992 (LIA), cuja estrutura se compõe de cinco pontos fundamentais: (a) o sujeito passivo; (b) o sujeito ativo; (c) a tipologia da improbidade; (d) as sanções; (e) os procedimentos administrativo e judicial. A LIA, muito embora trate especificamente desta temática, não é a única norma jurídica que se destina à proteção de diversos valores na Administração Pública e prevê medidas e sanções com o intuito de protegê-los.

\subsection{RESPONSABILIDADE INOMINADA DO ESTADO}

Há hipóteses em que não se identifica um agente público que tenha praticado ato danoso ou se omitido da obrigação de fazê-lo, ou ainda, casos em que o prejuízo suportado pelo terceiro tenha ocorrido em virtude da atividade do Estado, assim temos configurada a denominada responsabilidade inominada do Estado, ou culpa anônima do serviço público ${ }^{166}$.

Também é comum o fato de veículos, trafegando em vias públicas, perderem a direção, em decorrência de defeitos na pista, quando o leito carroçável se avizinha de rios ou córregos, e os veículos acabam caindo no seu interior. A falta de grades de proteção nas estradas, nas pontes ou em lugares perigosos, a ausência de sinalização adequada indicando

\footnotetext{
${ }^{164}$ CARVALHO FILHO, José dos Santos. Manual de Direito Administrativo. 25. ed. São Paulo: Atlas. 2012. p. 1059.

${ }^{165}$ GARCIA, Mônica Nicida. Responsabilidade do Agente Público. 2. ed. revista e ampliada. Belo Horizonte: Fórum, 2007. p.157.
}

${ }^{166}$ Nesse sentido: ARAUJO, Edmir Netto de. Curso de Direito Administrativo. 5. ed. São Paulo: Saraiva, 2010. p. 791. 
valas, buracos ou deformidades na pista, que oferecem perigo aos administrados, se configuram em graves omissões da Administração Pública, que tem o dever jurídico de garantir bem-estar, segurança e tranquilidade aos membros da Sociedade.

O dever de indenizar um prejuízo suportado está fundado no princípio da solidariedade social, segundo o qual todos arcam com o ônus da lesão sofrida por um dos membros do grupo. Ao administrado bastará apenas e tão somente demonstrar que a atividade estatal ou sua omissão na construção, manutenção ou conservação de equipamentos públicos foi ensejadora de resultado danoso.

\subsubsection{Danos decorrentes de tempestades, enchentes e desabamentos}

Em 1.972, Antônio Carlos Brasileiro de Almeida Jobim (Tom Jobim) compôs os belos versos para cantar em dueto com Elis Regina Carvalho Costa (Elis Regina) "[...] São as águas de março fechando o verão, é promessa de vida no meu coração[...]”. Esses versos deixam evidente o que todos sabem: março é o mês das águas.

Eventos naturais como temporais ou chuvas torrenciais em volume acima do tolerável, em que a força das águas causa enchentes e inundações, ou mesmo chuvas constantes e de pouca intensidade são considerados como fenômenos imprevisíveis e inevitáveis, mas podem provocar danos ao particular, evitáveis, pois o resultado é conhecido e é passível de ser mitigado, se providências forem tomadas. Se, por exemplo, a Administração Pública executasse obras com o objetivo de propiciar o escoamento rápido e uniforme das águas da chuva, provendo, assim, a infraestrutura necessária para que as intempéries não prejudicassem o particular além do que seria justo exigir-lhe ${ }^{167}$.

A Administração Pública deve responder não pelo fato da natureza em si, mas por não ter executado obras suficientemente adequadas a fim de evitar o resultado danoso ou simplesmente amenizar seus efeitos, quando o fato for notório e perfeitamente previsível, como acontece na maioria das cidades sujeitas a enchentes, deslizamentos de morros, quedas de árvores, desabamento de encostas etc. Exemplo claro ocorre em vários Municípios dos Estados Brasileiro, mais frequentemente no Rio de Janeiro onde, todo ano, durante o mês de

\footnotetext{
${ }^{167}$ Nesse sentido: OLIVEIRA, José Carlos de. Responsabilidade Patrimonial do Estado, Danos Decorrentes de Enchentes, Vendavais e Deslizamentos, São Paulo: Edipro, 1995. p. 56.
} 
janeiro, amargam-se os efeitos das chuvas, chegando muitas vezes, a ser decretado estado de emergência. A violência das águas destrói estradas e vias públicas, provoca deslizamentos cobrindo de barro casas e soterrando famílias, deixando-as desabrigadas.

A responsabilização do Estado nesses casos ocorre por sua atuação permanecer situada abaixo do padrão normal de diligência minimamente exigível; exemplo disso são os erros no dimensionamento de calhas e condutos, obstáculos à livre vazão das águas ocasionados por lançamento de detritos nas vias públicas, obstrução de galerias e bocas de lobo que são mal dimensionadas, além da falta de limpeza dos bueiros e córregos que deve ser realizada com certa frequência, principalmente na época de chuvas.

A falta de interesse e o pouco empenho da Administração na realização de obras públicas de pouca visibilidade acarretam toda sorte de infortúnio aos cidadãos. A responsabilização do Estado é manifesta quando, pela incúria, deixa de executar obras necessárias para afastar os efeitos nefastos das chuvas, bastando a imprevidência na manutenção e conservação de galerias pluviais para se acentuar seu dever de reparar os danos suportados pelo particular.

Segundo José Carlos de Oliveira ${ }^{168}$, advogando pela responsabilização do Estado, nos casos de deficiência na prestação do serviço público, posicionamento do qual compartilhamos,

\begin{abstract}
A chuva forte, em si, não caracteriza um caso de força maior no qual o Poder Público se exonere da responsabilidade. A consequência, ou seja, o transbordamento dos cursos d'água, é devida quase sempre à deficiência da execução de obras e serviços públicos. Compete à administração demonstrar, para elidir sua responsabilidade, a frequência dos serviços de limpeza e que a chuva ultrapassou à normalidade, e assim caracterizando-se verdadeiramente caso de força maior, estará isenta da responsabilidade patrimonial (RJTJESP 1981, v. 69/1036-5).
\end{abstract}

Por outro lado, contrapondo-se ao excesso de águas nas regiões Sul, Sudeste e Centro-Oeste, há em outras regiões brasileiras, mais precisamente no Norte e Nordeste, o problema da escassez de chuvas por longos períodos, que acarreta a seca que castiga o povo sertanejo. É perfeitamente possível prever e precaver-se das consequências perniciosas da excessiva falta de chuvas, bem como neutralizar os efeitos da estiagem perturbadora.

A seca, como conhecemos, pode ser definida como o fenômeno climático causado pela insuficiência de precipitação pluviométrica, numa determinada região por um período de

168 OLIVEIRA, José Carlos de. Responsabilidade Patrimonial do Estado, Danos decorrentes de Enchentes, Vendavais e Deslizamentos. São Paulo: Edipro, 1995. p. 69. 
tempo muito grande. É necessário que haja por parte do Poder Público um conjunto de ações capazes de resolver esse problema antigo que se tornou crônico. A seca é um câncer social, que tem solução, mas que reclama vontade política para ser solucionado.

Em 1.904, Euclydes da Cunha ${ }^{169}$ propôs uma cruzada contra a seca no Nordeste que incluía pesquisas científicas, construção de estradas melhorando o acesso, açudes, poços, estradas estruturadas, bem como o desenvolvimento de projetos para o desvio das águas.

Numa comunidade atrasada e ignorante, a ruína pode ser completa, resultado do despovoamento ou uma grande redução demográfica, pela emigração forçada ou pela morte em decorrência da fome ou de doenças como desnutrição, desidratação etc., antes, porém, proporciona enormes sofrimentos.

A obra literária "Os Sertões", de Euclydes da Cunha, revela que a seca é uma fatalidade inexorável, entretanto perfeitamente previsível, podendo ter seus efeitos mitigados ou mesmo eliminados:

[...] o aparecimento das secas, no século passado e atual, se defronta em paralelismo singular, sendo de presumir que ligeiras discrepâncias indiquem apenas defeitos de observação ou desvios na tradição oral que as registrou.

De qualquer modo ressalta à simples contemplação uma coincidência repetida bastante para que se remova a intrusão do acaso.

Assim, para citarmos apenas as maiores, as secas de 1710-1711, 1723-1727, 1736-1737, 1744-1745, 1777-1778, do século XVIII, se justapõem às de 1808-1809, 1824-1825, 1835-1837, 1844-1845, 1877-1879, do atual ${ }^{170}$.

Em outro trecho, o autor deixa evidente o descaso e o esquecimento a que estão fadados os habitantes daquela região:

Como quer que seja, o penoso regime dos Estados do Norte está em função de agentes desordenados e fugitivos, sem leis ainda definidas, sujeitas às perturbações locais, derivadas da natureza da terra, e a reações mais amplas, promanadas das disposições geográficas. Daí as correntes aéreas que o desequilibram e variam ${ }^{171}$.

\footnotetext{
${ }^{169}$ Euclydes Rodrigues Pimenta da Cunha nasceu em 20 de janeiro de 1866, no Rio de Janeiro, e morreu em 15 de agosto de 1909, foi um escritor, sociólogo, repórter jornalístico, historiador, geógrafo, poeta e engenheiro brasileiro. Foi um dos primeiros escritores brasileiros a retratar a miséria e o isolamento a que estava condenada a população do Nordeste brasileiro, diagnosticando o subdesenvolvimento de um Brasil mergulhado na opressão semi-feudal do latifúndio, na servidão e na dureza do meio. Na obra "Os Sertões", ele reproduz a Guerra de Canudos, entretanto, antes disso, faz um levantamento de dados geográficos e culturais da região nordestina, estudando o clima, o solo, a fauna e a flora. Ao descrever o homem, habitante daquele ambiente, afirma que " $o$ sertanejo é antes de tudo, um forte", mesmo se tranformando em um retirante estropiado que abandona sua terra, em busca da sobrevivência.

${ }^{170}$ CUNHA, Euclydes da. Os Sertões campanha de Canudos. 39. ed. Rio de Janeiro: Livraria Francisco Alves Editora, 2000. p. 33-34.

${ }^{171}$ Idem, Ibidem, 2000. p. 35.
} 
Por outro lado, se o mesmo fenômeno, qual seja, a deficiência da queda pluvial, incidisse do mesmo modo numa região onde a população possuísse nível de instrução mais elevado, os resultados da irregularidade climática poderiam ser atenuados e até neutralizados e não acarretariam qualquer abalo econômico ou social, tendo em vista a possibilidade de autonomia do sertanejo, que poderia encontrar soluções específicas para esse problema.

Há falta de políticas públicas visando a educar o sertanejo a viver de forma inteligente aproveitando os recursos nas épocas de alto nível chuvas, com o objetivo de prevenir, com razoável eficácia os efeitos físicos, sociais e econômicos decorrentes de uma longa estiagem.

É necessário que o problema das secas seja tratado com a técnica adequada, observe-se a falta de elementos essenciais para oferecer às populações sujeitas aos embates da estiagem uma educação, que embora elementar e simples, seja adequada e compatível com seu meio geográfico e social.

Nessa constatação, não há qualquer ideologia ou viagem fantasiosa, mas sim a observação e experiência secular, analisadas sob múltiplos aspectos, haja vista a seca alterar a dinâmica social e econômica de determinada região.

Graciliano Ramos ${ }^{172}(1.892$ - 1.953) - em sua obra "Vidas Secas", publicada em 1938 e considerada um clássico da literatura brasileira, que retrata o sofrimento de uma família de retirantes nordestinos, reproduzindo a situação vivida por milhares de outros, vitimados pela seca castigadora - mostra-nos uma realidade não muito diferente da atual, na qual a injustiça social, a fome, a miséria material e moral e, principalmente, a desigualdade permeiam os tristes episódios suportados pela família do protagonista Fabiano.

Constatam-se tais assertivas nos seguintes trechos:

[...] Os infelizes tinham caminhado o dia inteiro, estavam cansados e famintos.

[...] A catinga estendia-se de um vermelho indeciso salpicado de manchas brancas que eram ossadas.

[...] Miudinhos, perdidos no deserto queimado, os fugitivos agarraram-se, somaram as suas desgraças e os seus pavores.

Euclydes da Cunha afirmava que o sertanejo é, antes de tudo, um forte. O homem hostilizado pelo ambiente, pela terra, pelas cidades, devorado pelos problemas que o meio lhe impõe precisa de amparo do Estado, e este tem o dever de ampará-lo.

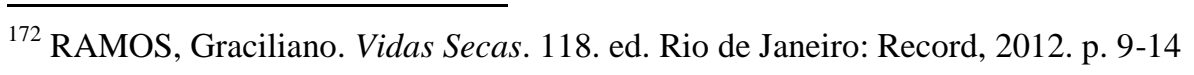


O fundamento da responsabilidade estatal nos casos de danos oriundos de enchente, secas e outros fenômenos atmosféricos, assim considerados, encontra suporte na teoria do risco administrativo, exigindo, para sua configuração, a prova da ocorrência do dano, o nexo de causalidade e a imputabilidade ao ente público.

\subsubsection{Movimentos sociais e multitudinários}

Movimentos multitudinários ou atos coletivos, de acordo com os ensinamentos de José Cretella Júnior ${ }^{173}$, podem ser expressados como "deslocamentos de povos ou de parte da população, como consequência de fatos sociais, políticos ou econômicos que ocorrem num dado momento histórico".

Os movimentos multitudinários dão ensejo à intervenção dos agentes policiais guardiães da ordem pública, no exercício legítimo do poder de polícia de que são detentores, uma vez que está a cargo do Estado a garantia da propriedade particular, da segurança e da integridade física do cidadão, obrigando-se aquele a esmerar-se nesse propósito. Tais movimentos não se configuram em conduta penalmente punível, pois são perpetrados por um grupo de indivíduos que, diante de um incidente social, econômico ou político, pratica ato que, analisado isoladamente, configuraria crime ou contravenção, considerando que tal conduta causa dano ao particular.

A falta de previsão no ordenamento jurídico que tipifique os movimentos multitudinários como contravenção penal ou até mesmo crime conduz à necessidade de análise do comportamento isolado de cada ato praticado pelos membros integrantes do aglomerado que cause dano ao particular, para, a partir daí, se concluir se houve conduta típica, antijurídica e culpável.

Entretanto, há situações em que a força policial comparece, mas apenas assiste impassível à destruição do patrimônio de terceiros, sem nada poder fazer, pois o furor da multidão é tão intenso que os agentes policiais deixam de agir movidos pela prudência, caso contrário, a ação policial resultaria em verdadeiro massacre. Nesses casos, a omissão estatal, apesar de perfeitamente justificável, não isenta o Estado de reparar os danos suportados por terceiros.

\footnotetext{
${ }^{173}$ CRETELLA JR., José. O Estado e a Obrigação de Indenizar. 2. ed. Rio de Janeiro: Forense, 2002. p. 212.
} 
Durante a revolução de 1.930 , foi julgado um caso em que se condenou a União Federal por danos verificados decorrentes de movimento de massa, por falta de garantia e assistência policial aos particulares (Acórdão de 03.05.1945, do STF, RDA, 5:15) ${ }^{174}$.

Segundo Sônia Sterman ${ }^{175}$ movimentos sociais é gênero do qual são espécies de movimentos para fins de responsabilização do Estado: os movimentos multitudinários, os movimentos populares (semelhantes ao sem-terra, sem-teto, os movimentos ufanistas em época de competições esportivas, as torcidas de futebol organizadas em estádios em dias de jogos, os de natureza pacífica), os movimentos organizados nas penitenciárias brasileiras, e os movimentos terroristas.

A concepção de movimentos sociais tornou-se mais ampla nas últimas décadas, subdividindo-os naqueles de natureza popular, os movimentos pacíficos e os de natureza criminosa e terrorista. Não devemos nos esquecer que a motivação é, via de regra, de natureza social, política ou econômica.

Buscando as origens, observamos que os movimentos multitudinários de caráter político-social surgiram com o advento da Revolução Francesa, mais precisamente com a queda da Bastilha, desenvolvendo seus fundamentos na doutrina e na jurisprudência, inclusive determinando os princípios básicos da responsabilidade do Estado e a própria autonomia do direito administrativo. Foi, também, a partir daí, que surgiu a definição de multidão e massa, sob os aspectos penal, sociológico e psicológico.

Merecem todo cuidado e atenção por parte do Estado os movimentos disparados por multidões, motins populares ou movimentos de massa permeados de discursos inflamados que exaltam os ânimos, promovidos em espaços públicos (praças, ruas, avenidas etc.) que podem levar a consequências imprevisíveis. Sabe-se como começam, mas não se pode prever como terminam, sendo muito comuns em tempo de crise ou mesmo de guerra, em que o inconsciente coletivo toma o controle sobre a razão individual e singular.

Os sociólogos examinam os movimentos de multidão definindo-os como aqueles nos quais, o indivíduo, atuando no seio da multidão, se despersonaliza, agindo de forma diversa da sua conduta individual.

Sônia Sterman ${ }^{176}$, apontando o estudo dos comportamentos de massa sob a ótica da psicologia, recorda a questão do inconsciente coletivo suscitada por Jung:

\footnotetext{
${ }^{174}$ CRETELLA JR., José. O Estado e a Obrigação de Indenizar. 2. ed. Rio de Janeiro: Forense, 2002. p. 214.

${ }^{175}$ STERMAN, Sônia. Responsabilidade do Estado. 2. ed. São Paulo: Revista dos Tribunais, 2011. p. 22.

${ }^{176}$ Idem, Ibidem. p. 37-38.
} 
Para Jung, a psique coletiva é separada da individual, mas o reconhecimento de que os deuses e demônios não eram realidades indiscutíveis, mas conteúdo do inconsciente, só aconteceu a partir do Iluminismo, quando se passou à compreensão de que os deuses não eram figuras reais, mas meras projeções. Daí concluir que os movimentos violentos produzidos pelas multidões nada mais são do que a liberação do irracional do inconsciente de cada indivíduo que foi reprimido pelo movimento político-social anterior.

Os movimentos populares não são novidades da Era Moderna ou Contemporânea, e os movimentos de caráter reivindicatório, principalmente por motivos políticos, ocorrem desde a Antiguidade. Fustel de Coulages ${ }^{177}$, em sua clássica obra "A Cidade Antiga", traz vários exemplos de movimentos ocorridos naquela época, mais precisamente na Grécia e na Itália.

Quando, depois de umas revoluções conseguiu-se a igualdade, não existindo mais razão para combater por princípios e direitos, os homens guerrearam-se por interesses. Esse novo período da história das cidades não começou na mesma época pra todas. Em algumas seguiu de muito perto o estabelecimento da democracia; em outras, apareceu só depois de várias gerações que souberam se governar com calma. Mas todas as cidades cedo ou tarde caíram em lutas lastimáveis.

Os movimentos multitudinários não podem ser confundidos com outros tipos de movimentos populares, como por exemplo: a rixa, o linchamento, os movimentos ufanistas, uma vez que suas características são divergentes, senão vejamos.

A rixa é um movimento popular que não está embasado em questões políticas, sociais ou econômicas, também não há convergência de interesses entre seus integrantes que brigam entre si, agredindo-se mutuamente e atingindo a integridade física de outrem, e seu exercício configura em conduta penal passível de punição contra aqueles que estiverem envolvidos.

O linchamento também difere dos movimentos multitudinários admitidos pela ordem jurídica, porque seu objetivo consiste em castigar um indivíduo premeditadamente, muitas vezes, levando-o até a morte. Observe-se que o linchamento contraria os princípios gerais de justiça, pois os envolvidos acreditam estar exercendo a justiça pelas próprias mãos.

Tanto a rixa quanto o linchamento não obrigam o Estado a indenizar o particular que sofreu o dano, porque admitir-se que o Poder Público deveria indenizar todos os danos advindos de delitos seria uma verdadeira incongruência.

${ }^{177}$ FUSTEL DE COULANGES. A Cidade Antiga. 2. ed. São Paulo: Martin Claret Editora, 2012. p. 360. 
De acordo com o posicionamento de Sônia Sterman ${ }^{178}$, o Estado não pode ser responsabilizado por danos causados em virtude movimentos multitudinários, pois, para ela, a omissão, falha ou falta de um serviço de prestação de segurança, não refreando a multidão não é causa de dano. Segue a autora, afirmando que a teoria do risco administrativo adotada atualmente se aplica apenas nos casos em que as lesões tenham sido causadas pelos agentes da administração (servidores) que, nessa qualidade, produziram contra terceiros. Sterman defende que o Estado não pode responder por danos causados por atos de terceiros ou fenômenos da natureza.

Maria Garcia ${ }^{179}$, em sua obra "Desobediência Civil", aponta, desde logo, já na Nota Introdutória da primeira edição, que objetiva destacar a reflexão sobre o exercício da cidadania, em que o ápice é a fruição do direito à liberdade. A cidadania reclama instrumentalização ampla e efetiva, porquanto o seu exercício não se exaure no rol de direitos e garantias expressos na atual Carta Constitucional. A autora aborda, de forma suscinta, o "direito de resistência", proclamado por vários autores e filósofos - tais como J. H. Meirelles Teixeira, Georges Bourdeau, São Tomás de Aquino, Thomas Morus, Platão, entre outros para expor as manifestações de ideias revolucionárias ${ }^{180}$.

Quando Maria Garcia advoga em favor da desobediência civil, lastreando seus argumentos nos ideais de Hannah $\operatorname{Arendt}^{181}$ (O direito de ter direitos), não está estimulando a desordem, tampouco fazendo apologia aos movimentos violentos, mas reforçando o exercício da cidadania por meio da resistência pacífica, a objeção de consciência e a manifestação de opinião.

Sônia Sterman defende que a responsabilidade do Estado pelos danos causados por movimentos multitudinários é fundamentada na responsabilidade subjetiva prevista atualmente nos artigos 186 e 927, caput, do Código Civil de 2002. Ela mesma aponta posicionamento divergente expresso por Rui Berdford Dias, José Aguiar Dias, Gustavo Tependino $^{182}$.

\footnotetext{
${ }^{178}$ STERMAN, Sônia. Responsabilidade do Estado. 2. ed. São Paulo: Revista dos Tribunais, 2011. p. 129.

${ }^{179}$ GARCIA, Maria. Desobediência Civil. 2. ed. São Paulo: Revista dos Tribunais, 2004. p. 7.

${ }^{180}$ Idem, Ibidem. p. 153.

${ }^{181}$ HANNAH ARENDT nasceu na Alemanha em 14/10/1906 e morreu em Nova Iorque em 04/12/1975; foi uma das figuras mais importantes da filosofia e do pensamento político ocidental no século XX, seu trabalho filosófico abarca temas como a política, a autoridade, o totalitarismo, a educação, a condição laboral, a violência, e a condição de mulher, a cidadania etc.

${ }^{182}$ STERMAN, Sônia. Op. Cit. p.134-135.
} 
O Estado deve reconhecer o direito do cidadão de manifestar livremente sua opinião, deve permitir-lhes reunir-se na busca pelos seus anseios e ideais ou mesmo em comemorações e festejos - como acontece em jogos de futebol -, mas deve também, o Estado, vigiar para que essas manifestações ocorram de modo a não causar danos a terceiros, rechaçando, quando houver a mínima possibilidade de tal ameaça; é o seu dever in vigilando.

O Estado tem o dever jurídico de indenizar prejuízos causados, até mesmo por atos de vandalismo, que surgem das situações mais variadas, como por exemplo, em estádios de futebol, logradouros públicos etc. O argumento de que é impossível para o Estado estar presente em todos os lugares públicos ao mesmo tempo e algumas situações eclodem de afogadilho, não sendo passíveis de previsibilidade, não merece prosperar, pois admitindo tal hipótese, estaria afastando a responsabilidade do Estado também nas hipóteses de caso fortuito.

Sendo os movimentos populares ou mesmo os conflitos previsíveis, como por exemplo, encontro de torcidas de futebol sabidamente rivais (Palmeiras e Corinthians), retomada de imóvel originada por ocupação irregular de áreas por movimentos de sem-teto ou sem-terra, causando danos aos administrados, caberá a respectiva reparação, em decorrência do dever do Estado de proporcionar aos cidadãos segurança e garantias à sua incolumidade física e patrimonial, afinal é também por isso que se pagam impostos.

\subsubsection{Fatos de guerra. Movimentos revolucionários e movimentos terroristas}

Muito embora o Brasil seja signatário das quatro Convenções de Genebra de 1.949 e de seus protocolos adicionais de 1.977 , o ordenamento jurídico interno relacionado ao tempo de guerra está restrito ao direito penal militar.

Os fatos de guerra provocam lesões ocasionadas por operações militares, orquestradas pelas forças armadas de uma nação, alcançando toda a população. Segundo Sônia Sterman, o Estado não responde pelos referidos danos, uma vez que decorrem de estado de necessidade, que se configura em excludente de responsabilidade ${ }^{183}$. Opondo-se a esse

${ }^{183}$ STERMAN, Sônia. Responsabilidade do Estado. 2. ed. São Paulo: Revista dos Tribunais, 2011. p.189. 
entendimento, Diógenes Gasparini ${ }^{184}$ entende que o Estado responde objetivamente tanto por atos de guerra quanto atos terroristas, reportando-se, para justificar sua posição, ao disposto na Medida Provisória n ${ }^{\circ} 126$ de 2003, convolada na Lei $n^{0}$ 10.744, de 9 de outubro de 2003, que dispõe sobre a assunção, pela União, de responsabilidades civis perante terceiros no caso de atentados terroristas, atos de guerra ou eventos correlatos, contra aeronaves de matrícula brasileira operadas por empresas brasileiras de transporte aéreo público, excluídas as empresas de táxi aéreo.

A Constituição Federal vigente dispõe, no artigo 21, inciso II, que a declaração de guerra e a celebração da paz são de competência da União e se processam por atos do Presidente da República, nos termos do artigo 84, incisos XIX e XX, mediante autorização do Congresso Nacional (art. 49, inciso II), ouvido o Conselho de Defesa Nacional (art. 91,§ $1^{\circ}$ ).

Quanto à análise da hipótese de responsabilização do Estado por danos resultantes de fatos revolucionários, primeiramente é necessário entender o conceito de movimento revolucionário.

Revolução é movimento político organizado que visa a modificar a ordem vigente. A natureza de revolução está atrelada à prática de atos dos comandos militares em rebelião, que causam danos à propriedade, ou à própria integridade física dos administrados, sem a participação de particulares ${ }^{185}$.

Quanto ao dever do Estado de indenizar danos causados por manifestações revolucionárias, queda-se fundado na reparação de lesões resultantes de atos praticados por agentes do Poder Público no comando de forças militares, no exercício da missão pública em defesa da ordem, da legalidade e das instituições públicas.

Os movimentos revolucionários e a orientação dos tribunais brasileiros sobre o tema foram registrados, inicialmente, nas obras de José de Aguiar Dias ${ }^{186}$ e José Cretella Júnior $^{187}$, lastreados nas lições de Pedro Lessa, apontando com riqueza de detalhes vários casos que ilustram tais lições, tais como: O bombardeio de Manaus (1.910); A revolta da Armada (1.910); O bombardeio de Salvador (1.912); O levante do Forte de Copacabana (1.922); A Revolta de Isidoro Dias Lopes (1.924); A Primeira Revolução Constitucionalista (1.930); A Segunda Revolução Constitucionalista (1.932), entre outros.

\footnotetext{
${ }^{184}$ GASPARINI, Diógenes. Direito Administrativo. 17. ed. São Paulo: Saraiva, 2012. p. 1145.

${ }^{185}$ STERMAN, Sônia. Responsabilidade do Estado. 2. ed. São Paulo: Revista dos Tribunais, 2011. p. 191.

${ }^{186}$ DIAS, José Aguiar. Da Responsabilidade Civil. 12. ed.Rio de Janeiro: Lumen Juris, 2011. p. 679.

${ }^{187}$ CRETELLA JR., José. O Estado e a Obrigação de Indenizar. 2. ed. Rio de Janeiro: Forense, 2002,p. 201-210.
} 
No que se refere aos atos de terrorismo praticados por indivíduos movidos pela crueldade atroz, como bem descreve José Cretella Neto ${ }^{188}$, "sociopatas, perdedores, frustrados e fracassados", comungamos das brilhantes lições registradas em obra de sua lavra, que traduzem com clareza solar que "não será jamais suficientemente enfatizado que o terrorismo é um crime abominável, que merece ser chamado pelo nome, jamais glorificado".

Esses indivíduos (os terroristas), sob o argumento de alcançar a glória por meio do martírio, em uma equivocada interpretação fundamentalista da religião, praticam verdadeiras atrocidades, atingindo pessoas inocentes e que nada tem a ver com sua ira contra o mundo em que vivem.

O tema ganhou maior destaque após o atentado de 11 de setembro de 2.011, que atingiu torres gêmeas do World Trade Center, em Nova Iorque e o edifício do Pentágono, em Washington. Os Estados Unidos criaram uma legislação especial para o combate ao terrorismo (USA Patriot Act, de 2.011, prorrogado até 2.015).

Apesar disso, a bibliografia que versa sobre esse assunto é extremamente escassa. José Cretella Neto, reconhecendo a importância do estudo acerca dos aspectos que permeiam as questões relacionadas ao terrorismo, elaborou profunda pesquisa, trazendo à luz feições inéditas, após cotejar centenas de obras e documentos oficiais internacionais, enriquecendo sobremaneira a literatura jurídica pátria.

Analisando mais detidamente o tema, surge o problema de verificar se seria possível ao Estado evitá-lo, tendo em vista, não só o fator surpresa como também a multiplicidade de meios que a imaginação tortuosa do homem tem inventado, como bombas enviadas por carta, pó com bactérias mortais e a guerra bacteriológica realizada por meio de guerrilhas rurais e urbanas. Diante dessa realidade, fica fácil para o Estado eximir-se de responsabilidade, invocando a força maior pela inevitabilidade da possibilidade de fazer frustrar ou minimizar os efeitos de atos terroristas.

\subsubsection{Danos nucleares}

A Constituição Federal de 1.988, no dispositivo contido no art. 21, inciso XXIII, atribui à União competência exclusiva para a exploração dos serviços e instalações nucleares

\footnotetext{
${ }^{188}$ CRETELLA NETO, José. Terrorismo Internacional: Inimigo sem rosto - Combatente sem pátria. Campinas: Millenium, 2008.
} 
de qualquer natureza e o monopólio da pesquisa, da lavra do enriquecimento e reprocessamento, da industrialização e do comércio de minerais nucleares e seus derivados. A alínea "c" deste mesmo inciso determina a responsabilidade civil por danos nucleares independentemente da existência de culpa (responsabilidade objetiva), o que, ao nosso ver, era desnecessário, uma vez que o $\S 6^{\circ}$, do art. 37, já prevê que a reparação de danos decorrentes de qualquer atividade estatal há que recair sobre o Estado.

A Lei $\mathrm{n}^{\circ}$ 6.453, de 17 de outubro de 1.977, dispõe sobre a responsabilidade civil por danos nucleares e a responsabilidade criminal por atos relacionados com atividades nucleares.

O Decreto $n^{\circ}$ 911, de 3 de setembro de 1.993, promulgou a Convenção de Viena sobre Responsabilidade Civil por Danos Nucleares, de 21/05/1.963, determinando o cumprimento integral como nela se contém.

Tal medida considerou que a Convenção de Viena sobre Responsabilidade Civil por Danos Nucleares, concluída em Viena, em 21 de maio de 1.963, sob a égide da Agência Internacional de Energia Atômica (AIEA), entrou em vigor internacional em 12 de novembro de 1977.

O Congresso Nacional aprovou a Convenção, por meio do Decreto Legislativo ${ }^{\circ}$ 93, de 23 de dezembro de 1992, e o governo brasileiro depositou a Carta de Adesão ao instrumento em epígrafe em 23 de março de 1.993, tendo em vista que a referida Convenção entrou em vigor, para o Brasil, em 23 de junho de 1993.

\subsection{DA REPARAÇÃO DO DANO}

Para que o dano seja passível de reparação há de ser certo, atual e subsistente. O prejuízo deve ser revestido de certeza, impedindo-se a indenização por algo fantasioso e que só existe na imaginação da vítima.

Entretanto esta certeza diz respeito à existência do dano, ainda que não seja presente; meras conjecturas afastam a certeza do dano. A lesão tem que ser real, e não cabe indenização por mero perigo ou simples ameaça.

Quando se trata de dano certo, geralmente está-se referindo ao dano já produzido. Contudo pode também haver um dano futuro, que muito embora não tenha ocorrido tem-se a 
certeza de sua ocorrência. Este, no entanto, não é passível de reparação, sendo qualificado como dano eventual ou hipotético.

De um lado temos o dano certo e indenizável, de outro temos o dano eventual ou hipotético que não suporta reparação; entre um e outro, encontramos uma zona neutra em que se coloca o que vem sendo denominado "perda da chance".

A "perda da chance" pode ser traduzida como a frustração de um direito futuro; não se trata de mera probabilidade, mas sim na certeza da impossibilidade de ganho provável. Nessa situação, o dano não é certo, mas o prejuízo também não é eventual nem impossível. Um exemplo bastante ilustrativo é o caso de acidente automobilístico resultando na invalidez de jovem estudante saudável, impossibilitando ou limitando a sua capacidade laborativa.

Nesse sentido, vale destacar as considerações de Antonio Jeová Santos ${ }^{189}$ :

Os direitos são atributos, faculdades e liberdades que se reconhecem e são
outorgados aos indivíduos que compõem a população do Estado. Alguns
deles decorrem da própria natureza do ser humano e o direito apenas o
positiva. Não nascem do Texto Constitucional, porque preexistentes e
imanentes ao homem. O ser humano goza de direitos fundamentais, que
tornam-se positivos, não porque o legislador assim o quis, ao inscrevê-los na
Constituição, mas porque o caráter de tais direitos alude necessariamente à
condição humana e à estrutura da vida.

O ideal é que a reparação ocorra in natura, com a reposição da coisa lesionada ao estado anterior. Esta seria a maneira adequada de ressarcimento. Em tema de direitos personalíssimos, tal não ocorre. Impossível haver a reparação da perda de uma vida ou da honra vergastada. O pagamento de uma soma em dinheiro, nesses casos, serve apenas para compensar o mal infligido, porque não há retorno ao statu quo ante.

O ressarcimento em dinheiro constitui a forma tradicional de indenização. Quando a reparação é integral (quase impossível nos casos em que houver ofensa a direitos da personalidade), satisfaz o credor, colocando fim, em definitivo, à demanda que lhe deu origem. No caso de indenização por dano moral, o pagamento em dinheiro serve apenas como um lenitivo. A perda de um braço, por exemplo, ainda que seja sofisticada a prótese que substitua o membro, jamais colocará fim ao padecimento e diminuição do ofendido. Este, com o montante em dinheiro, terá possibilidade de usufruir alguns prazeres compensatórios, como a possibilidade de se dedicar a uma atividade de lazer antes impossível pela falta de $\operatorname{recursos}^{190}$.

\footnotetext{
${ }^{189}$ SANTOS, Antonio Jeová. Dano Moral Indenizável. 2. ed. São Paulo: Lejus, 1999. p. 57-58.

${ }^{190}$ Idem, Ibidem. p. 29-30.
} 
Os Tribunais brasileiros repudiam a suposição de não responsabilização por prejuízos causados ao meio ambiente, pugnando pela reparação integral na hipótese de dano ambiental, mormente aqueles danos originados da omissão administrativa, consistente em falha na execução do serviço público, da qual resultou o evento ambiental danoso, conforme se verifica no julgado proferido pelo Superior Tribunal de Justiça, nos autos do Recurso Especial 647.493, a seguir transcrito:

RECURSO ESPECIAL. AÇÃO CIVIL PÚBLICA. POLUIÇÃO AMBIENTAL. EMPRESAS MINERADORAS. CARVÃO MINERAL. ESTADO DE SANTA CATARINA. REPARAÇÃO. RESPONSABILIDADE DO ESTADO POR OMISSÃO. RESPONSABILIDADE SOLIDÁRIA. RESPONSABILIDADE SUBSIDIÁRIA.

1. A responsabilidade civil do Estado por omissão é subjetiva, mesmo em se tratando de responsabilidade por dano ao meio ambiente, uma vez que a ilicitude no comportamento omissivo é aferida sob a perspectiva de que deveria o Estado ter agido conforme estabelece a lei.

2. A União tem o dever de fiscalizar as atividades concernentes à extração mineral, de forma que elas sejam equalizadas à conservação ambiental. Esta obrigatoriedade foi alçada à categoria constitucional, encontrando-se inscrita no artigo 225, $\S \S 1^{\circ}, 2^{\circ} \mathrm{e} 3^{\circ}$ da Carta Magna.

3. Condenada a União à reparação de danos ambientais, é certo que a sociedade mediatamente estará arcando com os custos de tal reparação, como se fora autoindenização. Esse desiderato apresenta-se consentâneo com o princípio da equidade, uma vez que a atividade industrial responsável pela degradação ambiental - por gerar divisas para o país e contribuir com percentual significativo de geração de energia, como ocorre com a atividade extrativa mineral - a toda a sociedade beneficia.

4. Havendo mais de um causador de um mesmo dano ambiental, todos respondem solidariamente pela reparação, na forma do art. 942 do Código Civil. De outro lado, se diversos forem os causadores da degradação ocorrida em diferentes locais, ainda que contíguos, não há como atribuir-se a responsabilidade solidária adotando-se apenas o critério geográfico, por falta de nexo causal entre o dano ocorrido em um determinado lugar por atividade poluidora realizada em outro local.

5. A desconsideração da pessoa jurídica consiste na possibilidade de se ignorar a personalidade jurídica autônoma da entidade moral para chamar à responsabilidade seus sócios ou administradores, quando utilizam-na com objetivos fraudulentos ou diversos daqueles para os quais foi constituída. Portanto, (i) na falta do elemento "abuso de direito"; (ii) não se constituindo a personalização social obstáculo ao cumprimento da obrigação de reparação ambiental; e (iii) nem comprovando-se que os sócios ou administradores têm maior poder de solvência que as sociedades, a aplicação da disregard doctrine não tem lugar e pode constituir, na última hipótese, obstáculo ao cumprimento da obrigação.

6. Segundo o que dispõe o art. $3^{\circ}$, IV, c/c o art. 14 , $\S 1^{\circ}$, da Lei n. 6.938/81, os sócios/administradores respondem pelo cumprimento da obrigação de reparação ambiental na qualidade de responsáveis em nome próprio. A responsabilidade será solidária com os entes administrados, na modalidade subsidiária.

7. A ação de reparação/recuperação ambiental é imprescritível. 
8. Recursos de Companhia Siderúrgica Nacional, Carbonífera CriciúmaS/A, Carbonífera Metropolitana S/A, Carbonífera Barro Branco S/A,Carbonífera Palermo Ltda., Ibramil - Ibracoque Mineração Ltda. não-conhecidos. Recurso da União provido em parte. Recursos de Coque Catarinense Ltda., Companhia Brasileira Carbonífera de Ararangua (massa falida), Companhia Carbonífera Catarinense, Companhia Carbonífera Urussanga providos em parte. Recurso do Ministério Público provido em parte. Processo: REsp 647493 SC 2004/0032785-4. Relator (a):Ministro JOÃO OTÁVIO DE NORONHA. Julgamento: 22/05/2007. Órgão Julgador: T2 - SEGUNDA TURMA. Publicação: DJ 22/10/2007 p. 233.

\subsection{DA INDENIZAÇÃ̃}

Em primeiro lugar é importante esclarecer que nem todo dano é indenizável. Somente renderá ensejo à reparação, a lesão que, cumulativamente: a) amesquinhar direito subjetivo ou interesse juridicamente protegido (revelando-se um dano jurídico); b) for economicamente relevante; c) for certo e determinado, ainda que sua projeção seja futura; d) for especial; e ainda, e) for anormal - sendo que os dois últimos requisitos estão presentes apenas nos danos lícitos indenizáveis ${ }^{191}$.

É certo que o Estado, ou quem lhe faça as vezes, seja colocado na contingência de indenizar o particular, e é imprescindível que sua ação ou omissão tenham deflagrado o surgimento de um dano indenizável.

Nos dizeres de Alexandre de Moraes ${ }^{192}$ :

[...] a indenização do dano deve abranger o que a vítima efetivamente perdeu, o que despendeu, o que deixou de ganhar em consequência direta e imediata do ato lesivo do Poder Público, ou seja, deverá ser indenizada nos danos emergentes e nos lucros cessantes, bem como honorários advocatícios, correção monetária e juros de mora, se houver atraso no pagamento. Além disso, nos termos do art. $5^{\circ}, \mathrm{V}$, da Constituição vigente, será possível a indenização por danos morais.

\footnotetext{
${ }^{191}$ Nesse sentido: ZUCKON, Maurício. In: Responsabilidade Patrimonial do Estado. São Paulo: Malheiros, 2010. p. 121.

${ }^{192}$ MORAES. Alexandre. Constituição do Brasil Interpretada e Legislação Constitucional. 7. ed. São Paulo: Atlas, 2007. p. 896
} 
Segundo José Carlos Moreira Alves ${ }^{193}$,

No direito pré-clássico, por força da Lei das XII Tábuas, se se tratava de furtum nec manifestum $\left(^{*}\right)$ concedia-se à vítima ação para que obtivesse a condenação do réu no dobro do valor da coisa furtada. [...] A vítima do furtum dispunha de duas espécies de ações: $a$ ) a ação penal (que tendia à condenação do ladrão a uma pena pecuniária) e; $b$ ) ação reipersecutória (que se destinava à recuperação da coisa, ou à obtenção do equivalente em dinheiro). Essas duas espécies de ação poderiam ser intentadas simultaneamente.

O constitucionalismo moderno incorporou, em suas normas escritas, o que vem a ser conhecido como declarações, direitos e garantias. As declarações dizem respeito à Nação, enquanto a sociedade politicamente organizada, naquilo que diz respeito às demais pessoas da terra. Está afinada com a Nação em si mesma, considerada como organização política, as autoridades em geral e os estados-membros e municípios, enquanto integrantes do Estado. Os direitos são os que correspondem ao efetivo exercício de todo homem e que a Constituição reconhece, sanciona ou concede. As garantias, a seu turno, são todas aquelas seguranças e promessas que a Constituição oferece ao povo brasileiro e a todos os homens. Há uma promessa de que os direitos, tanto os gerais como os especiais, serão sustentados e defendidos pelas autoridades, como também por qualquer outro integrante do povo ${ }^{194}$.

Quanto ao dever do ofensor de indenizar e o direito da vítima à indenização, todo aquele que cause dano a alguém tem obrigação de indenizar e no que diz respeito ao Estado não poderia ser diferente.

Nesse sentido é de grande aproveitamento o ensinamento de Cesare Beccaria ${ }^{195}$ :

Se cada cidadão tem obrigações a cumprir para com a sociedade, a sociedade tem, igualmente obrigações a cumprir para com cada cidadão, pois a natureza do contrato consiste em obrigar igualmente as duas partes contratantes. Esse liame de obrigações mútuas que desce do trono até a cabana e que liga igualmente o maior e o menor dos membros da sociedade tem como fim único o interesse público, que consiste na observação das convenções úteis à maioria. Violada uma dessas convenções, abre-se a porta

${ }^{193}$ MOREIRA ALVES, José Carlos. Direito Romano. vol. II. 4. ed. Rio de Janeiro: Forense, 1986. p. 273-274.

(*) Furto não manifesto é aquele em que o ladrão, tendo-se apoderado clandestinamente da coisa, é descoberto sem a utilização da perquisitio lance licioque (busca a que a vítima do furto procedia na casa do suspeito como ladrão, trajando ela, apenas, um pequeno calção que lhe cobria a parte inferior do tronco, e tendo nas mãos um prato, ritual antiquíssimo e que, no tempo de GAIO, já se figurava ridículo). Idem. p. 269.

${ }^{194}$ SANTOS. Antonio Jeová. Dano Moral Indenizável. 2. ed. São Paulo: LEJUS, 1999. p. 57.

${ }^{195}$ BECCARIA. Cesare. Dos Delitos e Das Penas. Tradução de José Cretella Jr e Agnes Cretella. 3. ed. São Paulo: Revista dos Tribunais, 2006. p. 26. 
à desordem. A palavra obrigação é uma das que se empregam mais frequentemente em moral do que em qualquer outra ciência. Existem obrigações a cumprir no comércio e na sociedade. Uma obrigação supõe um raciocínio moral, convenções raciocinadas. Não se pode, porém, emprestar à palavra obrigação uma ideia física ou real. É palavra abstrata que precisa ser explicada. Ninguém pode obrigar-vos a cumprir obrigações sem saberdes quais são tais obrigações.

Quanto ao valor da indenização, quando se tratar de dano patrimonial, o quantum pode ser apurado mediante a produção de provas documentais, e mesmo os lucros cessantes, pois possível aferir quanto a vítima deixará de auferir em virtude da ocorrência do dano. Já o dano moral é mais difícil, pois na fixação da indenização por danos morais, seu valor não pode ser tão grande que venha a promover o enriquecimento indevido para o autor e nem tão insignificante que não venha a atribuir um caráter punitivo ao réu.

\subsection{DENUNCIAÇÃO DA LIDE}

A expressão denunciação da lide provém do latim denuntiatio litis. A denunciação da lide é um instituto processual que permite, concomitantemente, um ajuste entre a pretensão principal e a regressiva. Há algumas controvérsias sobre o tema, que é passível de grande debate doutrinário.

Alexandre de Moraes ${ }^{196}$ entende que não há obrigatoriedade da denunciação da lide, pois a teoria do risco administrativo, constitucionalmente consagrada, não exige demonstração de dolo ou culpa por parte do agente, mostrando-se incabível e processualmente inadequado discutir-se a responsabilidade subjetiva, que não excluirá a responsabilidade do Estado.

Importante lembrar que o artigo 122, parágrafo $2^{\circ}$, da Lei 8.112/90, afasta a possibilidade de denunciação da lide ao dispor que "tratando-se de dano causado a terceiros, responderá o servidor perante a Fazenda Pública, em ação regressiva”.

Neste diapasão convém atentar para as observações de José Maria Pinheiro Madeira:

${ }^{196}$ MORAES. Alexandre. Constituição do Brasil Interpretada e Legislação Constitucional. 7. ed. São Paulo: Atlas, 2007. p. 904. 
Registre-se que os processualistas admitem a denunciação à lide nesse caso, o que não é pacífico no Direito Administrativo, mas ao contrário, a maioria da doutrina entende inadmissível com correto argumento que tal fato trata o injusto encargo à vítima, pois o Estado, ao denunciar à lide, que tem como fundamento a economia processual, chamará ao processo o seu devedor, e em face da morosidade que se dá nos processos em que este figura, o sujeito lesado demorará mais tempo para ser ressarcido do que seria na ação comum. Da mesma forma, não se justifica que o lesado tenha que esperar a solução de outro litígio para ter o seu atendido ${ }^{197}$.

Para Yussef Said Cahali,

[...] a identificação dos sujeitos que devem integrar o pólo passivo da ação indenizatória, para saber se a demanda pode ser proposta contra o Estado e o agente em litisconsórcio facultativo possível, se deve ser proposta apenas contra o Estado ou se pode ser proposta apenas contra o agente, e se seria admissível, em qualquer caso, a denunciação recíproca da lide, deve ser examinada necessariamente a partir de uma distinção fundamental, que decorre do art. $37, \S 6^{\circ}$, da Constituição ${ }^{198}$.

Também repudiam a hipótese de denunciação à lide, Celso Antônio Bandeira de Mello ${ }^{199}$, reformulando seu posicionamento para acompanhar Weida Zancaner ${ }^{200}$.

A Carta Magna de 1.988 assegura que os sujeitos passivos, na reparação de danos, são as pessoas jurídicas de Direito Público e as de Direito Privado prestadoras de Serviços Públicos. Nesse sentido Celso Ribeiro Bastos ${ }^{201}$ ressalta que não pode haver denunciação da lide, já que isso se traduziria em compelir o agente a participar da própria ação de indenização.

Para Maria Sylvia Zanella Di Pietro ${ }^{202}$, as razões pelas quais a denunciação da lide é incabível estão pautadas nos seguintes pressupostos:

a) são diversos os fundamentos da responsabilidade do Estado e do servidor; b) essa diversidade de tratamento retardaria injustificadamente a solução do conflito, pois, se estaria, com a denunciação à lide, introduzindo outra lide no bojo da lide entre a vítima e o Estado; c) o inciso III do artigo 70 do CPC

\footnotetext{
${ }^{197}$ MADEIRA, José Maria Pinheiro. Administração Pública. TOMO II. 11. ed. Rio de Janeiro: Elsevier, 2009. p. 285.

${ }^{198}$ CAHALI, Yussef Said. Responsabilidade Civil do Estado. 3. ed. São Paulo: Revista dos Tribunais, 2007. p. 151.

${ }^{199}$ BANDEIRA DE MELlO. Celso Antônio. Curso de Direito Administrativo. 28. ed. São Paulo: Malheiros, 2011. p. 1050.

${ }^{200}$ BRUNINI, Weida Zancaner. Da responsabilidade extracontratual da administração pública. São Paulo: Revista dos Tribunais, 1981. p. 64-65.

${ }^{201}$ BASTOS, Celso Ribeiro. Curso de Direito Administrativo. São Paulo: Saraiva, 1994. p. 187.

${ }^{202}$ DI PIETRO, Maria Sylvia Zanella. Direito administrativo. 24. ed. São Paulo: Atlas, 2011. p. 665.
} 
refere-se ao garante, o que não inclui o servidor, no caso da ação regressiva prevista no dispositivo constitucional.

Odete Medauar ${ }^{203}$, reforçando os argumentos daqueles que são contrários à denunciação da lide, observa que:

a) a $\mathrm{CF}$, art. $37, \S 6^{\circ}$, responsabiliza o Estado pelo ressarcimento à vítima do dano, com base na prova do nexo causal; aqui se trata de relação de responsabilidade entre poder público e vítima (ou cônjuge e herdeiros), descabida a interferência de outra relação obrigacional; portanto, o art. 70, III, do Código de Processo Civil deixa de prevalecer ante a regra constitucional; b) necessidade de priorizar o direito da vítima, evitando demora no andamento do processo pelo ingresso de mais um sujeito; c) ingerência de um fundamento novo na demanda principal.

Não obstante reine dissenso tanto na doutrina quanto na jurisprudência no sentido de repudiar a denunciação da lide, há argumentos favoráveis à denunciação, pelo seguinte: a) o art. 70, III, do CPC alcança todos os casos de ação regressiva; b) por economia processual e para evitar decisões conflitantes a responsabilidade do agente pode ser apurada nos autos da ação de reparação de dano; c) recusar a denunciação da lide do agente cerceia um direito da Administração ${ }^{204}$.

Também perfilhando a corrente adversa à denunciação da lide, Edmir Netto de Araújo $^{205}$ sustenta que:

Se está denunciando à lide, no caso de ação promovida contra si por responsabilidade civil objetiva, estará confessando a lide, pois está reconhecendo que um agente seu causou um prejuízo injusto a particular, por dolo ou culpa; e se no sistema constitucional o dolo e a culpa do servidor (art. 37, § $6^{\circ}$ da $\mathrm{CF}$ ) não eximem o Estado da responsabilidade (na verdade é exatamente o oposto), a Fazenda Pública, com essa confissão, não pode contestar a ação contra si intentada. Está, também, no mínimo, ignorando o princípio da indisponibilidade do interesse público, ao transigir em uma ação, a priori, sem que se verifique a probabilidade do seu fracasso judicial. $\mathrm{O}$ advogado do prejudicado, em nosso entender, poderia nesse caso requerer o julgamento no estado do processo.

Isto quer dizer, em outros termos, que, se o Estado denuncia à lide, tal situação configura sem dúvida uma confissão antecipada, uma presunção de que o agente agiu com dolo ou culpa.

\footnotetext{
${ }^{203}$ MEDAUAR, Odete. Direito administrativo moderno. 16. ed. São Paulo: Revista dos Tribunais, 2012. p. 408.

${ }^{204}$ MEDAUAR, Odete. Direito administrativo moderno. 16. ed. São Paulo: Revista dos Tribunais, 2012.

${ }^{205}$ ARAÚJO, Edmir Netto de. Curso de Direito Administrativo. 5.ed. São Paulo: Saraiva, 2010. p. 801.
} 
Edmir Netto de Araújo esclarece, ainda, que quando o prejuízo é causado pelo servidor, agindo nessa qualidade, ao particular, o regime de responsabilidade para a composição do dano é o da responsabilidade do Estado, com a regressividade contra o servidor, nos termos do artigo 37, $\S 6^{\circ}$, da Constituição Federal vigente. Modernamente, o problema da responsabilidade do Estado por atos ou omissões prejudiciais de seus agentes, ou por fatos e coisas à sua guarda, é equacionado em termos eminentemente objetivos, sendo o administrado dispensado do ônus probante quanto à culpabilidade direta ou indireta $d a$ Administração. Pelo contrário, presentes todos os elementos para a responsabilização (dano, vítima, sujeito ativo agente público no exercício de suas funções, causa com referibilidade ao Estado), esta Administração é que estará obrigada a comprovar, caso queira eximir-se integral ou parcialmente da obrigatoriedade de reparar o dano, que ocorre em qualquer das hipóteses excludentes ou atenuantes de responsabilidade, para isso examinando especialmente a causa, que é o elemento catalisador dos danos mencionados ${ }^{206}$.

Posicionou-se muito bem Márcia Andréa Bühring ${ }^{207}$, para quem o artigo 70, III, do Código de Processo Civil, ainda que afirme ser a denunciação da lide obrigatória, tal dispositivo torna-se inócuo, visto a Carta Magna assegurar ação de regresso independente de denunciação. Por isso - complementa a autora - não cabe a medida, eis que a Constituição Federal vislumbrou a mais ampla reparação ao cidadão pelos prejuízos causados pela ação do Poder Público, que ficaria comprometida no tempo da denunciação.

A denunciação da lide é dispensável e até mesmo inoportuna, uma vez que a regra do art. 70, inciso III, do Código de Processo Civil não encontra aplicação nos casos de responsabilidade objetiva, e, além disso, esse dispositivo do CPC deixa de prevalecer diante da regra constitucional.

Lúcia Vale Figueiredo ${ }^{208}$ argumenta que a denunciação da lide, com fundamento no art. 70, III, do CPC, é restrita àquele que ostenta a condição de garante, não podendo ser confundido com o agente público, cuja responsabilidade ainda será posteriormente aferida. A mesma autora entende, também, que o funcionário não pode ser acionado diretamente se a vítima pretender apenas provar o dano e a relação de causalidade com o Estado (por

\footnotetext{
${ }^{206}$ ARAÚJO, Edmir Netto de. O ilícito administrativo e seu processo. São Paulo: Revista dos Tribunais, 1994. p. 266.

${ }^{207}$ BÜHRING, Márcia Andréa. Responsabilidade Civil Extracontratual do Estado. São Paulo: Thopson-IOB, 2004. p. 183.

${ }^{208}$ FIGUEREDO, Lúcia Vale. Curso de Direito Administrativo. 7. ed. São Paulo: Malheiros, 2004. p. 278.
} 
conseguinte objetivamente). Somente se a ação proposta tiver fundamento na culpa ou dolo do funcionário será este parte legítima.

Sendo o agente público acionado quando o lesado vislumbrar apenas provar o dano e a relação de causalidade com o Estado - cuja responsabilidade é de índole objetiva, sem necessidade de demonstração de culpa -, haverá inquestionavelmente a ilegitimidade de parte do agente público.

Nesse sentido é o posicionamento do Supremo Tribunal Federal:

RECURSO EXTRAORDINÁRIO. ADMINISTRATIVO. RESPONSABILIDADE OBJETIVA DO ESTADO: $\S 6^{\circ}$ DO ART. 37 DA MAGNA CARTA. ILEGITIMIDADE PASSIVA AD CAUSAM. AGENTE PÚBLICO (EX-PREFEITO). Prática de ato próprio da função. Decreto de intervenção. O $\S 6^{\circ}$ do artigo 37 da Magna Carta autoriza a proposição de que somente as pessoas jurídicas de direito público, ou as pessoas jurídicas de direito privado que prestem serviços públicos, é que poderão responder, objetivamente, pela reparação de danos a terceiros. Isto por ato ou omissão dos respectivos agentes, agindo estes na qualidade de agentes públicos, e não como pessoas comuns. Esse mesmo dispositivo constitucional consagra, ainda, dupla garantia: uma, em favor do particular, possibilitando-lhe ação indenizatória contra a pessoa jurídica de direito público, ou de direito privado que preste serviço público, dado que bem maior, praticamente certa, a possibilidade de pagamento do dano objetivamente sofrido. Outra garantia, no entanto, em prol do servidor estatal, que somente responde administrativa e civilmente perante a pessoa jurídica a cujo quadro funcional se vincular. Recurso extraordinário a que se nega provimento ${ }^{209}$.

RECURSO EXTRAORDINÁRIO. RESPONSABILIDADE OBJETIVA. AÇÃO REPARATÓRIA DE DANO POR ATO ILÍCITO. ILEGITIMIDADE DE PARTE PASSIVA. 2. RESPONSABILIDADE EXCLUSIVA DO ESTADO. A autoridade judiciária não tem responsabilidade civil pelos atos jurisdicionais praticados. Os magistrados enquadram-se na espécie agente político, investidos para o exercício de atribuições constitucionais, sendo dotados de plena liberdade funcional no desempenho de suas funções, com prerrogativas próprias e legislação específica. 3. Ação que deveria ter sido ajuizada contra a Fazenda Estadual responsável eventual pelos alegados danos causados pela autoridade judicial, ao exercer suas atribuições -, a qual, posteriormente, terá assegurado o direito de regresso contra o magistrado responsável, nas hipóteses de dolo ou culpa. 4. Legitimidade passiva reservada ao Estado. Ausência de responsabilidade concorrente em face dos eventuais prejuízos causados a terceiros pela autoridade julgadora no exercício de suas funções, a teor do art. 37, § $6^{\circ}$, da CF/88. 5. Recurso extraordinário conhecido e provido ${ }^{210}$.

Portanto, é a denunciação da lide uma das formas de intervenção de terceiros em que o denunciante, acautelando-se contra a possibilidade de condenação, chama o causador do

\footnotetext{
${ }^{209}$ RE 327.904-1/SP, Rel .Min. Carlos Britto; $1^{\mathrm{a}} \mathrm{T}$; j. 15.08.2006.

${ }^{210}$ RE 228977/SP; $2^{\mathrm{a}}$ Turma do STF; Rel. Min. Néri da Silveira; j. 05/03/2002.
} 
dano para juntar-se a ele, a fim de também integrar o polo passivo. Entretanto, pelos inconvenientes que provoca - já apontados no decorrer dessas considerações, não comporta seu manejo nas hipóteses de processos em que se discute a responsabilidade do Estado.

\subsection{AÇÃO REGRESSIVA CONTRA O CAUSADOR DO DANO}

A Constituição Federal vigente autoriza a interposição de ação regressiva contra o causador do dano, nas hipóteses de culpa ou dolo. O artigo 37 , § $6^{\circ}$, da $\mathrm{CF} / 88$ assegura o direito de regresso em face do responsável nos casos em que seja constatada a presença de dolo ou culpa. No entanto, não será caso de regresso quando o agente causador do dano ou concorrente para esse evento danoso não tenha participado com dolo ou culpa, assim como também não for possível identificar o agente culpado, nas hipóteses de falta ou deficiência do serviço ou de sua prestação tardia: nessas circunstâncias, o ônus é tão somente da Administração.

O artigo 194 da Constituição de 1.946 já prescrevia que:

[...] as pessoas jurídicas de direito público interno são civilmente responsáveis pelos danos que os seus funcionários, nessa qualidade, causarem a terceiros.

Parágrafo único. Caber-lhes-á ação regressiva contra os funcionários causadores do dano, quando tiver havido culpa deles.

De acordo com os ensinamentos de Edmir Netto de Araujo ${ }^{211}$, a culpabilidade ou o dolo do agente, na omissão ou prática do ato prejudicial, somente será apurada para que, em caso positivo, promova o Estado a ação regressiva a que se refere o $\S 6^{\circ}$ do art. 37 da Constituição Federal de 1988, contra o causador do dano em espécie, e esta ação constitui obrigação do Estado, em virtude do princípio da indisponibilidade dos interesses públicos. E mesmo que a Constituição Federal atual não mencionasse, a ação regressiva contra o agente causador do dano seria cabível nos termos do artigo 934 do Código Civil.

Conforme esclarece Márcia Andréa Bühring ${ }^{212}$, até determinada época, sobrevinha uma discordância no que se refere ao direito ou dever de regresso, apontado no artigo 37, $\S 6^{\circ}$, da Carta Magna atual, mas, atualmente, a questão está totalmente pacificada,

\footnotetext{
${ }^{211}$ ARAÚJO, Edmir Netto de. O ilícito administrativo e seu processo. São Paulo: Revista dos Tribunais, 1994. p. 800..

${ }^{212}$ BÜHRING, Márcia Andréa. Responsabilidade Civil Extracontratual do Estado. São Paulo: Thopson-IOB, 2004. p. 173.
} 
uma vez que o Poder Público é obrigado a intentar ação regressiva, naqueles casos em que fica comprovada a culpa ou o dolo de seus agentes, nas hipóteses de danos causados, ainda que o texto constitucional assevere "assegurado o direito de regresso contra o responsável".

Para Hely Lopes Meirelles ${ }^{213}$, a ação regressiva movida pela administração contra o agente causador da lesão está preconizada no $\S 6^{\circ}$ do art. 37 , da $\mathrm{CF} / 88$ como mandamento a todas as entidades públicas e particulares prestadoras de serviços públicos. Para o êxito dessa ação, exigem-se dois requisitos: primeiro, que a Administração já tenha sido condenada a indenizar a vítima do dano sofrido; segundo, que se comprove a culpa do funcionário no evento danoso. Enquanto para a Administração a responsabilidade independe de culpa, para o agente a responsabilidade está diretamente vinculada à culpa; aquela é objetiva, esta é subjetiva e se apura pelos critérios gerais do Código Civil.

Diógenes Gasparini ${ }^{214}$ ressalta que o direito de regresso não prescreve, conforme preconiza o $\S 5^{\circ}$, do art. 37, da Carta Magna. A ação de regresso poderá ser ajuizada em face do agente causador do dano e, na falta, contra seus herdeiros ou sucessores, dado que obrigação meramente patrimonial. Ademais, pode ser intentada após o afastamento (exoneração, demissão, disponibilidade, aposentadoria) do agente causador do dano de seu cargo, emprego, ou função pública.

O Estado tem o dever de ajuizar uma ação regressiva, nas hipóteses em que se provar a culpa ou o dolo de seus agentes, nos casos de danos efetivamente consumados. $\mathrm{O}$ direito de regresso é imperativo para o ente público, em homenagem ao princípio da indisponibilidade do interesse público ${ }^{215}$.

Márcia Andréa Bühring ${ }^{216}$ assevera que "Depois que a vítima é indenizada, o Estado deve recompor seu patrimônio que foi desfalcado à custa dos bens do agente causador do dano, visto estar a ação regressiva expressamente autorizada, conforme o enunciado constitucional".

\footnotetext{
${ }^{213}$ MEIRELLES, Hely Lopes. Direito Administrativo Brasileiro. 37. ed., atualizada por Eurico Andrade Azevedo, Décio Balestero Aleixo e José Emmanuel Burle Filho. São Paulo: Malheiros, $2011 . p .710$.

${ }^{214}$ GASPARINI. Diógenes. Direito Administrativo. 17. ed. São Paulo: Saraiva, 2012.

${ }^{215}$ FIGUEIREDO, Lúcia Valle. Curso de Direito Administrativo. 7. ed. São Paulo: Malheiros, 2.004. p. 291.

${ }^{216}$ BÜHRING. Márcia Andréa. Responsabilidade Civil Extracontratual do Estado. São Paulo: Thompson-IOB, 2004. p. 175 .
} 
Nessa mesma toada, José Maria Pinheiro Madeira ${ }^{217}$ afirma que

O direito de regresso é admissível no Direito Administrativo, pois o agente estatal que cometeu um dano a terceiro terá que ressarcir ao Estado aquilo que ele já pagou ao particular que foi lesado. Há controvérsia na doutrina no que tange à existência ou não de prazo prescricional na ação de regresso, prevalecendo o entendimento de que não há prazo imprescritível ${ }^{218}$.

Segundo Élcio Trujillo ${ }^{219}$, no que diz respeito aos danos decorrentes de atividades lícitas, o Estado responde com exclusividade perante a vítima. Entretanto, quanto às lesões decorrentes de práticas ilícitas, o Estado tem o direito-dever de exercitar o direito de regresso em face ao agente que praticou a ilicitude, recompondo o erário público.

O artigo $37, \S 6^{\circ}$ assegura o direito de regresso contra o responsável nos casos de dolo ou culpa, ou seja, estar-se-ia referindo ao agente público que culposa ou dolosamente praticou o ato sancionável. Em tese, não há que se falar em direito de regresso, quando o agente, agindo no estrito cumprimento do dever legal, causa dano a terceiros. Neste caso, separa-se o ato lícito do ato ilícito pelo direito de regresso.

É também o entendimento do Tribunal de Justiça de São Paulo:

INDENIZAÇÃO. RESPONSABILIDADE CIVIL. MAGISTRADO. DOLO NO EXERCÍCIO DA ATIVIDADE JURISDICIONAL. LITISCONSÓRCIO PASSIVO NECESSÁRIO COM O ESTADO. INADMISSIBILIDADE. Hipótese em que somente este pode voltar-se contra o juiz em ação regressiva. Ilegitimidade passiva "ad causam". Recurso não provido. - "Só o Estado poderá voltar-se contra o Magistrado, comprovado o dolo no exercício da atividade jurisdicional, para ressarcir-se do que pagou à parte que suportou o dano" (TJSP $-2^{\mathrm{a}} \mathrm{C}$. Dir. Público - Ap. Rel. Vanderci Álvares -j. 10.09.1996 - JTJ-LEX 186/94).

\subsection{A PRESCRIÇÃO}

O princípio da prescrição de direitos garante a segurança jurídica das relações. De acordo com o antigo adágio jurídico - $\mathrm{O}$ direito não socorre os que dormem - assim, também, com qualquer outro direito, no caso de reparação de danos causados por exercício de atividade estatal, também há que se aplicar a referida regra.

\footnotetext{
${ }^{217}$ MADEIRA, José Maria Pinheiro. Administração Pública. TOMO II. 11.ed. Rio de Janeiro: Elsevier, 2010. p. 284.

${ }^{219}$ TRUJILLO, Elcio. Responsabilidade do Estado por Atos Lícitos. São Paulo: LED Editora de Direito, 1997.
} 
A Lei federal $\mathrm{n}^{\circ}$ 9.494, de 10 de setembro de 1.997 disciplina a aplicação da tutela antecipada contra a Fazenda Pública. O prazo prescricional para propor ação judicial buscando indenização por danos, cuja responsabilidade é imputada ao Estado, é de 5 (cinco) anos contados a partir da data da ocorrência do fato danoso, nos termos do artigo $1^{\circ}$ do Decreto 20.910/32, in verbis:

Art. $1^{\circ}$ As dívidas passivas da União, dos Estados e dos Municípios, bem assim todo e qualquer direito ou ação contra a Fazenda federal, estadual ou municipal, seja qual for a sua natureza, prescrevem em cinco anos contados da data do ato ou fato do qual se originarem.

Importante destacar que o instituto da prescrição, assim como a decadência, militam em favor da segurança jurídica, ou seja, garantem a estabilidade das relações jurídicas, por meio da eliminação do estado de potencial modificação que pesa sobre elas. A prescrição representa a perda da ação que protege o direito, enquanto a decadência representa a perda do próprio direito. Tanto uma quanto outra deflagram o transcurso do tempo qualificado pela conduta omissiva do titular do direito ${ }^{220}$.

No que tange ao direito administrativo, têm-se, de um lado, as pretensões do administrado diante a Administração, por via administrativa ou judicial, e, de outro giro, o exercício do dever-poder (função) da administração, por si ou pela via judicial, perante o administrado.

O artigo 178, § 10, inciso VI do Código Civil Brasileiro de 1.916, possuía a mesma redação do artigo $1^{\circ}$ do Decreto 20.910/32, entretanto o referido dispositivo não encontrou correspondência no novo Código Civil Brasileiro de 2.002, razão pela qual o referido Decreto continua sendo a base legal para aplicação da prescrição nos casos de indenização reclamada contra o Estado.

Também a jurisprudência aponta para esse entendimento, conforme mencionado por Alexandre de Moraes $^{221}$ :

Prescrição quinquenal: STJ - "Prescrição - Decreto $\mathrm{n}^{\circ}$ 20.910/32. 1. Prescreve em cinco anos, contados da ocorrência do ato ou fato, a ação contra a fazenda estadual para haver indenização por responsabilidade civil do Estado. 2. Não pode vingar a ação indenizatória proposta depois de cinco anos do evento causador da morte do filho da autora" (STJ $-2^{\mathrm{a}} \mathrm{T}$. - Resp. $\mathrm{n}^{\circ}$ 20.860-2/SP - Rel. Min. Peçanha Martins. Ementário STJ, nº 9/627).

\footnotetext{
${ }^{220}$ VALIM, Rafael. O Princípio da Segurança Jurídica no Direito Administrativo. São Paulo: Malheiros, 2010. p. 131.

${ }^{221}$ MORAES. Alexandre. Constituição do Brasil Interpretada e Legislação Constitucional. 7. ed. São Paulo: Atlas, 2007. p. 909-910.
} 
E, ainda, com relação ao início da contagem do prazo:

Início da contagem do prazo prescricional: STJ - "AdministrativoResponsabilidade civil do Estado - CF/88, art. 37, § $6^{\circ}$ - Hospital público Vírus HIV - Contaminação - Transfusão sanguínea - Prescrição quinquenal - Não ocorrência - Decreto 20.910/32, art. 1º, Administrativo. Responsabilidade civil do Estado (art. 37, § 6 , CF). Contaminação pelo vírus HIV. Hospital público (transfusão sanguínea). Prescrição quinquenal inocorrente. Decreto Federal 20.910/32 (art. $1^{\circ}$ ). 1. O fato vértice para a contagem do prazo quinquenal (art. $1^{\circ}$, Dec. Fed. 20.910/32), no caso, fincase na data do conhecimento do resultado revelado pelo exame técnico laboratorial e não de causa externa anterior, desconhecida pelo destinatário da transfusão de sangue (HIV). Em contrário pensar, seria a revolta do direito contra a realidade dos fatos, homenageando-se compreensão ilógica de prévio conhecimento pelo destinatário e voluntária aceitação de transfusão fatal com sangue contaminado" (STJ - $1^{\mathrm{a}} \mathrm{T}$. - Resp. ${ }^{\circ} 140.158-$ 0/SC - Rel. Min. Milton Luiz Pereira. RSTJ 102/127).

"ADMINISTRATIVO - PROCESSUAL CIVIL - AÇÃO DE INDENIZAÇÃO POR DANOS MORAIS E MATERIAIS - PRESCRIÇÃO QUINQUENAL - FAZENDA PÚBLICA - INTELIGÊNCIA DO ART. $1^{\circ}$ DO DECRETO N. . 20.910/32 - MANUTENÇÃO DA SENTENÇA. 1 Cuidando-se de ação de indenização ajuizada contra o Estado, o prazo prescricional previsto no Decreto n. ${ }^{\circ} 20.910$, de $06 / 01 / 32$, que é a legislação especial reguladora da prescrição nas relações jurídicas em que a Fazenda Pública é devedora, prepondera sobre aquele estabelecido no Código Civil. 2 - Em consequência, se a ação foi proposta mais de cinco anos após a prática do ilícito atribuída ao Estado, encontra-se prescrita a pretensão do autor de haver indenização por danos materiais e morais. 3 - Recurso não-provido. APELAÇÃO CÍVEL N ${ }^{\circ}$ 1.0611.06.018647-9/001 - COMARCA DE SÃO FRANCISCO - APELANTE(S): ELI CARLOS QUEIROZ DA SILVA APELADO(A)(S): ESTADO MINAS GERAIS, MUNICÍPIO SÃO FRANCISCO - RELATOR: EXMO. SR. DES. EDGARD PENNA AMORIM. Número do processo: 1.0611.06.018647-9/001(1), Numeração Única: 0186479-70.2006.8.13.0611, julgamento 19/02/2009, publicação 20/05/2009.

No que diz respeito às Sociedades de Economia Mista, prescreve em 20 anos a ação para haver indenização, por responsabilidade civil, nos termos da Súmula 39 do STJ.

No caso das Autarquias e entidades e órgãos paraestatais, o artigo $2^{\circ}$ do Decreto-

Lei n ${ }^{\circ} 4.597 / 42$, estende a aplicação do Decreto 20.910, nos seguintes termos:

Art. $2^{\circ}$ - O Decreto $\mathrm{n}^{\circ} 20.910$, de 6 de janeiro de 1932, que regula a prescrição quinquenal, abrange as dívidas passivas das autarquias, ou entidades e órgãos paraestatais, criados por lei e mantidos mediante impostos, taxas ou quaisquer contribuições, exigidas em virtude de lei federal, estadual ou municipal, bem como a todo e qualquer direito e ação contra os mesmos (grifo nosso). 


\section{Conclusão}

Neste segundo capítulo, buscou-se primeiramente trazer à lume o papel do Estado, em linhas gerais; em seguida empreendeu-se a tentativa de focalizar a responsabilidade do Estado pela omissão, e as consequências que a conduta omissiva pode acarretar, suscitando o problema do conceito de faute de service, importado da doutrina francesa, mas que pela tradução equivocada provoca, ainda, entre os doutrinadores confusão na conceituação do instituto, sendo causa de divergência tanto doutrinária quanto jurisprudencial.

Para verificar se há omissão danosa ou como se refere Juarez de Freitas - omissão desproporcional -, aquela passível de reparação, deve-se verificar se a omissão estatal é socialmente benéfica ou se se trata de omissão que negligencia os mecanismos para obtenção eficaz e razoável dos fins colimados pela Administração, ou, ainda, se a omissão é necessária ou se refere à abstenção da prática do ato que impõe sacrifícios iníquos e inaceitáveis na distribuição dos encargos.

Também consideramos importante, nesse estudo, distinguir a responsabilidade do Agente Público daquela imputada ao Estado, pois o agente público, sendo a pessoa jurídica que presta serviços ao Estado e às pessoas jurídicas da Administração indireta - pode, no exercício de suas funções ou em razão desse exercício, praticar atos ilícitos nas esferas civil, penal e administrativa.

Nesse contexto, destacou-se a responsabilidade inominada do Estado decorrente de variações climáticas, movimentos sociais e multitudinários.

A fim de proporcionar uma visão generalizada da questão que envolve a Responsabilidade Estatal, pontuamos alguns aspectos relativos à reparação do dano, e pontuamos a denunciação da lide, sem deixar de fazer menção à obrigação do Estado em exercitar o direito de regresso contra o agente causador do dano e, por fim, fazendo referência ao instituto da prescrição.

Diante de todos os argumentos esposados e do panorama geral apresentado, nosso posicionamento é no sentido de que, nos casos de comportamento omissivo que causarem danos a terceiros, ocorra a aplicação da Teoria Objetiva, na modalidade de Risco Administrativo, considerando a necessidade de proteger-se a vítima ante a dificuldade desta em demonstrar a culpa ou o dolo do agente público, ou que o serviço não funcionou, funcionou mal, ou funcionou tardiamente. Ademais, a doutrina que sustenta a teoria subjetiva, mostra-se muito frágil. Além disso, o artigo 43 do Código Civil de 2.002, corroborando a 
norma constitucional, estabelece que há que se falar em culpa apenas na hipótese de ação regressiva movida pelo Estado face ao agente causador do dano. 


\section{PRINCÍPIO DA PREVENÇÃO E DA PRECAUÇÃO APLICADO À RESPONSABILIDADE DO ESTADO POR OMISSÃ̃O}

\subsection{DEFINIÇÃO E CLASSIFICAÇÃO DE PRINCÍPIOS}

A origem da palavra "princípio" reside no vernáculo grego; na língua latina principium, pode ser traduzido como aquilo que ocupa o primeiro lugar. Todas as áreas do saber estão consolidadas sobre princípios, porque se referem às proposições básicas, fundamentais e típicas, que vinculam as edificações subsequentes de determinada ciência.

Nicola Abbagnano ${ }^{1}$ adverte que, em Matemática e Lógica, esse termo está em desuso quando se trata de indicar as premissas de um discurso, sendo substituído por axioma ou postulado. Nestas áreas do saber, é comum denominar, de princípios, teoremas particulares cuja importância para o desenvolvimento posterior de um sistema se queira ressaltar.

O significado de princípio no sentido de ponto de partida, fundamento ou causa foi introduzido por Anaximandro ${ }^{2}$. Platão ${ }^{3}$ também recorria ao conceito de princípio quando referia-se à causa do movimento ou, ainda, ao fundamento da demonstração ${ }^{4}$.

Aristóteles ${ }^{5}$, considerado o fundador da lógica formal, foi o primeiro a sistematizar os significados para princípio, conforme se observa:

$1^{\circ}$ ) Ponto de partida de um movimento, por exemplo, de uma linha ou de um caminho;

\footnotetext{
${ }^{1}$ ABBAGNANO, Nicola. Dicionário de Filosofia. São Paulo: Martins Fontes, 2007. p. 929.

${ }^{2}$ ANAXIMANDRO foi um filósofo grego pré-Socrático que, seguindo a escola jônica, viveu entre 610 a.C. e 547 a.C. Além de filósofo, era também geógrafo, matemático, astrônomo, político e discípulo de Tales. Seguiu a escola jônica.
}

${ }^{3}$ PLATÃO era filósofo em Atenas, cidade onde nasceu e viveu entre 428 a.C. e 348 a.C., e também onde fundou a Academia, a primeira instituição de ensino superior do ocidente. Era discípulo de Sócrates e teve como pupilo Aristóteles. Platão possuía grande capacidade intelectual, para tratar de temas como ética, política, metafísica e teoria do conhecimento.

\footnotetext{
${ }^{4}$ ABBAGNANO, Nicola. Dicionário de Filosofia. São Paulo: Martins Fontes, 2007. p. 928.

${ }^{5}$ ARISTÓTELES foi um filósofo grego, aluno de Platão e professor de Alexandre, o Grande, nascido em Estagira, 384 a.C. Faleceu em Atenas em 322 a.C. Seus escritos abrangem diversos assuntos, como a física, a metafísica, as leis da poesia e do drama, a música, a lógica, a retórica, o governo, a ética, a biologia e a zoologia. Juntamente com Platão e Sócrates, Aristóteles é visto como um dos fundadores da filosofia ocidental. Em 343 a.C. tornou-se tutor de Alexandre da Macedónia, na época com 13 anos de idade, que foi o mais célebre conquistador do mundo antigo. Em 335 a.C. Alexandre assume o trono e Aristóteles volta para Atenas, onde funda o Liceu (lyceum) em 335 a.C.
} 
$2^{\circ}$ ) O melhor ponto de partida, ou aquilo que facilita aprender uma coisa;

$3^{\text {o }) ~ P o n t o ~ d e ~ p a r t i d a ~ e f e t i v o ~ d e ~ u m a ~ p r o d u c ̧ a ̃ o, ~ c o m o ~ a ~ q u i l h a ~ d e ~ u m ~ n a v i o ~ o u ~ o s ~}$ alicerces de uma casa;

$4^{\circ}$ ) Causa externa de um processo ou de um movimento, como um insulto que provoca uma briga;

$\left.5^{\circ}\right) \mathrm{O}$ que, com a decisão, determina movimentos ou mudanças, como o governo ou as magistraturas de uma cidade;

$6^{\circ}$ ) Aquilo de que parte um processo de conhecimento, como por exemplo as premissas de uma demonstração.

O Dicionário Houaiss de Língua Portuguesa apregoa que:

Princípio. s.m. 1. o primeiro momento da existência (de algo), ou de uma ação ou processo; começo, início [...]. 2. O que serve de base a alguma coisa; a causa primeira, raiz, razão. 3. Ditame moral; regra, lei, preceito. 5. Proposição elementar e fundamental que serve de base a uma ordem de conhecimento.

A definição adotada por Celso Antônio Bandeira de Mello $^{6}$ informa que:

Princípio é, pois, por definição, mandamento nuclear de um sistema, verdadeiro alicerce dele, disposição fundamental que irradia sobre diferentes normas, compondo-lhes o espírito e servindo de critério para exata compreensão e inteligência delas, exatamente porque define a lógica e a racionalidade do sistema normativo, conferindo-lhe a tônica que lhe dá sentido harmônico.

De acordo com Luis-Diez Picazo ${ }^{7}$, a noção de princípio deriva da linguagem da geometria, "onde designa as verdades primeiras" e, precisamente por essa razão, são "princípios", isto é, "porque estão ao princípio", são verdades objetivas, nem sempre pertencentes ao mundo do ser, senão do dever-ser, na qualidade de normas jurídicas, dotadas de vigência, validez e obrigatoriedade.

Paulo Bonavides ${ }^{8}$, referindo-se ao conceito de princípio suscitado pela Corte Constitucional Italiana, cita a sentença proferida em 1.956, nos seguintes termos:

\footnotetext{
${ }^{6}$ BANDEIRA DE MELLO, Celso Antônio. Curso de direito administrativo. 28. ed. revista, atualizada e ampliada. São Paulo: Malheiros. 2011. p. 54.

${ }^{7}$ PICAZO, Luis-Diez. Los princípios generales del derecho em el pensamento de F. de Castro. In: Anuario de Derecho Civil, t. XXXVI, fasc.3ㅇ, out/dez 1983, pp. 1267-1268, apud BONAVIDES, Paulo. Curso de Direito Constitucional. 13. ed. São Paulo: Malheiros, 2003. p. 255-256.
}

${ }^{8}$ BONAVIDES, Paulo. Curso de Direito Constitucional. 13. ed. São Paulo: Malheiros, 2003. p. 256. 
Faz-se mister assinalar que se devem considerar como princípios do ordenamento jurídico aquelas orientações e aquelas diretivas de caráter geral e fundamental que se possam deduzir da conexão sistemática, da coordenação e da íntima racionalidade das normas, que concorrem para formar, assim, num dado momento histórico, o tecido do ordenamento jurídico.

O estudo dos princípios é objeto da principiologia, ciência que identifica, conceitua e classifica os princípios e estende minuciosa investigação acerca do tema, ou seja, sistematiza racionalmente os princípios. De modo genérico, princípio é o ponto inicial, a pedra angular ou aquilo que serve de base a partir da qual se ergue ou edifica um estudo que segue evoluindo, ou ainda, premissa utilizada como base a uma ordem de conhecimentos.

Todas as áreas do conhecimento estão sedimentadas sobre "princípios" próprios, que servem de viga mestra na construção daquela área específica. Assim, há vários critérios para classificá-los, e de acordo com o que se busque destacar, como por exemplo, o aspecto temporal, lógico, ético, sociológico, religioso, e assim por diante.

Para a dissertação aqui desenvolvida, elegemos a classificação baseada no critério da abrangência, utilizada por José Cretella Neto ${ }^{9}$ em obra sobre a principiologia do processo civil, mas que pode perfeitamente ser aplicada à análise aqui proposta. Pelo critério da abrangência, os princípios podem ser classificados como onivalentes ou universais, plurivalentes e setoriais.

Onivalentes ou universais são aqueles que podem ser aplicados, indistintamente, a todas as ciências, pois se constituem em princípios racionais do pensamento. As modalidades de princípios onivalentes são:

- princípio da identidade, segundo o qual, no decorrer do raciocínio, um termo somente pode representar um conceito único e específico, não se confundindo com nenhum outro. Ex.: A Terra é redonda.

- princípio da não-contradição, aquele que estabelece que duas ideias contraditórias não podem ser, ao mesmo tempo, verdadeiras, nem simultaneamente falsas. Dois atributos diametralmente opostos são mutuamente excludentes. Ex.: O mar é azul e verde.

- princípio do terceiro excluído - estabelece que havendo duas proposições conflitantes, se uma delas for verdadeira, a outra será, necessariamente, falsa, e reciprocamente, inexistindo uma terceira solução.

\footnotetext{
${ }^{9}$ CRETELLA NETO, José. Fundamentos Principiológicos do Processo Civil. Rio de Janeiro: Forense, 2002,.p. 5-9.
} 
- princípio da razão suficiente - apregoa que nada existe sem uma causa, ou seja, sem uma razão que explique o porquê dessa existência ou acontecimento.

Plurivalentes são aqueles princípios comuns a mais de uma ciência, ou a um grupo de ciências, orientando-as apenas nos aspectos em que se interpenetrem (alterum non laedere).

Setoriais são princípios considerados como proposições básicas nos quais repousam os diversos setores em que se baseia determinada ciência. No Direito Administrativo, um exemplo claro de princípio setorial é o princípio da especialidade, segundo o qual toda pessoa jurídica pública descentralizada, como as autarquias, deve desempenhar suas atividades, perseguindo o objeto específico para o qual foi constituída. Ou seja, as pessoas jurídicas públicas administrativas devem empregar os recursos humanos, materiais e técnicos para a consecução do fim específico, em virtude do qual foram criadas.

\subsection{PRINCÍPIOS GERAIS DE DIREITO}

Princípios gerais de direito são premissas básicas, normas de caráter geral com papel fundamental no desenvolvimento de uma teoria e das quais outras normas podem ser derivadas. Têm por finalidade nortear a marcha investigativa do estudioso do direito. Além disso, servem, ainda, como fonte para o julgador direcionar a solução das demandas submetidas à sua apreciação, quando a lei ou a jurisprudência não conseguem dar conta dessa empreitada.

De acordo com Irene Patrícia Nohara ${ }^{10}$, "Princípios são normas jurídicas de caráter geral e elevada carga valorativa". Até a metade do século XX, os princípios foram tidos como pertencentes ao mais baixo grau de hierarquização das fontes de direito, ou seja, fontes secundárias e meramente supletivas das situações de lacuna normativa.

Os princípios gerais de direito são fontes de aplicação da ciência jurídica que, como normas, têm caráter vinculante, cogente ou obrigatório, na proporção em que se configuram em destacada expressão do consenso social acerca de valores básicos a serem assegurados no Estado Democrático.

\footnotetext{
${ }^{10}$ NOHARA, Irene Patrícia. Direito Administrativo. São Paulo: Atlas, 2011. p. 53.
} 
Em posição contrária, Osvaldo Aranha Bandeira de Mello ${ }^{11}$ considerava os princípios gerais de direito ladeados à analogia, à doutrina e à equidade como "modos" e aplicação do direito.

Clóvis Beviláqua ${ }^{12}$ entendia que:

[...] princípios gerais de Direito são os elementos fundamentais da cultura jurídica humana em nossos dias.

Dentre esses princípios, podem ser citados os seguintes:

. ninguém pode transferir mais direitos do que possui;

. ninguém deve ser condenado sem ser ouvido

. ninguém pode invocar a própria malícia, para beneficiar-se;

. quem exercita o próprio direito não causa prejuízo a ninguém;

. o contrato faz lei entre as partes;

. ato praticado com vício de origem, não se convalida com o decorrer do tempo.

Os Princípios Gerais do Direito são as bases fundamentais da ciência jurídica, que lhe servem de apoio e coerência, sustentando o ideal de Justiça que permeia o Direito. São premissas fundantes de caráter geral dentro de cada área de atuação do Direito.

Convém destacar que, embora a expressão "Princípios Gerais do Direito" conduza à ideia de postulados genéricos, essa mesma expressão vai abranger tanto os princípios gerais quanto os específicos relativos a um determinado ramo da ciência jurídica. Tais princípios têm dupla função, uma vez que orientam tanto o legislador na elaboração das normas, quanto o aplicador do direito, diante de uma lacuna ou omissão legal. Por possuir caráter essencialmente amplo, o aplicador do Direito, bem como o legislador, que neles se baseiam, devem ter cautela e limites para a atuação, sob pena de incorrer em incoerência na solução para uma determinada situação.

A Lei de Introdução ao Código Civil, em seu artigo $4^{\circ}$, recomenda ao juiz que no caso de omissão da lei, este recorra à analogia. Caso essa não resolva a questão, que sejam verificados os usos e costumes do local. Entretanto, se mesmo assim, a situação não for solucionada, o juiz lançará mão dos Princípios Gerais do Direito.

Para Genaro Carrió ${ }^{13}$ há diversos sentidos possíveis para o conceito de princípios, dentre os quais: a) parte ou ingrediente importante de algo, núcleo básico ou, ainda,

\footnotetext{
${ }^{11}$ BANDEIRA DE MELlO, Osvaldo Aranha. Princípios Gerais de Direito Administrativo. vol. I. 3. ed. São Paulo: Malheiros, 2007. p. 234.

${ }^{12}$ BEVILAQUA. Clóvis. Código Civil dos Estados Unidos do Brasil. Vol. I. 7. ed. Rio de Janeiro: Livraria ed. Francisco Alves, 1944. p. 16 apud CRETELLA NETO, José. Fundamentos Principiológicos do Processo Civil. Rio de Janeiro: Forense, 2002. p. 14.
} 
característica central; b) regra, guia, orientação ou indicações gerais; c) fonte geradora, causa ou origem; d) finalidade, objetivo, propósito ou meta; e) premissa, ponto de partida, verdade teórica postulada como evidente ou essência; f) regra prática de conteúdo evidente e verdade ética inquestionável; e ainda g) uma máxima.

Robert Alexy e Ronald Dworkin, em estudo sobre a configuração das normas jurídicas, admitem a divisão em duas categorias: os princípios e as regras ${ }^{14}$. A contribuição destes notáveis pós-positivistas proporcionou a reaproximação da ética com o Direito. Superando as doutrinas positivistas, Alexy e Dworkin defenderam a inclusão de um novo tipo de norma no ordenamento jurídico, as chamadas normas princípio, que juntamente com as normas regras regulariam as condutas.

\subsection{DISTINÇÃO ENTRE NORMAS, PRINCÍPIOS E REGRAS}

Tanto regras quanto princípios são espécies do gênero normas, e ambos dizem o que deve ser formulado por meio das expressões deônticas básicas do dever, da permissão ou da proibição. Há diversos critérios para estabelecer diferenças entre regras e princípios. ${ }^{15}$

De acordo com Robert Alexy ${ }^{16}$, o critério mais utilizado para estabelecer a diferença entre regra e princípio é o critério da generalidade, segundo o qual regras são normas com grau de generalidade mais baixo, enquanto princípios são normas com grau de generalidade mais alto.

Ronald Dworkin ${ }^{17}$ afirmava que regras, sendo válidas, devem ser aplicadas de forma tudo-ou-nada; por outro lado os princípios somente conteriam elementos que indicam uma direção, mas não têm como consequências necessárias uma determinada decisão.

\footnotetext{
${ }^{13}$ CARRIÓ, Genaro. Princípios Jurídicos e Positivismo Jurídico. Buenos Aires,:Abeledo-Perrot, 1970. p. 34-38 apud ZOCKUN. Maurício. Responsabilidade Patrimonial do Estado. São Paulo: Malheiros, 2010. p. 85.

${ }^{14}$ CARVALHO FILHO, José dos Santos. Manual de Direito Administrativo. 25.ed. São Paulo: Atlas. 2012. p. 19.

${ }^{15}$ ALEXY, Robert. Teoria dos Direitos Fundamentais. Tradução Virgílio Afonso da Silva. 2.ed. São Paulo: Malheiros, 2011. p. 87.

${ }^{16}$ Idem, Ibidem. p. 87.

17 DWORKIN, Ronald. Taking Rights Seriously. p. 24 e 26. In: ALEXY, Robert. Teoria dos Direitos Fundamentais. Tradução Virgílio Afonso da Silva. 2.ed. São Paulo: Malheiros, 2011. p. 104.
} 
Alexy ${ }^{18}$, por suas reflexões, demonstra que princípios e regras são razões de naturezas distintas. Ambos podem ser considerados como razões para as ações ou razões para as normas; Princípios são sempre razões prima facie, e estão intimamente ligados ao conceito de valores, e Regras são, se não houver estabelecimento de alguma exceção, razões definitivas.

Atualmente, os princípios, cuja observância é obrigatória e vinculante, ocupam lugar de grande destaque no cenário jurídico, mas não foi sempre assim. Durante a vigência da teoria positivista, os princípios estavam adstritos à aplicação supletiva e ocupavam o papel de meros coadjuvantes.

A teoria normativa dos princípios é tema que guarda íntima relação com o póspositivismo. A distinção entre princípios e regras é o ponto principal do pós-positivismo, fruto da influência exercida por Ronald Dworkin e Robert Alexy, cujos pensamentos encontram-se amplamente divulgados no Brasil por Paulo Bonavides, Luis Roberto Barroso entre outros. Ao analisarmos o contexto jurídico brasileiro atual, conforme o já citado artigo $4^{\circ}$ da Lei de Introdução do Código Civil, encontramos a tradicional hierarquia das fontes do direito: "Quando a lei for omissa, o juiz decidirá o caso de acordo com a analogia, os costumes e os princípios gerais de direito”. Por aí, se observa que os princípios se posicionam em último lugar, na categoria de fonte subsidiária do direito, cuja aplicação só se justifica na falta de lei ou de costume, assim como na impossibilidade de aplicação da analogia. Entretanto, com o surgimento do pós-positivismo, os princípios assumiram o posto de fonte de alta envergadura.

Segundo Paulo Bonavides ${ }^{19}$, a juridicidade dos princípios passa por três distintas fases:

i) a jusnaturalista: cuida-se da fase mais antiga, na qual os princípios habitavam ainda em uma esfera por inteiro abstrata e detinham normatividade por demais duvidosa, mais se ajustando,em verdade, a uma dimensão meramente ético-valorativa que inspirava postulados de justiça; ii) a juspositivista: aqui os princípios adentram nos Códigos, tornando-se inequivocamente jurídicos, porém apenas como fonte normativa subsidiária, o que lhe castrou a normatividade; iii) pós-positivista: corresponde aos grandes momentos constituintes das últimas décadas do século XX, onde se acentua a hegemonia axiológica dos princípios, tratados verdadeiramente como direito, com força vinculante e tudo, convertidos que foram em

\footnotetext{
${ }^{18}$ ALEXY, Robert. Teoria dos Direitos Fundamentais. Tradução Virgílio Afonso da Silva. 2.ed. São Paulo: Malheiros, 2011. p. 106-107.

${ }^{19}$ BONAVIDES, Paulo. Curso de Direito Constitucional. 19. ed. São Paulo: Malheiros, 2006. p. 259-266.
} 
pedestal normativo sobre o qual assenta todo o edifício jurídico dos novos sistemas constitucionais.

O fenômeno do pós-positivismo surge, na modernidade, conforme assevera Luís Roberto Barroso $^{20}$, como um novo caminho que se descortina, no momento em que "o direito está em crise" e o positivismo vive uma crise existencial. Na sua percepção, "a injustiça passeia pelas ruas com passos firmes e a insegurança é a característica da nossa era”, e declara com segurança que:

O pós-positivismo é a designação provisória e genérica de um ideário difuso, no qual se incluem a definição das relações entre valores, princípios e regras, aspectos da chamada nova hermenêutica e a teoria dos direitos fundamentais. [...] O Direito, a partir da segunda metade do século XX, já não cabia mais no positivismo jurídico. A aproximação quase absoluta entre Direito e norma e sua rígida separação da ética não correspondiam ao estágio do processo civilizatório e às ambições dos que patrocinavam a causa da humanidade. Por outro lado, o discurso científico impregnara o Direito. Seus operadores não desejavam o retorno puro e simples ao jusnaturalismo, aos fundamentos vagos, abstratos ou metafísicos de uma razão subjetiva. Nesse contexto, o pós-positivismo não surge com o ímpeto da desconstrução, mas como uma superação do conhecimento convencional. Ele inicia sua trajetória guardando deferência relativa ao ordenamento positivo, mas nele reintroduzindo as ideias de justiça e legitimidade. O constitucionalismo moderno promove, assim, uma volta aos valores, uma reaproximação entre ética e Direito ${ }^{21}$.

As reflexões feitas por Paulo Bonavides ${ }^{22}$ nos mostram com clareza a complexidade do tema em questão, conforme se depreende do seguinte trecho:

É na idade do pós-positivismo que tanto a Doutrina do Direito Natural como a do velho positivismo ortodoxo vêm abaixo, sofrendo golpes profundos e crítica lacerante, provenientes de uma reação intelectual implacável, capitaneada sobretudo por Dworkin, jurista de Harvard. Sua obra tem valiosamente contribuído para traçar e caracterizar o ângulo novo de normatividade definitiva reconhecida aos princípios. [...] A construção doutrinária da normatividade dos princípios provém, em grande parte, do empenho da Filosofia e da Teoria Geral do Direito em buscarem um campo neutro onde se possa superar a antinomia clássica Direito Natural/Direito Positivo. [...] Em resumo, a teoria dos princípios chega à presente fase do

\footnotetext{
${ }^{20}$ BARROSO, Luís Roberto. Neoconstitucionalismo e Constitucionalização do Direito. In: Revista da Escola Nacional da Magistratura. Ano I, n. 02, outubro de 2006, Brasília: Escola Nacional da Magistratura - ENM, p. 26. In: MARANHÃO, Ney Stany Morais. O Fenômeno Pós-Positivista: Considerações Gerais. Disponível em: <http://www.anamatra.org.br/sites/1200/1223/00001573.pdf>. Acesso em: 17 dez. 2012.

${ }^{21}$ BARROSO, Luis Roberto. Fundamentos Teóricos e Filosóficos do Novo Direito Constitucional Brasileiro (Pós-Modernidade, Teoria Crítica e Pós-Positivismo). In: BARROSO, Luis Roberto (org.). A Nova Interpretação Constitucional: Ponderação, Direitos Fundamentais e Relações Privadas. 2. ed. Rio de Janeiro: Renovar, 2006. p. 27-28.
}

${ }^{22}$ BONAVIDES, Paulo. Curso de Direito Constitucional. 19. ed. São Paulo: Malheiros, 2006. p. 265-276, 294. 
pós-positivismo com os seguintes resultados já consolidados: a passagem dos princípios da especulação metafísica e abstrata para o campo concreto e positivo do Direito, com baixíssimo teor de densidade normativa; a transição crucial da ordem jusprivatista (sua antiga inserção nos Códigos) para a órbita juspublicística (seu ingresso nas Constituições); a suspensão da distinção clássica entre princípios e normas; o deslocamento dos princípios da esfera da jusfilosofia para o domínio da Ciência Jurídica; a proclamação de sua normatividade; a perda de seu caráter de normas programáticas; o reconhecimento definitivo de sua positividade e concretude por obra sobretudo das Constituições; a distinção entre regras e princípios, como espécies diversificadas do gênero norma, e, finalmente, por expressão máxima de todo esse desdobramento doutrinário, o mais significativo de seus efeitos: a total hegemonia e preeminência dos princípios.

Toda a tradição do pensamento jurídico ocidental é dominada pela distinção entre "direito positivo" e "direito natural".

Segundo Norberto Bobbio $^{23}$, a expressão “positivismo jurídico" não deriva de "positivismo" em sentido filosófico, embora tenha havido uma ligação entre ambas, posto que alguns positivistas jurídicos eram, também, positivistas no sentido filosófico. Tanto é assim que enquanto o positivismo jurídico surgiu na Alemanha, o positivismo filosófico surgiu na França. O juspositivismo está ligado à crença exacerbada no poder do conhecimento científico.

Ao contrário, para Paulo Nader ${ }^{24}$, “o positivismo jurídico é fiel aos princípios do positivismo filosófico, rejeita todos os elementos de abstração na área do Direito, a começar pela ideia de Direito Natural, por julgá-la metafísica e anticientífica”. O positivismo jurídico se omite em relação a valores, e o direito repousa exclusivamente na lei. Para o positivista, a lei assume a condição de único valor. Há que se destadar que o princípio da obediência incondicional à lei foi responsável pelo surgimento de regimes totalitários como o fascismo, o nazismo e o stalinismo, e deu causa a sua decadência.

A Teoria Pura de Hans Kelsen ${ }^{25}$ situou o Direito na área do dever-ser. Segundo essa percepção, a ordem jurídica estaria disposta em uma estrutura normativa em forma de pirâmide, na qual uma norma está vinculada a outra norma, sucessivamente, e a denominada Norma Fundamental legitimaria toda esta estrutura normativa, que se apresenta de maneira hierarquizada. As normas jurídicas formam uma pirâmide, na qual se tem pela ordem: a Constituição, a lei, a sentença de execução. A Constituição estaria no topo da pirâmide e

\footnotetext{
${ }^{23}$ BOBBIO, Norberto. O Positivismo Jurídico. São Paulo: Ícone, 1999. p. 15.

${ }^{24}$ NADER, Paulo. Introdução ao Estudo do Direito. 19. ed. Rio de Janeiro: Forense, 2000. p. 370.

${ }^{25}$ KELSEN, Hans. Teoria Pura do Direito. 2. ed. revista da tradução de J. Cretella Júnior e Agnes Cretella. São Paulo: Revista dos Tribunais, 2002.
} 
acima dela encontra-se a Norma Fundamental, ou Grande Norma, ou ainda Norma Hipotética, que poderia ser uma Constituição anterior ou uma revolução triunfante ${ }^{26}$. O objeto da ciência do Direito seria apenas o estudo da norma jurídica.

Kelsen admitia como conceito de justiça, a aplicação da norma jurídica ao caso concreto; a sua ideia era de que considerações de ordem valorativa estariam fora da ciência do direito.

Miguel Reale ${ }^{27}$, em 1.968, lançou a teoria de que o fenômeno jurídico só faz sentido com a participação dialética do fato, valor e da norma. Todo fato (evento) possui um valor (aspecto axiológico) e para tal uma determinada norma. Essa teoria ficou mundialmente conhecida como "Teoria Tridimensional", segundo a qual o Direito se define como "realidade histórico-cultural tridimensional, ordenada de forma bilateral atributiva, segundo valores de convivência."

\subsection{PRINCÍPIOS DO DIREITO ADMINISTRATIVO}

"São princípios basilares do Direito Administrativo e do Estado de Direito: a supremacia do interesse público e a legalidade, pois elas conferem o equilíbrio entre a satisfação dos interesses coletivos e as liberdades individuais",28.

Curvando-se à importância dos princípios administrativos, as Constituições brasileiras, em vários momentos, fazem-lhes referência, revelando as bases fundamentais da Administração, de maneira que uma conduta pode ser considerada válida apenas se guardar compatibilidade com esses princípios.

O artigo 37, § 6º da Constituição Federal de 1988 agasalhou cinco princípios do Direito Administrativo: legalidade, impessoalidade, moralidade, publicidade e eficiência (este acrescentado pela EC $\left.{ }^{\circ} 19 / 98\right)$.

Já a Constituição Estadual de São Paulo, além da adoção dos princípios constantes do referido artigo 37, também acrescenta a esse rol os princípios da razoabilidade, finalidade, motivação e interesse público.

\footnotetext{
${ }^{26}$ NADER, Paulo. Introdução ao Estudo do Direito. 19. ed. Rio de Janeiro: Forense, 2000. p. 374.

${ }^{27}$ REALE, Miguel. Teoria Tridimensional do Direito. 5. ed. São Paulo: Saraiva, 1994.

${ }^{28}$ NOHARA, Irene Patrícia. Direito Administrativo. São Paulo: Atlas, 2011. p. 55.
} 
A Lei $n^{\circ}$ 9.784/99 (Lei de Processo Administrativo), no artigo $2^{\circ}$, por sua vez, cuidou dos seguintes princípios: legalidade, finalidade, motivação, razoabilidade, proporcionalidade, moralidade, ampla defesa, contraditório, segurança jurídica, interesse público e eficiência.

José dos Santos Carvalho Filho ${ }^{29}$ adotou nomenclatura diferenciada, ao denominar "expressos" os princípios constitucionais e chamar de "reconhecidos" aqueles aceitos pela doutrina como não constitucionais, definindo-os da seguinte forma:

Princípios administrativos são postulados fundamentais que inspiram todo o modo de agir da Administração Pública. Representam cânones prénormativos, norteando a conduta do Estado quando no exercício de atividades administrativas.

\subsubsection{Princípios constitucionais do Direito Administrativo}

Muitos princípios morais, éticos e jurídicos, por sua excepcional importância, foram convertidos, pelo legislador, em norma constitucional.

Robert Alexy construiu a teoria de princípios e regras pautando-se na classificação formal de direitos fundamentais da Alemanha. No entanto, os direitos fundamentais que compõem o ordenamento jurídico brasileiro estão enfeixados por um critério material.

Alguns princípios estampados no artigo $5^{\circ}$ da atual Constituição da República são, de acordo com a visão de Robert Alexy, simples regras. Isto é, entre nós, os princípios e as regras de Alexy estão no mesmo patamar hierárquico e, por isso, gozam da mesma valência normativa ${ }^{30}$.

Nenhuma das Constituições anteriores havia trazido em seu bojo princípios e preceitos básicos do Direito Administrativo de maneira tão detalhada e completa quanto a atual Constituição Federal, e, conforme os ensinamentos de Paulo Bonavides ${ }^{31}$, "Os princípios, uma vez constitucionalizados, se fazem a chave de todo o sistema normativo".

\footnotetext{
${ }^{29}$ CARVALHO FILHO, José dos Santos. Manual de Direito Administrativo. 25. ed. São Paulo: Atlas. 2012. p. 18-19.

${ }^{30}$ ZOCKUN. Mauricio. Responsabilidade Patrimonial do Estado. São Paulo: Malheiros, 2010. p. 91.

${ }^{31}$ BONAVIDES, Paulo. Curso de Direito Constitucional. 13. ed. São Paulo: Malheiros, 2003. p. 258.
} 
A par disso, é preciso fazer uma distinção entre princípios políticoconstitucionais, indicadores das opções políticas fundamentais, que moldam toda a Carta Magna (exs.: os princípios contidos nos arts. $1^{\circ}$ a $4^{\circ}$ da $\mathrm{CF} / 88$ ) e os princípios jurídicoconstitucionais, que informam toda a ordem jurídica nacional.

Os princípios de interesse, nesta dissertação, são os jurídico-constitucionais, de natureza administrativa.

A Constituição Federal atual prescreve os princípios constitucionais informativos do Direito Administrativo em capítulo próprio, ou seja, aquele dedicado, exclusivamente, à Administração. Também são chamados de Princípios Constitucionais da Administração Pública, Princípios Básicos da Administração, Princípios Constitucionais da Administração ou, ainda, Princípios de Direito Administrativo.

Os princípios constitucionais do Direito Administrativo constam do art. 37, caput, da Constituição Federal de 1.988 e são os seguintes:

- Princípio da legalidade;

- Princípio da impessoalidade;

- Princípio da moralidade;

- Princípio da publicidade; e

- Princípio da eficiência (este último acrescentado pela EC 19/98).

Pelo princípio da legalidade, o administrador público está, em toda a sua atividade funcional, sujeito às determinações legais, não podendo se afastar ou se desviar, sob pena de praticar ato inválido e sujeitar-se à responsabilização disciplinar, civil e criminal, conforme o caso. Considera-se que este seja o princípio mais importante, dentre os citados, pois dele advêm todos os outros, uma vez que, além de indicado nos arts. $5^{\circ}$, II, 37 e 84, IV, da Constituição Federal vigente, assenta-se na própria estrutura do Estado de Direito. Quanto à Administração Pública, esse princípio estabelece que a validade e a eficácia de toda a atividade administrativa estão condicionadas ao atendimento da norma legal.

$\mathrm{Na}$ Administração Pública, não há liberdade nem vontade pessoais. Nas relações jurídicas particulares é lícito fazer tudo o que a lei não proíbe, mas, em via inversa, na Administração Pública, só é permitido fazer o que a lei autoriza.

Quanto ao princípio da moralidade, a Administração Pública e seus agentes devem atuar de acordo com valores éticos, compreendendo em seu âmbito princípios de lealdade e boa-fé. 
A moralidade administrativa constitui pressuposto essencial de validade de todo ato da Administração Pública. Não se trata da moral comum, mas sim de uma moral jurídica, entendida como "o conjunto de regras de conduta tiradas da disciplina interior da Administração". Entende-se que o agente administrativo, como ser humano dotado de capacidade de atuar, deve, necessariamente, distinguir o bem do mal. E, ao atuar, não poderá desprezar o elemento ético de sua conduta. Assim, não terá que decidir somente entre o legal e o ilegal, o justo e o injusto, o conveniente e o inconveniente, o oportuno e o inoportuno, mas também entre o honesto e o desonesto. Por considerações de Direito e de Moral, o ato administrativo não terá que obedecer somente às leis jurídicas, mas também à ética da própria instituição, pois, às vezes, o que é legal não é honesto, conforme já proclamavam os romanos: non omne quod licet honestum est.

A moral comum é imposta ao Homem para sua conduta externa; a moral administrativa é imposta ao agente público para sua conduta interna, segundo as exigências da instituição a que serve e a finalidade de sua ação, que é o bem comum.

Em resumo, a moralidade do ato administrativo juntamente com a sua legalidade e finalidade constituem pressupostos de validade sem os quais toda a atividade pública será ilegítima.

A moralidade administrativa integra o Direito Público como elemento indissociável na sua aplicação e na sua finalidade, erigindo-se em fator de legalidade. Dessa forma, conclui-se que o controle jurisdicional não se restringe somente ao exame da legalidade do ato administrativo, mas por legalidade ou legitimidade entende-se além da conformação do ato com a lei, também com a moral administrativa e com o interesse coletivo.

O princípio da impessoalidade, também acolhido no art. 37, caput, da CF, pode ser tido como indicativo da imparcialidade que condiciona a atividade administrativa a deferir tratamento igual a todos, deve ser levado em conta para excluir a promoção pessoal de autoridades ou servidores públicos sobre suas realizações administrativas; repele tratamento discriminatório ou favoritismo entre os administrados; aniquila hipóteses de perseguições, animosidades pessoais, políticas ou ideológicas, impedindo a interferência de tais condutas na atividade administrativa.

Pelo princípio da publicidade, obriga-se a divulgação oficial do ato para conhecimento público e início de seus efeitos externos. A atuação do Poder Público deve ser transparente, visando proporcionar o controle dos seus atos, contratos ou negócios pelos administrados. 
O referido controle tem fundamento no interesse dos administrados em ter ciência dos assuntos que lhes dizem respeito, possibilitando-lhes a defesa de seus direitos por meios de ações constitucionais, tais como o mandado de segurança e a ação popular.

A publicidade visa inibir a ocultação do exercício funcional do agente público, impossibilitando a prática de conduta reprovável contrária à moralidade administrativa. Além disso, a publicidade abrange todo o universo da Administração Pública, em que eventos das mais variadas modalidades são revestidos de absoluta clareza: atos concluídos e em andamento, pareceres de órgãos técnicos e jurídicos, processos licitatórios (atas de julgamentos e contratos), procedimentos administrativos diversos, comprovação de despesas e prestação de contas.

A publicação que produz efeitos jurídicos é aquela feita pelos órgão oficiais da Administração, e não pela imprensa particular, pela televisão ou pelo rádio, ainda que em horário oficial. Entendem-se como órgãos oficiais, não só o Diário Oficial, mas também as publicações contratadas com essa finalidade.

O princípio da eficiência é aquele que obriga a Administração Pública a empreender todos os esforços necessários e disponíveis para o melhor desempenho de suas atividades.

Este princípio foi introduzido na CF pela Emenda Constitucional $\mathrm{n}^{\mathrm{o}} 19$, de 04.06.1998, mas falar em Administração Pública eficiente parece redundância, pois que a eficiência, mais do que um princípio individualizado consiste em uma obrigação implícita da engrenagem administrativa, subentendendo nesta engrenagem os agentes públicos, os órgãos administrativos e os entes da administração direta e indireta.

A eficiência é, para muitos autores, colocada no rol de "deveres" do Administrador Público, e não no de princípios, como ocorre com a legalidade, a impessoalidade, a publicidade e a moralidade. A verificação da eficiência abrange aspectos quantitativos e qualitativos. A rigor, a eficiência, considerada em sentido amplo, está implícita no princípio da moralidade, pois que a desídia funcional denota certo desvio de conduta, prejudicando não apenas a produtividade, mas a lisura das ações praticadas, comprometendo a credibilidade daqueles que são depositários da confiança dos administrados.

Observam-se as deficiências do serviço público tanto pelos vícios burocráticos quanto pelo excesso de trabalho dos agentes públicos, pela carência de mão de obra especializada, ou simplesmente pela desmotivação do agente, que não vislumbra satisfação pessoal no desempenho de suas funções. 
Muito embora tal princípio tenha sido consagrado pela EC 19/98, na realidade corresponde ao "dever da boa administração" da doutrina italiana, o que já se acha sedimentado entre nós, pela Reforma Administrativa Federal do Decreto no 200/67.

A eficácia na prestação dos serviços públicos, igualmente, vem acompanhada de inúmeros mecanismos constitucionais para sua implementação. Dessa forma, o texto constitucional consagra o princípio da eficiência, a flexibilização do conceito de estabilidade do servidor público e os contratos de gestão.

\subsubsection{Princípios não constitucionais do Direito Administrativo}

Também se revestem de importância outros princípios quando consagrados por normas legais de hierarquia inferior, como ocorre com a Constituição Estadual de São Paulo, que acolhe os seguintes princípios:

- Princípio da razoabilidade;

- Princípio da finalidade;

- Princípio da motivação; e

- Princípio do interesse público.

Outras leis que dispõem sobre a Administração Pública também podem conter princípios informativos do Direito Administrativo. Assim, pode-se, ainda, citar os seguintes princípios, que constituem o chamado regime jurídico-administrativo:

- Princípio da supremacia do interesse público;

- Princípio da continuidade;

- Princípio da indisponibilidade;

- Princípio da autotutela;

- Princípio da especialidade;

- Princípio da presunção de legitimidade;

- Princípio da proporcionalidade;

- Princípio da segurança jurídica;

O princípio da razoabilidade é aquele sedimentado em critérios racionais, e está atrelado às situações postas pela coletividade em determinado momento, levando em conta 
aspectos econômicos, culturais ou sociais, ou seja, valores éticos e morais válidos para toda a coletividade.

Tal princípio visa limitar o poder discricionário do agente público, que poderá praticar determinados atos, com certa margem de liberdade de avaliação ou decisão, segundo critérios de conveniência e oportunidade, desde que não ultrapasse os limites de bom senso, de coerência, de legitimidade, e de economia, sempre visando ao bem comum.

Por essa razão, observa-se que, mesmo quando o exercício da atividade administrativa permite ao agente certa liberdade de agir, ao mesmo tempo, impede que tal liberdade seja desmedida, inconsequente e prejudicial ao interesse público.

O princípio da finalidade estabelece que o objetivo a ser atingido pela prática de determinado ato deve estar determinado na norma legal; não se confunde com o princípio da legalidade, mas é consequência dele.

Todo ato que se apartar desse objetivo sujeitar-se-á à invalidação por desvio de finalidade, que nossa Lei da Ação Popular conceituou como "o fim diverso daquele previsto, explícita ou implicitamente, na regra de competência do agente" (Lei $n^{\circ} 4.717 / 65$, art. $2^{\circ}$, parágrafo único).

O princípio da finalidade exige que o ato seja praticado sempre com o objetivo de preservar o interesse público, que, por vezes, pode coincidir com o interesse de particular, como ocorre, por exemplo, em contratos públicos em que é lícito conjugar o interesse coletivo com o particular.

A lei não concede permissão para agir sem um objetivo; a obrigação jurídica não é uma obrigação inconsequente, pois visa a um fim específico, predetermina um destino, antecipa um alcance.

A ideia é, basicamente, o atrelamento de um fim preestabelecido e que deve ser traduzido, sempre, em benefício da maioria, enquanto provê a segurança do Estado, a manutenção da ordem pública e a satisfação de todas as necessidades da sociedade.

Pelo princípio da motivação, todo ato administrativo deve ser justificado. $\mathrm{O}$ agente público jamais poderá agir de acordo com sua própria vontade, não lhe sendo facultado o livre arbítrio no exercício funcional. Por vezes, a vontade do agente pode coincidir com o interesse coletivo, mas a justificativa ou a motivação deve estar baseada no interesse público, e somente por essa razão a execução do ato será admitida, tornando-o válido, para que produza seus efeitos.

Em Direito Administrativo, deve-se pesquisar o motivo da ação do agente público como centro motriz da vontade, pois, inexistindo o motivo, inválido será o ato administrativo. 
O princípio do interesse público estabelece que os efeitos de determinado ato administrativo devem atender ao bem-estar coletivo, e não ao interesse próprio do agente administrativo.

Quanto ao princípio da supremacia do interesse público, trata-se da sobreposição do interesse coletivo ao individual, isso não significa que o interesse particular deva ser desprezado, pois a superioridade do interesse coletivo não deve desrespeitar o direito do particular ou afrontar lei que o assegure. É princípio geral de Direito em qualquer sociedade. Trata-se de um pressuposto lógico para o convívio social e, muito embora não esteja expresso no art. $37 \mathrm{da} \mathrm{CF}$, pode ser encontrado em vários outros dispositivos que o contemplam.

Exemplo claro é o instituto da desapropriação previsto no art. $5^{\circ}$, XXIV e XXV da $\mathrm{CF}$, em que é patente a sobreposição da conveniência em favor da coletividade sobre o particular. Porém, a norma determina que o particular seja indenizado pela perda do patrimônio. Desta forma, o interesse público é contemplado sem lesar o direito individual.

Pelo Princípio da continuidade, os contratos de serviços firmados entre particular e Administração Pública não podem ser paralisados, pois a atividade administrativa não deve ser interrompida, correndo-se o risco de causar danos à coletividade, ainda que a Administração descumpra cláusula contratual.

No Direito Privado, as partes contratantes encontram-se em condição de igualdade quanto aos direitos e obrigações resultantes da relação jurídica, o que coloca o contrato, quanto à execução, à alteração e às demais condições, em uma sistemática recíproca quase absoluta. Já no regime jurídico de Direito Público, em virtude da aplicação do princípio da supremacia do interesse público sobre o interesse individual, com o Estado em posição de preponderância sobre o particular na relação jurídica, possibilita-se que o mesmo Estado tome certas medidas ou use de certas prerrogativas sem a aquiescência do contratado, embora sejam observadas certas regras jurídicas protetoras do interesse privado e do equilíbrio contratual.

Tratando-se de agentes públicos, certas funções não podem ser paralisadas sob nenhum pretexto, nem mesmo para o exercício de direito constitucional (CF, art. 37, VII). Serviços essenciais não admitem suspensão ou interrupção, como os de segurança pública, transporte público e saúde.

O Princípio da indisponibilidade corresponde à impossibilidade do administrador em concretizar quaisquer transações sem prévia e correspondente norma legal que o autorize. O agente público assume papel de gestor de bens, de pessoal, e de serviços públicos. Exercendo tal gestão, realiza os negócios administrativos segundo a legislação pertinente. 
É dever do agente público zelar por aquilo que lhe é confiado, por serem indisponíveis bens e interesses públicos, uma vez que pertencem e dizem respeito à sociedade.

Em suma, o princípio da indisponibilidade limita a gestão do administrador, proibindo-o de praticar atos que configurem disposição dos bens públicos sem autorização legal.

Em virtude do princípio da autotutela, é facultado à administração reconsiderar seus próprios atos, tanto para revogá-los quanto para anulá-los. A súmula 473 do STF, estabelece que: “A Administração pode anular seus próprios atos, quando eivados dos vícios que os tornem ilegais. Porque deles não se originam direitos; ou revogá-los, por motivo de conveniência e oportunidade, respeitados os direitos adquiridos, e ressalvada, em todos os casos, a apreciação judicial". Anula-se o ato ilegal ou revoga-se o ato inconveniente ou inoportuno. Caracteriza-se, especificamente, pela autorrevisão de seus atos, por ela própria (de ofício), ou por provocação de particular.

Pelo princípio da especialidade, as entidades estatais não podem alterar ou abandonar os objetivos para os quais foram constituídas, devendo sempre atuar vinculadas aos seus fins ou objeto social.

Cabe à lei definir a criação e a área de atuação de qualquer entidade da administração indireta (autarquias, empresas públicas, fundações, sociedades de economia mista etc.), não se admitindo o exercício de atividade diversa daquela legalmente admitida e estatutariamente fixada.

O princípio da presunção de legitimidade consiste na ideia de que a Administração Pública encontra-se revestida de autêntica permissão para militar ou agir, empreendendo todos os esforços na consecução e defesa do interesse social. Por conta deste princípio, todos os atos praticados pelos agentes públicos têm validade jurídica, assim como todas as ações implementadas no exercício funcional, sendo plenamente válidas.

O princípio da proporcionalidade reflete a busca do equilíbrio entre os meios e os fins utilizados no exercício das atividades, visando inibir práticas abusivas e desconexas. Quando a Administração utiliza medidas com intensidade ou extensão além do que caberia, ressalta a ilegalidade de sua conduta. O princípio da proporcionalidade é, assim, uma faceta do princípio da razoabilidade.

O princípio da segurança jurídica é a própria essência da ciência do Direito, de tal sorte que faz parte do sistema constitucional como um todo. Seu alcance muito amplo enquadra-se entre os princípios gerais de Direito, fundamentos normativos de todo sistema jurídico-positivo. 
O conceito de segurança jurídica coincide com uma das mais profundas aspirações do Homem; a da segurança em si mesma, e da certeza possível em relação ao que o cerca. É traduzível na necessidade de vislumbrar algo como estável, permitindo projetar alguma previsibilidade nos comportamentos cujos frutos são esperáveis, e não aleatoriamente, ao sabor do acaso.

Podemos tomar, por exemplo, a hipótese em que o ato administrativo contenha apenas irregularidade formal, e a invalidação acarrete maiores prejuízos do que o aproveitamento de seus efeitos jurídicos. Diante dessa circunstância, o administrador poderá proceder à convalidação daquele ato.

\subsubsection{Violação dos princípios}

Cabe destacar a importância da observância dos princípios nos dias de hoje, pois a atuação contrária aos seus preceitos acarreta a invalidade dos efeitos almejados pela Administração ou pelos seus prepostos.

Há que se enfatizar, ainda, que princípios são o esteio de todo ordenamento jurídico, dotado de normatividade; o norte interpretativo e o fundamento de validade da norma, representando a estrutura na qual se sustenta toda a pirâmide de leis e normas regulamentadoras do exercício funcional da Administração e cuja violação representa a negação do próprio Direito.

Muito embora os princípios constitucionais gozem de força normativa e aplicabilidade imediata, o Supremo Tribuna Federal tem entendido que, em regra, a alegação de violação a princípio não enseja a admissibilidade do Recurso Extraordinário; a um só tempo, está se negando sua força normativa, quanto à aplicação da técnica da interpretação, conforme se verifica pelo julgado a seguir:

EMENTA: CONSTITUCIONAL. AGRAVO REGIMENTAL EM AGRAVO DE INSTRUMENTO. CADERNETA DE POUPANÇA. CISÃO. CORREÇÃO MONETÁRIA. ALEGADA OFENSA AO ART. 5', II, XXXVI, LIV E LV, DA CF. AUSÊNCIA DE PREQUESTIONAMENTO. SÚMULAS 282 e 356 DO STF. INCIDÊNCIA. AGRAVO IMPROVIDO [...] II - O Tribunal entende não ser cabível a interposição de RE por contrariedade ao art. $5^{\circ}$,II, da Constituição Federal, quando a verificação da ofensa envolva a reapreciação de interpretação dada a normas infraconstitucionais pelo Tribunal a quo (Súmula 636 do STF). III - A orientação desta Corte, por meio de remansosa jurisprudência, é a de que a 
alegada violação ao art. $5^{\circ}$, LIV e LV, da Constituição, pode configurar, em regra, situação de ofensa reflexa ao texto constitucional, por demandar a análise de legislação processual ordinária, o que inviabiliza o conhecimento do recurso extraordinário. [...]. V - Agravo regimental improvido. Processo AI 749925 AgR / SP , STF, relator Min. Ricardo Lewandowski, 1 ${ }^{a}$ Turma, julgamento: 15.09 .2009 .

E M E N T A: RECURSO EXTRAORDINÁRIO - ALEGADA VIOLAÇÃO A PRECEITOS INSCRITOS NA CONSTITUIÇÃO DA REPÚBLICA AUSÊNCIA DE OFENSA DIRETA À CONSTITUIÇÃO CONTENCIOSO DE MERA LEGALIDADE - RECURSO EXTRAORDINÁRIO NÃO CONHECIDO. - As alegações de desrespeito aos postulados da legalidade, do devido processo legal, da plenitude de defesa e da motivação dos atos decisórios, por dependerem de exame prévio e necessário da legislação comum, podem configurar, quando muito, situações caracterizadoras de ofensa meramente reflexa ao texto da Constituição, o que não basta, só por si, para viabilizar o acesso à via recursal extraordinária. Precedentes. - O procedimento hermenêutico do Tribunal de jurisdição inferior - quando examina o quadro normativo positivado pelo Estado e dele extrai, para resolução do litígio, a interpretação dos diversos diplomas de natureza infraconstitucional que o compõem - não transgride, diretamente, o princípio da legalidade. Precedentes. Processo RE 197825 / SP, relator Min. Marco Aurélio, 2ª turma, julgamento 14.03.2006.

Há vetusto entendimento no âmbito do Supremo Tribunal Federal de que só cabe Recurso Extraordinário por violação direta à Constituição. Compreende-se por violação não reflexa aquela que, para análise da questão constitucional, não dependa da interpretação pelo STF de matéria infraconstitucional. Ao se concluir que, em regra, a alegação de violação à princípio não enseja a admissibilidade do Recurso Extraordinário, a um só tempo, está se negando sua força normativa, quanto à aplicação da técnica da interpretação conforme ${ }^{32}$.

O Supremo Tribunal Federal, como guardião da Constituição Federal, é o órgão competente para apreciar e dar a última palavra acerca do conteúdo constitucional. Portanto, ainda que haja a alegada violação reflexa, a corte superior deve apreciar os fundamentos do recurso para que analise se foi dada interpretação conforme a Constituição, impedindo que seus dispositivos sejam vilipendiados.

\footnotetext{
${ }^{32}$ LIMA, Isan Almeida. Do cabimento de recurso extraordinário por violação a princípio. Aplicação do neoconstitucionalismo e neoprocessualismo na teoria dos recursos. In: Jus Navigandi, Teresina, ano 15, n. 2507, 13 maio 2010. Disponível em: 〈http://jus.com.br/revista/texto/14843〉. Acesso em: 9 jan. 2013.
} 


\subsection{PRINCÍPIO DA PRECAUÇÃO: UM PRINCÍPIO JURÍDICO}

A noção de precaução não é um conceito jurídico, mas uma ideia comum, ao alcance de todos. Segundo Cretella Neto ${ }^{33}$, "A precaução tem como substrato emocional, basicamente, o medo do desconhecido".

Precaução vem do latim praecautio-onis, derivando de praecavere, que significa ser cauteloso ou guardar-se; também pode significar prudência genérica com respeito a um perigo de dano ou risco. Pode, ainda, em aplicação mais concreta, indicar atos acautelatórios $^{34}$.

O princípio da precaução está fundamentado na percepção de que qualquer dúvida deva ser considerada como elemento autorizativo para a implementação de providência a fim de afastar um perigo. Segundo esse princípio, a mais remota possibilidade da existência de algum risco potencial à saúde ou ao meio ambiente, mesmo que não comprovada de forma científica, justifica a adoção de medidas que busquem evitar o evento danoso.

O princípio da precaução já está consagrado em matéria relacionada ao Direito Ambiental, na qual é fundamental a interferência do Estado, bem como em matéria ligada ao Direito do Consumidor, em que encontra indiscriminada aplicação, a partir da ideia de que os alimentos geneticamente modificados (transgênicos) representariam risco à saúde dos consumidores.

Zlata Drnas de Clément ${ }^{35}$, esclarece que:

El principio de precaución tiene su origen em um antiguo canon del comportamento humano, correspondiéndose a uma visión renovada de la ancestral concepción de "prudencia" ante lo incerto, lo desconocido. Em la "prudencia" se enlazan la "conjetura" basada em la "memoria", la "inteligencia" com su razonamiento indicativo-deductivo (analogia com lo conocido) y la "providencia" (disposición antecipada para evitar o minimizar los daños o males supuestos y temidos). Implica uma actitude de reserva, circunspección, prevision. ${ }^{36}$

\footnotetext{
${ }^{33}$ CRETELLA NETO, José. Direito Processual na Organização do Comércio - OMC. Rio de Janeiro: Forense, 2003. p. 224.

${ }^{34}$ LOPEZ, Teresa Ancona. Princípio da Precaução e Evolução da Responsabilidade Civil. São Paulo: Quatier Latin, 2010. p.99.

${ }^{35}$ CLÉMENT, Zlata Drnas de. El Principio de Precaución Ambiental - La Prática Argentina. Córdoba: Lerner Editora SRL, 2008. p. 14.

${ }^{36} \mathrm{O}$ princípio da precaução tem suas origens em um antigo canon do comportamento humano, correspondendo a uma visão renovada do antigo conceito de "prudência" diante do que é incerto, o desconhecido. Na "prudência"
} 
José Cretella $\mathrm{Neto}^{37}$, em rica e minuciosa pesquisa acerca do referido princípio, ensina que:

O princípio da precaução (precautionary principle) baseia-se na ideia de que qualquer incerteza deve ser interpretada com vistas à adoção de determinada medida de salvaguarda. Segundo esse princípio, a mera cogitação da existência de algum risco potencial à saúde ou ao meio-ambiente, ainda que não comprovado de forma cientifica, justifica a adoção de medidas que evitem o dano temido.

Juarez de Freitas ${ }^{38}$, por sua vez, assevera que o princípio da precaução, dotado de eficácia direta e imediata, impõe ao Poder Público diligências não tergiversáveis, com a adoção de medidas antecipatórias e proporcionais, mesmo no caso de incerteza quanto à produção de danos fundadamente temidos (juízo de verossimilhança).

Entretanto, a Bioética e o Biodireito também se valem do referido preceito a fím de utilizá-lo como mecanismo de proteção às pesquisas ligadas à biotecnologia.

No Brasil, o Princípio 15 da Declaração do Rio sobre Meio Ambiente e Desenvolvimento, estatui que :

Com o fim de proteger o meio ambiente, o princípio da precaução deverá ser amplamente observado pelos Estados, de acordo com suas capacidades. Quando houver ameaça de danos graves ou irreversíveis, a ausência de certeza científica absoluta não será utilizada como razão para o adiamento de medidas economicamente viáveis para prevenir a degradação ambiental.

O princípio da precaução é destacado pelo importante papel que desempenha no cenário moderno, isto é, no contexto de grandes avanços tecnológicos, notadamente no que se refere às atividades biotecnológicas, o que vem nutrindo na sociedade tanto o sentimento de esperança de um futuro promissor quanto as incertezas de eventuais riscos à saúde dos indivíduos e ao meio ambiente. $\mathrm{O}$ interesse pelo tema justifica-se por envolver aspectos ligados à vida humana e à proteção ao meio ambiente, dando impulso aos princípios bioéticos e biocientíficos. A relevância desses fatos leva à inevitável influência no âmbito jurídico, destacando-se a criação de novos institutos.

se enlaçam a "conjectura" baseada na "memória" e "inteligência" com seu raciocínio indutivo-dedutivo (analogia com o conhecido) e a "providência" (disposição antecipada para evitar ou minimizar os danos ou supostos males temidos). Implica em uma atitude de reserva, circunspecção, previsão (tradução livre).

${ }^{37}$ CRETELLA NETO, José. Direito Processual na Organização do Comércio - OMC. Rio de Janeiro: Forense, 2003. p. 224.

${ }^{38}$ FREITAS, Juarez. Sustentabilidade - Direito ao Futuro. 2. ed.Belo Horizonte: Fórum, 2012. p. 285. 
Observe-se, dessa forma, a relevância do Princípio da precaução para melhor tratamento dos problemas envolvendo biossegurança, seja sob o prisma do bioético, seja sob o prisma do biojurídico.

Este princípio permite que sejam tomadas medidas em relação a certos fenômenos, como é o caso das alterações climáticas, sem que seja necessário esperar pelas provas completas e irrefutáveis da existência de perigo iminente.

A não adoção do princípio da precaução configura, ou pelo menos tem o condão de configurar, omissão antijurídica, específica, certa e anômala. Desse forma, do mesmo modo como ocorre, na hipótese de ausência de prevenção exigível, a falta ou a falha, na precaução pode gerar dano injusto e, por conseguinte, indenizável.

\subsection{PRINCÍPIO DA PREVENÇÃO}

Zlata Drnas de Clément ${ }^{39}$ adverte que o princípio da precaução diferencia-se da prevenção, na medida em que aquele se aplica em situações de risco incerto.

José Cretella Neto ${ }^{40}$ informa que "Precaução é conceito que, de certo modo, atua em sentido contrário ao da lógica jurídica clássica, baseada no princípio da prevenção, o qual ampara legalmente a imposição de medidas destinadas a evitar danos que costumam efetivamente ocorrer".

Sérgio Cavalieri Filho, por sua vez, destaca que o Princípio da Prevenção vem ganhando relevo, exemplificando tal afirmação com o dispositivo contido no artigo $6^{\circ}$, inciso VI, do CDC, lembrando que “[...] embora a função ressarcitória da responsabilidade civil seja preponderante, busca-se modernamente evitar a ocorrência de novos danos para que não tornem socialmente insuportáveis".

O Código de Defesa do Consumidor, no Capítulo IV, Seção I, apresenta típica conotação preventiva, mormente ao proibir a colocação, no mercado de consumo, de produtos ou serviços que apresentem alto grau de nocividade ou periculosidade.

\footnotetext{
${ }^{39}$ CLÉMENT, Zlata Drnas de. El Principio de Precaución Ambiental - La Prática Argentina. Córdoba: Lerner Editora SRL, 2008. p. 14.

${ }^{40}$ CRETELLA NETO, José. Direito Internacional do Meio Ambiente. São Paulo: Saraiva, 2012. p. 223.
} 
De acordo com Juarez de Oliveira ${ }^{41}$, são os elementos centrais identificados no princípio da prevenção: “(a) alta e intensa probalidade (certeza) de dano especial e anômalo; b) atribuição e possibilidade de o Poder Público evitar o dano social, econômico ou ambiental; c) ônus estatal de produzir a prova da excludente do nexo de causalidade intertemporal".

\subsection{PRINCÍPIO DA PRECAUÇÃO X PREVENÇÃO DE RISCOS}

Já está pacificado o entendimento de que Prevenção e Precaução são proposições distintas. Prevenir é acautelar-se daquilo que, conhecidamente, se entende como causador do dano; de outra banda, precaver advém de algo de que não se tem certeza científica sobre a potencialidade lesiva da conduta, do produto ou da substância etc.

Não se pode tratar coisas distintas atribuindo-lhes o mesmo vocábulo, sobretudo no âmbito jurídico, visto que a clareza conceitual proporciona o controle mais eficiente das ações estatais. Portanto a correta definição não se configura apenas de filigrana, já que haverá repercussões práticas.

Conforme ensina Teresa Ancona Lopez ${ }^{42}$, às vezes há confusão entre os conceitos de precaução e prevenção, em decorrência do fato de, em ambos os casos, existir a possibilidade de acontecimento danoso. Porém não são da mesma natureza: no caso da precaução, trata-se da probabilidade de que a hipótese esteja certa. Por outro giro, na hipótese de prevenção, o perigo é estabelecido e cuida-se de probabilidade de acidente.

No princípio da prevenção, implícito no artigo 225 da CF de 1988, sua relevância está adstrita à necessidade de implementar medidas que impeçam a ocorrência de danos. $\mathrm{O}$ artigo 225, caput, da Constituição de 1988, em seu artigo 225, adotou expressamente o princípio da prevenção, conforme se observa:

Art. 225 - Todos têm direito ao meio ambiente ecologicamente equilibrado, bem de uso comum do povo e essencial à sadia qualidade de vida, impondose ao Poder Público e à coletividade o dever de defendê-lo e preservá-lo para as presentes e futuras gerações.

\footnotetext{
${ }^{41}$ FREITAS, Juarez. Sustentabilidade - Direito ao Futuro. 2.ed. Belo Horizonte: Fórum, 2012. p. 285.

${ }^{42}$ LOPEZ, Teresa Ancona. Princípio da Precaução e Evolução da Responsabilidade Civil. São Paulo: Quatier Latin, 2010. p. 101.
} 
Nos dizeres de José Cretella Neto ${ }^{43}$,

Precaução é conceito que, de certo modo, atua em sentido contrário ao da lógica jurídica clássica, baseada no princípio da prevenção, o qual ampara legalmente a imposição de medidas destinadas a evitar danos que costumam efetivamente ocorrer, na prática (ex.: determinados tipos de moléstias, cuja causa pode ser estatisticamente correlacionada à exposição a produtos químicos) ou cuja ocorrência é bastante provável, se presentes certos fatores de risco, de forma isolada ou combinada.

\subsection{A EFETIVIDADE DO PRINCÍPIO DA PRECAUÇÃO}

Se a aplicação de tal princípio acaba parecendo onerosa, vale lembrar a lição do Ministro Pedro Lessa, referindo-se à doutrina objetiva, para quem o aparelho administrativo não está devidamente organizado e o único remédio contra tal desorganização "seria, precisamente, forçar o Estado, por aplicação severa da regra da responsabilidade, a escolher empregados mais esclarecidos e mais devotados aos interesses públicos" ${ }^{\text {} 44}$.

Irene Patrícia Nohara ${ }^{45}$ ressalta o alcance do princípio da eficiência, vinculando sua efetividade à observância ao princípio da precaução, nos seguintes termos:

Com análise das guerras mundiais, dos problemas ambientais com efeitos supranacionais provocados pela ação humana e das transformações nas relações sociais, com a flexibilização da jornada e do local de trabalho e as modificações nas relações de família, a coletividade deparou-se com a transnacionalização dos chamados "riscos civilizacionais".[...]

[...] O princípio da precaução e a necessidade do justo equacionamento do risco também do ponto de vista internacional passaram a ser a tônica da discussão contemporânea. Nesta perspectiva, ressaltou-se o valor da eficiência e rapidez, uma vez que, para evitar a situação de catástrofe em âmbito internacional e também nacional, é necessário que haja maior flexibilidade das estruturas organizacionais, que incluem os Estados nacionais.

\footnotetext{
${ }^{43}$ CRETELLA NETO, José. Direito Processual na Organização do Comércio - OMC. Rio de Janeiro: Forense, 2003. p. 225.

44 WALD, Arnoldo. Os Fundamentos da Responsabilidade Civil do Estado. In: Revista de Informação Legislativa, Brasília, ano 30, nº 117, jan/mar 1993. p. 22.

${ }^{45}$ NOHARA, Irene Patrícia. Reforma Administrativa e Burocracia. São Paulo: Atlas, 2012. p. 154 (grifo nosso).
} 
Para a referida autora, o princípio da eficiência positivado pela Emenda Constitucional 19/98 encontra eco na observância do princípio da precaução, uma vez que este princípio alberga tamanha importância que sua aplicação não se restringe ao direito pátrio, irradiando também no campo internacional.

A globalização e a integração entre as nações, assim como o empreendimento na Sociedade moderna, intensificaram o potencial de transnacionalidade dos riscos ao meio ambiente, à saúde pública, e por via de consequência, à proteção à vida. Na prática, o âmbito de aplicação do princípio é muito mais amplo e estende-se igualmente à política dos consumidores e à saúde humana, animal ou vegetal.

De acordo com o princípio da precaução, se houver evidências científicas razoáveis de qualquer natureza para se acreditar que uma atividade, tecnologia ou substância possam ser nocivas, obriga-se o agente a agir no sentido de evitar o mal. Esperar sempre pela certeza científica pode ocasionar sofrimento e morte, e os danos ao universo natural podem ser irreversíveis, perpetuando-se por um longo período. Este princípio é aplicado, portanto, sempre que subsista uma incerteza ou enquanto não se dispuser de informações científicas completas sobre o risco potencial.

A aplicação do princípio da precaução encontra grande resistência, e uma delas é a exigência de certeza científica como uma norma, segundo a qual se supõe que se a previsão do dano não puder ser comprovada cientificamente, não pode ser considerada como verdadeira. A ausência de certeza é utilizada, assim, para justificar a continuidade do uso de uma tecnologia ou substância nociva.

Outra circunstância em que ocorre essa resistência é a utilização da "avaliação de riscos", cuja margem é muito estreita, com o objetivo de determinar se uma prática específica deve ser regulamentada. Ainda, outra hipótese igualmente resistente é a "análise do custo/ benefício".

Muito embora o princípio da precaução represente um grande avanço no sentido de preservar a saúde pública, o meio ambiente, a vida, enfim a integridade humana em sua plenitude, é necessário certa cautela para que a aplicação desse princípio não se torne, nas mãos de insensatos, um instrumento para a prática de ações arbitrárias, nem tampouco legitime um Estado intervencionista. 


\subsection{APLICAÇÃO DA PRECAUÇÃO E PREVENÇÃO NA ATIVIDADE ESTATAL}

A possibilidade de aplicação do princípio da precaução à atividade estatal é perfeitamente viável, na medida em que o Estado deve utilizar-se de todos os recursos disponíveis como base para justificar a implementação de medidas de salvaguarda frente a uma hipotética ocorrência de dano irreparável.

Nesse sentido, recorremos às lições de Aristóteles, que afirmava que "tem-se como característica do homem prudente ser ele capaz de deliberar sobre o que é bom e proveitoso para si mesmo, não num ramo particular, mas o que é vantajoso ou útil como recurso para o bem-estar geral ${ }^{46,}$.

O filósofo segue, complementando que:

Por isso homens como Péricles são julgados prudentes porque possuem uma faculdade de discernir que coisas são boas para si mesmo e para os seres humanos. E é por isso que coincide com nosso entendimento do que seja alguém conhecedor da administração doméstica e administração política.

Entretanto, deve-se tomar cuidado com situações em que, sob o discurso da proteção integral, o Estado promova a retaliação comercial. Exemplo claro ocorreu no episódio em que o governo canadense proibiu a entrada de carne brasileira, rotulada como suspeita, apenas como forma de tentar atingir o mercado aeronáutico.

Em 02 de fevereiro de 2.001, uma sexta-feira, o Canadá decretou o bloqueio das importações de carne brasileira, no que foi seguido pelos Estados Unidos e pelo México, gerando uma onda de protestos e declarações belicosas diante das câmeras, graças à rápida propagação da versão oficial do governo brasileiro, que se colocou como vítima de uma retaliação comercial decorrente da disputa entre as fabricantes de aviões, a nacional Embraer e a canadense Bombardier. ${ }^{47}$ Os periódicos Veja, Isto é e Época publicaram manchetes como por exemplo: "Não é a vaca que está louca: incomodado com o crescimento da Embraer, o Canadá parte para a retaliação e inventa que a carne brasileira está contaminada."

Naquele episódio, havia um alerta para as autoridades brasileiras: o ponto mais importante a ser observado não era se, no Brasil, havia ou não foco da doença conhecida

\footnotetext{
${ }^{46}$ ARISTOTELES. Ética à Nicômaco. Tradutor Edson Bini. 2.ed. São Paulo: Edipro, 2007. p. 182.

${ }^{47}$ FELICIO, Pedro Eduardo. Brasil X Canadá: Histórico De Uma Crise Que Poderia Ter Sido Evitada. Disponível em: <http://www.fea.unicamp.br/deptos/dta/carnes/files/Brasil_x_Canada.pdf >. Acesso em: 22 dez. 2012.
} 
como "vaca louca", mas certificar-se de que o país estava tomando as medidas preventivas para evitar a contaminação.

Nessa esteira de raciocínio, vale recorrer às lições de Juarez de Freitas ${ }^{48}$, segundo o qual existe proibição constitucional para o excesso de inércia (ou omissão desproporcional), entretanto, esse novo panorama que se apresenta requer um também novo foco hermenêutico, especificamente para concretizar os emergentes princípios da precaução e da prevenção.

Gascón y Marín ${ }^{49}$ aponta alguns dispositivos legais que contêm, de forma implícita, a observância do princípio da prevenção como forma de evitar a ocorrência de danos:

[...] O art. 56 da Lei das Águas autoriza, para prevenir inundações ou conter as iminentes, a praticar, em caso de urgência, obras provisórias ou destruir as existentes em todo tipo de prédios, admitido o princípio da indenização por perdas e danos. As disposições sanitárias autorizam a destruição de objetos quando o exija a garantia da desinfecção, devendo o dono ser indenizado pelo Ayuntamento (art. 132). O regulamento de epidemias de 04.06.1915, Lei 18.09.1914, firma o princípio de indenizar particulares, quando se lhes imponham medidas que causem prejuízos econômicos.

\section{Conclusão}

As reflexões expostas neste capítulo têm a finalidade de reconsiderar as bases do direito administrativo, pois só é concebível um direito que privilegie a visão antropocêntrica, mesmo porque o ser humano é a razão de o Estado existir. O Estado assumiu o importante papel de concretizar os direitos fundamentais, entretanto tem obrigação de lançar mão de todos os recursos a fim de garantir sua efetivação.

Não se trata de um Estado intervencionista, mas um Estado cuidador, atento e diligente; nesse espírito, a recepção dos princípios da precaução e da prevenção no estudo do direito administrativo, mais especificamente na análise da Responsabilidade Estatal, se apresentam como uma nova perspectiva, um novo rumo no sentido de aperfeiçoar a atuação do Estado no exercício de suas atividades.

\footnotetext{
${ }^{48}$ FREITAS, Juarez. Sustentabilidade - Direito ao Futuro. 2. ed. Belo Horizonte: Fórum, 2012. p. 281.

${ }^{49}$ GASCÓN Y MARÍN, José. Tratado de Derecho Administrativo. vol. 1. 11. ed. Madrid: Ed. C. Bermejo, 1950. p. 554558 apud CRETELLA JR., José. O Estado e a Obrigação de Indenizar. 2. ed. Rio de Janeiro: Forense, 2002. p. 164.
} 
A contribuição de Ronald Dworkin e Robert Alexy proporcionou a reaproximação da ética com o Direito. Superando as doutrinas positivistas, estes doutrinadores defenderam a inclusão de um novo tipo de norma no ordenamento jurídico, as chamadas normas princípio, que, juntamente com as normas regras, regulariam as condutas.

É certo que aos operadores do direito caberá a tarefa de delinear novos limites, valores e princípios, visando implementar, na Ciência Jurídica, a interdisciplinaridade inerente a essa nova realidade tecnológica e cultural que vem transformando todo o cenário mundial.

O princípio da precaução pode ser invocado sempre que seja necessária uma intervenção urgente face a um possível risco para a saúde humana, animal ou vegetal, ou quando necessário para a proteção do ambiente, caso os dados científicos não permitam uma análise completa do risco, ou seja, não permitam medir o risco com certeza suficiente.

Tal princípio somente poderá ser invocado na hipótese de risco potencial, não podendo nunca justificar a tomada de decisão arbitrária, e sua aplicação fica condicionada à verificação de três condições: a) identificação dos efeitos potencialmente negativos; b) avaliação dos dados científicos disponíveis; c) extensão das incertezas científicas.

O princípio da precaução se mostra como uma alternativa inovadora para preservar a humanidade de ameaças reais ou mesmo do sentimento generalizado de medo em relação à defesa da saúde pública, da qualidade dos alimentos e do equilíbrio do meio ambiente.

No mundo em que vivemos, fatos e atos modificam a natureza das coisas e a vida das pessoas, para melhor ou para pior, conforme disposição das normas e regras ou com a infração de tais normas ou regras. Em certa medida, os acontecimentos têm vontade própria, ocorrem independentemente do querer humano e proporcionam mutações grandes ou pequenas nas coisas e nos indivíduos. Nesses casos, via de regra, nenhum indivíduo é responsável pelo evento, nenhuma pessoa natural ou jurídica ou entidade criada pelo homem é chamada a responder pelas mudanças operadas, como lhes tendo dado causa.

No entanto, mesmo no terreno dos fatos, pode incidir a responsabilização, como, por exemplo, no caso em que a previsibilidade humana poderia ter ceifado os efeitos danosos do fato do mundo. Neste caso, excepcionalmente, o indivíduo adere ao fato para efeitos de responsabilidade, porque embora não seja causa direta do fato é causa direta do dano, pois podendo impedi-lo não o fez ${ }^{50}$.

\footnotetext{
${ }^{50}$ CRETELLA JR., José. O Estado e a obrigação de indenizar. Rio de Janeiro: Forense, 2002. p. 25.
} 
E fechamos o nosso raciocínio abraçando as considerações de Juarez de Freitas ${ }^{51}$, mas indo mais longe. Para ele, o princípio da prevenção, em Direito Administrativo e no Direito Ambiental, determina, sem mora ou sofisma acomodatício, o cumprimento, diligente, eficiente e eficaz, da obrigação estatal de impedir o nexo causal de danos perfeitamente previsíveis.

Por fim, concluímos que, aliado ao princípio da prevenção, o da precaução também encontra destaque, uma vez que não há pretexto para a passividade complacente, submissa e servil do Ente Estatal.

${ }^{51}$ FREITAS, Juarez. Sustentabilidade - Direito ao Futuro. 2.ed. Belo Horizonte: Fórum, 2012. p. 284. 


\section{O CONTROLE COMO MECANISMO PARA EVITAR O DANO}

\subsection{O CONCEITO DE “CONTROLE”}

A Declaração dos Diretos do Homem e do Cidadão, aprovada em 26 de agosto de 1.789, contendo 17 artigos, inspirada nos pensamentos iluministas e na Revolução americana, preceitua, em seu artigo 15, que "A sociedade tem o direito de pedir conta a todo agente público de sua administração". É sabido que aquele que atua em nome de outro deve prestar contas de sua atuação.

Controle $^{1}$ da Administração Pública pode ser traduzido como o conjunto de elementos que concorrem para operar a vigilância, o direcionamento e a correção da atividade administrativa, para que ela não se afaste das normas e princípios contidos no ordenamento jurídico, tampouco dos interesses públicos pelos quais está obrigada a zelar. São elementos básicos do controle, a fiscalização e a revisão.

A fiscalização é a verificação que se faz acerca da atividade administrativa desenvolvida pelos órgãos e pelos agentes públicos. Já a revisão é o poder de corrigir as condutas administrativas.

Edmir Netto de Araújo $^{2}$ prefere a expressão Controle da Administração, para denominar o sentido de fiscalização e monitoramento da atividade estatal, pois, para ele, a expressão controle administrativo é restritiva, envolvendo predominantemente o controle interno da administração sobre si mesma. Assim, o conceito de Controle da Administração pode ser apontado como:

[...]o conjunto de mecanismos e atividades, jurídicos, jurisdicionais e administrativos, para o exercício da fiscalização e revisão que sobre ela exercem órgãos dos Poderes Judiciário, Legislativo e do próprio Executivo, às vezes como faculdade de vigilância, orientação e correção, outras como

\footnotetext{
${ }^{1}$ A palavra controle é de origem francesa (contrôle) e, por isso, sempre encontrou resistências entre os cultores do vernáculo. Mas, por ser intraduzível e insubstituível no seu significado vulgar ou técnico, incorporou-se definitivamente em nosso idioma, já constando dos modernos dicionários da Língua Portuguesa nas suas várias acepções. E, no direito pátrio, o vocábulo controle foi introduzido e consagrado por Seabra Fagundes desde a publicação de sua insuperável monografia O Controle dos Atos Administrativos pelo Poder Judiciário $\left(1^{\mathrm{a}}\right.$ edição, 1941). In: MEIRELLES, Hely Lopes. Direito Administrativo Brasileiro. 37. ed. São Paulo: Malheiros, 2011. p. 713 (NOTA DE RODAPÉ).

${ }^{2}$ ARAUJO, Edmir Netto de. Curso de Direito Administrativo. 5. ed. São Paulo: Saraiva, 2010. p. 1181.
} 
poder-dever indisponível, objetivando a conformação da atuação do agente, órgão ou entidade à legalidade, conveniência e oportunidade, supremacia do interesse público e outros princípios que decorrem do ordenamento jurídico.

Celso Antonio Bandeira de Mello ${ }^{3}$, tratando do tema, faz importante menção à lei $\mathrm{n}^{\text {o }}$ 4.898, de 9 de dezembro de 1965, que regula o direito de representação e o processo de responsabilidade administrativa, civil e penal, nos casos de abuso de autoridade. De acordo com o referido dispositivo legal, qualquer pessoa pode suscitar o controle da administração para que seja sancionado o agente que haja incidido em abuso de autoridade. Para efeitos desta norma legal, classifica-se como autoridade o agente que exerce cargo, função ou emprego público, de natureza civil ou militar, mesmo que de caráter transitório e sem remuneração, nos termos do art. $5^{\circ}$ da referida lei.

Nas palavras de Hely Lopes Meirelles ${ }^{4}$, "Controle, no âmbito da administração pública, é a faculdade de vigilância, orientação e correção que um Poder, órgão ou autoridade exerce sobre a conduta funcional do outro. Tratando-se de administração direta ou centralizada decorre da subordinação hierárquica", e, na esfera da Administração indireta ou descentralizada, é produto da vinculação administrativa, nos termos da lei instituidora das entidades que a compõem.

De acordo com as lições de José Carvalho dos Santos Filho ${ }^{5}$, denomina-se controle da Administração Pública: “o conjunto de mecanismos jurídicos e administrativos por meio dos quais se exerce o poder de fiscalização e de revisão da atividade administrativa e qualquer das esferas de Poder".

A vigilância configura-se pela observância constante da atuação exercida pelos mandatários das atividades estatais, imprescindíveis para a marcha administrativa. Para demonstrar a importância da vigilância, recorremos ao mito de Gyges, descrito na obra de Platão intitulada República. O personagem dessa história, um pastor chamado Gyges, encontra por acaso uma caverna onde jaz um cadáver que usava um anel. Quando Gyges coloca o anel no próprio dedo, descobre que, ao retorcê-lo, se torna invisível. Sem ninguém para monitorar seu comportamento, Gyges passa a praticar más ações - seduz a rainha, mata o rei e se apossa do poder e segue praticando inquidades. Essa história levanta uma questão

\footnotetext{
${ }^{3}$ BANDEIRA DE MELlO, Celso Antonio. Curso de Direito Administrativo. 28. ed. São Paulo: Malheiros. 2011. p. 945-946.

${ }^{4}$ MEIRELLES, Hely Lopes. Direito Administrativo Brasileiro. 37. ed. São Paulo: Malheiros, 2011. p. 713.

${ }^{5}$ CARVAlHO FILHO, José dos Santos. Manual de Direito Administrativo. 25. ed. São Paulo: Atlas. 2012. p. 929.
} 
moral: o homem não seria capaz de resistir à prática do ilícito se soubesse que seus atos não seriam testemunhados ou punidos.

A vigilância é necessária, pois conforme já advertia Montesquieu, "todo aquele que tem o poder tende a abusar dele [...]. O poder vai até onde encontra limites. Só o poder controla o poder". Essa máxima se põe mais atual que nunca.

De outra banda, está o direcionamento ou a orientação da conduta estatal que tem por objetivo guiar a atuação administrativa rumo ao atendimento das necessidades coletivas.

A Advocacia Geral da União, assim como a Procuradoria Federal, do Estado e do Município cumprem a tarefa de direcionamento ou orientação por meio da emissão de pareceres, mediante solicitação dos órgãos aos quais estão vinculados.

No que diz respeito à correção, esta visa ao realinhamento das condutas desviadas das normas jurídicas, dos princípios e até mesmo do interesse público, quando se verifica a ocorrência de hipótese na qual o agente público se distancia dos ditames os quais a conduta estatal deve trilhar, e o Estado tem possibilidade de detectar tal anormalidade, lançando mão dos mecanismos de controle colocados à sua disposição, e restabelecendo a ordem natural das coisas.

O Estado é soberano, o poder exercido é uno e indivisível. No entanto, o exercício desse poder poderá ser feito por diversos órgãos que o compõem.

Montesquieu $^{6}$ propagava que o exercício do Poder concentrado nas mãos de um só indivíduo conduz ao arbítrio e à tirania. Dessa forma, visando evitar tais malefícios, este filósofo exalta a necessidade de haver uma separação das funções do Estado:

[...] é uma experiência eterna a de que todo homem que tem poder tende a abusar dele; ele vai até onde encontra limites. Quem o diria! a própria virtude tem necessidade de limites. Para que não se possa abusar do poder é preciso que, pela disposição das coisas, o poder detenha o poder. [...] Quando na mesma pessoa ou no mesmo corpo de magistratura o poder legislativo está reunido ao poder executivo, não há liberdade, porque se pode temer que o mesmo monarca ou o mesmo senado façam leis tirânicas para executá-las tiranicamente. Não há liberdade se o poder de julgar não está separado do poder legislativo e do executivo. Se ele estivesse confundido com o poder legislativo, o poder sobre a vida e a liberdade dos cidadãos seria arbitrário, pois o juiz seria legislador. Se ele estiver confundido com o poder executivo, o juiz poderá ter a força de um opressor. Tudo estaria perdido se o mesmo homem ou o mesmo corpo de principais, nobres ou povo, exercessem estes três poderes: o de fazer as leis, o de executar as resoluções públicas e o de julgar as questões dos particulares.

\footnotetext{
${ }^{6}$ MONTESQUIEU, Charles de Secondat, Baron de. Do Espírito das Leis. Tradução Roberto Leal Ferreira. São Paulo: Martin Claret, 2010. p. 167-168.
} 
A Administração Pública, enquanto atividade estatal voltada para a realização do interesse público, por cuidar da gestão de interesses alheios, deve ser controlada por meio de instrumentos adequados para evitar a ocorrência de arbitrariedades, ilegalidades e lesões a direitos individuais.

Niklas Luhmann ${ }^{7}$ definia controle como sendo o exame crítico de processos decisórios, objetivando uma intervenção transformadora no caso de o processo decisório em seu desenvolvimento não corresponder às considerações do controle.

Em todas as suas manifestações, o Poder Público deve atuar com legitimidade, ou seja, segundo as normas pertinentes a cada ato e de acordo com a finalidade e o interesse coletivo na sua realização. Infringindo as normas legais, ou relegando os princípios básicos da Administração, ou ultrapassando a competência, ou, ainda, se desviando da finalidade institucional, o agente público vicia o ato com ilegalidade e o expõe à anulação pela própria Administração ou pelo Judiciário, em ação adequada.

A Administração, no papel de gestora de determinados interesses que a lei classifica como públicos e considerando que a defesa e o prosseguimento desses interesses são obrigatórios e também legítimo dever estatal, está encarregada da continuidade da atividade administrativa sendo princípio que se impõe, prevalecendo em quaisquer circunstâncias.

No exercício de suas funções, a Administração Pública se sujeita ao controle por parte dos Poderes Legislativo e Judiciário, além de exercê-lo, ela mesma, sobre seus próprios atos.

A finalidade do controle é assegurar que a Administração Pública execute suas atividades em consonância com os princípios acolhidos pelo ordenamento legal, como os da legalidade, moralidade, finalidade pública, publicidade, motivação, impessoalidade, e outros princípios, na atuação administrativa ${ }^{8}$.

Nesse sentido, Odete Medauar ${ }^{9}$, citando Jean Waline, nos traz a seguinte lição:

\footnotetext{
${ }^{7}$ LUHMANN, Niklas. Sociologia do Direito II. Tradução Gustavo Bayer. Rio de Janeiro: Tempo Brasileiro, 1985. p. 84-85 apud FRANÇA, Philip Gil. O Controle da Administração Pública. 2. ed. São Paulo: Revista dos Tribunais. p. 28.

${ }^{8}$ Nesse sentido ARAUJO, Edmir Netto de. Curso de Direito Administrativo. 5. ed. São Paulo: Saraiva, 2010. p. 1180, preferindo a terminologia CONTROLE DA ADMINISTRAÇÃO, pois considera o uso do termo controle administrativo restritivo ao controle interno da Administração sobre si mesma.

${ }^{9}$ MEDAUAR, Odete. Controle da Administração Pública. 2. ed. São Paulo: Revista dos Tribunais, 2012. p. 13 14 apud WALINE, Jean. Lévolution du contrôle de l'administration depuis um siécle. Revue du Droit Public et de la Science Politique, 1984. p. 1.327-1328.
} 
Todo controle é destinado num primeiro momento a assegurar a melhor execução do serviço e num segundo momento a analisar a atividade do serviço para aprimorá-lo; a Administração Pública tem a gestão dos serviços públicos e seu bom funcionamento é, então, primordial; por outro lado, a Administração funciona com recursos públicos e é também a melhor utilização do dinheiro público que está em causa; enfim, a obrigação de controle aparece mais imperiosa em razão das prerrogativas e poderes de que é dotada a Administração Pública; como, então, evitar que a Administração abuse dos poderes que lhe são conferidos? Há uma resposta clássica: pela sujeição da Administração ao Direito, isto é, pelo princípio da legalidade; mas é preciso ter certeza de que, se não houver observância desse princípio ou no caso de deficiência, tais falhas, propositais ou não, serão detectadas e os erros corrigidos.

O Controle da Administração pode ser interno ou externo, conforme seja realizado, ou não, pela própria Administração, respectivamente. Quando nos referimos ao controle interno este se concretiza pela aplicação do princípio da autotutela, do qual decorre o poder de mesmo nome.

Diógenes Gasparini ${ }^{10}$ adverte que, pelo Controle, a Administração Pública e os órgãos de administração do Legislativo e do Judiciário confirmam ou desfazem seus atos, confirmam quando estes são legítimos, convenientes oportunos e eficientes, ou anulam quando são ilegais, modificam ou revogam o legal, mas inconveniente, inoportuno ou ineficiente.

Nessa toada, se mostra de curial relevância esclarecer que o controle administrativo pode ser considerado ainda mais abrangente do que o controle da Administração Pública, considerando que os demais poderes - Legislativo e Judiciário também praticam atos administrativos para a gestão de seus quadros e, por isso, estão sujeitos ao controle administrativo, que difere do Controle da Administração propriamente dito ${ }^{11}$.

O escritor indiano George Orwell ${ }^{12}$, em sua obra de ficção “1984”, publicada em 1949, inspirado na opressão dos regimes totalitários das décadas 1930/1940, descreve em seu livro as circunstâncias e as consequências do controle excessivo perpetrado pelo Estado, proibindo as pessoas até mesmo de pensar ou agir livremente. Nessa obra, o autor faz referência ao controle exacerbado do Estado que vigia constantemente todos os indivíduos e pune severamente aqueles que apresentam comportamento considerado suspeito. Os próprios

\footnotetext{
${ }^{10}$ GASPARINI, Diógenes. Direito Administrativo. 10. ed. São Paulo: Saraiva, 2005. p. 819

${ }^{11}$ NOHARA. Irene Patricia. Direito Administrativo. São Paulo: Atlas, 2011. p. 800.

${ }^{12}$ ORWELL, George. 1984. Tradução Alexandre Hubner e Heloisa Jahn. São Paulo: Companhia das Letras, 2009.
} 
filhos ou vizinhos dos indivíduos eram incentivados a denunciar à "Polícia do Pensamento" quem cometesse um "crimideia”(crime de ideia). Esse quadro é assustador, na medida em que aniquila qualquer indício de democracia.

Segundo Jean Waline ${ }^{13}$ :

De manière um peu surprenante il n'y a pas, dans la doctrine contemporaine, de théorie générale du controle de l' Administration. Cela s'explique par le fait que pendant très longtemps on a confiné le problème du contrôle de l'Administration au seul contrôle par le juge. Mais il a bien fallu reconnaître que, quel que soit le três grand mérite de celui-ci, il ne pouvait subvenir à toutes les nécessités d'un contrôle efficace; on a donc vu apparaître, parallèlement au contrôle juridictionnel, um contrôle non juridictionnel de l'administration.

Na concepção de Roberto Dromi ${ }^{14}$, o Poder Público, na qualidade de Estado fiscalizador, mostra-se por meio de suas funções essenciais: governo e controle, o controle coexiste ao Estado, controlar não é reduzir direitos, mas compatibilizá-los e harmonizá-los para possibilitar a convivência social. O Estado fiscalizador implica um sistema de controle que abarca os controles político, legislativo, jurisdicional e administrativo, que garante a regular e eficiente marcha da administração e da sociedade.

El Estado debe ejercer el control, porque es presupuesto de la liberdad pública. La liberdad del hombre exige la responsabilidad em el ejercicio del poder de los derechos. No hay responsbilidad sin control.

O controle é indispensável, e sua relevância, mormente no combate à corrupção, é aspecto bastante suscitado nos dias atuais, não apenas pelos estudiosos do Direito Administrativo, mas também pelo cientistas políticos, filósofos contemporâneos entre outros.

\subsubsection{Classificação e tipologia}

No âmbito das ciências, inclusive no Direito, é comum os estudiosos elaborarem classificações dos diversos institutos, pois isso torna a respectiva compreensão mais eficaz, e mais facilmente alcançável, de forma mais didática e pedagógica.

\footnotetext{
${ }^{13}$ WALINE, Jean. Droit Administratif. 23. ed. Paris: DAlloz, 2010. p. 30.

${ }^{14}$ DROMI, Roberto. Derecho Administrativo. 5. ed. Buenos Aires: Ciudad Argentina, 1995. p. 45-49.
} 
Em acurado estudo sobre o Controle da Administração Pública, Odete Medauar ${ }^{15}$ cita alguns autores estrangeiros, apontando a variedade de tipologias e classificações das formas de controle, dificultando a unanimidade sobre o tema.

Gérard Bergeron ${ }^{16}$ oferece a seguinte classificação do controle em geral, utilizando diversos critérios e subcritérios: I - Quanto ao tempo (i-duração: permanentes e não permanentes; ii - momento: a priori e a posteriori); II - Quanto à direção (i-em altura: vindos do alto e vindos de baixo; ii-segundo a reversibilidade: reversíveis e irreversíveis); III Quanto à autoridade: unitaristas, federalistas e confederalistas; IV - Quanto à iniciativa (ativos, semiativos, passivos); V - Quanto à estrutura (i-de organização: institucionalizados, não institucionalizados; ii- de mediação: diretos e indiretos); VI - Quanto ao resultado (propulsivos e estabilizadores); VII - Quanto à pressão (sugestão e conselho, instrução e disciplina, comando e execução, ingerência e intervenção, anulação e reforma, gestão e apropriação, substituição e eliminação).

Jorge Silva Censio ${ }^{17}$, autor uruguaio, ressaltando que os controles são variados, apresenta a seguinte classificação: I - Quanto ao objeto: (i - controle sobre as pessoas, iicontrole sobre a atividade administrativa, iii-controle de legalidade, iv - controle de oportunidade ou conveniência, v - controle da legalidade e oportunidade); II - Quanto ao momento em que o controle se exerce (i-controle preventivo, ii-controle concomitantemente simultâneo, iii-controle a posteriori): III - Quanto à forma em que o controle "se põe em movimento" (i-controle de ofício, ii-controle a pedido da parte, iii-controle obrigatório; IV Quanto aos órgãos que atuam na função do controle $^{18}$ (i-controle intraorgânico, ii-controle interorgânico, iii-controle extraorgânico).

Guy Braibant, Nicole Questiaux e Celine Wiener ${ }^{19}$ apontam as seguintes modalidades de controle: I - Quanto aos órgãos (i-controle interno, ii- controle externo); II -

\footnotetext{
${ }^{15}$ MEDAUAR, Odete. Controle da Administração Pública. 2.ed. São Paulo: Revista dos Tribunais, 2012. p. $32-42$.

${ }^{16}$ BERGERON, Gérard. Functionnement de l'Etat. 2.ed. Paris: Armand Colin, 1965. p. 80 e ss. apud MEDAUAR, Odete. Controle da Administração Pública. 2. ed. São Paulo: Revista dos Tribunais, 2012. p. 33-34.

${ }^{17}$ CENSIO, Jorge Silva. El Control de la Administración. In: Revista de Direito Público 39/40, 1976. p. 5-19 apud MEDAUAR, Odete. Controle da Administração Pública. 2. ed. São Paulo: Revista dos Tribunais, 2012. p. 35.

${ }^{18} \mathrm{Na}$ classificação quanto aos órgãos que atuam na função de controle, Jorge Silva Censio aderiu à mesma tipologia adotada pelo argentino Roberto Dromi, inspirada em Karl Loewenstein. Dromi acrescenta a esta classificação o controle de entes estatais e o controle dos entes paraestatais.

${ }^{19}$ BRAIBANT, Guy; QUESTIAUX Nicole, WIENER Celine. Le Contrôle de l'Administration et la protection des cytoyens, Paris: Cujas, 1973. p. 220-221 apud MEDAUAR, Odete. Controle da Administração Pública. 2. ed. São Paulo:Revista dos Tribunais, 2012. p. 37.
} 
Quanto aos procedimentos (i-sobre os agentes, ii-sobre os atos da Administração; permanente, intermitente, por peças, in loco, de ofício, por iniciativa do órgão de controle, por reclamação); III - Quanto às funções (i - preventivo, ii - corretivo).

$\mathrm{Na}$ doutrina brasileira, Seabra Fagundes ${ }^{20}$ apresenta um tríplice sistema de controle das atividades estatais, com base naquele que o realiza: controle administrativo, controle legislativo e controle jurisdicional.

Edmir Netto de Araujo ${ }^{21}$ considera como mais importante o critério de classificação o qual divide o Controle nas modalidades de Interno e Externo, pois, para ele, este deve ter precedência sobre os demais, quer por abranger elementos de todos os outros ou, ainda, por focalizar estruturalmente os mecanismos de controle da Administração.

José dos Santos Carvalho Filho ${ }^{22}$ adota critérios de classificação segundo o enfoque que se queira dar, por exemplo: o controle segundo o órgão controlador pode ser, legislativo, executivo e judicial; quanto à extensão pode ser classificado em interno e externo; no que se refere à natureza temos o controle de legalidade e de mérito; quanto ao âmbito da Administração pode ser por subordinação ou por vinculação; quanto à oportunidade pode ser prévio, concomitante ou posterior; e finalmente quanto à iniciativa pode ser de oficio ou provocado.

O entendimento de Hely Lopes Meirelles ${ }^{23}$ é no sentido de que:

Os tipos e formas de controle da atividade administrativa variam segundo o Poder, órgão ou autoridade que o exercita ou o fundamento, o modo e o momento de sua efetivação.[...] Esse controles, conforme seu fundamento, serão hierárquicos ou finalísticos; consoante a localização do órgão que os realiza, podem ser internos ou externos; segundo o momento em que são feitos, consideram-se prévios, concomitantes ou subsequentes, ou, por outras palavras, preventivos, sucessivos ou corretivos, e, finalmente, quanto ao aspecto controlado, podem ser de legalidade ou de mérito.

Odete Medauar ${ }^{24}$ se baseia no critério do agente controlador, isto é, o órgão, ente, instituição ou pessoa que exerce a atividade de controle sobre a Administração Pública. O

\footnotetext{
${ }^{20}$ FAGUNDES . M. Seabra. O Controle dos Atos Administrativos pelo Poder Judiciário. 7. ed. Rio de Janeiro: Ed. Forense, 2005. p. 124-125.

${ }^{21}$ ARAUJO, Edmir Netto de. Curso de Direito Administrativo. 5. ed. São Paulo: Saraiva, 2010. p. 1182.

${ }^{22}$ CARVALHO FILHO, José dos Santos. Manual de Direito Administrativo. 25. ed. São Paulo:Atlas, p. 931-935.

${ }^{23}$ MEIRELLES, Hely Lopes. Direito Administrativo Brasileiro. 37. ed. São Paulo: Malheiros, 2011. p. 714.

${ }^{24}$ MEDAUAR, Odete. Controle da Administração Pública. 2. ed. São Paulo:Revista dos Tribunais, 2012. p. $42-43$.
} 
controle realizado por agente que integra o corpo da Administração Pública, classifica-se como controle interno; citamos, a título de exemplo, o controle hierárquico, a tutela administrativa, a fiscalização realizada por Inspetorias, Supervisões e Ouvidorias. Por outro lado, o controle realizado por órgão, agente ou Instituição estranhos à estrutura da Administração, classifica-se como controle externo; evidenciam-se tais situações nas hipóteses em que há atuação do Tribunal de Contas (órgão técnico-jurídico) ou Instituições políticas (partidos políticos).

\subsection{O CONTROLE INTERNO DA ADMINISTRAÇÃO}

O controle da Administração Pública é mecanismo, mais que fundamental, imprescindível para a garantia da ordem jurídica, cujo objetivo é impedir a conduta praticada fora dos limites do sistema institucionalizado, contrariando os valores que conformam o direito. São forças que determinam como a Administração deve se portar para cumprir sua missão constitucional ${ }^{25}$.

O Controle interno é aquele exercido pela própria Administração na relação de subordinação hierárquica, sobre seus próprios atos e agentes, ou por sistema de auditoria que acompanha seu exercício.

Em primeiro lugar, é necessário distinguir Controle Administrativo e Controle da Administração Pública, uma vez que se referem a institutos distintos. O Controle Administrativo é todo aquele que exerce o Executivo, assim como os órgãos internos dos demais Poderes (Legislativo ou Judiciário) exercem sobre suas atividades. Por outro lado, o Controle da Administração compreende o monitoramento tanto interno quanto externo das atividades da Administração Pública. Ou seja, o controle interno (ou administrativo) também é exercido pelo Legislativo e Judiciário em relação às suas estruturas internas (autotutela). Resumidamente, é aquele exercido sobre qualquer entidade da Administração Pública por hierarquia (dentro da própria pessoa jurídica), por tutela (do Executivo sobre entidade da administração Indireta ou descentralizada), fundado na autotutela administrativa (poder de revisão de seus próprios atos) ${ }^{26}$.

\footnotetext{
${ }^{25}$ FRANÇA, Philip Gil. O Controle da Administração Pública. 2. ed. São Paulo: Rev.Tribunais, 2010. p. 80.

${ }^{26}$ ARAUJO, EDMIR NETTO DE. Curso de Direito Administrativo. 5. ed. São Paulo: Saraiva, 2010. p. 1184.
} 
Pela Súmula 473, “A Administração pode anular seus próprios atos, quando eivados de vícios que os tornem ilegais, porque deles não se originam direitos; ou revogá-los, por motivo de conveniência ou oportunidade, respeitados os direitos adquiridos, e ressalvada, em todos os casos, a apreciação judicial".

Também a Constituição Federal de 1.988 contemplou o controle interno, nos termos do art. 74 , in verbis:

Art. 74. Os Poderes Legislativo, Executivo e Judiciário manterão, de forma integrada, sistema de controle interno com a finalidade de:

I - avaliar o cumprimento das metas previstas no plano plurianual, a execução dos programas de governo e dos orçamentos da União;

II - comprovar a legalidade e avaliar os resultados, quanto à eficácia e eficiência, da gestão orçamentária, financeira e patrimonial nos órgãos e entidades da administração federal, bem como da aplicação de recursos públicos por entidades de direito privado;

III - exercer o controle das operações de crédito, avais e garantias, bem como dos direitos e haveres da União;

IV - apoiar o controle externo no exercício de sua missão institucional.

$\S 1^{\circ}$ - Os responsáveis pelo controle interno, ao tomarem conhecimento de qualquer irregularidade ou ilegalidade, dela darão ciência ao Tribunal de Contas da União, sob pena de responsabilidade solidária.

$\S 2^{\circ}$ - Qualquer cidadão, partido político, associação ou sindicato é parte legítima para, na forma da lei, denunciar irregularidades ou ilegalidades perante o Tribunal de Contas da União.

O ponto de maior importância nesse tipo de controle é admitir-se que o poder de fiscalizar e reavaliar seus atos ocorre no interior da mesma estrutura de Poder. Ou seja, denomina-se Controle Interno porque o controlador e o controlado fazem parte da mesma estrutura organizacional ${ }^{27}$.

De acordo com Elcio Trujillo ${ }^{28}$ :

O princípio do controle administrativo ou tutela, tem vinculação com a indisponibilidade dos interesses púbicos. $\mathrm{O}$ Estado, através da Administração, procede a persecução de interesses que consagrou como pertinentes a si próprio. A implementação deles é feita pelo próprio Estado, mediante os diversos órgãos da Administração.

Não é só o Executivo que promove o controle interno em relação a seus órgãos; também os Poderes Legislativo e Judiciário, em relação a suas próprias estruturas administrativas (autotutela) o fazem, uma vez que também exercem função administrativa, dentro dos limites de suas atribuições .

\footnotetext{
${ }^{27}$ No mesmo sentido DIÓGENES GASPARINI. p. 548 e CARVALHO FILHO, José dos Santos. Manual de Direito Administrativo. 25. ed.São Paulo: Atlas, 2012. p. 935.

${ }^{28}$ TRUJILLO, Elcio. Responsabilidade do Estado por ato Lícito. São Paulo:LED-Editora do Direito,1996.,p. 91.
} 
Muito embora a doutrina trate frequentemente de mecanismos de controle (interno e externo) do Poder Executivo, vale lembrar que a Emenda Constitucional $n^{\circ}$ 45/04 criou como forma de controle externo para o Poder Judiciário o Conselho Nacional de Justiça, que se revela como órgão independente, cuja função é fiscalizar e propor políticas públicas para o Poder Judiciário, controlar suas atividades administrativa e financeira, e fazer o controle ético-disciplinar de seus membros.

O Controle Administrativo ${ }^{29}$ apresenta várias finalidades suscitadas pela doutrina. Controle Administrativo exercido de Ofício é o poder de fiscalização e correção que a Administração Pública (em sentido amplo) exerce sobre sua própria atuação, sob os aspectos de legalidade e mérito, por iniciativa própria ou mediante provocação. Na primeira hipótese, pode decorrer de: a) fiscalização hierárquica, b) supervisão superior, c) controle financeiro, d) pareceres vinculantes, e) ouvidoria.

Controle Administrativo exercido por provocação é outra hipótese de controle interno ou administrativo, e pode ocorrer por: a) exercício do direito de petição, b) pedido de reconsideração, c) reclamação administrativa, d) recurso administrativo.

O Estado é o guardião da legalidade, e por isso seus agentes têm o poder-dever de investigar as irregularidades que lhes são apontadas e recompor a legalidade. A denúncia formal e assinada por quem quer que seja, dirigida à autoridade, está assentada no texto constitucional (CF, art. $5^{\circ}, \mathrm{XXXIV}, a$ - direito de petição), e não vincula o signatário da medida (salvo falsa imputação), que não precisa ter interesse direto na correção do ato ou situação apontados.

De acordo com os ensinamentos de Dromi ${ }^{30}$, observa-se que o controle da Administração, ou intraorgânicos, como ele chama, tem por finalidade atestar a legitimidade e oportunidade da forma e o fim da atuação pública, como elementos de constatação da correspondência entre "antecedente e consequente", assim como "forma prevista e fim proposto", e com "forma e finalidade realizada".

O controle é, simultaneamente, uma prerrogativa e um dever, levando-se em conta a obrigatoriedade que implica seu exercício e sua natureza integralizadora a uma função estatal, de conteúdo jurídico. É um poder-dever estruturado sobre a ideia de tutela, cuidado e

\footnotetext{
${ }^{29}$ Odete Medauar critica a expressão controle administrativo afirmando que esta terminologia merece reparos, ante a possibilidade de associação do vocábulo "administrativo" a fiscalizações exercidas pela Administração Pública, o que não corresponde à acepção de controle exercido sobre si própria. In MEDAUAR, Odete. Controle da Administração Pública. 2. ed. São Paulo: Revista dos Tribunais, 2012. p. 48.
}

${ }^{30}$ DROMI, Roberto. Derecho Administrativo. 10. ed. Buenos Aires: Ciudad Argentina, 2004. p. 172. 
salvaguarda da ordem jurídica, que adquire uma importância fundamental dentro do Estado delineado pelo constitucionalismo moderno ${ }^{31}$.

Aquele que administra tem dever jurídico de dar conta de sua gestão e de responsabilizar-se por seus atos, nos exatos termos da noção de controle. Ou seja, de um lado pedir conta (controlar) e responder ou prestar contas (ser controlado) de outro lado.

Os meios de controle, segundo Hely Lopes Meirelles ${ }^{32}$, de modo genérico, são bipartidos em fiscalização hierárquica e recursos administrativos, embora a lei possa especificar outras modalidades mais adequadas, para certos órgãos, entes ou atividades da Administração Direta ou Indireta, como, por exemplo a prestação de contas.

O Decreto-lei 200, de 25 de fevereiro de 1.967, dispondo sobre a reforma administrativa federal, incluiu o controle como um dos seus princípios fundamentais, nos termos do art. $6^{\circ}$, inciso $\mathrm{V}$.

Resumidamente, no nosso entendimento, o Controle de Administração Pública pode ser interno ou externo: interno quando for realizado por meio de instrumentos que se encontram dentro de sua estrutura, e externo quando realizado por instrumentos ou órgãos estranhos aos seus quadros.

\subsubsection{Recursos administrativos}

Recurso administrativo é todo o meio que os administrados podem utilizar para provocar o reexame do ato editado pela própria Administração Pública, pela mesma autoridade ou por outra hierarquicamente superior. Alguns autores consideram o pedido de reconsideração uma espécie de recurso administrativo, uma vez que o pedido de reconsideração se consubstancia em pedido de reexame de uma decisão e é dirigido à mesma autoridade que a editou. Observemos a Lei 8.666/93, que trata de licitações e contratos administrativos, inserindo o pedido de reconsideração da declaração de idoneidade entre os recursos administrativos, nos termos do artigo 109, in verbis:

Art. 109. Dos atos da Administração decorrentes da aplicação desta Lei cabem:

\footnotetext{
${ }^{31}$ DROMI, Roberto. Derecho Administrativo. 10. ed. Buenos Aires: Ciudad Argentina, 2004. p. 172.

${ }^{32}$ MEIRELLES, Hely Lopes. Direito Administrativo Brasileiro. 37. ed. São Paulo: Malheiros, 2011. p. 720.
} 
III - pedido de reconsideração, de decisão de Ministro de Estado, ou

Secretário Estadual ou Municipal, conforme o caso, na hipótese do $\S 4^{\circ}$ do art. 87 desta Lei, no prazo de 10 (dez) dias úteis da intimação do ato.

Assim como o pedido de reconsideração, o recurso hierárquico e a revisão também seriam classificados como espécies, cujo gênero seria o Recurso Administrativo em sentido amplo.

Os Recursos administrativos podem ter efeito suspensivo ou devolutivo. Devolutivo é o efeito normal de todos os recursos, pois remete de volta o exame da matéria à autoridade competente para decidir. Já o efeito suspensivo, como o próprio nome diz, suspende os efeitos do ato até a decisão do recurso, e só existe quando a lei o prevê expressamente, ou seja, no silêncio da lei o recurso é recebido apenas com efeito devolutivo ${ }^{33}$.

\subsubsection{A figura do ombudsman e as ouvidorias}

Baseados na figura do Ombudsman, que se consubstancia em uma das formas de controle externo, foram criados órgãos ou autoridades internas, inseridos na estrutura da Administração Pública, intitulados Ouvidorias.

Para compreender a figura do Ombudsman é necessário conhecer sua origem, uma vez que se trata de mecanismo muito utilizado na Europa continental, como figura Auxiliar dos Parlamentos, consistente em designação, por estes, de agente fiscalizador para o controle dos diversos setores da Administração. Originário da Suécia (para alguns, sua origem veio da Noruega), é dotado de poderes de persuasão e influência (mas não de anulação/revogação ou penalização) quanto à autoridade administrativa fiscalizada, e poderes de proposta em relação à solução de problemas apontados por particulares em queixas, reclamações ou representações.

A ele se atribuem também várias prerrogativas que lhe conferem respeitabilidade e imparcialidade, além da indispensável independência em relação ao Executivo.

\footnotetext{
${ }^{33}$ Nesse sentido, EDMIR NETTO DE ARAUJO. Curso de Direito Administrativo. 5. ed. São Paulo: Saraiva, 2010. p. 1186.
} 
Essa prática se propagou, merecendo destaque a instituição do "Ombudsman europeu" (Provedor de Justiça Europeu), com âmbito em toda a União Europeia, como "guardião" do Código Europeu de Boa Conduta Administrativa.

O controle dos atos administrativos na França é feito pela própria administração pública, que, além de exercer a autotutela, julga os litígios decorrentes de suas atividades. $\mathrm{O}$ Contentieux Administratif influenciou diversos países na Europa e nas Américas, como Colômbia, Equador, Uruguai e Venezuela. Com o provável intuito de subtrair, do exame do judiciário, lesões causadas pela Administração, os franceses separaram duas ordens de jurisdição, vejamos.

A primeira é a jurisdição do Poder Judiciário, formada por juízos e tribunais comuns e ordinários até a Corte de Cassação.

A segunda é a jurisdição Administrativa, formada por juízos e tribunais administrativos até o Conselho de Estado. Dentre esses tribunais, encontra-se o Tribunal de Conflitos, uma comissão paritária, do tipo arbitral e jurisdicional, encarregada de solucionar os conflitos de atribuição entre as ordens judiciária e administrativa, prolatando "sentenças de conflito", atributivas ou declaratórias de competência.

Ainda na França, dentre as autoridades independentes, podemos citar: Le Médiateur de la République, cuja natureza encontra-se explicitada nas lições de Dominique $\operatorname{Turpin}^{34}$ :

Institué par la loi du 3 janvier 1973, il est charge de recevoir les réclamations relatives au functionnement des administrations et services publics, sur saisine - via um parlementaire - d'un particulier ou d'une personne morale (cf. le décret du 31 janvier 2008 réorganisant ses services), ainsi que de formuler des propositions de réformé. Il est assité de prés de 300 délégués départementaux que réglent les réclamations les plus simples $(90 \%)^{35}$.

Turpin destaca, ainda, a figura do Défenseur des droits:

Inspiré par les "Ombudsmen" scandinaves et le "Defenseur du peuple" espagnol, il veillera "au respect des droits et libertés par les administrations de l'État, les collectivités territoriales, les établissements publics, ainsi que tout organisme investi d'une mission de servisse public à l'égard duquel la

\footnotetext{
${ }^{34}$ TURPIN, Dominique. Contentieux Administratif. 5. ed. Paris: Hachette Sipérieur, 2010. p. 8.

35 "Instituído pela lei de 3 de janeiro de 1973, é encarregado de receber as reclamações relativas ao funcionamento da Administração e serviços públicos, sob provocação - via um parlamentar - de um particular ou de uma pessoa jurídica (cf. o decreto de 31 de janeiro de 2008 que reorganizou os serviços), assim como formular propostas de reforma. Ele é assistido por 300 delegados departamentais que analisam as reclamações mais simples (90\%).” (tradução livre).
} 
loi organique (à venir) lui attribue des compétences" (article 71-1 § 1er. de la Constitution) sur saisine de toute personne s'estimant lésée ou d'office. Il disposera d'un pouvoir de recommandation, d'injonction, de transaction et $\mathrm{d}^{\prime}$ investigation, il sera assité de deux collègues de trois membres ${ }^{36}$.

Nos domínios do direito inglês, encontramos ideia análoga à figura do Ouvidor ou Ombusdman. Ao tempo de Jacques I, havia a Corte do Banco do Rei, uma espécie de corporação encarregada de atender, em nome da Coroa, às reclamações contra os funcionários do próprio rei, emitindo writs, que os servos da Coroa eram obrigados a respeitar. No reinado de Carlos I, surgiu a Câmara Estrelada, outro órgão que aparece como elemento de amparo do súdito contra os funcionários do Estado; após sua extinção, foram criadas as corporações dos condados, com grande poder sobre os atos da Administração ${ }^{37}$.

\subsection{CONTROLE EXTERNO DA ADMINISTRAÇÃO}

A separação das funções do Estado constitui medida salutar que visa a limitar o poder pelo próprio poder. Dessa forma, dividem-se as competências entre os diversos órgãos do Estado e lhe conferem prerrogativas para que atuem de maneira independente sem que um se sobreponha ao outro. É o que se chama checks and balance, ou "sistema de freios e contrapesos" ${ }^{\prime 3}$, que permite a existência de uma espécie de controle que um órgão pode exercer sobre o outro sem, contudo, estar imune a esse mesmo controle.

O controle externo do Estado é aquele exercido, nos termos constitucionais, por outro Poder, diverso daquele que é controlado; abrange, além do controle parlamentar direto (pelo Poder Legislativo) e do exercido pelos Tribunais de Contas (que são órgãos auxiliares do Poder Legislativo), também o controle jurisdicional, exercido pelo Poder Judiciário.

\footnotetext{
${ }^{36}$ TURPIN, Dominique. Contentieux Administratif. 5. ed. Paris: Hachette Sipérieur, 2010. p. 9. "Inspirado no 'Ombudsmen' escandinavo e no "Defensor do Povo" espanhol, irá assegurar "o respeito aos direitos e liberdades das Administrações do Estado, as coletividades territoriais, as instituições públicas, bem como todo organismo investido de uma missão de serviço público para os quais a lei orgânica (em breve) lhe atribui as competências" (art. 71-1, § $1^{\circ}$ da Constituição) sob provocação de qualquer pessoa lesada ou seu representante legal. Ele terá como atribuição recomendar, propor ações judiciais e investigações, será acompanhado de mais dois colegas. (tradução livre).

${ }^{37}$ FAGUNDES . M. Seabra. O Controle dos Atos Administrativos pelo Poder Judiciário. 7. ed. Rio de Janeiro: Forense, 2005. p. 124-125

${ }^{38}$ FERREIRA FILHO, Manoel Gonçalves. Curso de Direito Constitucional apud ARAUJO, Edmir Netto de. Curso de Direito Administrativo. 5. ed. São Paulo: Saraiva, 2010. p. 1180.
} 
No âmbito de monitoramento externo, identificamos, também, o controle popular ou social como forma mais democrática de fiscalização por parte da comunidade, que por meio das Ouvidorias exerce pressão sobre os órgãos governamentais, no sentido de fazer valer suas reivindicações. A população também pode participar e influenciar na condução dos assuntos públicos por meio de instrumentos como: a) ação popular; b) consultas públicas; c) audiências públicas; d) plebiscito; e, ainda, e) referendo.

No que diz respeito à consulta pública e à audiência popular para o debate de questões relacionadas a interesses coletivos, já há previsão legal nos termos da lei 9.784, 29 de janeiro de 1999, que regula o processo administrativo no âmbito da Administração Pública Federal, em seus arts. 31 e 32 , in verbis:

Art. 31. Quando a matéria do processo envolver assunto de interesse geral, o órgão competente poderá, mediante despacho motivado, abrir período de consulta pública para manifestação de terceiros, antes da decisão do pedido, se não houver prejuízo para a parte interessada.

$\S 1^{\circ}$ A abertura da consulta pública será objeto de divulgação pelos meios oficiais, a fim de que pessoas físicas ou jurídicas possam examinar os autos, fixando-se prazo para oferecimento de alegações escritas.

$\S 2^{\underline{o}} \mathrm{O}$ comparecimento à consulta pública não confere, por si, a condição de interessado do processo, mas confere o direito de obter da Administração resposta fundamentada, que poderá ser comum a todas as alegações substancialmente iguais.

Art. 32. Antes da tomada de decisão, a juízo da autoridade, diante da relevância da questão, poderá ser realizada audiência pública para debates sobre a matéria do processo.

No que se refere a este tema, importante lembrar que vários Municípios brasileiros têm implementado a prática de realização do orçamento participativo, oportunidade em que a população discute quais são as prioridades a serem contempladas pelo orçamento público.

Além dos exemplos mencionados, podemos, ainda, apontar:

(1) $\mathrm{O}$ art. $2^{\circ}$, II, do Estatuto da Cidade, que prevê a obrigatoriedade da gestão democrática nos planos de desenvolvimento urbano, in verbis:

Art. $2^{\circ}$ - Art. $2^{\circ}$ A política urbana tem por objetivo ordenar o pleno desenvolvimento das funções sociais da cidade e da propriedade urbana, mediante as seguintes diretrizes gerais:

II. gestão democrática por meio da participação da população e de associações representativas dos vários segmentos da comunidade na formulação, execução e acompanhamento de planos, programas e projetos de desenvolvimento urbano;

(2) O artigo 37, § $3^{\circ}$, da Constituição Federal de 1988, que determina a edição de lei que discipline formas de participação do usuário na Administração: 
Art. $37-$

$\S 3^{\circ}$ - A lei disciplinará as formas de participação do usuário na administração pública direta e indireta, regulando especialmente:

I - as reclamações relativas à prestação dos serviços públicos em geral, asseguradas a manutenção de serviço de atendimento ao usuário e a avaliação periódica, externa e interna, da qualidade dos serviços;

II - o acesso dos usuários a registros administrativos e a informações sobre atos de governo, observado o disposto no art. $5^{\circ}$, X e XXXIII;

III - a disciplina da representação contra o exercício negligente ou abusivo de cargo, emprego ou função na administração pública.

(3) O artigo 198, III, da Constituição Federal atual, que prevê a participação da comunidade no serviço de saúde:

Art. 198 - As ações e serviços públicos de saúde integram uma rede regionalizada e hierarquizada e constituem um sistema único, organizado de acordo com as seguintes diretrizes:

III - participação da comunidade.

(4) O artigo 194, VII, da Seguridade Social, no qual é mencionado o caráter democrático e de cogestão:

Art. 194 - A seguridade social compreende um conjunto integrado de ações de iniciativa dos Poderes Públicos e da sociedade, destinadas a assegurar os direitos relativos à saúde, à previdência e à assistência social.

Parágrafo único. Compete ao Poder Público, nos termos da lei, organizar a seguridade social, com base nos seguintes objetivos:

VII - caráter democrático e descentralizado da administração, mediante gestão quadripartite, com participação dos trabalhadores, dos empregadores, dos aposentados e do Governo nos órgãos colegiados.(Redação dada pela Emenda Constitucional nº 20, de 1998).

(5) $\mathrm{O}$ artigo $2^{\circ}$, inciso $\mathrm{X}$, da Lei $\mathrm{n}^{\mathrm{o}} 11.445$, de 05 de janeiro de 2007 que prevê o controle social dos serviços públicos de saneamento básico, sendo este considerado: conjunto de mecanismos e procedimentos que garantem à sociedade informações, representações técnicas e participações nos processos de formulação de políticas, de planejamento e de avaliação relacionados aos serviços públicos de saneamento básico.

Art. $2^{\circ}$ - Os serviços públicos de saneamento básico serão prestados com base nos seguintes princípios fundamentais:

$\mathrm{X}$ - controle social; 


\subsubsection{Controle da administração pelo Ministério Público}

Não há como negar que o Ministério Público exerce controle efetivo sobre a Administração Pública: a sua atuação, que é evidenciada pela instauração de Inquéritos Civis, a emissão de recomendação e relatórios, a tomada de compromisso de ajustamento de conduta e o acompanhamento de processos administrativos demonstram a forte atuação do Ministério Público e de modo proficiente a existência dessa modalidade de controle.

A fundamentação legal de sua função de monitoramento da Administração Pública encontra-se esculpida no caput do artigo 127 e no artigo 129, da Constituição Federal de 1988, nos seguintes termos:

Art. 127. O Ministério Público é instituição permanente, essencial à função jurisdicional do Estado, incumbindo-lhe a defesa da ordem jurídica, do regime democrático e dos interesses sociais e individuais indisponíveis.

[...]

Art. 129. São funções institucionais do Ministério Público:

I - promover, privativamente, a ação penal pública, na forma da lei;

II - zelar pelo efetivo respeito dos Poderes Públicos e dos serviços de relevância pública aos direitos assegurados nesta Constituição, promovendo as medidas necessárias a sua garantia;

III - promover o inquérito civil e a ação civil pública, para a proteção do patrimônio público e social, do meio ambiente e de outros interesses difusos e coletivos;

IV - promover a ação de inconstitucionalidade ou representação para fins de intervenção da União e dos Estados, nos casos previstos nesta Constituição; $\mathrm{V}$ - defender judicialmente os direitos e interesses das populações indígenas; VI - expedir notificações nos procedimentos administrativos de sua competência, requisitando informações e documentos para instruí-los, na forma da lei complementar respectiva;

VII - exercer o controle externo da atividade policial, na forma da lei complementar mencionada no artigo anterior;

VIII - requisitar diligências investigatórias e a instauração de inquérito policial, indicados os fundamentos jurídicos de suas manifestações processuais;

IX - exercer outras funções que lhe forem conferidas, desde que compatíveis com sua finalidade, sendo-lhe vedada a representação judicial e a consultoria jurídica de entidades públicas.

Não obstante a Constituição vigente ter atribuído um rol de competências ao Ministério Público, o que representa momento institucional significante, vale observar que desde as Ordenações Manuelinas (1.521) e as Filipinas (1.603) já havia referência ao Promotor de Justiça como um fiscal da lei. A Carta Magna de 1824 não trouxe qualquer 
dispositivo sobre o Ministério Público, entretanto uma Lei Comum de 1890 lhe atribuiu caráter de Instituição $^{39}$. Quanto à Constituição Federal de 1891, esta não cita o MP como órgão.

Foi a Carta Magna de 1.934 a primeira a lhe dar tratamento, incluindo-o, nos termos do artigo 95 e 98, no capítulo VI, entre os órgãos de cooperação nas atividades governamentais.

Art 95 - O Ministério Público será organizado na União, no Distrito Federal e nos Territórios por lei federal, e, nos Estados, pelas leis locais.

$\S 1^{\circ}$ - O Chefe do Ministério Público Federal nos Juízos comuns é o Procurador-Geral da República, de nomeação do Presidente da República, com aprovação do Senado Federal, dentre cidadãos com os requisitos estabelecidos para os Ministros da Corte Suprema. Terá os mesmos vencimentos desses Ministros, sendo, porém, demissível ad nutum .

$2^{\circ}$ - Os Chefes do Ministério Público no Distrito Federal e nos Territórios serão de livre nomeação do Presidente da República dentre juristas de notável saber e reputação ilibada, alistados eleitores e maiores de 30 anos, com os vencimentos dos Desembargadores.

$\S 3^{\circ}$ - Os membros do Ministério Público Federal que sirvam nos Juízos comuns serão nomeados mediante concurso e só perderão os cargos, nos termos da lei, por sentença judiciária, ou processo administrativo, no qual lhes será assegurada ampla defesa.

Art 96 - Quando a Corte Suprema declarar inconstitucional qualquer dispositivo de lei ou ato governamental, o Procurador Geral da República comunicará a decisão ao Senado Federal para os fins do art. 91, n ${ }^{\circ} \mathrm{IV}$, e bem assim à autoridade legislativa ou executiva, de que tenha emanado a lei ou o ato.

Art 97 - Os Chefes do Ministério Público na União e nos Estados não podem exercer qualquer outra função pública, salvo o magistério e os casos previstos na Constituição. A violação deste preceito importa a perda do cargo.

Art 98 - O Ministério Público, nas Justiças Militar e Eleitoral, será organizado por leis especiais, e só terá, na segunda, as incompatibilidades que estas prescrevem.

Nessa toada, a Lei Maior de 1.946 prestigiou o órgão, fazendo referência sobre a Instituição, em título próprio, conforme se depreende nos artigos 125 a 128, desvinculando-o de qualquer outro Poder da União.

Art. 125 - A lei organizará o Ministério Público da União, junto à Justiça Comum, à Militar, à Eleitoral e à do Trabalho.

Art 126 - O Ministério Público federal tem por Chefe o Procurador-Geral da República. O Procurador, nomeado pelo Presidente da República, depois de aprovada a escolha pelo Senado Federal, dentre cidadãos com os requisitos indicados no artigo 99, é demissível ad nutum .

Parágrafo único - A União será representada em Juízo pelos Procuradores da República, podendo a lei cometer esse encargo, nas Comarcas do interior, ao Ministério Público local.

\footnotetext{
${ }^{39}$ MEDAUAR, Odete. Controle da Administração Pública. 2. ed. São Paulo: Revista dos Tribunais, 2012. p. 165-166.
} 
Art. 127 - Os membros do Ministério Público da União, do Distrito Federal e dos Territórios ingressarão nos cargos iniciais da carreira mediante concurso. Após dois anos de exercício, não poderão ser demitidos senão por sentença judiciária ou mediante processo administrativo em que se lhes faculte ampla defesa; nem removidos a não ser mediante representação motivada do Chefe do Ministério Público, com fundamento em conveniência do serviço.

Art. 128 - Nos Estados, a Ministério Público será também organizado em carreira, observados os preceitos do artigo anterior e mais o princípio de promoção de entrância a entrância.

A Constituição Federal de 1.967 reservou uma Seção ao Ministério Público, dos artigos 137 a 139:

Art 137 - A lei organizará o Ministério Público da União junto aos Juízes e Tribunais Federais.

Art 138 - O Ministério Público Federal tem por Chefe o Procurador-Geral da República, o qual será nomeado pelo Presidente da República, depois de aprovada a escolha pelo Senado Federal, dentre cidadãos com os requisitos Indicados no art. $113, \S 1^{\circ}$.

$\S 1^{\circ}$ - Os membros do Ministério Público da União, do Distrito Federal e dos Territórios ingressarão nos cargos iniciais de carreira, mediante concurso público de provas e títulos. Após dois anos de exercício, não poderão ser demitidos senão por sentença judiciária, ou em virtude de processo administrativo em que se lhes faculte ampla defesa; nem removidos, a não ser mediante representação do Procurador-Geral, com fundamento em conveniência do serviço.

$\S 2^{\circ}$ - A União será representada em Juízo pelos Procuradores da República, podendo a lei cometer esse encargo, nas Comarcas do interior, ao Ministério Público local.

Art 139 - O Ministério Público dos Estados será organizado em carreira, por lei estadual, observado o disposto no parágrafo primeiro do artigo anterior.

Parágrafo único - Aplica-se aos membros do Ministério Público o disposto no art. $108, \S 1^{\circ}$, e art. $136, \S 4^{\circ}$.

A Emenda Constitucional de 1/1.969 manteve os dispositivos legais da Constituição anterior.

Essa breve retrospectiva acerca da trajetória do Ministério Público se presta para que possamos vislumbrar a evolução da referida Instituição, no decorrer da história brasileira, e o quanto ganhou relevo ao longo do tempo.

O Ministério Público, na qualidade de instituição essencial à função jurisdicional do Estado, atuando em ações que geram o Controle da Administração Pública, possui, entre as suas atribuições elencadas no artigo 129 da Constituição Federal, a legitimidade para celebrar ajustes de conduta, obrigando a Administração a adequar-se a determinados comportamentos, aos preceitos legais; possui legitimidade para propor, privativamente, ação civil pública, hipótese em que a celeuma é submetida à apreciação do Judiciário. 


\subsubsection{Controle legislativo (ou parlamentar)}

O controle legislativo (ou parlamentar) é exercido pelas Casas Legislativas (Congresso Nacional, Senado Federal, Câmara dos Deputados, Assembleias Legislativas, Câmara Distrital e Câmara dos Vereadores) e se evidencia em grande variedade de atos, poderes, competências e aprovações, atribuídos pelo ordenamento jurídico para tornar efetiva a submissão ao exame, especialmente com lastro no art. 49, X, da Constituição Federal, que dá competência ao Congresso Nacional para fiscalizar e controlar os atos do Poder Executivo, inclusive os da Administração indireta.

O monitoramento do Legislativo é efetivamente exercido pelo controle parlamentar direto (casas legislativas), e pelos órgãos auxiliares do Poder Legislativo (Tribunais de Contas), cujo fundamento eminentemente constitucional encontra guarida no artigo 49, inciso X da Constituição federal de 1.988.

O Poder Legislativo, no desempenho da atividade verificadora, pode instaurar Comissões Parlamentares de Inquérito - CPI's; proceder a pedidos de informações; convocar autoridades para esclarecimentos; suspender e destituir ("impeachment") o Presidente da República; e exercer a fiscalização financeira, contábil, operacional e orçamentária sobre atos e contratos dos demais Poderes, com o apoio consultivo do Tribunal de Contas.

O Controle externo exercido pelos Tribunais de Contas e Congresso Nacional está esculpido nos artigos 70 e 71, da Carta Magna, nos seguintes termos:

Art. 70. A fiscalização contábil, financeira, orçamentária, operacional e patrimonial da União e das entidades da administração direta e indireta, quanto à legalidade, legitimidade, economicidade, aplicação das subvenções e renúncia de receitas, será exercida pelo Congresso Nacional, mediante controle externo, e pelo sistema de controle interno de cada Poder.

Parágrafo único. Prestará contas qualquer pessoa física ou jurídica, pública ou privada, que utilize, arrecade, guarde, gerencie ou administre dinheiros, bens e valores públicos ou pelos quais a União responda, ou que, em nome desta, assuma obrigações de natureza pecuniária.

Art. 71. O controle externo, a cargo do Congresso Nacional, será exercido com o auxílio do Tribunal de Contas da União, ao qual compete:

I - apreciar as contas prestadas anualmente pelo Presidente da República, mediante parecer prévio que deverá ser elaborado em sessenta dias a contar de seu recebimento;

II - julgar as contas dos administradores e demais responsáveis por dinheiros, bens e valores públicos da administração direta e indireta, incluídas as fundações e sociedades instituídas e mantidas pelo Poder 
Público federal, e as contas daqueles que derem causa a perda, extravio ou outra irregularidade de que resulte prejuízo ao erário público;

III - apreciar, para fins de registro, a legalidade dos atos de admissão de pessoal, a qualquer título, na administração direta e indireta, incluídas as fundações instituídas e mantidas pelo Poder Público, excetuadas as nomeações para cargo de provimento em comissão, bem como a das concessões de aposentadorias, reformas e pensões, ressalvadas as melhorias posteriores que não alterem o fundamento legal do ato concessório;

IV - realizar, por iniciativa própria, da Câmara dos Deputados, do Senado Federal, de Comissão técnica ou de inquérito, inspeções e auditorias de natureza contábil, financeira, orçamentária, operacional e patrimonial, nas unidades administrativas dos Poderes Legislativo, Executivo e Judiciário, e demais entidades referidas no inciso II;

$\mathrm{V}$ - fiscalizar as contas nacionais das empresas supranacionais de cujo capital social a União participe, de forma direta ou indireta, nos termos do tratado constitutivo;

VI - fiscalizar a aplicação de quaisquer recursos repassados pela União mediante convênio, acordo, ajuste ou outros instrumentos congêneres, a Estado, ao Distrito Federal ou a Município;

VII - prestar as informações solicitadas pelo Congresso Nacional, por qualquer de suas Casas, ou por qualquer das respectivas Comissões, sobre a fiscalização contábil, financeira, orçamentária, operacional e patrimonial e sobre resultados de auditorias e inspeções realizadas;

VIII - aplicar aos responsáveis, em caso de ilegalidade de despesa ou irregularidade de contas, as sanções previstas em lei, que estabelecerá, entre outras cominações, multa proporcional ao dano causado ao erário;

IX - assinar prazo para que o órgão ou entidade adote as providências necessárias ao exato cumprimento da lei, se verificada ilegalidade;

$\mathrm{X}$ - sustar, se não atendido, a execução do ato impugnado, comunicando a decisão à Câmara dos Deputados e ao Senado Federal;

XI - representar ao Poder competente sobre irregularidades ou abusos apurados.

$\S 1^{\circ}$ - No caso de contrato, o ato de sustação será adotado diretamente pelo Congresso Nacional, que solicitará, de imediato, ao Poder Executivo, as medidas cabíveis.

$\S 2^{\circ}$ - Se o Congresso Nacional ou o Poder Executivo, no prazo de noventa dias, não efetivar as medidas previstas no parágrafo anterior, o Tribunal decidirá a respeito.

$\S 3^{\circ}$ - As decisões do Tribunal de que resulte imputação de débito ou multa terão eficácia de título executivo.

$\S 4^{\circ}-\mathrm{O}$ Tribunal encaminhará ao Congresso Nacional, trimestral e anualmente, relatório de suas atividades (grifos nossos).

Lúcia Valle Figueiredo ${ }^{40}$ trazendo a lume a amplitude do controle não apenas na declaração expressa de que todos aqueles que manipulam recursos públicos a ele se submetem, bem como na abrangência desse controle, e palmilhando o texto constitucional, constata que "nada ficou ao largo da fiscalização".

\footnotetext{
${ }^{40}$ FIGUEIREDO, Lúcia Valle. Curso de Direito Administrativo. 7. ed. São Paulo: Malheiros, 2004. p. 356-357.
} 


\subsubsection{Controle pelo Judiciário}

O controle externo da Administração também pode ser exercido pelo Poder Judiciário, classificando-se em preventivo ou corretivo, ou ainda decorrente de ações constitucionais: habeas corpus, habeas data, mandado de segurança, mandado de injunção, ação popular e ação civil pública.

Segundo Jean Waline ${ }^{41}$,

Ce qui caractérise le droit administratif c'est la très grande importance qu'il accorde au contrôle juridictionnel c'est-à-dire au contrôle de l'Administration par un juge spécialisé, le juge administratif, qui a le pouvoir d'annuler les décisions illégales de l'Administration. Au fonde, on considère que si l'Administration manque au Droit c'est au juge administratif qu'il revient de la sanctionner. Pour cela les administrés disposent d' un certain nombre de recours, l'un de ceus-ci, le recours pour excès de pouvoir ayant une importance toute particulière. ${ }^{42}$

A finalidade essencial e característica do controle jurisdicional é a proteção do indivíduo em face da Administração Pública ${ }^{43}$.

Nos dizeres de Lúcia Valle Figueiredo ${ }^{44}$,

O controle externo pelo Poder Judiciário, nesta Constituição de 1988, foi aumentado e fortalecido. Dizemos aumentado porque, agora, não se limita o exame do Judiciário às lesões de direito. A mera ameaça já fundamenta a revisão ou correção judicial.

A edição do ato administrativo (ou prática de atos materiais) pelo agente do Estado poderá, ocasionalmente, não estar de acordo com o modelo legal ou com o interesse público, lesando, assim, direitos ou interesses do administrado, o qual, em certos casos, poderá recorrer ao Poder Judiciário para restabelecer o equilíbrio da ordem jurídica lesado com a medida e, assim, recolocar as coisas no "status quo ante".

\footnotetext{
${ }^{41}$ WALINE, Jean. Droit Administratif. 23. ed. Paris: Dalloz, 2010. p. 30.

${ }^{42} \mathrm{O}$ que caracteriza o direito administrativo é a grande importância que atribui ao Judiciário, ou seja, o controle dos Administradores por um juiz especializado, o juiz de direito administrativo, que tem o poder de cancelar decisões ilegais da Administração. Basicamente, considera-se que se a Administração falha é de responsabilidade do juiz administrativo aplicar a sanção. Para isso, os administrados dispõem de recursos, um deles é o recurso por abuso de poder, que tem importância especial (tradução livre).
}

${ }^{43}$ FAGUNDES, Miguel Seabra. O Controle dos Atos Administrativos pelo Poder Judiciário. 7. ed. Rio de Janeiro: Forense, 2005. p. 135.

${ }^{44}$ FIGUEIREDO, Lúcia Valle. Curso de Direito Administrativo. 7. ed. São Paulo: Malheiros, 2004. p. 358. 
O fundamento do controle jurisdicional da atividade administrativa repousa no art. $5^{\circ}, \mathrm{XXXV}, \mathrm{CF} / 88$, segundo o qual nenhuma lesão ou ameaça a direito poderá ser subtraída ao exame do Poder Judiciário.

Para Celso Antonio Bandeira de $\mathrm{Mello}^{45}$ :

[...] o Poder Judiciário, a instância da parte interessada, controla, in concreto, a legitimidade dos comportamentos da Administração Pública, anulando suas condutas ilegítimas, compelindo-a àquelas que seriam obrigatórias e condenando-a a indenizar os lesados, quando for o caso. Diz o art. $5^{\circ}$, XXXV, da Constituição brasileira que "a lei não excluirá da apreciação do Poder Judiciário, lesão ou ameaça ao direito".

Conforme ensina Seabra Fagundes ${ }^{46}$, acompanhando o direito inglês é que melhor se pode compreender o ciclo evolutivo do controle jurisdicional sobre a Administração Pública, haja vista ter sido lá que se originou. Guilherme, o Conquistador, quando se ausentava do país, delegava ao Justiciar a regência do reino e a incumbência de administrar justiça em seu nome. Este foi o primeiro fato de missão julgadora.

\subsubsection{Unicidade e duplicidade de jurisdição}

A unicidade de jurisdição - ou o exercício da jurisdição administrativa pelo poder judiciário - é também conhecida como modelo Anglo-saxão, no qual o Judiciário tem conhecimento exclusivo do contencioso da Administração, o que possibilita o nivelamento entre a Administração e o administrado, para solução judicial de suas demandas. O desenvolvimento desse modelo acompanha a Evolução do Estado e do Direito Público Inglês, e a separação gradativa dos poderes.

[...] Em 1701, com o Act of settlement, se veda a demissão livre dos funcionários da Justiça, é aí que começa a existir, praticamente, o controle do Poder Administrativo por um órgão autônomo, mais tarde individualizado na estrutura política de todos os Estados com o nome de Poder Judiciário. Por isso se pode dizer que esboçar a história do controle jurisdicional da Administração Pública, por intermédio da jurisdição ordinária, é acompanhar a gradativa formação do Poder Judiciário como órgão autônomo na estrutura

\footnotetext{
${ }^{45}$ BANDEIRA DE MELlo, Celso Antonio. Curso de Direito Administrativo. 28. ed. São Paulo: Malheiros. 2011. p. 954-955.

${ }^{46}$ FAGUNDES, Miguel Seabra. O Controle dos Atos Administrativos pelo Poder Judiciário. 7. ed. Rio de Janeiro: Forense, 2005. p. 142.
} 
política do Estado, porque é exatamente através desse fenômeno que se efetiva, com nitidez, a sua aparição no mecanismo estatal ${ }^{47}$.

A função jurisdicional, que estava em estado latente, só aparece com nitidez, quando surge, dentro da Administração, uma separação de órgãos. Esse foi um processo gradativo de separação de funções que, de início, não eram claras nem definidas, de forma que havia funcionários que administravam propriamente e funcionários que resolviam as contendas.

Os atos da administração passaram a ser controlados pelo Poder Judiciário, que tem competência para julgar as contendas envolvendo a administração pública. Esse sistema de exame contencioso dos atos da Administração Pública pelos órgãos do Poder Judiciário é ainda hoje adotado na Grã-Bretanha, onde teve as suas raízes históricas.

De acordo com os ensinamentos de Edmir Netto de Araújo ${ }^{48}$, o controle, porém, não é exclusividade do Poder Judiciário. Existem, na Inglaterra, os "Tribunais especiais" "administrativos" (statutory tribuna) que designam genericamente jurisdições administrativas especializadas. Porém nem todos esses tribunais especializados são administrativos (cuidam também de outras matérias). Alguns não são criados por lei e outros tratam apenas de litígios entre proprietários e arrendatários de imóveis. Pode-se defini-los como "procedimentos quase judiciais", já que normalmente existe direito a recurso ao judiciário. Muitas vezes esses tribunais especiais servem apenas de filtro para descongestionar o judiciário.

Sob a influência do Direito inglês, cujo sistema de exame contencioso dos atos da Administração Pública pelos órgãos do Poder Judiciário é ainda hoje adotado na GrãBretanha, este foi seguido por outros países que adotaram esse modelo. É o caso dos Estados Unidos da América do Norte, conforme estabelecido no art. $2^{\circ}$, inciso III, da Constituição Federal $^{49}$.

Em 1.931, a Constituição belga o acolheu. Esse foi um acontecimento relevante a sua difusão, pois veio a ser posteriormente adotado, por inspiração do direito belga, na Itália com a lei $\mathrm{n}^{\mathrm{o}} 2.248$, de 20 de março de 1.865, e na Romênia, em 1.866. A Irlanda, na Constituição de 1.922 também deu ao Judiciário o controle exclusivo dos atos da

\footnotetext{
${ }^{47}$ FAGUNDES, Miguel Seabra. O Controle dos Atos Administrativos pelo Poder Judiciário. 7. ed. Rio de Janeiro: Forense, 2005. p. 143-144.

${ }^{48}$ ARAUJO, Edmir Netto. Curso de Direito Administrativo. 5. ed. São Paulo: Saraiva, 2010. p. 1280.

${ }^{49}$ FAGUNDES, Miguel Seabra. O Controle dos Atos Administrativos pelo Poder Judiciário. 7. ed. Rio de Janeiro: Forense, 2005. p. 146.
} 
Administração Pública. Igualmente, no México, este é o sistema acolhido ${ }^{50}$. Além de vários países de common law, também alguns de origem romanística sofrem a influência do modelo inglês.

Nos Estados Unidos da América, também existem muitos "tribunais administrativos" que concretizam a chamada justiça administrativa, por meio de procedimentos quase judiciais. Porém, não podem ser confundidos com o contencioso administrativo, que atua na França.

$\mathrm{Na}$ opinião de Edmir Netto de Araújo ${ }^{51}$, não se deve confundir os tribunais administrativos ingleses e norte-americanos com o contencioso administrativo francês, porque decisões daqueles, podem, em princípio, ser revistas pelos tribunais judiciários. Na justiça administrativa americana, assim como na inglesa, não há ordem judicial administrativa, autônoma e independente do Poder Judiciário comum: há somente órgãos administrativos quase-judiciais, relativamente autônomos em relação ao Poder Executivo (Administração) e adstritos ao Poder Judiciário comum pela via recursal.

O sistema de jurisdição dúplice, no qual há jurisdição específica para julgar os litígios decorrentes das atividades da Administração Pública, está pautado no exemplo clássico que é representado pelo sistema francês.

A origem da duplicidade de jurisdição deita raízes na época que sucedeu a revolução Francesa, no século XVIII, oportunidade em que ocorreram grandes convulsões sociais, e nos movimentos multitudinários, característicos do estado de exceção, em que ocorreram numerosas lesões ao patrimônio público ${ }^{52}$. A dualidade de jurisdições no sistema francês implica a existência de duas ordens jurisdicionais com competências distintas. Não há, em regra, um critério único para definir a competência do juiz administrativo em detrimento do juiz judiciário. Para eventuais conflitos positivos ou negativos entre essas duas ordens jurisdicionais, criou-se o Tribunal de Conflitos. Existem três níveis hierárquicos: o Conselho de Estado, as Cortes administrativas de apelação e os Tribunais administrativos.

Na França, por muito tempo, os parlamentos, corpos judiciários, se puseram em luta com o poder real e os intendentes (órgãos locais da Administração), embaraçando certas reformas administrativas que foram tentadas. A revolução de 1789 veio encontrar a opinião

\footnotetext{
50. FAGUNDES, Miguel Seabra. O Controle dos Atos Administrativos pelo Poder Judiciário. 7. ed. Rio de Janeiro: Forense, 2005. p. 148-149.

${ }^{51}$ ARAUJO, Edmir Netto. Curso de Direito Administrativo. 5. ed. São Paulo: Saraiva, 2010. p. 1280.

${ }^{52}$ Idem, Ibidem. p. 1278.
} 
pública prevenida, em consequência desses fatos, contra a ingerência dos corpos judiciários nos negócios administrativos. Sob essas influências, exclui, a legislação revolucionária, qualquer possibilidade de contato entre os Poderes Executivo e Judiciário, com a lei $\mathrm{n}^{\circ} 16$, de 24 de agosto de 1790, que estatuiu:

As funções judiciárias são distintas e ficarão sempre separadas das funções administrativas. Os juízes não poderão, sob pena de prevaricação, perturbar, por qualquer forma, as operações dos corpos administrativos ${ }^{53}$.

Com isso, a administração é juiz de seus atos e cabe a ela corrigir erros, conhecendo das reclamações suscitadas pelos administrados. As Leis 6, de 11 de setembro e 7, de 14 de outubro, ambas de 1.790, investem o Chefe do Estado e os Ministros e Corpos Departamentais nessa atribuição.

Esse modelo está de acordo com a concepção francesa de separação de poderes. Para essa concepção, deve-se vedar a penetração de um no âmbito peculiar de outro, implicando violação a esse princípio o julgamento pelo judiciário de controvérsias nascidas da atividade administrativa ${ }^{54}$. A jurisdição dúplice se estendeu para a Finlândia, a Grécia, a Turquia, a Iugoslávia, a Polônia, a Suíça e a Hungria ${ }^{55}$, e hoje é adotado por vários países.

Maurice Hauriou ${ }^{56}$ chama atenção para a conveniência de não confundir contencioso administrativo e jurisdição administrativa. O contencioso administrativo, segundo a sua percepção, compreende o conjunto de processos suscitados pela atividade da Administração Pública. Jurisdição administrativa é expressão que designa o conjunto de poderes de certos tribunais para o conhecimento das causas do contencioso administrativo. Tem um sentido semelhante ao das expressões jurisdição civil e jurisdição penal.

Nos países que adotam o chamado sistema de jurisdição única, quando se fala de jurisdição ordinária, compreende-se o conhecimento pelas autoridades judiciárias de quaisquer ações. Onde se adota o sistema oposto (duplicidade jurisdicional), aparece completamente organizada, ao lado da jurisdição comum ou ordinária, a administrativa, compreendendo o conhecimento das ações originárias de atos da administração Pública.

\footnotetext{
${ }^{53}$ FAGUNDES, Miguel Seabra. O Controle dos Atos Administrativos pelo Poder Judiciário. 7. ed. Rio de Janeiro: Forense, 2005. p. 150.

${ }^{54}$ Idem, Ibidem. p. 151.

${ }^{55}$ Idem, Ibidem. p. 152.

${ }^{56}$ HAURIOU, Maurice, Précis de Droit Administratif et de Droit Publique, 10. ed. Paris: Sirey, 1921, p. 869 apud FAGUNDES, Miguel Seabra. O Controle dos Atos Administrativos pelo Poder Judiciário. 7. ed. Rio de Janeiro: Forense, 2005. p. 141-nota de rodapé.
} 
Vale salientar que a jurisdição administrativa só está autorizada a apreciar o contencioso após a exaustão da via administrativa. O procedimento administrativo francês é formal e inquisitório. Outra particularidade é que a anulação de atos unilaterais administrativos poderá se dar em razão de forma, isto é, legalidade externa, ou de mérito, ou de legalidade interna.

\subsubsection{O sistema adotado no Brasil e suas controvérsias}

A Justiça brasileira adota o sistema de jurisdição una. Isso significa que somente o Poder Judiciário pode exercer a função jurisdicional. Nenhum contencioso administrativo que venha a ser instalado, nem os Tribunais de Contas, Tribunal Marítimo ou qualquer outro órgão não integrado na estrutura do Poder Judiciário pode substituí-lo ou exercer suas atribuições precípuas.

Ainda sobre o sistema jurídico brasileiro, destacamos que já se encontra pacificado o entendimento de que é possível que os atos administrativos discricionários possam ser controlados pelo Judiciário no que tange à sua legalidade e à sua legitimidade. Entretanto, a divergência se instaura, quando se suscita a extensão desse controle, sobretudo a partir da introdução de uma nova concepção do princípio da legalidade, que passa a abranger não só a conformidade com a lei, mas também com os princípios norteadores do ordenamento jurídico, caracterizando o que muitos doutrinadores vêm chamando de princípio da juridicidade, que restringe o campo do chamado mérito administrativo.

Aspecto importante a ser destacado e que se configura atualmente em tema amplamente debatido é aquele que trata do Controle Judicial das Políticas Públicas. Até que ponto o Poder Judiciário pode interferir nas Políticas Públicas?

Maria Paula Dallari Bucci ${ }^{57}$, em obra de sua lavra, esclarece que Políticas Públicas são "programas de ação governamental visando a coordenar os meios à disposição do Estado e as atividades privadas", para a realização de objetivos socialmente relevantes e politicamente determinados. O Poder Público estabelece quais interesses vai atender prioritariamente, já que ele não pode atender todos de uma só vez. A realidade demonstra que não há dotação orçamentária para atender a todos os interesses sociais. O Estado Social que brota da Constituição Federal vigente é muito pródigo em criar direitos do cidadão e deveres

\footnotetext{
${ }^{57}$ DALLARI BUCCI, Maria Paula. Direito Administrativo e Políticas Públicas. São Paulo: Saraiva, 2006. p. 241.
} 
do Estado, porém, como foi dito, não existem recursos suficientes para atender a todos os interesses sociais.

Conforme já expusemos em linhas anteriores, a teoria da tripartição dos Poderes propagada por Montesquieu mostra-se necessária para conservar a autonomia e a independência de cada um dos Poderes, afastando a concentração de todas as atividades em um único ente e prevenindo abusos. Entretanto esse critério tem sido posto em xeque, tendo em vista a atuação do Poder Judiciário nos dias atuais, que vem sistematicamente interferindo nas Políticas Públicas, na medida em que condena a Administração Pública, mediante ações individuais ou coletivas, ao fornecimento de remédios, tratamentos médicos, cirurgias etc.

A Administração Pública vem sendo ostensivamente compelida pelo Judiciário a arcar com despesas médicas e tratamentos de saúde mais complexos, nos casos em que o administrado, em ações individuais (propostas isoladamente), sem condições de arcar com os custos, busca a tutela jurisdicional, que via de regra, prolata uma sentença favorável.

Nos casos de ações coletivas, a defesa da Administração tem sido invocar o “Princípio da Reserva do Possível”. Nessas situações, diferentemente do que ocorre nas ações individuais, o Judiciário, à luz de tal princípio, reconhece a dificuldade e acaba por indeferir o pleito. A rigor, em homenagem ao critério da tripartição dos poderes, o Judiciário não poderia interferir e determinar o que é prioridade em termos de Políticas Públicas, pois essa matéria é de competência do Poder Legislativo. Porém, na prática, o Judiciário vem adentrando cada vez mais nessa seara, de forma sistemática, por duas razões:

a) Inércia ou omissão da Administração Pública, configurada pelo mal gasto do dinheiro público, a corrupção e o desvio de poder.

b) A forte atuação do Ministério Público na defesa dos direitos coletivos e difusos, sob o fundamento da garantia do "mínimo existencial dos direitos fundamentais".

A partir dessas ideias, nasceu um movimento denominado Judicialização das Políticas Públicas ou Politização do Judiciário, Ativismo Judicial, segundo o qual o Judiciário não se limita a dizer se a Administração Pública está agindo certo ou errado, mas cria regras a partir das suas decisões judiciais.

Nos casos das ações individuais, quando o Judiciário opta por prolatar uma sentença favorável, não se pode dizer que está interferindo em uma Política Pública diretamente, porque se trata de direito individual, e as políticas públicas têm um conceito mais genérico (são metas ou diretrizes). No entanto, a quantidade de processos dessa natureza é gigantesca, a ponto de afetar as políticas públicas. 
Esse fato tem provocado grande debate entre os juristas. Maria Sylvia Zanella Di Pietro $^{58}$ utiliza o exemplo em que o Ministério Público intentou ação para que o Município providenciasse saneamento básico para a população; outro exemplo dado por ela foi o caso em que o Ministério Público ajuizou ação em que pleiteava que um determinado Município fosse obrigado a providenciar a construção de um cemitério. Ela somente admite a interferência do Judiciário quando a opção da Administração Pública for antijurídica e considera inconcebível a ideia de que o Judiciário interfira na execução de políticas públicas, sendo descabida quando a opção da Administração Pública for razoável, aceitável e atender as metas constitucionais, asseverando que isso se configura na invasão da discricionariedade da Entidade Administrativa.

Elival da Silva Ramos, em tese apresentada na Universidade de São Paulo, tratando dos parâmetros dogmáticos do ativismo judicial em matéria constitucional, define que:

[por] Ativismo judicial, deve-se entender o exercício da função jurisdicional para além dos limites impostos pelo próprio ordenamento que incumbe, institucionalmente, ao Poder Judiciário fazer atuar, resolvendo litígios de feições subjetivas (conflitos de interesse) e controvérsias jurídicas de natureza objetiva (conflitos normativos).

O Debate está distante de ser pacificado, pois os juristas têm se debruçado sobre o tema, erguendo vários argumentos, de diferentes prismas, todos muito legítimos. Diante do atual contexto, perfilhamos o entendimento de Maria Sylvia Zanella Di Pietro, para quem há que haver limites de atuação do Judiciário sobre as Políticas Públicas, pois a Administração Pública tem o dever constitucional de promover tais políticas, entretanto a efetivação desse dever pode ser inviabilizada pela dificuldade criada pelo Judiciário, conforme destacamos em linhas anteriores.

58 Palestra proferida por MARIA SYLVIA ZANELLA DI PIETRO, disponível em: $\langle$ http://www.editoraatlas.com.br/tvWeb/webapp/video_detalhe.aspx?cod canal=1187\&cod_video=skq8Bj_7ax00. Acesso em: 28 set. 2012. 


\subsubsection{O controle político}

O controle político é matéria estudada mais detidamente no âmbito do Direito Constitucional, pois são inúmeras as hipóteses que traduzem esse controle, cujo objetivo é a preservação e o equilíbrio das instituições democráticas do país ${ }^{59}$. A Constituição Federal atual traz, no artigo 66, dois exemplos que ilustram as citadas hipóteses, no $\S 1^{\circ}$, conforme se verifica a seguir:

Art. 66 -

$\S 1^{\circ}$ - Se o Presidente da República considerar o projeto, no todo ou em parte, inconstitucional ou contrário ao interesse público, vetá-lo-á total ou parcialmente, no prazo de quinze dias úteis, contados da data do recebimento, e comunicará, dentro de quarenta e oito horas, ao Presidente do Senado Federal, os motivos do veto.

Na hipótese do $\S 1^{\circ}$, o Executivo controla o Legislativo por meio de vetos aos projetos originados nesse Poder. Por outra banda, o Legislativo controla o Executivo por meio da rejeição ao veto do Chefe deste Poder, conforme se depreende do referido dispositivo:

$\S 4^{\circ}$ - O veto será apreciado em sessão conjunta, dentro de trinta dias a contar de seu recebimento, só podendo ser rejeitado pelo voto da maioria absoluta dos Deputados e Senadores, em escrutínio secreto.

Conforme ensina Miguel Seabra Fagundes ${ }^{60}$, seguindo a evolução geral da teoria da separação dos órgãos e funções do Estado, observa-se, inicialmente, o surgimento do Poder Legislativo por meio do Parlamento. O soberano começa a sucumbir do seu absolutismo sob a pressão dos nobres e do povo. O Parlamento começa a exercer certo controle sobre os atos da Coroa. A sua atuação não se mostra jurídica sob qualquer aspecto, sendo puramente política.

O Judiciário fiscaliza a atuação dos outros dois Poderes (Executivo e Legislativo) pelo controle da legalidade e da constitucionalidade de seus atos. Em contraponto a isso, é o chefe do Poder Executivo que, exercendo controle político sobre o Judiciário, nomeia os integrantes dos mais altos Tribunais do país, conforme se verifica no art. 101, da atual Constituição, in verbis:

\footnotetext{
${ }^{59}$ CARVALHO FILHO, José dos Santos. Manual de Direito Administrativo. 25. ed. São Paulo: Atlas, 2012. p. 928.

${ }^{60}$ FAGUNDES, Miguel Seabra. O Controle dos Atos Administrativos pelo Poder Judiciário. 7. ed. Rio de Janeiro: Forense, 2005. p. 142.
} 
Art. 101. O Supremo Tribunal Federal compõe-se de onze Ministros, escolhidos dentre cidadãos com mais de trinta e cinco e menos de sessenta e cinco anos de idade, de notável saber jurídico e reputação ilibada.

Parágrafo único. Os Ministros do Supremo Tribunal Federal serão nomeados pelo Presidente da República, depois de aprovada a escolha pela maioria absoluta do Senado Federal.

José dos Santos Carvalho Filho ${ }^{61}$ faz referência ao controle político. Segundo seu entendimento, o Controle do Estado pode ser exercido de duas formas distintas, que merecem ser diferenciadas, o controle político e o controle administrativo.

De um lado temos o controle político, aquele que tem por base a necessidade de equilíbrio entre os Poderes estruturais da República - o Executivo, o Legislativo e o Judiciário. Nesse controle, cujo delineamento se encontra na Constituição, pontifica o sistema de freios e contrapesos, nele se estabelecendo normas que inibem o crescimento de qualquer um deles em detrimento de outro e que permitem a compensação de eventuais pontos de debilidade de um para não deixá-lo sucumbir à força de outro. São realmente freios e contrapesos dos Poderes políticos.

Essa modalidade de controle surgiu da já citada teoria da separação dos poderes, idealizada por Locke e Montesquieu, conforme já citamos anteriormente. Em O Espírito das Leis, Montesquieu sustentou que é fundamental que um Poder detenha o outro, e que todos devem atuar harmonicamente. O Poder soberano é uno e indivisível, entretanto suas funções devem ser diversificadas, e para cada uma delas é necessário criar um órgão próprio.

A Constituição Federal Brasileira atual, no artigo $2^{\circ}$, estabelece que “ - São Poderes da União, independentes e harmônicos entre si, o Legislativo, o Executivo e o Judiciário".

Ao lado do controle político, identificamos dois outros tipos de controle que têm despontado com maior destaque: o Controle Social e o Controle de Políticas Públicas.

Controle Social é o mecanismo de integração entre a Sociedade e a Administração Pública, com a finalidade de solucionar problemas e deficiências sociais com mais eficiência. A Carta Magna de 1988, ao propor a criação de espaços de participação popular, buscou garantir a construção de políticas sociais que atendam os interesses da população e o acompanhamento da gestão pública por parte dos administrados.

Além da legislação constitucional e infraconstitucional, aponta alguns instrumentos para a efetivação do controle social, conforme os exemplos a seguir:

a) Audiência Pública - evento em que se reúnem autoridades e interessados, em data e local previamente determinados e amplamente divulgados, para que sejam debatidos

\footnotetext{
${ }^{61}$ CARVAlHO FILHO, José dos Santos. Manual de Direito Administrativo. 25. ed.São Paulo: Atlas, 2012. p. 927.
} 
aspectos de determinado assunto em pauta, de interesse geral, ocasião em que todos têm a palavra.

A Lei 10.257, de 10 de julho de 2001 (Estatuto da Cidade), nos termos do parágrafo $4^{\circ}$, do artigo 40 , preleciona que os Municípios garantam a realização de audiências públicas com participação da população e de associações representativas, no processo de elaboração e fiscalização da implementação do plano diretor.

A Lei 8.666, de 21 de junho de 1993 (Lei de Licitações e Contratos), art. 39caput, prevê a obrigatoriedade de audiência pública antes da publicação de edital, sempre que o valor previsto em uma licitação ou em conjunto de licitações simultâneas e sucessivas ultrapasse 100 (cem) vezes o valor para obras e serviços de engenharia na modalidade de concorrência, podendo haver manifestação de todos os interessados.

b) Consulta Pública - É o meio pelo qual a Administração divulga um projeto, um plano, um programa que pretenda implementar. Destaque-se que sua principal finalidade é colher as opiniões dos administrados sobre temas de grande importância para a Comunidade. Esse sistema permite intensificar a articulação entre a representatividade e a sociedade, possibilitando a participação da Sociedade na formulação e definição de políticas públicas.

c) $\mathrm{O}$ artigo $74, \S 2^{\circ}$ da Constituição de 1988, atribui legitimidade a qualquer cidadão, partido político, associação ou sindicato para denunciar irregularidades ou ilegalidades perante o Tribunal de Contas.

\subsubsection{O controle financeiro e orçamentário}

O controle financeiro imposto à Administração Pública é exercido pelo Poder Legislativo, com o auxílio dos Tribunais de Contas e está adstrito à fiscalização contábil, financeira, orçamentária e patrimonial da Administração Pública direta e indireta, ou ainda a qualquer pessoa, física ou jurídica que utilize, arrecade, guarde, gerencie ou administre recursos públicos, nos termos do artigo 70 da Constituição Federal, in verbis:

Art. 70. A fiscalização contábil, financeira, orçamentária, operacional e patrimonial da União e das entidades da administração direta e indireta, quanto à legalidade, legitimidade, economicidade, aplicação das subvenções e renúncia de receitas, será exercida pelo Congresso Nacional, mediante controle externo, e pelo sistema de controle interno de cada Poder. 
O Senado tem competências para atuação em questões financeiras, orçamentárias e de crédito, conforme se verifica no artigo 52 da $\mathrm{CF} / 88$, reforçado pela Lei de responsabilidade fiscal.

\subsection{INSTRUMENTOS OU MEIOS DE CONTROLE}

A Constituição Federal atual determina que "todo o poder emana do povo", entretanto não é o povo quem administra o Estado diretamente, ele elege seus representantes que farão ecoar a sua voz no parlamento, editando as normas que os agentes públicos deverão seguir para alcançar o inafastável e pretendido interesse da coletividade.

A utilização de mecanismos na perseguição do interesse público, na fruição dos poderes que são atribuídos aos agentes públicos para alcançar esses objetivos, pode ultrapassar os limites, levando-os a cometer abusos ou ilegalidades. Por esse motivo, tornamse imprescindíveis a fiscalização (preventiva) e o controle dos atos da administração.

A Carta Magna vigente prevê ações específicas de controle da Administração Pública, às quais a doutrina se refere com a denominação de "remédios constitucionais". São assim chamados porque têm a natureza de garantias dos direitos fundamentais, encontrandose inseridos em Capítulo próprio da $\mathrm{CF} / 88$, cujo título tem o mesmo nome. A sua finalidade é provocar a intervenção das autoridades, via de regra, a Judiciária, para corrigir os atos da Administração que se mostram lesivos de direitos individuais ou coletivos.

Enquanto Maria Sylvia Zanella Di Pietro ${ }^{62}$ trata os referidos mecanismos de controle, sob a denominação de "meios de controle", Diógenes Gasparini ${ }^{63}$, qualifica-os como "instrumentos do controle jurisdicional”.

De acordo com José dos Santos Carvalho Filho ${ }^{64}$, os meios de controle judicial podem ser específicos e inespecíficos. Os meios específicos são aquelas ações que exigem a presença das pessoas administrativas ou de seus agentes no processo. São meios específicos a ação civil pública, a ação popular, o mandado de segurança, o mandado de injunção, o habeas corpus e o habeas data.

\footnotetext{
${ }^{62}$ DI PIETRO, Maria Sylvia Zanella. Direito Administrativo. 24. ed. São Paulo: Atlas, 2011. p. 772.

${ }^{63}$ GASPARINI, Diógenes. Direito Administrativo. 17. ed. São Paulo: Saraiva, 2012. p. 1063.

${ }^{64}$ CARVALHO FILHO, José dos Santos. Manual de Direito Administrativo. 25. ed. São Paulo: Atlas. 2012. p. 1009.
} 
Já os meios inespecíficos de controle judicial da Administração são aqueles representados pelas ações que não exigem necessariamente a presença do Estado em qualquer dos polos da relação processual, como por exemplo, as ações ordinárias, a ação penal (somente aquela que visa à condenação de agentes públicos por crimes contra particulares e contra a própria administração), os interditos possessórios, a nunciação por obra nova, a consignação em pagamento etc.

Todos os instrumentos são exercitados na instância civil, com exceção do habeas corpus que é utilizado na instância penal.

\subsubsection{Habeas Corpus}

O habeas corpus é medida judicial cujo objetivo é proteger o direito de locomoção dos indivíduos. Encontra-se esculpida no art. 5º inciso LXVIII, da atual Constituição Federal, determinando que: “conceder-se-á 'habeas-corpus' sempre que alguém sofrer ou se achar ameaçado de sofrer violência ou coação em sua liberdade de locomoção, por ilegalidade ou abuso de poder". E, ainda, no art. 647, do Código de Processo Penal, nos seguintes termos: "Dar-se-á habeas corpus sempre que alguém sofrer ou se achar na iminência de sofrer violência ou coação ilegal na sua liberdade de ir e vir, salvo nos casos de punição disciplinar" .

A origem etimológica da expressão "habeas corpus" provém do latim e significa "que tenhas teu corpo". A origem do referido instituto deita suas raízes no direito inglês, mais especificamente na Magna Carta de 1.215, imposta pelos nobres ao rei da Inglaterra, João sem Terra. O writ de habeas corpus, em sua gênese, aproximava-se do próprio conceito do devido processo legal (due process of law). Sua utilização só foi restrita ao direito de locomoção dos indivíduos em 1.679, por meio do Habeas Corpus Act.

Pontes de Miranda ${ }^{65}$, acerca do habeas corpus, ensinava que:

Histórica, tradicional e filosoficamente, o habeas corpus sempre foi mandado-remédio (remedial mandatory writ), da classe dos extraordinary remedies; e, como a proteção possessória, que representa complemento necessário da proteção da propriedade, facilitação da prova em favor do proprietário, embora isso redunde, por vezes, em benefícios a nãoproprietários, o habeas corpus foi criado para a proteção da liberdade física.

\footnotetext{
${ }^{65}$ MIRANDA, Pontes de. História e Prática do Habeas-Corpus. 7. ed. Rio de Janeiro: Borsoi, 1972. p. 3.
} 
No ordenamento jurídico brasileiro, surgiu pela primeira vez no Código de Processo Criminal do Império, nos termos do art. 340, de 1.832 afirmando que: "Todo cidadão que entender que ele, ou outrem, sofre uma prisão ilegal ou constrangimento ilegal em sua liberdade tem direito de pedir uma ordem de habeas corpus em seu favor."

O Instituto alcançou status constitucional na Carta Magna de 1.891, nos termos do art. $72, \S 22$, em que se estabelecia que: "Dar-se-á habeas corpus sempre que o indivíduo sofrer ou se achar em iminente perigo de sofrer violência ou coação, por ilegalidade ou abuso de poder".

Atualmente, há duas modalidades de habeas corpus, o preventivo e o repressivo. O habeas corpus preventivo é aquele que é impetrado mediante a ameaça de constrangimento à liberdade, ou seja, antes que a prisão seja efetivada. Já o habeas corpus repressivo é a medida cabível quando o ato concreto de constrangimento já se aperfeiçoou, isto é, a prisão já foi consumada, cerceando o direito de ir, vir e ficar.

Qualquer indivíduo, brasileiro ou estrangeiro, pode impetrar habeas corpus em benefício próprio ou alheio. Para que seja exercitado indistintamente e para que não haja restrição na sua utilização, o art. $5^{\circ}$, inciso LXXVII da CF/88 prescreve a gratuidade tanto do habeas corpus, quanto do habeas data, na seguinte forma: "são gratuitas as ações de habeascorpus e habeas-data, e, na forma da lei, os atos necessários ao exercício da cidadania”.

Muito embora o habeas corpus tenha como característica a celeridade, o requerimento de medida liminar é perfeitamente admissível, desde que estejam presentes os requisitos necessários para a concessão da referida ordem, quais sejam, o fumus boni iuris e o periculum in mora.

A jurisprudência mais autorizada reconhece o cabimento de medida liminar em sede de habeas corpus conforme já decidiu o eminente Ministro Celso de Mello:

A medida liminar, no processo penal de habeas corpus, tem o caráter de providência cautelar. Desempenha importante função instrumental, pois destina-se a garantir - pela preservação cautelar da liberdade de locomoção física do indivíduo - a eficácia da decisão a ser ulteriormente proferida quando do julgamento definitivo do writ constitucional (RTJ 147/962). HC 79748 RJ, origem: Rio de Janeiro.

Julgamento 09/11/1999, Publicação DJ 17/11/1999. Partes Paulo Martins da Silva , Carlos Antonio de Oliveira Lima e outros, Relator(a): CELSO DE MELLO.

Para impetração de habeas corpus, é indispensável identificar a presença dos seguintes pressupostos: a) ilegalidade ou abuso de poder, b) violência, coação e ameaça à liberdade de locomoção. 


\subsubsection{Habeas Data}

Habeas data é a ferramenta jurídica empregada na proteção do direito líquido e certo de conhecimento de informações e registros relativos ao impetrante.

Configura-se em ação judicial, uma vez que estão presentes os elementos fundamentais da ação - partes, causa de pedir e pedido. Observe-se que é destinada à tutela dos direitos do cidadão à frente dos bancos de dados públicos ou que exerçam tais funções, a fim de permitir o fornecimento e o acesso das informações registradas, bem como sua retificação, em caso de não corresponder à verdade quando não se prefira fazê-lo por processo sigiloso, judicial ou administrativo.

A Constituição Federal de 1.988 recepcionou pioneiramente o habeas data, nos termos do art. $5^{\circ}$, inciso LXXII, cujo rito processual está regulado pela Lei Federal $\mathrm{n}^{\circ}$ 9.507, de 12 de novembro de 1.997, que além de disciplinar o procedimento da ação, também acrescentou mais uma hipótese de cabimento da medida, além daquelas já previstas na CF/88.

\subsubsection{Mandado de injunção}

O embasamento legal da ação mandamental está albergado no art. $5^{\circ}$, inciso LXXI da atual CF/88, em que se vislumbra: "Conceder-se-á mandado de injunção sempre que a falta de norma regulamentadora torne inviável o exercício dos direitos e liberdades constitucionais e das prerrogativas inerentes à nacionalidade, à soberania e à cidadania" .

Não há, ainda, no ordenamento jurídico pátrio, lei ordinária que regulamente especificamente o mandado de injunção; todos os aspectos da medida devem ser analisados somente à luz do texto constitucional. Sendo meio específico de controle da Administração, seu procedimento é contencioso, uma vez que o processo contém controvérsia litigiosa, e especial, considerando que obedece a um rito próprio, que a jurisprudência entendeu fosse o do mandado de segurança e a lei acabou por enveredar-se no mesmo sentido ${ }^{66}$.

Note-se que a Lei $\mathrm{n}^{\mathrm{o}}$ 8.038, de 28 de maio de 1.990, que institui normas procedimentais para os processos que especifica perante o Superior Tribunal de Justiça e o

${ }^{66}$ CARVALHO FILHO, José dos Santos. Manual de Direito Administrativo. 25 ed. São Paulo: Atlas, 2012. p. 1043. 
Supremo Tribunal Federal, previu expressamente que o mandado de injunção seguirá o rito do mandado de segurança enquanto não sobrevier a legislação específica regulando o tema, nos seguintes termos:

Art. 24 -

Parágrafo único - No mandado de injunção e no habeas data, serão observadas, no que couber, as normas do mandado de segurança, enquanto não editada legislação específica.

\subsubsection{Mandado de se gurança}

Mandado de Segurança é uma ação constitucional destinada a proteger direito líquido e certo, não amparável por habeas corpus ou habeas data, em caso de ilegalidade ou abuso de poder praticado por autoridade pública ou agente no exercício e atribuições do Poder Público ${ }^{67}$.

Este remédio jurídico encontra-se esculpido no artigo $5^{\circ}$, inciso LXIX e LXX, da Lei Maior atual, nas modalidades de individual e coletivo, regulado pela Lei 12.016, de 07 de agosto de 2.009 .

Celso Antonio Bandeira de Mello ${ }^{68}$ observa que:

O mandado de segurança individual visa a assegurar o direito pertinente individualmente ao impetrante ou impetrantes, ao passo que o mandado de segurança coletivo é via aberta aos partidos políticos com representação no Congresso Nacional, às organizações sindicais, entidades de classe ou associações legalmente constituídas e em funcionamento há pelo menos um ano, em defesa daqueles interesses de seus membros ou associados que concernem ao fator que os agrega na entidade, dadas as finalidades que the correspondem e consubstanciam seu objeto social.

Muito embora o Mandado de Segurança seja mais utilizado contra atos comissivos, isto é, aqueles efetivamente praticados pelos agentes públicos, não há controvérsias quanto ao cabimento também contra atos omissivos (ou omissões

\footnotetext{
${ }^{67}$ JUSTEN FILHO, Marçal. Curso de Direito Administrativo. São Paulo: Saraiva, 2005. p. 756.

${ }^{68}$ BANDEIRA DE MELlO, Celso Antonio. Curso de Direito Administrativo. 28. ed. São Paulo: Malheiros. 2011. p. 962.
} 
administrativas) ou pessoas com funções delegadas, uma vez que tais omissões equivalem a atos de autoridades ${ }^{69}$.

A doutrina já se posicionou nessa mesma linha, e esse posicionamento foi confirmado pela jurisprudência no Supremo Tribunal Federal, na seguinte medida:

MANDADO DE SEGURANÇA. PAGAMENTO DE VENCIMENTOS DECADÊNCIA. 1. Não ocorre a decadência se a impetração é feita contra atos omissivos de execução autônoma e sucessiva, como o pagamento de vencimentos mensais (RE 70.319, rel. Min. Aliomar Baleeiro, RE 79.888, rel. Min. Moreira Alves e RE 95.238, rel. Min. Neri da Silveira). 2. Recurso provido. RMS 24.214, Rel. Min. Ellen Gracie em 14.6.20.5, Recorrente Paulo Roberto Brasileiro do Nascimento, Recorrida UNIÃO.

\subsubsection{Ação popular}

A ação popular encontra amparo legal no dispositivo constitucional estampado no artigo $5^{\circ}$, inciso LXXIII, da Lei Maior, caracterizando-se como o instrumento colocado à disposição de qualquer cidadão a fim de anular atos lesivos ao patrimônio público ou de entidade de que o Estado participe, ou, ainda à moralidade administrativa, ao meio ambiente, bem como ao ambiente histórico e cultural.

A Lei 4.717, de 29 de junho de 1.965, regula a Ação Popular. Na opinião de Celso Antonio Bandeira de Mello ${ }^{70}$, é, talvez, a única medida judicial que, efetivamente, amedronta os administradores, uma vez que, conforme o art. 11 da referida lei, na hipótese de a ação ser julgada procedente, determinando a decretação da invalidade do ato impugnado, a decisão “condenará ao pagamento de perdas e danos os responsáveis pela sua prática e os beneficiários dele".

Importante destacar que a Ação Popular não foi uma inovação trazida pela Constituição de 1.988, uma vez que a Carta Constitucional de 1.946, em Capítulo destinado aos Direitos e às Garantias individuais, nos termos do art. 141, § 38, já tratava do tema, muito embora de forma menos abrangente.

\footnotetext{
${ }^{69}$ CARVALHO FILHO, José dos Santos. Manual de Direito Administrativo. 25. ed. São Paulo: Atlas, 2012. p. 1032.

${ }^{70}$ BANDEIRA DE MELLO, Celso Antonio. Curso de Direito Administrativo. 28.ed. São Paulo: Malheiros. 2011. p. 964.
} 


\subsubsection{Ação civil pública}

A Ação Civil Pública é o remédio jurídico de que o Ministério Público ou outras entidades legitimadas se utilizam para a defesa de interesses coletivos, difusos e individuais homogêneos. Não se destina à defesa de interesse ou direito individual.

A Constituição Federal de 1.988, no artigo 129, § 1º, aponta o Ministério Público como parte legítima para propor a Ação Civil Pública, entretanto não lhe dá exclusividade, pois essa prerrogativa é concorrente com outros legitimados, conforme se depreende do artigo $5^{\circ}$, da Lei 7.347, de 24 de julho de 1985, que disciplina a ação civil pública de responsabilidade por danos causados ao meio-ambiente, ao consumidor, a bens e direitos de valor artístico, estético, histórico, turístico, in verbis:

Art. $5^{0}$ Têm legitimidade para propor a ação principal e a ação cautelar:

I - o Ministério Público;

II - a Defensoria Pública;

III - a União, os Estados, o Distrito Federal e os Municípios;

IV - a autarquia, empresa pública, fundação ou sociedade de economia mista;

$\mathrm{V}$ - a associação que, concomitantemente:

a) esteja constituída há pelo menos 1 (um) ano nos termos da lei civil, b) inclua, entre suas finalidades institucionais, a proteção ao meio ambiente, ao consumidor, à ordem econômica, à livre concorrência ou ao patrimônio artístico, estético, histórico, turístico e paisagístico.

§ 5. Admitir-se-á o litisconsórcio facultativo entre os Ministérios Públicos da União, do Distrito Federal e dos Estados na defesa dos interesses e direitos de que cuida esta lei.

Poderá figurar no polo passivo da Ação Civil Pública qualquer pessoas física ou jurídica que seja agente causador de dano a quaisquer interesses coletivos, difusos ou individuais homogêneos.

A Defensoria Pública foi incluída no rol de legitimados para o manejo da ação civil pública, por força da Lei $11.448 / 07$, que alterou o artigo $5^{\circ}$ da Lei $7.347 / 85$. A lei Complementar $\mathrm{n}^{\circ}$ 80, de 12 de janeiro de 1994, art. $4^{\circ}$, alterada pela Lei Complementar 132 de 07 de outubro de 2009, determina que:

Art. $4^{\circ}$ São funções institucionais da Defensoria Pública, dentre outras:

VII - promover ação civil pública e todas as espécies de ações capazes de propiciar a adequada tutela dos direitos difusos, coletivos ou individuais homogêneos quando o resultado da demanda puder beneficiar grupo de pessoas hipossuficientes [...] 
No caso das associações, o pressuposto de admissibilidade configurado na préconstituição poderá ser dispensado pelo juiz, quando for manifesto interesse social, evidenciado pela natureza e dimensão da lesão, ou pela relevância do bem jurídico protegido.

Dentre todos os legitimados, o Ministério Público é o mais atuante, talvez porque essa legitimidade decorra da própria Constituição Federal, nos termos do artigo 129, inciso III:

Art. 129. São funções institucionais do Ministério Público:

I - promover, privativamente, a ação penal pública, na forma da lei;

II - zelar pelo efetivo respeito dos Poderes Públicos e dos serviços de relevância pública aos direitos assegurados nesta Constituição, promovendo as medidas necessárias a sua garantia;

III - promover o inquérito civil e a ação civil pública, para a proteção do patrimônio público e social, do meio ambiente e de outros interesses difusos e coletivos.

Na hipótese de não figurar como parte, o Ministério Público deverá intervir, obrigatoriamente, como fiscal da lei, podendo assumir a titularidade ativa quando houver desistência infundada ou abandono por parte do autor da ação.

Para o melhor desempenho dessa relevante função, a Constituição Federal de 1.988, colocou à disposição do Ministério Público, o Inquérito Civil, que se caracteriza por procedimento de natureza investigatória e de caráter administrativo, presidido pelo Ministério Público, no qual poderão ser requisitados, de quaisquer órgãos públicos, certidões, informações, exames ou perícias. No Inquérito Civil, poderão ser expedidas notificações, ouvidas testemunhas, ou solicitadas quaisquer diligências.

Inserida no Ordenamento Jurídico pela Lei 7.347/85, a Ação Civil Pública tem por finalidade evitar ou prevenir danos ao meio ambiente, ao consumidor, ao patrimônio público, aos bens e direitos de valor artístico, histórico, cultural e turístico, podendo ser objeto de condenação pecuniária ou cumprimento de obrigação de fazer ou de não fazer.

Tanto a Ação Coletiva quanto a Ação Civil Pública são efetivos instrumentos de Justiça, pois por meio delas o cidadão encontra a compensação de seus prejuízos, sem necessidade de ajuizar individualmente o litígio, hipótese em que teria que contratar advogado e arcar com o ônus de um processo judicial, na maioria dos casos, obtendo sentenças contraditórias. Já no caso da ação coletiva e da ação civil pública, se procedente, beneficia todo o grupo lesado, representando uma enorme economia processual. 


\subsubsection{Ação direta de inconstitucionalidade}

A Ação Direta de Inconstitucionalidade está regulada pela Lei ${ }^{\circ}$ 9.868, de 10 de novembro de 1.999, cujos critérios de competência e legitimação encontram-se esculpidos nos artigos 102, inciso I, e 103, da Constituição Federal de 1.988. Será interposta para que seja apreciada em hipótese de inconstitucionalidade de lei ou ato normativo, objetivando seu banimento do ordenamento jurídico.

A ADIn poderá ser por omissão, nos termos do $\S 2^{\circ}$, do artigo 103, hipótese em que o objetivo da ação será o reconhecimento judicial da inércia do Poder competente em expedir providência normativa, afrontando a norma constitucional

\subsection{COISA JULGADA ADMINISTRATIVA}

A coisa julgada é tema estudado mais detidamente na Teoria Geral do Processo, cujo objeto é a imutabilidade de uma decisão, ou seja, que a decisão não pode mais ser alterada. Saliente-se que esta figura é própria da função jurisdicional do Estado, função essa que tem o objetivo de autorizar que o juiz aplique a lei no caso concreto ${ }^{71}$.

No Direito Administrativo, quando a doutrina trata da coisa julgada administrativa, está se apropriando deste instituto em decorrência das semelhanças que apresenta tanto na seara judicial quanto na esfera administrativa, entretanto é necessário compreender que tais semelhanças não equiparam a coisa julgada administrativa à coisa julgada judicial.

A coisa julgada administrativa revela-se na imutabilidade da decisão administrativa dentro da Administração Pública. Trata-se do não cabimento de recurso na via administrativa. Todavia, não impede que haja análise pelo Poder Judiciário, por força do artigo $5^{\circ}$, inciso XXXV, que determina que "nenhuma lesão ou ameaça ao direito será excluída da apreciação do Poder Judiciáro", motivo pelo qual não é considerada uma verdadeira coisa julgada, haja vista não gerar a perenidade da decisão, atributo que somente está presente nas decisões judiciais.

\footnotetext{
${ }^{71}$ CARVALHO FILHO, José dos Santos. Manual de Direito Administrativo. 25. ed. São Paulo: Atlas. 2012. p. 954.
} 
O fato de a "coisa julgada" administrativa não impedir a análise da matéria pelo Poder Judiciário decorre do mecanismo de controle adotado pelo ordenamento jurídico brasileiro, segundo o qual todos os litígios devem ser resolvidos preferencialmente pela justiça comum. É o chamado sistema de jurisdição única, conforme já mencionamos em tópico anterior.

\subsection{PRESCRIÇÃO E DECADÊNCIA}

A prescrição é a perda da oportunidade de formular uma pretensão na via judicial, em decorrência da inércia do titular do direito material. Não é o direito material que se extingue, mas sim a pretensão à tutela, a ser requerida por meio de ação judicial. Já a decadência se diferencia da prescrição na medida em que decreta a extinção do próprio direito material. A prescrição pode ser interrompida, enquanto na decadência não há paralização do decurso de prazo, a menos que a lei expressamente admita.

Também pode ser considerada como meio de controle interno da Administração Pública a decretação ou o reconhecimento da prescrição ou da decadência pela autoridade competente, pois o decurso do tempo pode afetar as relações jurídicas, seja para aquisição, seja para perda de direitos.

A doutrina entende que prescrição administrativa é a perda do prazo para recurso administrativo pelo interessado, ou o escoamento do prazo para que a Administração reexamine e/ou modifique seus próprios atos ou, ainda, na esfera disciplinar, a perda do prazo para que a Administração apure responsabilidades e aplique penalidades administrativas.

\section{Conclusão}

Controle, resumidamente, pode ser conceituado como o conjunto de instrumentos jurídicos cuja finalidade é a fiscalização (controle prévio ou a priori) e a correção (controle posterior ou a posteriori) das atividades da Administração Pública. 
O Direito Administrativo coloca à disposição da Sociedade Civil várias formas de controle da atividade administrativa e política (voto), entretanto a omissão individual em participar do processo político e democrático, acarreta a ampliação do arbítrio governamental.

O Controle interno é aquele exercido pela própria Administração na relação de subordinação hierárquica, sobre seus próprios atos e agentes, ou por sistema de auditoria que acompanha seu exercício.

O Controle externo da Administração Pública é feito pelo Parlamento, por intermédio do Tribunal de Contas e pelo Judiciário.

A Emenda Constitucional $n^{\circ} 45$, que trata da reforma do Poder Judiciário, criou o Conselho Nacional de Justiça - CNJ, que tem, entre suas atribuições, a elaboração de políticas estratégicas para o Judiciário, fiscalização da gestão administrativa e financeira dos tribunais e, em caráter suplementar, trata também de questões disciplinares, controlando a atuação dos juízes. O CNJ é integrado por quinze membros que exercem mandato de dois anos, permitida a recondução.

A mencionada Emenda também criou o Conselho Nacional do Ministério PúblicoCNMP, cujas atribuições são zelar pela autonomia funcional e administrativa do Ministério Público, receber e conhecer as reclamações contra membros ou órgãos do MP, entre outras. O CNMP é composto por catorze membros, dos quais seis de fora do Ministério Público, com mandato de dois anos, admitindo-se recondução. 


\section{CONCLUSÕES FINAIS}

O esforço empreendido ao longo desta dissertação foi dirigido para a análise dos diversos aspectos que o tema central - Responsabilidade do Estado por omissão - apresenta. Muito embora tenhamos procurado traçar os conceitos aqui envolvidos da maneira mais clara possível, muitos deles ainda carecem de uma análise mais detida e, por certo, dúvidas e questionamentos hão de emergir.

Alguns aspectos periféricos foram suscitados e, embora possa parecer que não têm ligação direta com o tema central, contribuem para nossa sugestão da observação do instituto da responsabilidade por omissão sob um novo ângulo, como, por exemplo, a incorporação e a positivação dos princípios da prevenção e da precaução no rol de princípios informativos da atividade administrativa. Mesmo não sendo uma inovação, poucos autores ousaram advogar em favor de sua aplicabilidade.

No primeiro capítulo, buscou-se delinear, em apertada síntese, a trajetória histórica da responsabilidade do Estado ao longo dos tempos. Verificamos, nessa parte da dissertação, que muito embora alguns respeitáveis doutrinadores utilizem a terminologia responsabilidade civil do Estado, parece mais coerente a utilização da denominação Responsabilidade Extracontratual do Estado apenas, pois o vocábulo "civil” remete-nos à noção de culpa, e, ainda, tem-se que ao Estado não é possível ser atribuída outra forma de responsabilização, ao menos nos mesmos parâmetros em que esta é atribuída às pessoas naturais.

Saliente-se que, no princípio, em épocas de governos absolutistas e despóticos, o entendimento reinante pautava-se na irresponsabilidade do Estado, pois a figura do monarca era considerada a personificação do Estado e sua soberania advinha de um poder divino. Nessa linha de raciocínio, era inadmissível a ideia de que o monarca cometia erros que pudessem resultar em danos passíveis de ser indenizáveis. Ressalve-se, entretanto, que havia apenas a remota possibilidade de responsabilizar danos causados pelo agente público atuante.

No segundo estágio evolutivo da responsabilidade estatal, vislumbrou-se o Estado como responsável pelos atos culposos que seus prepostos praticassem em detrimento dos administrados. Restou superada a teoria da irresponsabilidade, admitindo-se, a partir de então, a responsabilidade do Estado por culpa, mas era necessário distinguir os atos de gestão e de império. Quando se tratava de danos ocasionados pela prática de atos de gestão, era 
plenamente possível suscitar a responsabilização estatal, mas quando os danos eram resultantes da prática de atos de império, o Estado não poderia ser responsabilizado. A dificuldade em se identificar a natureza do ato impossibilitava, pois, a reparação e, desse modo, abandonou-se a distinção entre a natureza dos atos para fins de responsabilização estatal. Em seguida, passou-se a adotar a teoria da culpa administrativa ou culpa anônima, ou ainda a responsabilização pela falta do serviço. Então, mesmo que a responsabilização continuasse a se basear na ideia de culpa, bastava a mera prova de que o serviço não funcionou, funcionou mal ou funcionou tardiamente, para a comprovação da culpa estatal, sendo dispensável, repita-se, a identificação individual do funcionário que praticou a conduta lesiva.

No terceiro e atual estágio evolutivo da responsabilidade do Estado, prevalece a teoria objetiva, desvinculada de qualquer ideia de culpa (dolo ou culpa em sentido estrito), admitida pelos diversos ordenamentos jurídicos. No Brasil, a teoria objetiva está positivada desde a Constituição Federal de 1.946. O ordenamento jurídico pátrio agasalhou a teoria objetiva pautada no risco administrativo, hipótese em que o Estado somente fica desobrigado de responsabilização quando houver incidência de uma das causas excludentes.

A Responsabilidade Civil, seja do Estado, ou de particulares, é inerente à lógica do Estado de Direito, a qual submete todos ao império da lei. Além da legalidade, impõem-se também, os princípios de igualdade e justiça.

Não há dúvidas quanto à obrigação do Estado de indenizar os prejuízos causados a terceiros, oriundos de suas atividades estatais. São, portanto, três elementos configuradores da responsabilidade do Estado: o fato administrativo, o dano (moral ou patrimonial) e, por fim, a existência do nexo de causalidade entre o fato administrativo e o resultado danoso.

A responsabilidade extracontratual do Estado independe da ilicitude ou não do comportamento do agente em sua conduta funcional, desde que não haja causa de exclusão da responsabilidade estatal.

No segundo capítulo, buscou-se primeiramente trazer à lume, em linhas gerais, o papel do Estado, para, em seguida empreender-se a tentativa de focalizar a responsabilidade do Estado pela omissão, e as consequências que a conduta omissiva pode acarretar, suscitando o problema do significado do vocábulo faute, importado da doutrina francesa, mas que, pela tradução equivocada, provoca, ainda, confusão na conceituação do instituto entre os doutrinadores brasileiros, sendo causa de divergência tanto doutrinária quanto jurisprudencial. 
Para verificar se há omissão danosa - ou, como prefere Juarez de Freitas, omissão desproporcional, - aquela passível de reparação, deve-se verificar se a omissão estatal é socialmente benéfica, se é omissão que negligencia os mecanismos para obtenção eficaz e razoável dos fins colimados pela Administração, ou ainda, se a omissão é necessária ou se refere à abstenção da prática do ato que impõe sacrifícios iníquos e inaceitáveis na distribuição dos encargos.

Também consideramos importante, neste estudo, distinguir a responsabilidade do Agente Público daquela imputada ao Estado, pois aquele, sendo a pessoa natural que presta serviços a este e às pessoas jurídicas da Administração indireta, pode, no exercício de suas funções ou em razão desse exercício, praticar atos ilícitos, cuja repercussão atinja as esferas civil, penal e administrativa.

Nesse contexto, destacou-se a responsabilidade inominada do Estado decorrente de variações climáticas, movimentos sociais e multitudinários.

A fim de proporcionar uma visão solar da questão que envolve a Responsabilidade Estatal, pontuamos alguns aspectos relativos à reparação do dano, e levantamos a questão relacionada à denunciação da lide, sem deixar de fazer menção à obrigação do Estado em exercitar o direito de regresso contra o agente causador do dano, e por fim, fazendo referência ao instituto da prescrição.

Por todos os argumentos esposados e o contexto geral, nosso posicionamento é no sentido de que é aplicável a Teoria Objetiva, na modalidade de Risco Administrativo, nos casos de comportamentos omissivos que causarem danos a terceiros, considerando a necessidade de proteger a vítima ante a dificuldade em demonstrar a culpa ou o dolo do agente público, ou que o serviço não funcionou, funcionou mal, ou funcionou tardiamente. Ademais, a doutrina que sustenta a teoria subjetiva mostra-se muito frágil. Além disso, o artigo 43 do Código Civil de 2.002, corroborando a norma constitucional, estabelece que há que se falar em culpa apenas na hipótese de ação regressiva movida pelo Estado face ao agente causador do dano.

Nos dizeres de Juarez de Freitas ${ }^{1}$, “O tempo da tolerância para as omissões ilícitas e desproporcionais precisa chegar ao fim".

Como se percebe, em matéria de Responsabilidade do Estado, há um longo caminho a ser trilhado. A expansão da atividade estatal no Estado contemporâneo tem fomentado a discussão e a renovação do debate sobre a responsabilidade do Estado por

\footnotetext{
${ }^{1}$ FREITAS, Juarez. Sustentabilidade - Direito ao Futuro. 2. ed. Belo Horizonte: Fórum, 2012. p. 281.
} 
condutas omissivas. A responsabilidade do Estado, nesse sentido, é mero resultado da submissão do Poder Público ao Direito.

Outra reflexão importante e que vale a pena ser observada é o fato de a responsabilidade do Estado fundamentar-se em dois princípios: o princípio da legalidade e o princípio da igualdade, como forma de garantir uma repartição equânime dos ônus e encargos de atos ou omissões danosas, impedindo que apenas alguns suportem prejuízos decorrentes de atividades do interesse da coletividade.

Nessa linha de raciocínio, a responsabilidade do Estado por omissão merece ser reformulada como dever - das pessoas jurídicas de direito público e privado prestadoras de serviços públicos e de direito privado prestadoras de serviços públicos lato sensu - de prevenir danos incidentes sobre o contexto atual e futuro e, se for o caso, indenizar e recompor o patrimônio, independentemente de conjecturas acerca de culpa ou dolo, seja por ação ou omissão.

A Responsabilidade do Estado corresponde à obrigação que lhe é imposta de reparar os danos causados por seus agentes, no exercício de suas funções, ou os danos causados em decorrência do exercício da atividade estatal, mesmo que não se possa identificar ou individualizar quem foi, efetivamente, o causador da lesão. A Constituição Federal adotou a teoria da responsabilidade objetiva e subjetiva dos agentes públicos nos termos do artigo 37 , $\S 6^{\circ}, \mathrm{da} \mathrm{CF} / 88$.

Celso Antônio Bandeira de Mello² aponta três tipos de situações ensejadoras de responsabilização estatal: (a) a primeira se consubstancia na ação, circunstância que exige a aplicação da teoria objetiva; (b) a segunda situação baseia-se na omissão, que segundo a doutrina majoritária é suscetível à teoria subjetiva; e por derradeiro, (c) as situações produzidas pelo Estado diretamente propiciatórias de dano, que se equiparam à conduta comissiva.

Distingue-se o dever de ressarcir e o dever de indenizar. O primeiro decorre de ato ilícito; o segundo decorre mesmo de ato lícito que cause prejuízo a outrem.

No que tange à responsabilidade por omissão, ressalte-se que a expressão falta de serviço provém de tradução defeituosa da palavra francesa faute, uma vez que, na França, o real significado desse vocábulo é "culpa".

\footnotetext{
${ }^{2}$ BANDEIRA DE MELLO, Celso Antônio. Curso de Direito Administrativo. 28. ed. São Paulo:Malheiros, 2010. p. 1018.
} 
A responsabilidade extracontratual baseia-se, de acordo com a teoria clássica, em três elementos essenciais: o dano, a culpa do ofensor e a relação de causalidade entre o fato culposo e o dano.

O Estado é responsável por danos causados ao administrado em decorrência das atividades legislativas e judiciárias, uma vez que ambas se configuram em função do Estado: não são serviços administrativos, mas serviços públicos.

No terceiro capítulo, as reflexões expostas têm a finalidade de reconsiderar as bases do direito administrativo, pois só é concebível um direito que privilegie a visão antropocêntrica, mesmo porque o ser humano é a razão de o Estado existir. O Estado assumiu o importante papel de concretizar os direitos fundamentais, entretanto tem obrigação de lançar mão de todos os recursos a fim de garantir sua efetivação.

Não se trata de um Estado intervencionista, mas um Estado cuidador, atento e diligente; nesse espírito, a recepção dos princípios da precaução e da prevenção no estudo do direito administrativo, mais especificamente na análise da Responsabilidade Estatal, se apresenta como uma nova perspectiva, um novo rumo no sentido de aperfeiçoar a atuação do Estado no exercício de suas atividades.

É certo que, aos operadores do direito, caberá a tarefa de delinear novos limites, valores e princípios, visando implementar, na Ciência Jurídica, a interdisciplinaridade inerente a essa nova realidade tecnológica e cultural que vem transformando todo o cenário mundial.

O princípio da precaução pode ser invocado sempre que for necessária uma intervenção urgente face ao possível risco para a saúde humana, animal ou vegetal, ou quando necessário para a proteção do ambiente, caso os dados científicos não permitam uma análise completa do risco, ou seja, quando não for possível medir o risco com certeza suficiente.

Tal princípio somente poderá ser invocado na hipótese de risco potencial, não podendo nunca justificar a tomada de decisão arbitrária, e sua aplicação fica condicionada à verificação de três condições: (a) identificação dos efeitos potencialmente negativos; (b) avaliação dos dados científicos disponíveis; (c) extensão das incertezas científicas.

O princípio da precaução mostra-se como uma alternativa inovadora para preservar a humanidade de ameaças reais ou mesmo do sentimento generalizado de medo em relação à defesa da saúde pública, da qualidade dos alimentos e do equilíbrio do meio ambiente.

No mundo em que vivemos, fatos e atos modificam a natureza das coisas e a vida das pessoas, para melhor ou para pior, conforme disposição das normas e regras ou com a infração de tais normas ou regras. Em certa medida, os acontecimentos têm vontade própria, 
ocorrem independentemente do querer humano e proporcionam mutações grandes ou pequenas nas coisas e nos indivíduos. Nesses casos, via de regra, nenhum indivíduo é responsável pelo evento, nenhuma pessoa natural ou jurídica ou entidade criada pelo homem é chamada a responder pelas mudanças operadas, como lhes tendo dado causa.

No entanto, mesmo no terreno dos fatos, pode incidir a responsabilização, como, por exemplo, no caso em que a previsibilidade humana poderia ter ceifado os efeitos danosos do fato do mundo. Neste caso, excepcionalmente, o indivíduo adere ao fato para efeitos de responsabilidade, porque embora não seja causa direta do fato é causa direta do dano, pois podendo impedi-lo não o fez ${ }^{3}$.

E fechamos o nosso raciocínio, abraçando as considerações de Juarez de Freitas ${ }^{4}$, mas indo mais longe. Para ele, o princípio da prevenção, no Direito Administrativo e no Direito Ambiental, determina, sem mora ou sofisma acomodatício, o cumprimento, diligente, eficiente e eficaz, da obrigação estatal de impedir o nexo causal de danos perfeitamente previsíveis. Nós complementamos esse raciocínio, concluindo que, aliado ao princípio da prevenção, o da precaução também encontra destaque, uma vez que não há pretexto para a passividade complacente, submissa e servil do Ente Estatal.

A proposta de assimilar os princípios da prevenção e da precaução, incorporandoos ao rol de princípios informativos do Direito Administrativo, provém do fato de acreditarmos que a prudência é virtude do homem sábio.

No quarto e último capítulo, apresentamos o Controle, que, resumidamente, pode ser conceituado como o conjunto de instrumentos jurídicos cuja finalidade é a fiscalização (controle prévio ou a priori) e a correção (controle posterior ou a posteriori) das atividades da Administração Pública.

O Direito Administrativo coloca à disposição da Sociedade Civil várias formas de controle da atividade administrativa e política (voto); entretanto, a omissão individual em participar do processo político e democrático acarreta a ampliação do arbítrio governamental.

O Controle interno é aquele exercido pela própria Administração na relação de subordinação hierárquica sobre seus próprios atos e agentes, ou por sistema de auditoria que acompanhe seu exercício.

\footnotetext{
${ }^{3}$ CRETELLA JR., José. O Estado e a obrigação de indenizar. Rio de Janeiro: Ed. Forense. 2002. p. 25.

${ }^{4}$ FREITAS, Juarez. Sustentabilidade - Direito ao Futuro, $2^{\mathrm{a}}$ edição, Belo Horizonte: Editora Fórum, 2012. p. 284.
} 
O Controle externo da Administração Pública é feito pelo Parlamento, por intermédio do Tribunal de Contas e pelo Judiciário.

A Emenda Constitucional no 45, que trata da reforma do Poder Judiciário, criou o Conselho Nacional de Justiça - CNJ; entre suas atribuições estão: a elaboração de políticas estratégicas para o Judiciário, a fiscalização da gestão administrativa e financeira dos tribunais e, em caráter suplementar, também as questões disciplinares, controlando a atuação dos juízes. O CNJ é integrado por quinze membros que exercem mandato de dois anos, permitida a recondução.

A mencionada Emenda também criou o Conselho Nacional do Ministério PúblicoCNMP, cujas atribuições são: zelar pela autonomia funcional e administrativa do Ministério Público, receber e conhecer as reclamações contra membros ou órgãos do MP, entre outras. O CNMP é composto por catorze membros, dos quais seis de fora do Ministério Público, com mandato de dois anos, admitindo-se recondução.

Por derradeiro, compartilhamos de opinião no mesmo sentido da corrente doutrinária que defende a aplicação da teoria da responsabilidade objetiva do Estado quando os danos causados, aos administrados, por omissão ou deficiência de atuação estatal, ensejam tal responsabilidade. Em suma: a regra do ordenamento constitucional brasileiro é clara: responsabilidade objetiva do Estado, baseada no risco, independentemente de dolo ou culpa do agente, mesmo para os casos de omissão, levando-se em consideração o dolo ou culpa somente para fins de ação regressiva, propondo a recepção dos princípios da prevenção e da precaução como medidas protetivas e mecanismos para evitar a ocorrência do dano, aliados à observância e utilização efetiva dos instrumentos de controle.

Por fim, trouxemos as referências bibliográficas utilizadas na sua elaboração, composta de boa parte da doutrina nacional, e singela menção da doutrina estrangeira, sem, contudo, cultivar a pretensão de esgotar o estudo sobre o referido tema, mas buscando fornecer subsídios sólidos para aprofundamento dos estudos. 


\section{REFERÊNCIAS BIBLIOGRÁFICAS}

ABBAGNANO, Nicola. Dicionário de Filosofia. São Paulo: Martins Fontes, 2007.

AGAMBEN. Giorgio. Estado de Exceção. Tradução Iraci D. Poleti. São Paulo: Boitempo Editorial, 2007.

ALEXY, Robert. Teoria dos Direitos Fundamentais. Tradução Virgílio Afonso da Silva. 2. ed. São Paulo: Malheiros, 2011.

ARAÚJO, Edmir Netto de. Curso de Direito Administrativo. São Paulo: Saraiva, 2010. O Ilícito Administrativo e seu processo. São Paulo: Revista dos Tribunais, 1994.

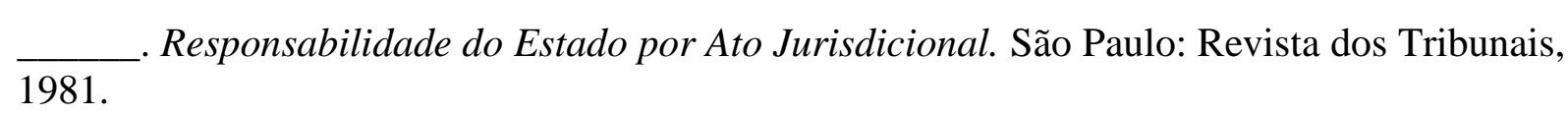

ARISTÓTELES. A Política. Tradução Nestor Silveira Chaves. Coleção Clássicos Edipro. 2. ed. São Paulo: Edipro, 2009.

ARISTÓTELES. Ética à Nicômaco. Tradução Edson Bini. 2. ed. São Paulo: Edipro, 2007.

AZEVEDO, Francisco Ferreira dos Santos. Dicionário Analógico da Língua Portuguesa. 2. ed. revista e atualizada. Rio de Janeiro: Lexikon Editora Digital, 2010.

BANDEIRA DE MELLO, Celso Antonio. Curso de Direito Administrativo. 28. ed. revisada, atualizada e ampliada. São Paulo: Malheiros, 2011.

BANDEIRA DE MELLO, Oswaldo Aranha. Princípios Gerais de Direito Administrativo. 3. ed. São Paulo: Malheiros. 2007.

BARROSO, Luis Roberto. Fundamentos Teóricos e Filosóficos do Novo Direito Constitucional Brasileiro (Pós-Modernidade, Teoria Crítica e Pós-Positivismo). In: BARROSO, Luis Roberto (org.). A Nova Interpretação Constitucional: Ponderação, Direitos Fundamentais e Relações Privadas. 2. ed. Rio de Janeiro: Renovar, 2006.

BAStOS, Celso Ribeiro. Curso de Direito Constitucional. São Paulo: Celso Bastos Ed., 2002.

BEGLEY, Louis. O Caso Dreyfus, Ilha do Diabo, Guantánamo e o pesadelo da história. Tradução Laura Teixeira Motta. São Paulo: Companhia das Letras, 2010.

BITTAR, Carlos Alberto. Revista do Advogado - AASP, no 44. São Paulo, 1994.

BOBBIO, Norberto. O Positivismo Jurídico. São Paulo: Ícone, 1999.

BONAVIDES, Paulo. Do Estado liberal ao Estado social. 6. ed. São Paulo: Malheiros, 1996. 
Teoria do Estado. 2. ed. Rio de Janeiro: Forense, 1980.

. Curso de Direito Constitucional.13. ed. São Paulo: Malheiros, 2003.

BOSSUET. Jacques Bénigne. Politique tirée des propres paroles de l’Ecriture-Sainte. Paris: Chez Pierre Cot, 1709.

BRUNINI, Weida Zancaner. Responsabilidade Extracontratual da Administração Pública. São Paulo: Revista dos Tribunais, 1981.

BÜHRING, Marcia Andrea. Responsabilidade Civil Extracontratual do Estado. São Paulo: Thompson-IOB, 2004.

CADILHA, Carlos Alberto Fernandes. Regime da Responsabilidade Civil Extracontratual do Estado e Demais Entidades Públicas Anotado. Coimbra: Coimbra Editora, 2008.

CAETANO, Marcelo. Manual de Direito Administrativo. 7. ed. Coimbra: Coimbra Editores, 1965.

CAHALI, Yussef Said. Responsabilidade Civil do Estado. 3. ed. São Paulo: Revista dos Tribunais, 2007.

. Dano Moral. 4. ed. São Paulo: Revista dos Tribunais, 2011.

CAMPILONGO, Celso Fernandes. O Direito na Sociedade Complexa. São Paulo: Max Limonad, 2000.

CANOTILHO, J. J. Gomes. Direito constitucional e teoria da constituição. 3. ed. Coimbra: Livr. Almedina, 1999. 1974.

O Problema da Responsabilidade do Estado por Actos Lícitos. Coimbra: Almedina,

CARVALHO FILHO, José dos Santos. Manual de Direito Administrativo. 25. ed. revista, ampliada até a Lei no 12.587, de 3.1.2012. São Paulo: Atlas, 2012.

CAVAlCANTI, Amaro. Responsabilidade Civil do Estado. Rio de Janeiro: Editor Borsoi, 1957. t. 2.

CAVALIERI Filho, Sérgio. Programa de Responsabilidade Civil. 9. ed. revista e ampliada. São Paulo: Atlas, 2010.

CLÉMENT, Zlata Drnas de. El Principio de Precaución Ambiental - La Prática Argentina, Córdoba: Lerner Editora SRL, 2008.

CRETELLA JR., José. O Estado e a obrigação de indenizar. Rio de Janeiro: Forense, 2002. Janeiro, 1970.

Responsabilidade do Estado por atos judiciais. In: Revista Forense, $\mathrm{n}^{\mathbf{o}} 230$, Rio de 
CRETELLA NETO. José. Fundamentos Principiológicos do Processo Civil. Rio de Janeiro: Forense, 2002.

. Direito Processual na Organização Mundial do Comércio- OMC, casuística de interesse para o Brasil. Rio de Janeiro: Forense, 2003.

Direito Internacional do Meio Ambiente. São Paulo: Saraiva, 2012.

DALLARI, Adilson Abreu. A responsabilidade do agente político. In: Jus Navigandi, Teresina, ano 5, n. 42, 1 jun.2000. Disponível em: <http://jus.com.br/revista/texto/354>. Acesso em: 7 jan. 2013.

DALLARI BUCCI, Maria Paula. Direito Administrativo e Políticas Públicas. São Paulo: Saraiva, 2006.

DUEZ, Paul. La Responsabilité de la Puissance Publique. Paris: Dalloz, 2012.

CUNHA, Euclydes da. Os Sertões campanha de Canudos. 39. ed. Rio de Janeiro: Livraria Francisco Alves Editora, Publifolha (Grandes Nomes do Pensamento brasileiro), 2000.

DI PIETRO, Maria Sylvia Zanella. Direito Administrativo. 24. ed. São Paulo: Atlas, 2011.

DIAS, José Aguiar. Da Responsabilidade Civil. 12. ed. Rio de Janeiro: Lumen Juris, 2011.

DINIZ, Maria Helena. Curso de Direito Civil Brasileiro, Responsabilidade Civil. Vol. 7. 19. ed. São Paulo: Saraiva, 2004.

DROMI, Roberto. Derecho Administrativo. 5. ed. Buenos Aires: Ciudad Argentina, 1995.

ENTERRIA, Eduardo Garcia de; FERNANDEZ, Tomás Ramón. Curso de Derecho Administrativo, II. 1. ed. Buenos Aires: La Ley, 2006.

FAGUNDES, M. Seabra. O Controle dos Atos Administrativos pelo Poder Judiciário. 7. ed. Rio de Janeiro: Forense, 2005.

FELICIO, Pedro Eduardo. Brasil X Canadá: histórico de uma crise que poderia ter sido evitada. Disponível em: $\quad$ http://www.fea.unicamp.br/deptos/dta/carnes/files/ Brasil_x_Canada.pdf. Acesso em: 22 dez. 2012.

FERREIRA, Antônio Carlos. Responsabilidade Civil por Atos da Administração Pública. São Paulo: Alfabeto Jurídico, 2002.

FERREIRA FILHO, Manoel Gonçalves. Curso de direito constitucional. 27. ed. atualizada. São Paulo: Saraiva, 2001.

FIGUEIREDO, Lúcia Valle. Responsabilidade dos agentes políticos e dos servidores. In: Revista de Direito Administrativo. Rio de Janeiro, ano 50, n. 196, p. 36-42, abr./jun. 1994.

FIGUEIREDO, Lúcia Valle. Curso de Direito Administrativo. 7. ed. São Paulo: Malheiros, 2004. 
FIGUEIREDO, Marcelo. Probidade Administrativa: comentários à Lei 8.429/92 e Legislação Complementar. 4. ed. São Paulo: Malheiros, 2000.

FRANÇA, Phillip Gil. O Controle da Administração Pública. 2. ed. revista e ampliada. São Paulo: Revista do Tribunais, 2010.

FREITAS, Juarez. Sustentabilidade - Direito ao Futuro. 2. ed. Belo Horizonte: Fórum, 2012.

FUSTEL DE COULANGES. A cidade Antiga. Tradução de Jean Melville. 2. ed. São Paulo: Martin Claret, 2012.

GARCÍA DE ENTERRÍA, Eduardo; FERNÁNDEZ, Tomás-Ramon. Curso de Derecho Administrativo. 10. ed. Madrid: Civitas, 2000. v. 1.

Curso de derecho administrativo. 7. ed. Madrid: Civitas, 2000. v. 2.

GARCIA, Maria. Desobediência Civil. 2. ed. revista e ampliada. São Paulo: Revista dos Tribunais, 2004.

GARCIA, Mônica Nicida. Responsabilidade do Agente Público. 2. ed. revista e ampliada. Belo Horizonte: Fórum, 2007.

GASPARINI, Diógenes. Direito Administrativo. 17. ed. São Paulo: Saraiva, 2012.

GIORDANI, José Acir Lessa. A Responsabilidade Civil Objetiva Genérica no Código Civil de 2002. 2. ed. Rio de Janeiro: Lumen Juris, 2007.

GONÇALVES, Carlos Roberto. Responsabilidade Civil. 13. ed. São Paulo: Saraiva, 2011.

- Direito Civil: Direito das Obrigações: parte especial, volume 6, tomo II: responsabilidade civil. 2. ed. atualizada de acordo com o Novo Código. São Paulo: Saraiva, 2002.

GORDILlO, Agustín. Tratado de Derecho Administrativo. Tomo 2. 5. ed. Buenos Aires: Fundación de Derecho Administrativo. Belo Horizonte: Del Rey, 2003.

HIRONAKA, Giselda Maria F. Novaes. Responsabilidade Pressuposta. Belo Horizonte: Del Rey, 2005.

HOBBES, Thomas. O Leviatã ou A Matéria, Forma e Poder de um Estado Eclesiástico e Civil. São Paulo: Martin Claret, 2010.

O Leviatã ou A Matéria, Forma e Poder de um Estado Eclesiástico e Civil. São Paulo: Martin Claret, 1998.

HOUAISS, Antonio. Dicionário da Língua Portuguesa. Rio de Janeiro: Objetiva, 2001.

HAURIOU, Maurice. Précis de droit administratif et de droit public. 11. ed. Paris: Société Anonyme du Recueil Sirey, 1927. 
IHERING. Rudolf Von. A Luta pelo Direito. Tradução José Cretella Jr. e Agnes Cretella. 5. ed. São Paulo: Revista dos Tribunais, 2008.

JUSTEN FILHO, Marçal. Curso de Direito Administrativo. São Paulo: Saraiva, 2005.

KELSEN, Hans. Teoria Pura do Direito. 2. ed. revista da tradução de J. Cretella Júnior e Agnes Cretella. São Paulo: Revista dos Tribunais, 2002.

KELSEN, Hans. O Problema da Justiça. Tradução de João Batista Machado. São Paulo: Martins Fontes, 2003.

LUIS CARLOS, Lasinha. Erros Judiciários. São Paulo: Ed. São Paulo, Vaner Bígego, 1973. v. 1 .

LAZZARINI, Álvaro. Estudos de Direito Administrativo. 2. ed. São Paulo: Revista dos Tribunais, 1999.

LAUBADÈRE, André de. Traité de Droit Administratif. v.I. 7. ed. Paris: Librairie Générale de Droit et de Jurisprudence, 1976.

LEAL, Roger Stiefelmann. Memória Jurisprudencial: Ministro Orozimbo Nonato. Brasília: Supremo Tribunal Federal, 2007.

LEMOS, Patricia Faga Iglecias. Direito Ambiental Responsabilidade Civil e Proteção ao Meio Ambiente. 2. ed. reformulada e atualizada da obra Responsabilidade Civil por Dano ao Meio Ambiente. São Paulo: Revista dos Tribunais, 2008.

LIMA, Isan Almeida. Do cabimento de recurso extraordinário por violação a princípio. Aplicação do neoconstitucionalismo e neoprocessualismo na teoria dos recursos. In: Jus Navigandi, Teresina, ano 15, n. 2507, 13 maio 2010. Disponível em: <http://jus.com.br/revista/texto/14843>. Acesso em: 9 jan. 2013.

LOBÃO, Marcelo Meireles. Responsabilidade do Estado pela Desconstituição de Contratos Administrativos em Razão de Vícios de Nulidade. São Paulo: Malheiros, 2008.

LOPEZ, Tereza Ancona. Princípio da Precaução e Evolução da Responsabilidade Civil. São Paulo: Quartier Latin, 2010.

MADEIRA, José Maria Pinheiro. Administração Pública. TOMO II. 11.ed. Rio de Janeiro: Elsevier, 2010.

MARANHÃO, Ney Stany Morais. O Fenômeno Pós-Positivista: Considerações Gerais. Disponível em: <http://www.anamatra.org.br/sites/1200/1223/00001573.pdf>. Acesso em: 17 dez. 2012.

MARIENHOFF, Miguel S. Responsabilidad Del Estado por Sus Actos Lícitos, p. 1247-1261. In: Actualidad y Perpectivas Del Derecho Publico a Fines del Siglo XX. V. II. Homenage al Profesor Garrido Falla. Madrid: Editorial Complutense, 1992.

MARTINS JR., Wallace Paiva. Probidade administrativa. São Paulo: Saraiva, 2001. 
MASAGÃO, Mário. Curso de Direito Administrativo. 3. ed. São Paulo: Max Limonad, 1960.

MEDAUAR, Odete. Direito Administrativo Moderno. 16. ed. São Paulo: Revista dos Tribunais, 2012.

MEDAUAR, Odete. Controle da Administração Pública. 2. ed. São Paulo: Revista dos Tribunais, 2012.

MEIRELLES, Hely Lopes. Direito Administrativo Brasileiro. 37. ed., atualizada por Eurico Andrade Azevedo, Décio Balestero Aleixo e José Emmanuel Burle Filho. São Paulo: Malheiros, 2011.

MELO, Olivia Braz Vieira de. O controle jurisdicional do ato administrativo discricionário à luz do princípio da juridicidade. In: Jus Navigandi, Teresina, ano 11, n. 1179, 23 set. 2006. Disponível em: <http://jus.com.br/revista/texto/8955>. Acesso em: 12 jul. 2012.

MENDES JÚNIOR, Onofre. Natureza da responsabilidade administrativa pública. Belo Horizonte: Del Rey, 1951.

MESQUITA, Maria José Rangel de. O Fio da Navalha: (ir)responsabilidade da Administração por fato lícito. In: Cadernos de Justiça Administrativa, nº 46, julho/agosto de 2004, p. 41-54.

MIRANDA, Pontes de. História e Prática do Habeas-Corpus. 7. ed. Rio de Janeiro: Borsoi, 1972.

MODESTO, Paulo. Responsabilidade do Estado pela demora na prestação jurisdicional. In: Revista Diálogo Jurídico, ${ }^{\circ}$ 1, 2001. Disponível em: 〈www.direitopublico.com.br〉. Acesso em: 09 nov. 2019.

MONTESQUIEU, Charles de Secondat, Baron de. Do Espirito das Leis. Tradução Roberto Leal Ferreira. São Paulo: Martin Claret, 2010.

MORAES, Alexandre de. Direito Constitucional Administrativo. São Paulo: Atlas, 2002. Atlas, 2007.

Constituição do Brasil Interpretada e Legislação Constitucional. 7. ed. São Paulo: Direito Constitucional. 27. ed. São Paulo: Atlas, 2011.

Direitos Humanos Fundamentais. 9. ed. São Paulo: Atlas, 2011.

MOREIRA ALVES, José Carlos. Direito Romano. Volume II. 4. ed. Rio de Janeiro: Forense, 1986.

NADER, Paulo. Introdução ao Estudo do Direito. 19. ed. Rio de Janeiro: Forense, 2000.

NOHARA, Irene Patricia. Reforma Administrativa e Burocracia. São Paulo: Atlas. 2012. Direito Administrativo. São Paulo: Atlas, 2011. 
NUNES, Rizzatto. Curso de Direito do Consumidor. 6. ed. São Paulo: Saraiva, 2011.

OLIVEIRA, José Carlos de. Responsabilidade Patrimonial do Estado, Danos decorrentes de Enchentes, Vendavais e Deslizamentos. São Paulo: Edipro, 1995.

OSÓRIO, Fábio Medina. Improbidade administrativa. 2. ed. Porto Alegre: Síntese, 1998.

PANTALEÃO, Juliana F.; MARCOCHI, Marcelo C. Indenização: erro judiciário e prisão indevida. In: Jus Navigandi, Teresina, ano 9, n. 416, 27 ago. 2004. Disponível em: <http://jus.com.br/revista/texto/5642>. Acesso em: 7 jan. 2013.

PEREIRA, Caio Mário da Silva. Responsabilidade Civil - De acordo com a Constituição de 1988. Rio de Janeiro: Forense, 1996.

PINTO. Helena Elias. Responsabilidade Civil do Estado por Omissão - Na Jurisprudência do Supremo Tribunal Federal. Rio de Janeiro: Lúmen Júris, 2008.

BLACKBURN, Simon, A República de Platão: uma biografia. Tradução Roberto Franco Valente. Rio de Janeiro: Jorge Zahar Ed., 2008.

RAMOS, Graciliano. Vidas Secas. 118. ed. Rio de Janeiro: Record, 2012.

RAMOS, Dora Maria de Oliveira. Responsabilidade do Estado por Dano Moral. Disponível em: <www.egov.ufsc.br/portal/sites/default/files/anexos/6856-6855-1-PB.html>. Acesso em: 06 nov. 2012.

REALE, Miguel. Teoria Tridimensional do Direito. 5. ed. São Paulo: Saraiva, 1994.

RIVERO, Jean. Curso de Direito Administrativo Comparado. Tradução de José Cretella Jr. 2. ed. São Paulo: Revista dos Tribunais, 2004.

RIVERO, Jean. WALINE, Jean. Droit Administratif. 18. ed. Paris: Dalloz, 2000.

ROUSSEAU, Jean-Jacques. O Contrato Social. Tradução Pietro Nasseti. São Paulo: Martin Claret, 2004.

SANTOS, Antonio Jeová. Dano Moral Indenizável. 2. ed. São Paulo: LEJUS, 1999.

SÉ, João Sento. Responsabilidade civil do Estado por atos judiciais. São Paulo: Bushatsky, 1976.

SILVA, Alexandre Rezende da. Princípio da legalidade. In: Jus Navigandi, Teresina, ano 8, n. 63, 1 mar. 2003 . Disponível em: 〈http://jus.com.br/revista/texto/3816>. Acesso em: 18 jul. 2012.

SILVA, José Afonso da. Curso de direito constitucional positivo. São Paulo: Malheiros, 1998. 
STERMAN, Sônia. Responsabilidade do Estado. 2. ed. São Paulo: Revista dos Tribunais, 2011.

STOCO, Rui. Tratado de Responsabilidade Civil. 6. ed. São Paulo: Revista dos Tribunais, 2004.

TRUJILLO, Elcio. Responsabilidade do Estado por ato Lícito. São Paulo: LED - Editora do Direito, 1996.

VALIM, Rafael. O Princípio da Segurança Jurídica no Direito Administrativo. São Paulo: Malheiros, 2010.

VEDEL, Georges. Droit Administratif. 5. ed. Paris: Presses Universitaires de France, 1973.

VENOSA, Sílvio Salvo. Direito Civil - Responsabilidade Civil. vol.4. 11. ed. São Paulo: Atlas, 2011.

WALD, Arnoldo. Os Fundamentos da Responsabilidade Civil do Estado. In: Revista de Informação Legislativa, Brasília, ano 30, n 117, jan/mar 1993.

WALINE, Jean. Droit Administratif. 23. ed. Paris: Dalloz, 2010.

WALINE, Marcel. Droit Administratif. 8. ed. Paris: Sirey, 1959.

ZOCKUN, Mauricio. Responsabilidade Patrimonial do Estado. São Paulo: Malheiros, 2010. 